\title{
Locating Zones and Quantify the Submarine Groundwater Discharge into the Eastern Shores of the Dead Sea - Jordan
}

\author{
Dissertation \\ zur Erlangung des Doktorgrades \\ der Mathematisch-Naturwissenschaftlichen Fakultäten \\ der Georg-August-Universität zu Göttingen
}

vorgelegt von

Emad Akawwi

MSc.

Master of science in geotechnical engineering

aus Al Fuhais-Jordanien

Göttingen 2006

Referentin/Referent:

Korreferentin/Korreferent:

Tag der mündlichen Prüfung: $\quad$ 31-07-2006 


\section{Dedication}

\section{To my Parents who supported me and light up my life}

\section{To my brothers}

$\boldsymbol{\alpha}$

To my sisters

\section{Emad}




\section{Abstract}

This study aims to locate the zones of groundwater discharge into the eastern shores of the Dead Sea and to estimate its quantity. The evaluation of inflow was accomplished by different ways of approach: the first one to use the electrical conductivity-temperature with a depth, the second to use a chemical tracer (Radon-222), the third to use thermal infrared imagery and the last is to use electromagnetic radiation techniques in addition to the schematic geological and hydrogeological models of the study area.

The Dead Sea divides into two layers relating to the electrical conductivity and temperature with depth. The upper layer subdivides into two members. The upper member extends from the sea surface down to a depth of $15-25 \mathrm{~m}$. The lower member extends from a depth of $15-25 \mathrm{~m}$ to $40 \mathrm{~m}$ and it characterized with high TDS and low EC. The second layer extends from a depth of $40 \mathrm{~m}$ to the end of profiles. Laboratory experiments carried out to find a relationship between the EC at a specific T and the TDS. These experiments indicate that the EC reachs its maximal $202 \mathrm{mS} / \mathrm{cm}$ at a salinity of about $267 \mathrm{~g} / \mathrm{l}$ from where it starts decreasing with the increase of the TDS and it reachs about $175 \mathrm{mS} / \mathrm{cm}$ at a salinity of $404 \mathrm{~g} / \mathrm{l}$. The minimal of TDS was observed at about $460 \mathrm{~g} / \mathrm{l}$ at EC about $156 \mathrm{mS} / \mathrm{cm}$.

The submarine groundwater discharged into the Dead Sea in the upper $16 \mathrm{~m}$ in Sweimah area. It is discharged in the upper $25 \mathrm{~m}$ in Zarka Ma'in area, in the upper $15 \mathrm{~m}$ in Zara and it is discharged in the upper $18 \mathrm{~m}$ in Mujeb.

The reason why the lower member has the highest TDS was explained. It is due to the very high T at the Dead Sea area in summer and very high evaporation. The density of the upper layer becomes higher than that of the layer underneath. Therefore this denser upper layer sinks beneath the layer which has lower density at the layer where the groundwater discharged into the Dead Sea and this last layer upwelling to the surface.

The chemical tracer radon-222 technique shows that the highest radon concentrations were found at the area close to the shoreline. This means that the largest amount of groundwater discharge is close to the shoreline. As well the highest radon-222 concentrations were found at a depth of $12 \mathrm{~m}$ in the three stations while it was at a depth of $7 \mathrm{~m}$ in the Zarka Ma'in station. It shows also that the groundwater dischargs into the Dead Sea in the upper $20 \mathrm{~m}$. This is coinciding with the finding from the EC and T survey. The submarine groundwater discharge is estimated using Radon-222 as 135.7 million $\mathrm{m}^{3} / \mathrm{y}$ in Sweimah area, about 128.5 million $\mathrm{m}^{3} / \mathrm{y}$ at Zarka Main area, about 33.7 million $\mathrm{m}^{3} / \mathrm{y}$ in Zara area and it is about 90.3 million $\mathrm{m}^{3} / \mathrm{y}$ in Mujeb area. The total quantity of submarine groundwater discharge into the eastern shoreline of the Dead Sea is 388.2 million $\mathrm{m}^{3} / \mathrm{y}$. The quatity of groundwater discharge is estimated by using mixing of TDS about $181 \mathrm{MCM} / \mathrm{y}$, and it is estimated about $59 \mathrm{MCM} / \mathrm{y}$ by using Darcys' law. The results of SGD estimations from different methods compared with the discharge from water balance $480 \mathrm{MCM} / \mathrm{y}$. The results showed that the discharge might be between 200 and $300 \mathrm{MCM} / \mathrm{y}$.

The thermal infrared imagery (TIR) was used to identify thermal anomalies along the eastern shoreline of the Dead Sea, thereby to determine the exact locations of submarine groundwater discharge. As well as, the locations of springs onshore surround the area. Many submarine groundwater discharge zones were identified. The main zones were in Zarka Ma'in, Zara and Mujeb areas. The highest differences in temperature between the groundwater discharge and the sea surface water were observed at the Zarka Ma'in and Zara areas, because these areas have a hot springs flow into the Dead Sea. The TIR imagery showed that the extent of the discharge was between $350 \mathrm{~m}$ and about $750 \mathrm{~m}$ away from the shoreline.

The electromagnetic radiation (EMR) identifies the energy anomalies, thereby determining the active faults and fractures as well as the sinkholes along the eastern shoreline of the Dead Sea. These features are considered zones of weakness for the submarine groundwater discharge. The maximum radiation was observed in Sweimah area. Many major faults and non-opened sinkholes were found along this area at different locations. This proves the finding from chemical tracers that showed that the maximum discharge is in this area. As well few major fault and non-opened sinkholes were observed in Zara-Zarka Ma'in and Mujeb areas.

The geological and hydrogeological models showed that the direction of the groundwater flow is to the west and northwest directions toward the Dead Sea.

Keywords: submarine groundwater discharge, Jordan, Dead Sea, electrical conductivity, thermal infrared, electromagnetic radiation, radon. 


\section{Kurzfassung}

Ziel der vorliegenden Studie war es, die Grundwasser-Austrittszonen entlang des östlichen Randes des Toten Meeres zu lokalisieren und die austretenden Mengen zu bestimmen. Die Studie basiert auf der Anwendung verschiedener Techniken: erstens der Temperatur- und Tiefen-Abhängigkeit der elektrischen Leitfähigkeit; zweitens Verfolgung eines natürlichen chemischen Tracers (Radon 222); drittens thermische Abbildung durch Infrarot-Aufnahmen und letztens der elektromagnetischen Strahlungsmessung. Zusätzlich wurden schematische geologische und hydrogeologische Modelle des Untersuchungsgebietes berücksichtigt.

Der Wasserkörper des Toten Meeres teilt sich in zwei Schichten entsprechend der elektrischen Leitfähigkeit (EC) und dem Temperatur-Verlauf mit der Tiefe. Die obere Schicht wird unterteilt in zwei Glieder. Das obere erstreckt sich von der Wasseroberfläche bis in eine Tiefe von 15 bis $25 \mathrm{~m}$. Das untere Glied reicht von dieser Grenze bis in eine Tiefe von $40 \mathrm{~m}$; es is charakterisiert durch hohen TDS Gehalt und niedrige EC. Die untere Schicht wurde von $40 \mathrm{~m}$ Tiefe bis zur Endtiefe der Beprobung (ca $100 \mathrm{~m}$ ) beobachtet. Laborexperimente wurden ausgeführt, um die Beziehung zwischen EC bei gegebener Temperatur und den ungewöhnlich hohen TDS -Gehalten des Toten Meeres zu bestimmen. Die Experimente zeigen, daß die EC ihren Maximalwert von $202 \mathrm{mS} / \mathrm{cm}$ bei einer Salinität von etwa $267 \mathrm{~g} / \mathrm{l}$ erreicht, von wo aus die EC mit weiter steigendem TDS wieder sinkt und bei 404 $\mathrm{g} / \mathrm{l}$ etwa $175 \mathrm{mS} / \mathrm{cm}$ beträgt. Der niedrigste EC - Wert von $156 \mathrm{mS} / \mathrm{cm}$ wurde bei einem TDS von etwa $460 \mathrm{~g} / \mathrm{l}$ beobachtet.

Im Suweimah - Gebiet strömt das Grundwasser in den oberen $16 \mathrm{~m}$ des Toten Meeres ein. Im Zarka Ma'in - Gebiet geschieht das in den obersten $25 \mathrm{~m}$, und im Mujeb-Gebiet in den oberen $18 \mathrm{~m}$.

Als Grund für den höchsten TDS-Gehalt im unteren Schichtglied der oberen Wasserschicht wird die sehr hohe Evaporation durch sehr hohe SommerTemperaturen am Toten Meer angesehen. Dadurch steigt die Dichte der obersten Wasserschicht über die der darunterliegenden. Darauf sinkt Wasser dieser dichtesten obersten Zone unter die Zone, die auf Grund des einströmenden Grundwassers leichter ist und daher zum Aufsteigen tendiert.

Die Messung des natürlichen Tracers Radon 222 zeigt, daß die höchsten RadonKonzentrationen in Gebieten nahe der Küste vorliegen. Das bedeutet, daß der größte Grundwasserzustrom nahe der Küstenlinie stattfindet. Weiterhin wurden die höchsten Radon-222-Konzentrationen in Zarqa Ma'in in einer Tiefe von $7 \mathrm{~m}$ gefunden, in den übrigen 3 Stationen wurden sie in einer Tiefe von $12 \mathrm{~m}$ beobachtet. Auch das zeigt, daß die Grundwasser-Eintritte in den oberen $20 \mathrm{~m}$ des Toten Meeres liegen in Übereinstimmung mit den EC- und Temperatur-Befunden. Die Menge des eindringenden Grundwassers wurde mit Hilfe des Radon-222 tracers zu 135,7 million $\mathrm{m}^{3} / \mathrm{Jahr}$ für das Suweimah-Gebiet, zu etwa 128,5 Millionen $\mathrm{m}^{3} / \mathrm{Jahr}$ für das Zarqa Ma'in-Gebiet, zu etwa 33,7 Million $\mathrm{m}^{3} / \mathrm{Jahr}$ für das Zara Gebiet und zu etwa 90,3 Million $\mathrm{m}^{3} / \mathrm{Jahr}$ für das Mujeb-Gebiet geschätzt. Die Gesamtmenge des über dei östliche Küstenlinie des Toten Meeres eintretenden Grundwassers beträgt damit 388,2 Millionen $\mathrm{m}^{3} / \mathrm{Jahr}$. Zusaetzlich wurde der 
submarine Grundwasser-Zustrom zu $181 \mathrm{MCM}$ /jahr abgeschaetzt, basierend auf der mischung der TDS- Gehatter, und mittels Darcy's Gesetz ist 57 MCM/jahr. Zusammenfassend liegt der submarine Grundwasser- Zustrom wohl zwischen 200 und $300 \mathrm{MCM} / \mathrm{jahr}$.

Thermische Infrarot-Abbildung (TIR) wurde benutzt, um thermische Anomalien entlang der Ostküste zu identifizieren und so die exakten Grundwassereintritte zu lokalisieren. Das Verfahren zeigt auch die landseitig benachbarten Quellen. Eine Vielzahl von untermeerischen Grundwasseraustrittten wurde identifiziert, wobei die hauptsächlichen Zonen die Zarqa Ma'in - Zara - und Mujeg -Gebiete sind. Die höchsten Temperatur-Differenzen zwischen Grundwasser und Oberflächenwasser des Toten Meeres wurde in Zarqa Ma'in und Zara Gebieten gefunden, da dort heiße Quellwässer in das Tote Meer fließen. Die TIR-Abbildungen zeigen, daß der Grundwassereintritt bis zu zwischen 350 und 750 m von der Küstenlinie entfernt liegt.

Die elektromagnetische Strahlung (EMR) identifiziert durch Energie-Anomalien aktive Störungen und Brüche und auch Lösungshohlräume (Erdfälle) landseitig entlang der Ostküste. Diese Elemente werden als Schwächezonen für die subaquatischen Grundwasserzutritte betrachtet. Die höchste EMR wurde in dem Suweimah- Gebiet beobachtet, wo viele größere Störungen und nichtdurchgebrochene Lösungshohlräume identifiziert wurden. Das unterstützt die Befunde mittels des chemischen Tracers, die die höchsten Grundwasserzutritte in diesem Gebiet anzeigen. Aber auch in den Zara-, Zarqa- und Mujeb-Gebieten wurden einige größere Störungen und nicht- durchgebrochene Lösungshohlräume beobachtet.

Die geologischen und hydrogelogischen Modelle zeigen, daß die Hauptfließrichtung des Grundwassers westwärts und nordwestwärts in Richtung Totes Meer verläuft.

Schüsselworte: untermeerische Grundwasseraustritte, Jordanien, Totes Meer, elektrische Leitfähigkeit, thermische Infrarot-Abbildung, elektromagnetische Starhlung, Radon-222 


\section{Acknowledgements}

The author is highly indebted and expresses his deepest thanks and gratitude to my supervisors; Prof. Dr. M. Sauter (Fakultaet fuer Geowissenschaften und Geographie / Georg-August Universitaet Goettingen), and Prof. Dr. E. Salameh (Faculty of Science / University of Jordan-Amman) for their supervision, helpful suggestions, discussions, their support throughout the progress of this research and for reviewing of this work. This work could not have completed without their helping. I express my thanks to Prof. Dr. E. Salameh also for his helping to get a scholarship to do my PhD.

I would like to express my special thanks to Dr. T. Licha, from the applied geology department in Goettingen University for helping in the chemical laboratory works and his useful discussions. Express my thanks to Dr. J. Wiegand from Wuerzburg University, Dr. F. Kuehn and Ms. I. Gruenberg from BGR for providing with the instruments. Special thanks are also extended to Dr. T. Heinrichs from Goettingen University - applied geology department for his helping and useful discussions during study. Thanks to Prof. Dr. W. Burnett from Florida State University-USA for his help and useful discussions. Thanks also to the colleagues of the hydrogeology group in Goettingen University and to the chemistry technician Mss. Rittmeier M. in laboratory and electrical technician Mr. Fisher S. for their helping.

The author would like to express his thanks to German Ministry of Education and Research (BMBF), Dr. Metzger (PTWT) for funding the research part of study. Thanks also express to Prof. Dr. H. Hoetzl and Dr. W. Ali from Karlsruhe University. Many thanks are attributing to the Katholischer Akademischer Auslaender - Dienst (KAAD) for the financial support for the living expenses during my PhD study.

Sincere appreciate is also extended to Prof. Dr. O. Rimawi president of Al Balqa applied University - Jordan. Thanks going to Dr. A. Al Zouabi, Dr. R. Al-Ruzouq and Msc. A. Abo Al-Adas from Al Balqa Appied University for their helping and assistance.

Thanks are also extended to the colleagues in Natural resources Authority Dr. Z. Hamarneh, geologist R. Masarouh and geologist J. Sahwneh for their help in data collection. Thanks are also extended to geologist. M. Al Moumani and Eng. Abdeldin I. from the ministry of water and irrigation. Special thanks are also due to Mr. Malik Samawi and Mr. Mohmad Samawi for their helping. Thanks to Eng. S. Al showarib, Eng. B. Al zoumout, Eng. J. Amerah, Eng. Z. Halasah and Mr. H. Halasah from Potash Company. Thanks to my friends F. Makdisi, W. Sahwan and M. Al Medanat

Finally I wish to acknowledge and express many thanks to my parents, brothers, sisters and my brother - in - law Eng. Majed Samawi for the moral support and continuous encouragements throughout my study. 


\section{Table of Contents}

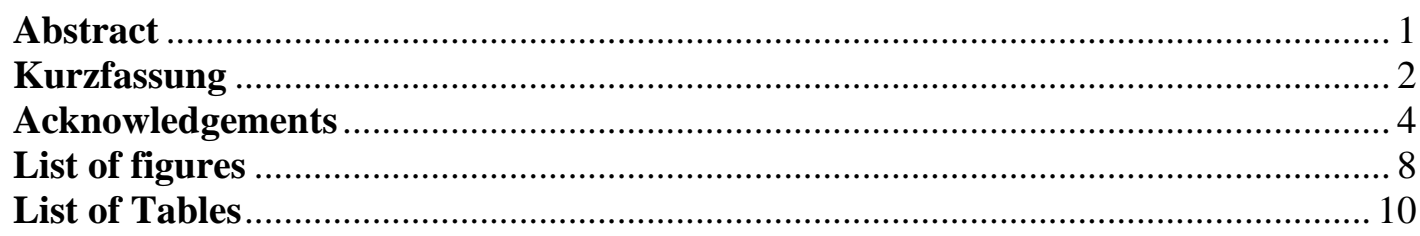

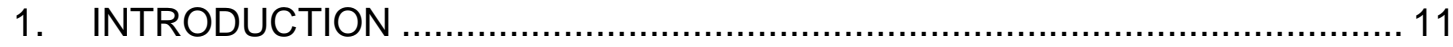

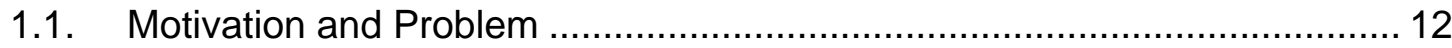

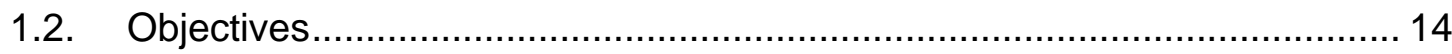

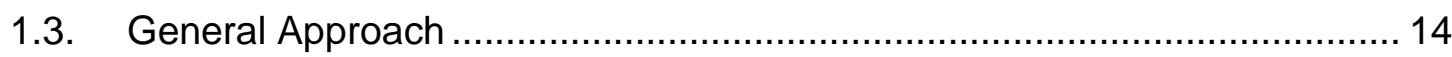

1.4. Concepts of Submarine Groundwater Discharge (SGD) ........................... 16

2. PREVIOUS STUDIES AND BACKGROUND INFORMATION ...................... 18

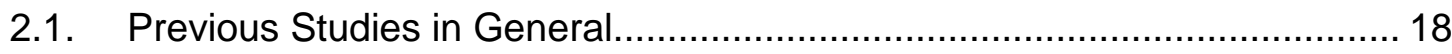

2.1.1. Previous Studies on Chemical Tracers ............................................... 19

2.1.2. Previous Studies on Seepage Meters …………..................................... 22

2.1.3. Previous Studies on Remote Sensing (TIR) ……….......................... 23

2.1.4. Previous Studies on Resistivity and Electrical Conductivity ....................2 25

2.1.5. Previous Studies on Water Budget and Hydrogeological Model ............. 25

2.2. Specific Previous Studies on the Dead Sea ............................................ 26

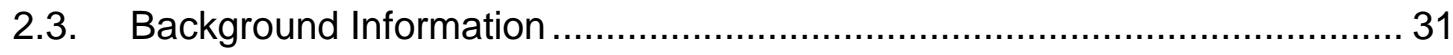

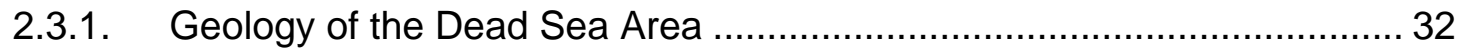

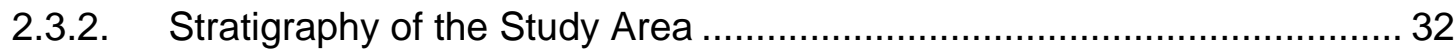

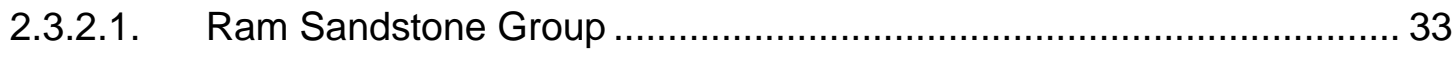

2.3.2.2. Zarka Ma'in Group (MK-MN) …………......................................... 33

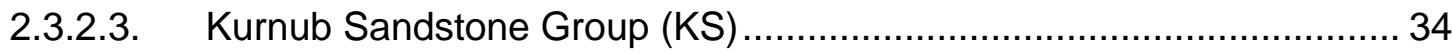




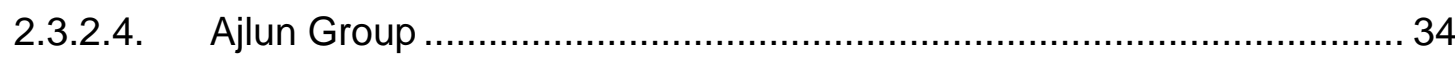

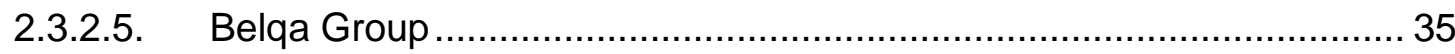

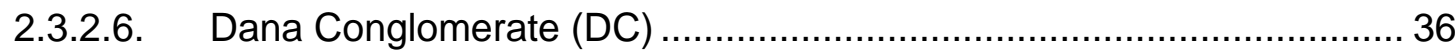

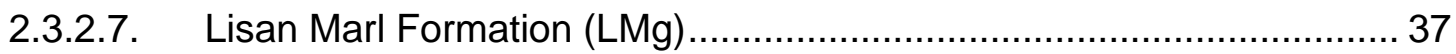

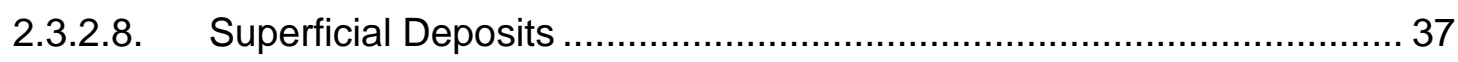

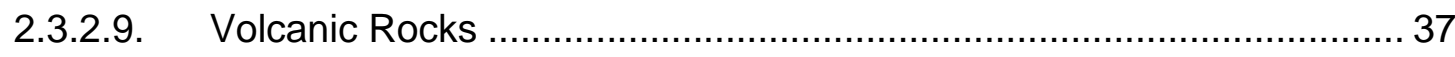

2.3.3. Structural Settings in the Dead Sea Area ……….................................. 39

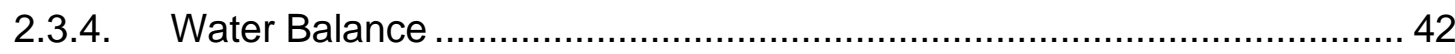

2.3.4.1. Surface Water Flows into the Dead Sea .......................................... 42

2.3.4.2. Groundwater Flow into the Dead Sea............................................... 43

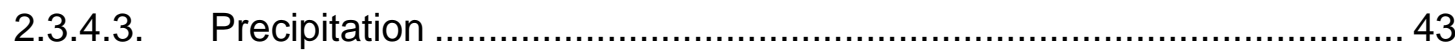

2.3.4.4. Extractions of the Potash Companies ............................................... 43

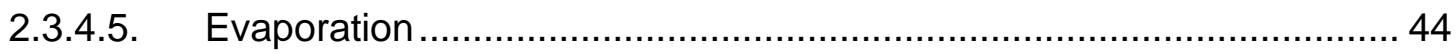

2.3.4.6. Final Balance Calculation ............................................................... 44

2.3.5. Hydrology and Chemical Aspects of the Dead Sea (DS) ........................ 44

2.3.6. Hydrology of Jordan and the Dead Sea Area ....................................... 46

2.3.7. Morphology of the Dead Sea Area ........................................................ 48

2.3.8. Springs Surrounding the Dead Sea.................................................... 49

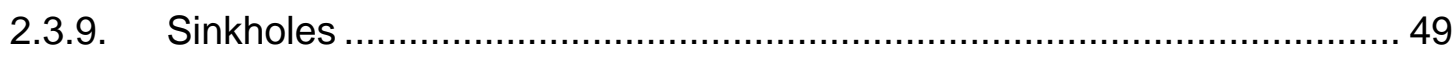

3. METHODOLOGY

3.1. Electrical Conductivity-Temperature with Depth Method.............................51

3.2. Chemical Tracer (Radon-222) Method ………………………................. 54

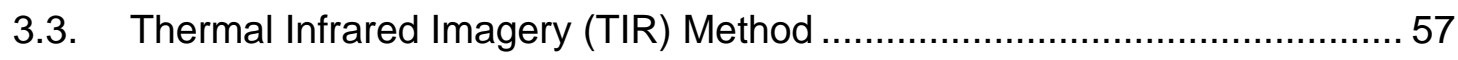

3.4. Electromagnetic Radiation (EMR) Method................................................. 59

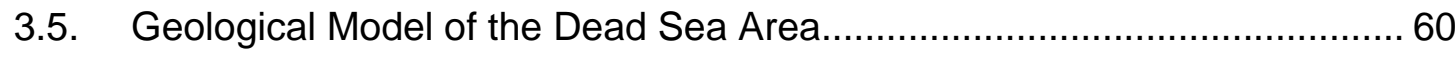




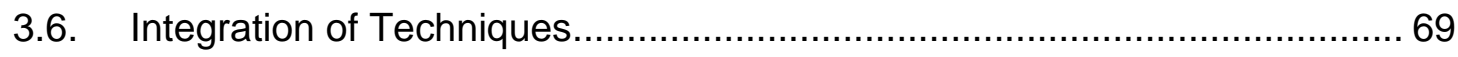

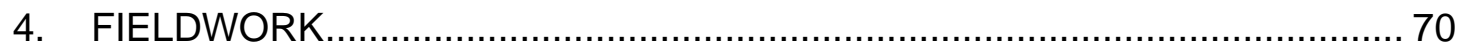

4.1. Electrical Conductivity-Temperature with Depth .........................................70

4.2. Chemical Tracer (Radon-222) ………………....................................... 72

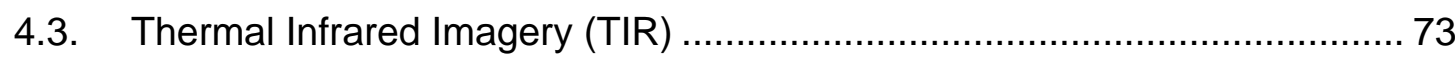

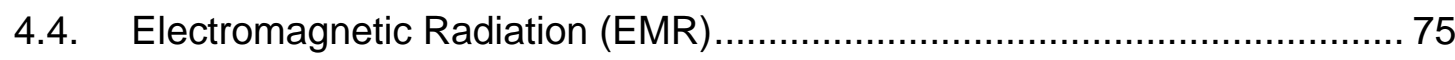

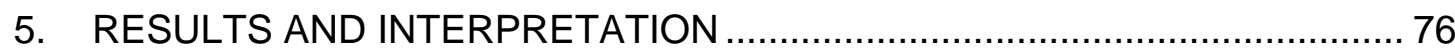

5.1. Electrical Conductivity-Temperature with Depth ......................................... 76

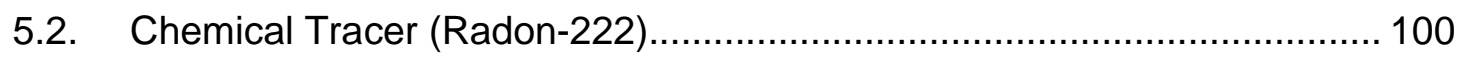

5.2.1. Radon Inventory and Radon Decay ................................................. 107

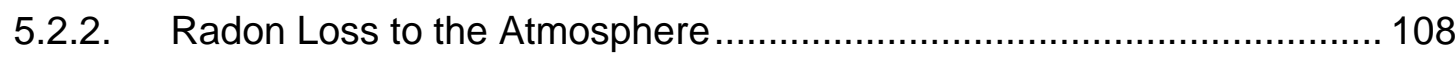

5.2.3. Radon Input via Diffusion from the Sediments .................................... 110

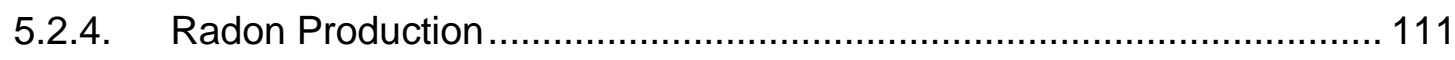

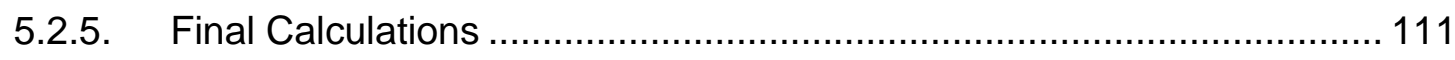

5.2.6. Radon Concentration in the Groundwater and Advection Rate .............. 112

5.3. Estimating SGD by Using Mixing Technique for TDS.............................. 114

5.4. Estimating SGD by Using Darcy's Law.................................................... 116

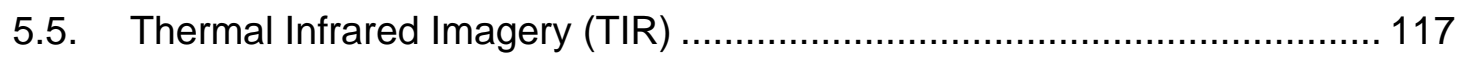

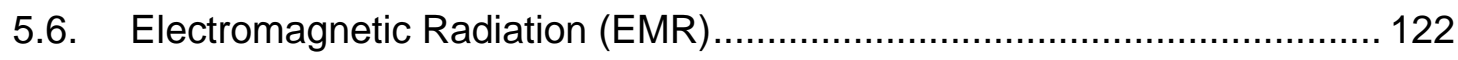

6. HYDROGEOLOGICAL CONCEPTUAL MODEL …..................................... 129

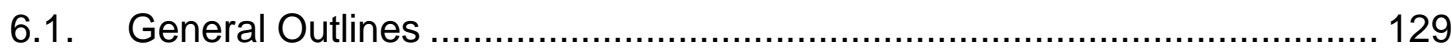

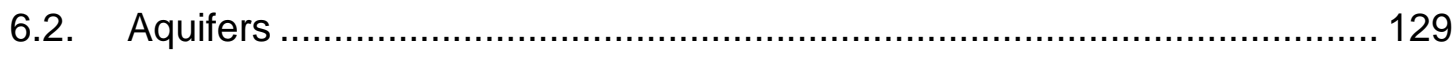

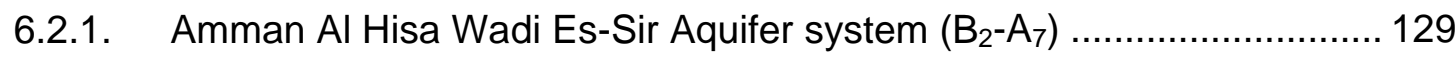

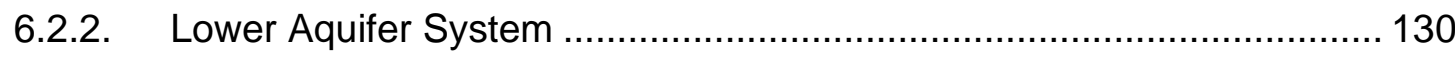

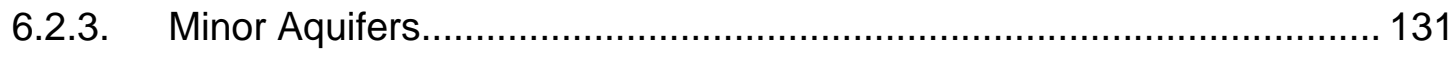


6.3. Aquitards

6.4. Groundwater Movements.

7. SUMMARY and FUTURE PROSPECTS 135

7.1. Summary 135

7.2. Zusammenfassung. 137

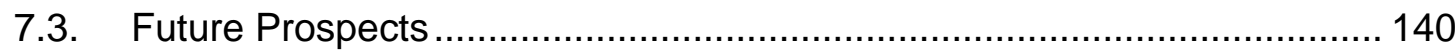

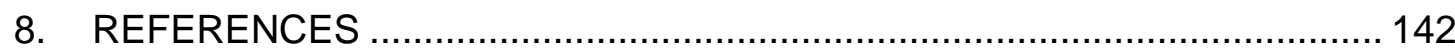

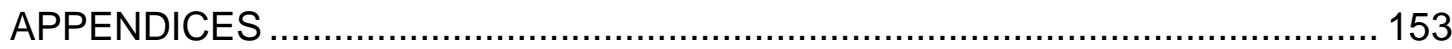

APPENDIX I

\section{List of figures}

Figure-1.1A Location map of the Dead Sea ........................................... 11

Figure-1.1B The study area ............................................................... 11

Figure-1.2 Schematic diagram showing the submarine discharge from seepages and springs.......................................................... 17

Figure-2.1 Schematic diagram showing the relationship between groundwater level and depth of the interface ............................................. 30

Figure-2.2 Simplified geological and structural map of the area surrounding the Dead Sea ......................................................................... 41

Figure-2.3 Long term changes in the surface level of the Dead Sea 1862-2005

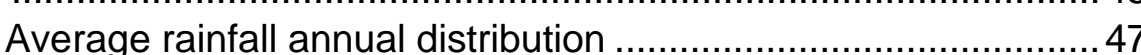

Figure-2.5 Annual average rainfall in percentage ..................................... 48

Figure-2.6 Difference of elevations between Dead Sea and the eastern Highlands ................................................................... 48

Figure-2.7 (A) Schematic geological cross section of springs in Zara area ....... 49

Figure-2.7 (B) Schematic geological cross section of springs in Zarka Ma'in area 49

Figure-2.8 One of the sinkholes located in the Lisan Penensula in eastern coast of the Dead Sea .............................................................50

Figure-3.1 Inductive electrical conductivity sensor with its conections......... 52

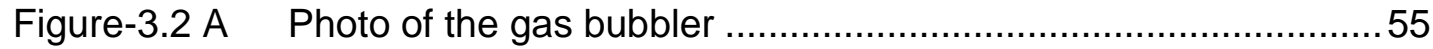

Figure-3.2 B Photo of the RAD7 device ................................................. 55

Figure-3.3 One-dimensional model of sources and losses for ${ }^{222} \mathrm{Rn}$ in a wellmixed coastal environment. 
Figure-3.4

Figure-3.5

Figure-3.6

Figure-3.7

Figure-3.8

Figure-3.9

Figure-3.10

Figure-3.11

Figure-3.12

Figure-3.13

Figure-3.14

Figure-4.1

Figure-5.1

Figure-5.2

Figure-5.3

Figure-5.4 A

Figure-5.4 B.

Figure-5.4 C

Figure-5.4 D

Figure-5.4 E

Figure-5.5 F

Figure-5.5 G

Figure-5.5 $\mathrm{H}$

Figure- $5.5 \mathrm{~J}$

Figure-5.6 K

Figure-5.6 L

Figure-5.6 M

Figure-5.6 N

Figure-5.7

Figure-5.8

Figure-5.9
Settings in ThermaCam Researcher for the flight lines.

Electromagnetic radiation sensor (Cerescope) . 60

Locations of the geological cross-sections exposed on the Geological map. .62

Geological cross section A-A in north Zarka Ma'in fault 63

Geological cross section F-F' located in Sweimah area .............. 63

Geological cross section D-D` located north of Mujeb.................6 64

Geological cross section G-G' located in north Wadi Mujeb....... 65

Geological cross section G-F' crossed Wadi Zarka Ma'in ...........65

Geological cross section M- D`crossed Wadi Mujeb. .66

Geological cross section B-B'-B"'-B"' in Ghor Haditha.

Geological cross section C-C'-C" parallel to the Dead Sea .......68

Thermal infrared flight strips over the Dead Sea.........................74

Relationship between EC and T of the inductive sensor..............76

Relationship between TDS and EC ..........................................78

Comparison between measured and calculated TDS.................8 80

EC, TDS and T relationship with the depth in Sweimah area at a distance of $200 \mathrm{~m}$ from the shoreline.

84

EC, TDS and T relationship in Sweimah area at a distance of 300 $\mathrm{m}$ from the shoreline..... 84

EC, TDS and T relationship in Sweimah area at a distance of 400 $\mathrm{m}$ from the shoreline.

EC, TDS and T relationship in Sweimah area at a distance of 500 $\mathrm{m}$ from the shoreline. 85

EC, TDS and T relationship in Sweimah area at a distance of 800

$\mathrm{m}$ from the shoreline..... 86

Relationship among the EC, TDS and T with the depth in Zarka Ma'in area at a distance $100 \mathrm{~m}$ from the shoreline 89

EC, TDS and T relationship in Zarka Ma'in area at a disatnce 200 $\mathrm{m}$ from the shoreline 89

EC, TDS and T relationship in Zarka Ma'in area at a distance 400 $\mathrm{m}$ from the shoreline 90

EC, TDS and T relationship in Zarka Ma'in area at the distance 800 $\mathrm{m}$ from the shoreline..... 90

EC, TDS and T relationship with the depths in Zara area at a distance of $100 \mathrm{~m}$ from the shoreline 93

$E C$, TDS and T in Zara area at a distance of $300 \mathrm{~m}$ from the shoreline ............................................................................. 93

EC, TDS and T relationship in Zara area at distance of $400 \mathrm{~m}$ from the shoreline 94

EC, TDS and T relationship in Zara area at the distance of $800 \mathrm{~m}$ from the shoreline 94 EC, TDS and T relationship with the depth in Mujeb area at distance of $400 \mathrm{~m}$ from the shoreline .95 Relationship between TDS and densities of the standard salts solution. 99

Sketch diagramfor the zones of discharge along the DS 100 
Figure-5.10

Figure-5.11

Figure-5.12

Figure-5.13

Figure-5.14

Figure-5.15

Figure-5.16

Figure-5.17

Figure-5.18

Figure-5.19A

Figure-5.19B

Figure-5.19C

Figure-5.20

Figure-5.21

Figure-5.22

Figure-5.23

Figure-5.24

Figure-5.25

Figure-6.1

Figure-6.2
Radon-222 distribution with the depth in the main stations 103 Schematic diagrams for EC, TDS and Rn222 showing groundwater flow in Sweimah area. 104 Schematic diagrams for EC, TDS and Rn222 showing groundwater flow in Zarka Ma'in area 104

Schematic diagrams for EC, TDS and Rn222 showing groundwater flow in Zara area 105 Schematic diagrams for EC, TDS and Rn222 showing groundwater flow in Mujeb area 105 Radon-222 concentrations with the depth and distance N-S dirrection 106

Shematic diagram of SGD and the mixing zones...................... 114 Discharge zones along the Dead Sea coast obtained by using TIR Imagery 119

TIR imagery with T scale in Zara (A) and in Mujeb (B) .............. 120

Groundwater flow distribution in Zarka Ma'in indicated by TIR ... 120 Groundwater flow distribution in Zara area indicated by TIR ...... 121

Groundwater flow distribution Mujeb area indicated by TIR....... 122 Locations of the EMR, the EC and Rn-222 stations.................. 123 Magnitudes of the EMR in Sweimah area ................................ 124 Magnitudes of the EMR in south Sweimah area ........................ 125 Magnitudes of EMR in Zara-Zarka Ma'in area .......................... 126 Magnitudes of EMR in Mujeb area .......................................... 127 Spatial locations of the geological assessments, EMR and TIR.. 128 Dead Sea basin showing the outcropping rocks and groundwater directions. 132

Conceptual groundwater model along E-W profile. 134

\section{List of Tables}

Table-2.1 Chronological sequence of the lithological units in the Dead Sea area .................................................................................. 38

Table-3.1 Sybols and coordinates of the geological cross Sections ..........61 61

Table-5.1 Dead Sea water composition during summer 2005 (in $\mathrm{g} / \mathrm{l}$ ) .........77

Table-5.2 Measured and calculated TDS at different depths ...................... 79

Table-5.3 The effect of the salt adding on the EC .................................. 81

Table-5.4 Densities of different TDS values after adding different amounts of

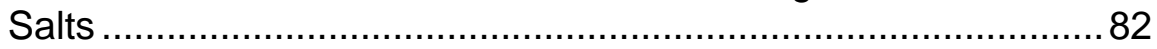

Table-5.5 Radon-222 results of inventory, decay, advection, diffusion and production .................................................................... 112

Table-5.6 Radon-222 concentrations and EC in the springs and seepages Surrounding the Dead Sea .................................................... 113

Table-5.7 The quantities of groundwater discharge estimating from different methods ......................................................................... 117

Table-5.8 Coordinates of some of the discharge zones along the eastern shores of the Dead Sea. 


\section{INTRODUCTION}

The Dead Sea is a hypersaline terminal lake with a surface area in 2004 is approximately $634 \mathrm{~km}^{2}$ and its border is approximately $148 \mathrm{~km}$ (Rishmawi et al. 2005). It located in the central part of the Jordan Rift Valley, which extends from Lake Tiberias in the north to the Gulf of Aqaba at the south, and includes the Jordan River in the north, the Dead Sea region in the middle and the southern Ghors (Haditha, Mazra, Safi), Wadi Araba and the Gulf of Aqaba in the south. Geologically, the Dead Sea "lake" is situated within the large Dead Sea basin, which is one of the pullapart basins that formed along the Dead Sea Rift (Quennell, 1959) and it is located in the southern sector of the Dead Sea Transform (DST), which separates the arabian and African plates (Capaccioni et al. 2003) as shown in (Fig. 1-1A). The Dead Sea can be traced in terms of plate tectonics to the movement of the great plates into which the lithosphere is divided (Steinhorn and Gat, 1983). The Dead Sea is subdivided into two basins, the southern shallow basin, and the deep northern basin. The investigated area covers the eastern coast of the Dead Sea region, which extends from northern part of the Dead Sea in Sweimah to the southern part of the Dead Sea in Ghor Haditha (Fig.1-1B). This study is trying to find the answering for the questions: How much is the quantity of the groundwater discharge into the Dead Sea? Where are the discharge zones located?
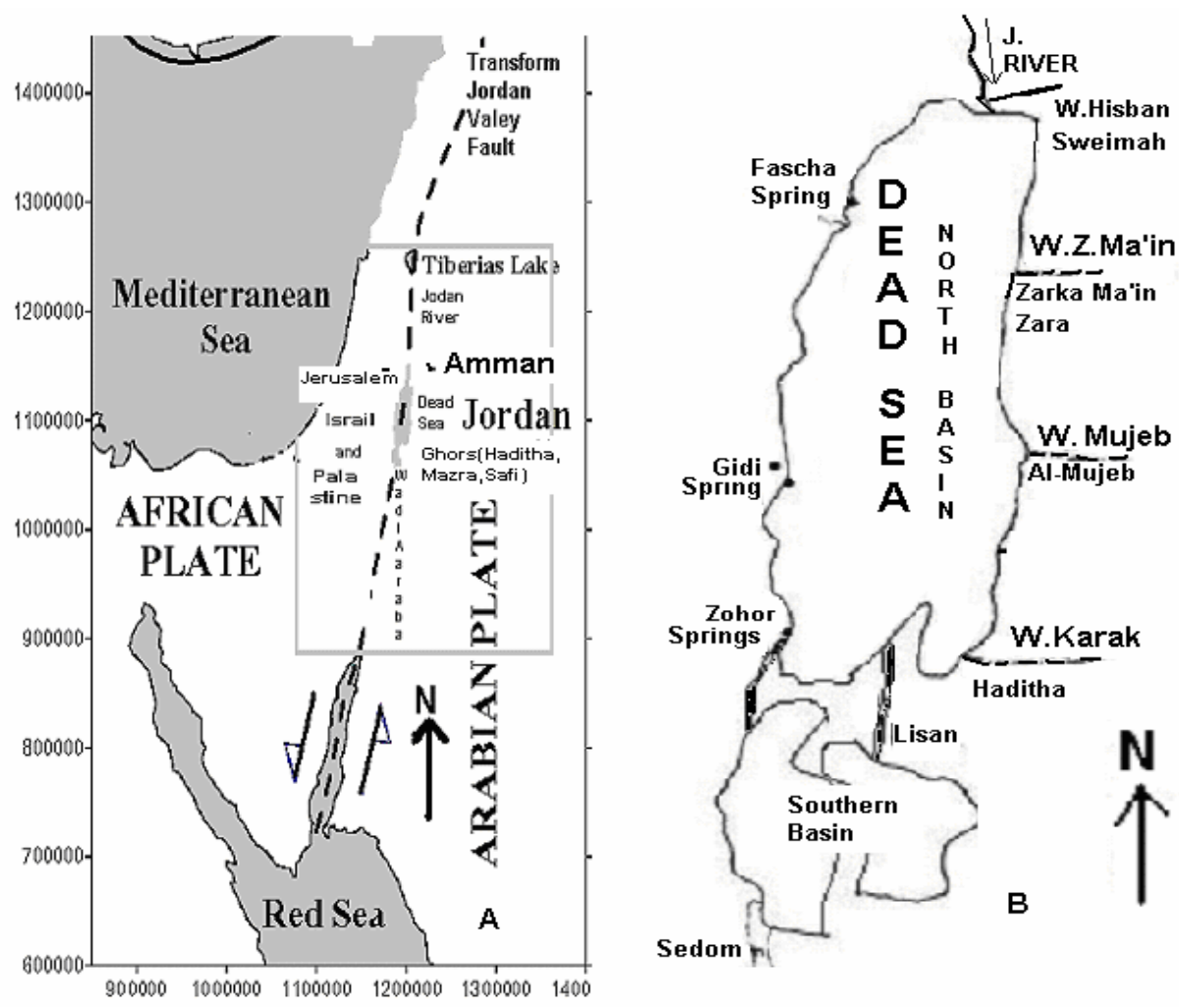

Figure (1-1): A: Location map of the Dead Sea, B: The study area. 


\subsection{Motivation and Problem}

Jordan is one of the Middle East Countries. It located in arid and semi arid climatic zones. Only the highlands, with a width about $30 \mathrm{~km}$ and a length of about $300 \mathrm{~km}$ are considered as of Mediterranean climate. As water is considered to be one of the most important resources, so its presence is essential for achieving the overall economic and social development in the country.

Jordan is water stressed country and lacks for enough water resources. Therefore the deficit in the water supply was estimated at $238 \mathrm{MCM}$ in 2005. This deficit is expected to rise to about $408 \mathrm{MCM}$ in the year of 2020. This is because of the water demand in the country is much higher than the water supply (i.e. the water supply don't satisfy the country needs) from which emerge areal problem must be solved.

Groundwater is considered to be the major water resources for many regions, and the only resource in other regions-in Jordan. It supplies more than $80 \%$ of the total quantity of water in the Jordanian areas and plays an important role in urban industrial and agricultural water supply. High and continually increasing demands for groundwater for domestic, industrial and agricultural and other needs due to high population growth rates (around 2.9\%/year), the continual upgrading in living standard and the existing degradation in groundwater quality because of pollution and salinization are putting more pressure on the groundwater resources of the country. Therefore the groundwater management and planing are required. Concluding that, the groundwater is a valuable and an important natural resource in Jordan. So the priority of all strategies is to preserve water quatity and purity to use clear fresh water.

Groundwater is the major source of fresh water in the Dead Sea region which issuing from the surrounding highlands. The high demand for fresh water occurred in the Dead Sea area due to the major industries established at the area as Potash Company and other sub-companies, and the irrigation.

However the countries (Jordan, Syria, Palestine and Israel) controlling the fresh watershed of the Dead Sea. They began to consume these waters intensively (Salameh and Khawaj, 1984). As well Israel and Jordan are using the Dead Sea water for potash and other minerals production, which contributes to the depletion of water (Gavrieli, 1997). Also the evaporation from the Dead Sea exceede the rain and runoff into it. As a result, the inflow of fresh waters into the Dead Sea has diminished significantly.

This drop of the Dead Sea level will have an effect on groundwater by increasing the head differences between the Dead Sea and the groundwater levels in the surrounding areas. Then the groundwater drainage is expected to increase toward the Dead Sea (Salameh and Khawej, 1984, Yechieli et al., 1996, Salameh and ElNasir 2000a,). The decline in the Dead Sea level also accelerates the discharge of 
groundwater into the Dead Sea (Salameh \& Naser 1999, 2000b). Around 423 MCM of the groundwater discharge to the Dead Sea for every meter drop in the level of the Dead Sea for the period between 1994 and 1998. This amount of fresh water discharging to the Dead Sea decreased to $370 \mathrm{MCM}$ in 2000 as a result of exploitation mismanagement of water, which formerly fed the Dead Sea. The area underlying the coastal aquifers already occupy by the Dead Sea water. They become gradually flushed and occupied by freshwater. This freshwater become saline due to the residuals of the Dead Sea water in the aquifer matrix (Salameh and El-Nasser, 2000b).

The shoreline of the Dead Sea also has retreated during the last four decades by an average of $2 \mathrm{Km}$. The newly exposed shoreline along the eastern side of the DS has not been studied with respect to hydrogeology and hydrochemistry. Their water resources altogether with the older coast resources are not yet understood.

A large parts of the Dead Sea area characterize as a highly karstic and fractured rock formations that are genetically connected with faults and karstic routes extending from the land into the sea, and the prevailing seaward-sloping rock strata. A steep escarpment along the Eastern shoreline of the Dead Sea controls the morphology of the Dead Sea area. The difference in the elevation between the Dead Sea level and the highlands to the East is more than $1210 \mathrm{~m}$ over a horizontal distance of $15 \mathrm{~km}$. These might be a reason for the submarine groundwater discharge (SGD) into the Dead Sea. The quantity of freshwater input into the Dead Sea occurred due to surface water runoff in winter season or due to submarine groundwater discharge.

The drop of Dead Sea level is accompanied by a retreat of the shoreline and in reduction in the size of the surface area, accompanied by change in the location of existing springs, and in the appearance of new springs along shoreline. Then its need to understand and evaluate newly exposed of the eastern shoreline along the the Dead Sea in respect of hydrogeology.

Several subsidence and sinkholes (i.e. circular depressions in a karst area of subterranean drainage) rose in the cultivated area of Ghor Haditha and Lisan Penesula in the end southern part of the Dead Sea. Due to inflow of the fresh groundwater into the Dead Sea, These phenomena cause a serious danger to residences and farmers at these areas. It may be possible to reduce the scale of these subsidence by reduce the rate of dissolution of the layer by removing the waters undersaturated with respect to salt or by controuling the groundwater discharge into the Dead Sea. 


\subsection{Objectives}

This study expected to assist several major objectives in terms of the submarine groundwater discharge, which are very useful for controlling the discharge to the Dead Sea and they are related to the problems mentioned above.

1- To locate and evaluate the areas of submarine ground-water discharge along the eastern coast of the Dead Sea.

2- To test the ability of the electrical conductivity and temperature techniques for delineating the fresh water flow into very high saline Dead Sea water.

3- To establish a quantitative relationship between the flow of submarine groundwater discharge and the inventory of water column radon-222 and then estimating the quantity of the groundwater discharges into the eastern shoreline of the Dead Sea.

4- To investigate and evaluate if method of thermal infrared imagery data collection and analyses have the potential for detecting groundwater discharge to the Dead Sea.

5- To develop a geological model of the study area

6- To scheme a conceptual hydro-geological model of the studied area that describes the groundwater horizontal and vertical movements.

7- To determine the availability of exploitable water resources that can be abstracted to assist in the water supply along the shores of the Dead Sea in order to provide the basis for future development e.g. tourism in that unique geologic area.

\subsection{General Approach}

An appropriate approach and procedures were followed in order to examine groundwater discharge into the Dead Sea and to achieve the other objectives related to this study.

The geological and topographic map sheets of scale 1:50,000 that cover the investigated area were collected. These maps sheets are the southern part of Karameh, Ma'in and Ar-Rabba. The wadies and the main faults were defined by using these maps. These faults and wadies were used as prospective indicators for the submarine groundwater discharge locations as springs, seepages and other points of discharges in the investigated area. Also different geological cross- 
sections were constructed by using these maps. Then a geological model for the study area was created depending on these geological cross-sections.

The methods and techniques for localizing and quantifying the submarine groundwater discharge (SGD) were determined in relation to the temperature, the salinity, and other geochemical fingerprints of the seawater and fresh water.

Due to the highly contrast of the salinity and the electrical conductivity between the sea water and fresh water the electrical conductivity was selected to locate the submarine groundwater discharge into the Dead Sea. An inductive (electrodeless) electrical conductivity device type 871EC-BW sensor manufactured by Invensys FOXBORO was used for carrying out the electrical conductivity, temperature measurements. Because of the electrode sensor is not suitable for the very high saline Dead Sea water (more than $340 \mathrm{~g} / \mathrm{l}$ ). The sensor was calibrated relating to temperature compensation at $25^{\circ} \mathrm{C}$.

The other technique that used for quantifying submarine groundwater discharge into the Dead Sea is the chemical tracer technique (Radon-222).

The chemical tracer Radon-222 $\left({ }^{222} \mathrm{Rn}\right)$ was chosen as one of techniques for quantifying a submarine groundwater discharge into the Dead Sea, because it is 34 orders of magnitude more concentrated in groundwater than that typical surface water and seawater, and the half-life decay rate is known and short (3.82 day). RAD7 radon device manufactured by (Durridge Co. Inc.) was used for analyzing the ${ }^{222} \mathrm{Rn}$ samples. An under sea surface soils samples were collected and analyzed for determining the radon diffusion from the sediments. As well samples from the springs and seepages surrounding the Dead Sea were collected and analyzed by using the same device. After one month the sea samples were analysed again for determining the radon ingrowths. As well the porosity and wet bulk density of the Dead Sea sediments were determined. The electrical conductivity and radon-222 measurements were carried out between July and August-2005 by using small engine boat.

The promising places for the electrical conductivity and radon-222 measurements and sampling were determined using the geological maps and field investigations according to the lithological and geological formations of the Dead Sea area, and the distribution of the springs and seepages.

The other technique is the thermal infrared (TIR) imagery. It was used in this study in order to delineate the zones of submarine groundwater discharge occurring at the eastern coast of the Dead Sea. This method of the thermal fingerprint is based on a pronounced thermal gradient between the groundwater and ambient surface conditions. The thermal infrared images were carried out in the end of December 2005 using a small commercial plane with the assistance of the Federal Geological Survey of Germany (BGR). The plane was developed especially for this purpose. The thermal infrared camera (FLIR System 8-13 $\mu \mathrm{m}$ ) was fixed at the bottom of the 
plane (Appendix I) after calibrating relating the air temperature and the humidity for the area. The plane with a camera was flight over the eastern coast of the Dead Sea and the over the Dead Sea itself. The images were taken from an elevation between 1300 and 1600 meter above standard sea level. The flight direction was from the south to the north and vice versa. The length of each strip was about 25 $\mathrm{km}$ of the eastern coast of the Dead Sea. Four strips were carried out with different coordinates. GPS data were taken by using fixed GPS stations. One GPS station was fixed inside the plane and the other station in the ground at the airport.

The electromagnetic radiation (EMR) is the other technique was used in this study. The principle of this method is the energy release from the fault and fractured activities. This method was used to localise the active faults, fractured zones and the non-opened sinkholes along the Dead Sea shoreline. These are considered as zones of weakness of the groundwater discharge at the Dead Sea area.

The data that used for estimating the groundwater discharge into the Dead Sea by using the water budget technique were collected from the previous study of (Salameh and El-Naser, 1999). This result was compared with the results that were obtained by using the chemical tracers $\left({ }^{222} \mathrm{Rn}\right)$ technique.

Finally a hydrogeological conceptual model for the groundwater movement in the study area was developed based on the geological maps, the geological model, the structural patterns and the aquifers properties in the study area.

\subsection{Concepts of Submarine Groundwater Discharge (SGD)}

The direct discharge of groundwater into the coastal zone has received increased attention in the last few years as it is now recognized that this process may represent a potentially important pathway for material transport. Understanding SGD is important for both a component of the general water cycle and potential resource as well as to coastal environmental management where undesirable contaminants in groundwater can be discharged into the near-shore marine environment. Generally almost all coastal zones are subject to flow of groundwater either as submarine springs or propagated seepage. The same can be happened in some deep aquifer if has fractures or other breaches in the overlying, confining layers, allowing groundwater to flow into the sea. The groundwater might flow directly to the sea wherever a coastal aquifer is connected to the sea. In addition to fresh groundwater from land, also the re-circulated seawater is driven through bottom sediments by a number of processes might discharge into the sea (Fig. 12).

The groundwater seepage near shorelines comes out from hydraulic gradients on land and this seepage may contribute to flow further out on the shelf from confined aquifers (Burnett et al. 2003). In other words groundwater may enter coastal 
surface waters as dispersive seepage along shorelines, as point source seepage due to a breach in the confining layer of an underlying aquifer, and as spring discharge (Moore, 1999). However Groundwater will seep into the marine environment along any coastline where the water table and underlying aquifers slope toward the sea or when weaknesses in confining layers generate springs. Submarine groundwater discharge (SGD) in general occurs everywhere through permeable sediments where the hydraulic head of aquifers is above sea level, and sometimes includes a re-circulated seawater component (Burnett et al. 2001, Charette et al. 2003).

As a result aquifers lose or gain water to lakes, streams and coastal waters by several natural mechanisms set up by the hydraulic gradient between the aquifer and these standing bodies of water (Cable et al. 1997). Changes in groundwater discharge from an aquifer can vary overtime periods. The rapid fluctuations in groundwater seepage might occur over time due to changes in lake level and barometric pressure (McBride and Pfannkuch, 1975).

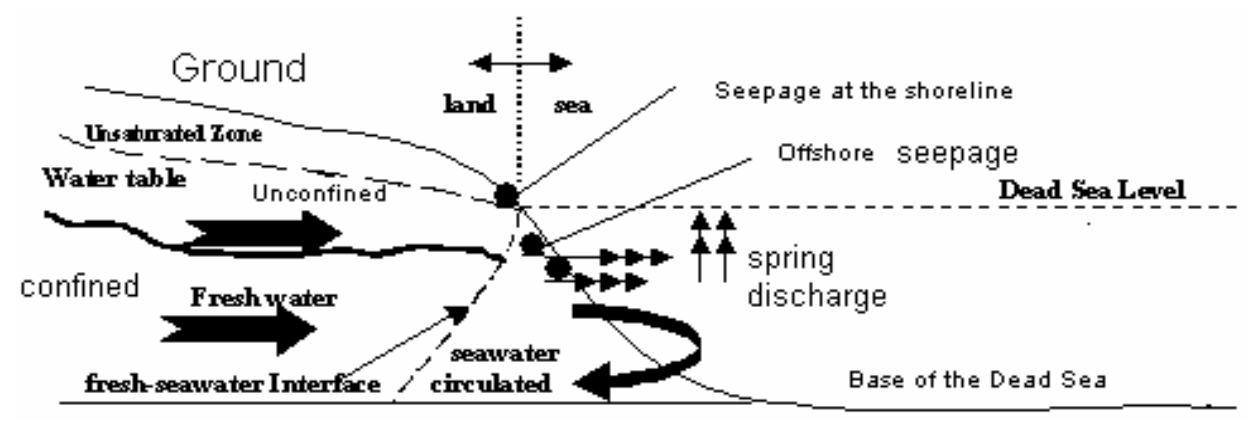

Figure (1-2): Schematic diagram showing the submarine discharge from seepages and springs.

The term SGD has been used in different ways over the years. Zektser et al. (1983) defined SGD to be the net groundwater discharge to the ocean, which comes essentially from recharge. Church (1996) defined SGD to be direct groundwater outflow across the ocean-land interface into the ocean, which would include re-circulated seawater. Li et al. (1999) Considered SGD to be the sum of net groundwater discharge, outflow due to wave-setup-induced groundwater circulation, and outflow due to tidal driven oscillating flow.

Total water, in the coastal environment, discharge into the ocean consists of surface water discharge and SGD. Submarine pore water exchange occurs across the seabed by SGD and submarine groundwater recharge. The water depth, the groundwater hydraulics and the geometry of the flow domain are the main parameters for controlling submarine groundwater discharge 
There are three measurement units applied commonly to SGD: (1) volume per unit time $\left(\mathrm{m}^{3}\right.$ day $\left.^{-1}, 1 \mathrm{~s}^{-1}\right)$; (2) volume per unit time per unit length of shoreline $\left(\mathrm{m}^{3}\right.$ day $^{-1}$ (m shoreline $)^{-1}, \mathrm{~m}^{3}$ year $\left.^{-1}(\mathrm{~km} \text { shoreline })^{-1}\right)$; and (3) volume per unit time per unit area which is Darcy's flux $\left(\mathrm{cm}^{3} \mathrm{~cm}^{-2} \mathrm{~s}^{-1}, \mathrm{~cm} \mathrm{~s}^{-1}, \mathrm{~m}_{\text {year }}{ }^{-1}\right)$ (Taniguchi et al. 2002).

\section{PREVIOUS STUDIES AND BACKGROUND INFORMATION}

\subsection{Previous Studies in General}

Despite its importance, Submarine groundwater discharge (SGD) remains difficult in most places because it is diffuse and miscellaneous and occurs below the ground surface usually unseen and the measurement and direct observation are difficult (Bokuniewicz et al. 2003, Crusius et al. 2005). SGD has been measured at only about a hundred sites worldwide and most of them are along the east coast of the United States, Europe, around Mediterranean Sea and in Japan (Taniguchi et al. 2002). Fewer studies have been done on the west coast of the United State of America and Hawaii, and wide areas of the world as South America, Africa, and southern Asia have little to no SGD assessments at all.

SGD may affect both water quality and biogeochemical cyclic (Capone and Bautista, 1985).

SGD can be estimated by several geological and hydro-geological methods. These methods are divided into two groups: methods based on investigation of the coastal drainage area (hydrodynamic, combined hydro-geological, average longterm water balance method, modelling of groundwater discharge method), and methods based on hydro-geological investigation of the estuary as (remotesensing method, geophysical methods, measurement of anomalies of sea water electrical conductivity, temperature distribution, and chemical composition) (Mulligan and Charette, 2006).

The following are some of these methods: -

Geochemical tracers techniques investigate excesses of the tracers Radium isotopes (Ra-226, 228, 223 and Ra-224), Radon (Rn-222, 220), Methane (CH4), Hydrogen $(\mathrm{H} 3)$, Helium $\left(\mathrm{He} 3, \mathrm{He}_{4}\right)$, Carbon $\left(\mathrm{C1}_{4}\right)$ (Moore, 2003). The present of the above isotopes with high concentrations in the open water are often indicative of groundwater sources.

Seepage meters (flow chambers vented to plastic bags accompanied by volume and salinity measurements), or ultrasonic seepage meters. 
Geophysical/Hydrology, salinity, and conductivity. If the discharges of freshwater are great enough, the depression of salinity in the overlying water alone may pinpoint the source of SGD.

By using airborne thermal infrared imaging 'characterize groundwater surface water interactions between the sea and the shallow aquifers. It based in measurable physics parameters such as sea surface temperature

Can be calculated directly in terrestrial water budgets (water balance), hydro-geological model.

As well total SGD might be calculated by using piezo-meters and application of Darcy's law at a particular spot if the vertical hydraulic gradient is measured of the sediment-water interface along with measurements of the vertical permeability of the sediments.

Or can be determined also by using mathematical models, either analytical or numerical techniques.

The difficulty of quantifying SGD is because of the methods are often indirect and pressing a many of assumptions (Oberdorfer, 2003).

\subsubsection{Previous Studies on Chemical Tracers}

Several studies have employed to use the natural uranium decay-series nuclide (Chemical Tracers) Ra-226 and Rn-222 as well as Methane to estimate and evaluate groundwater inputs to the Seas.

Radium isotopes as tracers were reporting on the quantity and effects of SGD off the coast of southeastern U.S. (Moore, 1984, Moore, et al. 1985, Moore, 1996; Rama and Moore 1996; Moore and Shaw, 1998, Moore, 2000, Moore, 2003). Radium isotopes were used by (Krest and Harvey, 2003, Charette et al. 2001; Kelly and Moran, 2002; Charette et al. 2003) in order to study SGD and coastal residence times. Radon-222 was used by scientist such as (Burnett et al. 1996;Cable et al. 1996b; Burnett et al. 2001; Burnett et al., 2002; Lambert and Burnett, 2003; Burnet and Dulaiova, 2003) to investigate SGD into the Gulf of Mexico in U.S.A. (Chanton et al. 2003; Corbett et al. 1997; Corbett et al. 1999, Corbett et al. 2000) used radon-222 in Florida Bay.

Methane was used for investigating groundwater input into the Gulf of Mexico (Bugna et al. 1996), in Florida Bay (Corbett et al., 1999; Schwartz, 2003), in West Neck Bay, U.S.A. (Dulaiova et al. 2004) and in Korea (Kim and Hwang, 2002). 
According to D'Elia et al. (1981) many researchers have recognized the biogeochemical importance of groundwater discharge through coastal sediments. Such fluids may be an important source of nutrients for the coral reefs

Cable et al. (1996b) used the radon-222 as grab sample to estimate the submarine groundwater discharge into the Gulf of Mexico. They constructed a mass balance for Rn-222 for one layer. They did not intrest with the radon transport to or from adjacent coast areas under normal flow conditions.

Corbett et al. (1997) used the standard hydrologic budget in addition to natural tracer (Rn-222) approach for estimating groundwater input. The results show that helping to constrain estimated groundwater flow into surface reservoirs.

Corbet et al. (1999) used radon-222 and methane $(\mathrm{CH} 4)$ to evaluate the patterns and assessment of groundwater discharge. They used a grab samples method, and the samples were collected both from the wells and from the seawater. They obtained good comparative results between two methods.

Burnett et al. (2001) Burnett and Dulaiova (2003); Lambert and Burnett (2003) used the continuous monitor of Radon-222 for estimating the groundwater input into the coastal ocean. They demonstrated an automated system that can determine the radon activity in coastal ocean water. They used the RAD7 device for the radon-in-air monitor because it is very sensitive.

Swarzenski et al. (2001) investigated the fluxes of radium in order to estimate the submarine groundwater discharge to the Indian River Lagoon. They used three independent methods (lagoon budget, benthic flux chamber, and pore-water modelling).

Taniguchi et al. (2002) used the term SGD to represent the direct discharge of subsurface fluids across the land-ocean interface (i.e. SGD rate is the sum of submarine fresh groundwater discharge and the re-circulated saline groundwater discharge). They made the comparison between the SGD and water depth. They found that the discharge estimates tend to decrease fairly systematically with increasing water depth over about three orders of magnitude.

Lambert and Burnett (2003) found that the comparison between the submarine groundwater measurements using grab sampling and the continuous monitor shows excellent agreement and there are few samples not in agreements due to handling, loss of radon during sampling, or analysis of the grab samples.

Schwartz (2003) used and assessed a multiple radon fluxes to determine the source of the Torally persistent and spatially fixed the excess radon at a maximum value. The assessed radon fluxes included diffusive input for sediment, surface water advection, air-sea evasion, groundwater input, and radioactive decay of radon 
Abraham et al. (2003) attend to overcome the limitations of poor understanding of the distribution of radium and radon isotopes in coastal groundwater. They mapped the distribution of Rn-222 and Ra-226 across a groundwater salinity gradient, and deployed a new in situ Rn-222 analyzer to study time dependence of SGD in Waquoit Bay. They used a drive-point piezometer, in order to collect four depth profiles of groundwater Ra-226 and Rn-222 along a transect perpendicular to the shore at the head of Waquoit Bay. They created a vertical section of each isotope at the groundwater-seawater interface. According to Abraham et al. (2003) Rn-222 displayed an increase in activity with increasing salinity, depth and distance from the beach. The distribution of Rn-222 throughout the aquifer should be uniform, and not affected by changes in salinity, because Rn-222 is a noble gas. They quantify SGD to Waquoit Bay applying a non-steady-state mass balance model to them time series Rn-222 record which collected over 3 days at the head of the Bay.

Burnett and Dulaiova (2003) compared the results of the ground water discharge, which they obtained by using the continuous measurement of radon-222 for estimating groundwater discharge into the coastal zone with results of other studies in the same area using methods such as radium isotopes (Ra-223, Ra224), and the automated seepage meters. They found that the results were comparable for the three approaches in the august readings. But in October the radon measurements indicate similar but slightly higher rates of flow than those calculated from the automated seepage meter. The estimate based on radium isotopes indicates a flow about a factor of two greater.

Charette et al. (2001) measured the activities of radium isotopes (Ra-223, Ra-224, Ra-226, and Ra-228) to estimate the submarine groundwater discharge. They compared the data, which they obtained with the other, which obtained from previous years. Then they estimate the groundwater discharge by calculating the excess radium flux in the sea.

Charette et al. (2003) made an interpretation of two decades of unique set of radium isotopes data spanning in order to quantify submarine groundwater discharge in Great Sppewissett Marsh. They measured the activities of four radium isotopes (Ra-226, Ra-228, Ra-223 and Ra-224) at the marsh in 1999 and 2001. They compared the results, which they obtained with radium activities measured at the same location in 1983 and 1985. They found that the long-lived radium isotopes (Ra-226 and Ra-228) activities were two times higher and 1.5 time higher for the short-lived isotopes (Ra-223 and Ra-224) in 1999 than that during the other three time periods. They estimated the total groundwater discharge to the marsh, which include both freshwater and re-circulated seawater. They compared the results of SGD, which they obtained, with the other results, which obtained from previous studies. Some differences were found between them results and the previous results, which obtained from other researchers who used other different approaches. 
Moore (2003) used radium isotopes (Ra-223, Ra-224 and $\mathrm{Ra}-226, \mathrm{Ra}-228$ ) to determine and estimate sources and fluxes of submarine groundwater discharge (SGD). He collected the radium isotopes samples by using seepage meters, piezometers and surface and deep ocean waters. He found that all samples are unusually enriched in all four radium isotopes (Ra-223, Ra-224, Ra-226, and Ra228). He supposed that this high radium concentration in the Gulf Water came from the groundwater because there is no surface water flow into his study area. He compared the results of radium concentration for the samples, which collected by the different ways. He found that the samples which colleted by seepage meters were about a factor of 2-3 higher in radium activity compared to the overlying waters and the samples which collected by piezometers (1-4 meter below sea-bed) were 1-2 orders of magnitude higher than surface waters.

Charette and Buesseler (2004) investigated the submarine groundwater discharge to evaluate the nutrients and copper to the Elizabeth River estuary. They used an approach based on radium isotopes. They found that radium activities in the groundwater were 10 times more enriched relative to surface waters.

Dulaiova et al. (2004) investigated the groundwater discharge into west Neck Bay in USA by using the chemical tracers.

\subsubsection{Previous Studies on Seepage Meters}

Seepage meters provide point measurements of submarine groundwater discharge (SGD) or, when arrayed in transects offshore, can give an integrated value of SGD per unit length of shoreline (Burnett et al. 2002).

Manual Lee-type seepage meters have been used for many years to measure specific groundwater discharge and then the total discharge (volume per time into a designated area or volume per unit width of shoreline per unit time). It can be calculated by integrating the measured seepage over space and time (Lee, 1977). This method only yields an average discharge rate spanning the small area of measurements (typically area less than 1 square meter). Then many seepage meters are needed to yield discharge estimates representative of a large area (Crusius et al. 2005).

Cable et al. (1997) used the direct seepage measurements in order to focus on groundwater flow through near-shore sediment. They made extensive measurements of flow to document the spatial patterns of groundwater seepage in a small area of the northeastrn Gulf of Mexico. They found that variations in sediment hydraulic conductivity and the presence of impermeable clay layers within a sediment column can cause the channelling of groundwater flow through the aquifers to seepage points in lakes and the coastal ocean. As well they found 
that there is a general decrease in groundwater discharge with increasing distance from shore.

Taniguchi et al. (2002) compiled data from the previous published articles that reported both the measured rate and water depth in order to examine the relationship between direct measurements of submarine groundwater discharge and the water depth. They found that discharge estimates decrease with increasing water depth with about three orders of magnitude.

Taniguchi et al. (2003) measured the submarine groundwater discharge using a different types of automated seepage meters. They measured it also using standard Lee-type manual operated meters. They compared the rate of submarine groundwater discharge obtained from the various automated seepage meters (the continuous heat-type automated seepage meter, the heat pulse-type automated seepage meter and the ultrasonic-type automated seepage meter) with the results obtained from Lee-type manual seepage meters. They found that the groundwater discharge rates measured by the various types of automated seepage meters relatively well with the results measured by Lee-type manual seepage meters.

Schneider et al. (2005) used seepage meters with associated controls in order to quantify rates and directions of groundwater flow along a $120 \mathrm{~m}$ stretch of shoreline of Oneida Lake in New York. They reported that flow changes were highly synchronous among stations but increased in intensity or spikiness both positive and negative, with increasing distance from shoreline, out to a distance of $100 \mathrm{~m}$.

\subsubsection{Previous Studies on Remote Sensing (TIR)}

Rundquist et al. (1985) pioneered the idea of using the thermal infrared remote sensing for quantitative analysis of hydrology of flow-through lakes. They obtained the data from thermal infrared multi spectral (TIMS) airborne scanner in 8.2-12.2 micron range, from NASA National Space Technology Laboratory (NSTL). They selected four lakes in the Sand Hills with greater potential for inference of the zones on intensive groundwater seepage. They detected also the thermal variability and possible groundwater discharge zones to these locations.

Baskin (1990) used the Thermal Infrared Multispectral Scanner (TIMS) for locating the groundwater discharge zones, in the non-mixed motionless environment of the Great Salt Lake. The enhanced Thermal Imaging Multispectral Scanner (TIMS) showed tonal differences associated with variations in surface Temperature. He found that a sharp decrease in digital value as compared to the digital values of surrounding pixels were the initially suspected of being groundwater inflow locations. He mentioned that the size of the thermal anomaly would vary with the volume of water, which is flowing into the lake. This study illustrated the utility of 
the thermal imagery for identifying the density stratification of fresh water over saltwater much like what occurs in coastal systems.

Mckena et al. (2001) mapped the groundwater discharge locations in Rehnoboth River and Indian River bays by using ground aerial thermal infrared and satellite image thermal bands from LANDSAT7 image (60 meter resolutions).

Tcherepanov et al. (2002) evaluated thermal-infrared imaging as a tool for characterizing groundwater - surface water interactions between the lakes and shallow aquifer of the Nebraska Sand Hills. They identify zones of active groundwater-surface water and their orientation with respect to the regional flow by using thermal infrared imaging technique. As well they collect data on the distribution of lake surface temperatures using ground methods (digital thermometer). They compare the results, which they obtained from the surface Temperatures using ground methods with that which they obtained by using satellite (Landsat) image thermal infrared band. They found that the thermal infrared remote sensing has a potential for identification of the groundwater discharge zones in the shallow groundwater.

Ballestero et al. (2004) used field verifications of thermal infrared imagery method and topographic maps to identify the groundwater discharge zones. They mentioned that the field investigations typically involved characterizing the size of the discharge area, confirming an upward groundwater gradient, and quantifying the flow per unit area.

Erica et al. (2005) used high-resolution airborne thermal infrared imagery to locate mine pools and discharges in Kettle Creek watershed-Pennsylvania.

The emitted thermal infrared radiation (TIR) was used to measuring surface water temperatures by Kay et al. (2005). These methods were used to evaluate the accuracy of stream and lake radiant Temperatures derived from airborne (MASTER, 5 to $15 \mathrm{~m}$ ) and satellite (ASTER $90 \mathrm{~m}$, Landsat ETM+ $60 \mathrm{~m}$ resolution) TIR images. They found that agreement between images temperatures and ground Temperatures does not always imply that accurate temperatures have been recovered from TIR images. They concluded that an assessment of thermal stratification should be made in any field area before TIR images are use to measure water temperatures.

Shaban et al. (2005) applied airborne thermal infrared to recognize groundwater discharge along coastal stretch of Lebanon and to compare the results which they got with the results which got by Food and Agriculture Organization (FAO) for the same area and using the same technique. They recognized twenty-seven major SGDs. As well they did a correlation between SGDs and geologic controls on the land after doing interpretation of the satellite images. 


\subsubsection{Previous Studies on Resistivity and Electrical Conductivity}

Salinity anomalies have been used by (Valiela et al. 1990) to identify sub sea freshwater seeps at a variety of scales from regional water budgets to vertical profiles at specific locations.

Manheim et al. (2001) used a streamer resistivity survey 'dipole-dipole' system for defining groundwater discharge into coastal bays of the Delmarva Peninsula. They found that many freshwater anomalies limit to a few hundred meters from the shore at some places and $1 \mathrm{~km}$ or more for some other places.

Crusius et al. (2005) quantified submarine groundwater discharge to the salt pond in USA, using radon and salinity measurements within a channel. They measured the salinity, temperature and depth of the water in the channel every 5 minutes. They measured the radon continuously at the pond. From the temperature and salinity measurements they observed that the channel was well mixed and the changes in channel temperatures were less consistent than changes in salinity and radon values. As well they found that the surface water salinity was demonstrably lower than deep-water salinity during only one profiles due to high tide. After low tide they found that a consistently a minimum in salinity and maximum in radon activity, which suggest inflow of low salinity groundwater. As well they used the salt balance calculations to constraint on the discharge of fresh groundwater to the pond. They assume that fresh groundwater is the only source of fresh water inters the system and they ignore the evaporation.

\subsubsection{Previous Studies on Water Budget and Hydrogeological Model}

A water budget is one of the methods that always done on a regional scale, including when applied to estimate submarine groundwater discharge. Water budget calculates the freshwater inputs and outtakes from the groundwater system.

This method is based on the conceptual model of dynamics of groundwater flow or is based on the examination of sea-side watersheds include the analysis of the geological and hydrogeological conditions in the coastal part of the sea and incorporate hydrodynamic calculations of flow rates (analytically or through simulation), hydrological-hydrogeological method, and the method of normal annual water balance for groundwater recharge zones.

In general saying a water balance (water budget) of a standing body of water is viewed as the equilibrium between water inflow components, outflow components, and the change in the water volume over a particular time interval (Feruson, 1981). Smith and Nield, (2003) and Smith and Zawadzki, (2003) used the water budget and hydrogeological methods for estimating the submarine groundwater discharge in western Australia and in Florida respectively. 
Pluhowski and Kantrowitz (1964) estimated the submarine outflow in Babylon-Islip area, Suffolk County and Long Island, New York. They used both the water balance equation of the groundwater reservoir and Darcy's formula. They calculated the groundwater discharge by using water balance is about $(68,000$ $\mathrm{m}^{3} /$ day), and the quantity is about $\left(72,000 \mathrm{~m}^{3} /\right.$ day) by using Darcy's formula. The difference in both estimates was explained by the inaccuracy of values of permeability and hydraulic gradients, which were used in Darcy's formula computations.

Mower (1968) also estimated the confined groundwater discharged directly into Great Salt Lake by applying Darcy's formula. Burdon and Papakis (1961), investigate the groundwater discharge through inland and coastal springs in Gulf of Corinth, Greece by using water balance.

Borisenko (2001) discussed the structural hydrogeological model based on the assumption of the leading role of faults in groundwater distribution. He found that groundwater drained by a streak-strip faults and discharge into the sea through this fault.

Elhatip (2003) estimated the discharge volume from the submarine springs on the Mediterranean coast of Turkey by using hydrogeological studies. He carried out some field measurements of $\mathrm{Cl}$ contents and electrical conductivity for outlet points and in several sections against depth of seawater. In order to determine the ratio of freshwater per unit volume of saline water discharge from the submarine springs. As well he used the water budget for a period of 10 years to calculate the recharge and the discharge of that submarine springs.

Vsevolozhskii and Kochetkova (2003) mentioned that the combination of the climate, relief, landscape and geomorphological conditions, geological structure, and hydrogeological conditions are controlling the values of specific characteristics of groundwater runoff, as well as their distribution and the contribution to the formation of water budget

Destouni and Prieto (2003) simulated large-scale dynamics and resulting of submarine groundwater discharge SGD in three different coastal aquifers on the Mediterranean Sea. They used the water budget techniques for their study.

\subsection{Specific Previous Studies on the Dead Sea}

Neev and Emery (1967) studied the layering of the Dead Sea water. They mentioned that the shallow water layer of the Dead Sea the upper 40 meters undergo seasonal variations in both density and salinity. They found that a sharp increase of both density and salinity occurs at $40 \mathrm{~m}$. The deeper layer, which is below 100 m depth the density, and salinity remain nearly uniform as a function of depth. They found also that the temperature, density, and salinity of the water, indicate that there are two main layers of water are present in the North Basin. 
These two layers (the upper water mass and the lower water mass) are divided by a clear and sharp boundary at about $40 \mathrm{~m}$ depth. They divided the upper water mass into two members, which are surface member, and beneath surface member. The first member is varying seasonally in thickness and properties. It affected by runoff, evaporating, solar heating and currents. These properties of this member are uniform from top to the bottom of the member. The depth of this member is about $15 \mathrm{~m}$ in spring and about $40 \mathrm{~m}$ in early winter.

Stiller and Chung (1984) measured the radium-226 in the meromictic Dead Sea during 1963-1978 for three profiles along the western shoreline of the Dead Sea for a depth of about $300 \mathrm{~m}$. They found that the radium activities in the upper water mass for the depth between 0 and $160 \mathrm{~m}$ were higher than that in the lower water mass. On the other hand they mentioned that the radium inventory for the three profiles were similar. They tried also to find the geological origin of radium in the Dead Sea. They mentioned that the origin of radium at the Dead Sea is not from neither the salt domes nor from igneous and sedimentary source beneath the deep part of the Dead Sea, because the radium concentrations in the upper water layer was much higher than that at the lower one. They suggested that the Dead Sea pore water, which migrates landwards, then flushed back by meteoric waters, could be a source of radium for some of its shoreline springs. They mentioned also that the lower water mass was a layer of fossil water that had been isolated at least for several centuries.

Steinhorn (1985) described the overturn process on a seasonal scale, and the reason for the destruction of the long-term stratification of the Dead Sea. He mentioned that the surface layers were cool in autumn and depth of mixed layer increases. As well the lake was cooled in winter and warmed up in spring, the salinity of its surface layers decreases due to the higher inflow rate from October to May. The surface layers $(0-5 \mathrm{~m}$ or $10 \mathrm{~m})$ are usually colder in winter and warmer in spring than the layers underneath. He found that the temperatures in October 1975 was sharp thermocline at about 25-m depth and the salinities at region from 65 to $75 \mathrm{~m}$ consisted of water layers with alternating low and high temperatures and also salinity. He found also that the surface Temperatures in July 1977 were high, $32^{\circ}-37^{\circ} \mathrm{C}$, with temperature gradient, accompanied by a reversed salinity gradient, in the upper 20-30 m. In February 1979 the water column of the Dead Sea was homogeneous in physical properties; except for relatively small diurnal variations in the upper $10 \mathrm{~m}$. in august 1978 he found that the surface layers had higher salinity values than did the bottom layers. The mixolimnion 'the middle circulating layer' of the lake became deeper from about $80 \mathrm{~m}$ in 1975 to $110 \mathrm{~m}$ in 1976, $150 \mathrm{~m}$ in 1977, and $180 \mathrm{~m}$ in 1978. As well he evaluates the density, salinity and temperature of the Dead Sea water column.

Salameh and Rimawi (1988) studied the hydrochemical and the groundwater system of Zara-Zarqa Ma'in thermal field. They found that the salinity of the thermal springs in the region is high. They connected this high salinity of Zarqa 
Ma'in thermal water to a possible mixing with the Dead Sea saline water. This is might be due to the Dead Sea water connected with the submarine aquifers and circulation of the Dead Sea water.

Gavrieli et al. (1989) found that the Dead Sea is presently saturated to oversaturate with respect to aragonite $\left(\mathrm{CaCo}_{3}\right)$, anhydrite $\left(\mathrm{CaSO}_{4}\right)$, and halite $(\mathrm{NaCl})$.

Beyth et al. (1993) computed the quasi-salinity the Dead Sea water. They found that the quasi salinity of the surface layer of the Dead Sea saline water reached a maximum of $236 \mathrm{~kg} \cdot \mathrm{m}^{-3}$ during the summer of 1991 . But it dropped to $164 \mathrm{~kg} \cdot \mathrm{m}^{-3}$ during the following winter due to heavily rainy season and rain flooded to the Dead Sea surface layer.

Abu-Jaber and Wafa (1996) investigate the hydrochemistry of the groundwater in the alluvial and deep sandstone aquifer in Safi and Haditha fields. They found that there is no obvious long-term degradation in the water quality can be identified. On the other hand there is degradation in the water quality with time within the distal portions of the alluvial fan due to the dissolution of the Lisan Marl.

Jiries and El-Alali (1996) studied the mechanism of salt Reef growth in the southern basin of the Dead Sea. They found that Reef growth at this area is due to common ion effect of chloride ions, from mixing of two different type of water, namely the artisan water issuing from groundwater flow, and the saltpan brine Dead Sea water.

Yiechieli et al. (1996) studied the source and age of the groundwater brines in the Dead Sea area using $\mathrm{Cl}^{36}$ and $\mathrm{Cl}^{14}$. They found that the groundwater brines in the Dead Sea area are the results of direct infiltration of brines from precursor Dead Sea Lake.

Gavrieli (1997) modeled the effect of evaporation and the consequent concentration increases on the saturation index of the Dead Sea surface brine. He found that a $1 \%$ increase in concentration equivalent to about $1 \%$ volume evaporation, increase the saturation index of the 1959-1960 lower water mass from 1.01 at $25^{\circ} \mathrm{C}$ to 1.06 , even though a $2 \%$ volume evaporation increase the index to 1.11. As well a $1 \%$ evaporation of the 1979 surface brine increases its saturation index from 1.11 to 1.16 and $2 \%$ evaporation increasing the index from 1.11 to 1.22 . He mentioned also that for $35^{\circ} \mathrm{C}$ undersaturated $1990\left(\Omega_{\text {halite }}=0.94\right)$ surface brine, evaporation of $3.3 \%$ was required to reach a saturation index of 1.11 . He defined the halite saturation index as:

$\Omega_{\text {halite }}=a_{\mathrm{Na}}{ }^{*} a_{\mathrm{Cl}} / \mathrm{K}_{\mathrm{h}}$. where $\mathrm{a}_{\mathrm{Na}}$ is the activity of $\mathrm{Na}, \mathrm{a}_{\mathrm{Cl}}$ is the activity of $\mathrm{Cl}$ and $\mathrm{K}_{\mathrm{h}}$ is the thermodynamic solubility constant of halite. 
Krumgalz (1997) applied the Pitzer system of equations to Dead Sea water as natural hyper-saline brines. He found that the degree of gypsum over-saturation in the Dead Sea water is less than 1.7, then he expected that the mixing of the Dead Sea water with rainwater and water coming from the springs surrounding the Dead Sea might be changed the gypsum precipitation-dissolution equilibrium. As well he mentioned that mixtures of the Dead Sea water with more than $10 \%$ wt. of freshwater became under-saturated with respect to gypsum. He determined also the degree of saturation of the different minerals in the Dead Sea water as the Degree of saturation of aragonite; calcite, dolomite, anhydrite, sulfite, maginesite and halite were $3.2,4.92,421,2.23,0.16,12.3$ and 0.94 respectively, but they did not mention are the saturation of these mineral at the Dead Sea surface water or at the deeper water layers.

Niemi and Ben-Avrahm (1997) analyzed the $3.5 \mathrm{kHz}$ seismic reflection along the east to west trending of En Gadi fault which mapped by Neev and Hall (1976, 1979). They characterized a complex region of faults, channels and escarpments of uncertain origin. The date indicates a crosscutting relationship between the fault systems, with the northeast-trending faults. From the interpretation of these trends an interesting feature was observed at the fault intersection of the Ein Gedi fault and the northeast-trending intrabasinal fault is an expected a site of hydrothermal activity, which possibly is a hot springs on the floor of the Dead Sea.

Anati (1998) divided the Dead Sea water column into two water bodies; the deep water layer extending to $326 \mathrm{~m}$ below sea surface constituting most of the sea volume, and a shallow upper layer a few meters thick (between 5 and $20 \mathrm{~m}$ ). The lower layer effected with a little vertical variation, while the upper layer is depending on the season and the regime. The salinity of the seawater increases continuously out of the rainy season (December to March), and decreases by the same amount in a balance year during the short rainy season (December to March). Anati found that the salinity of the upper layer water type in spring of 1980 increased by 5 times faster than in the spring of 1985. In spite of a similar evaporation rate and similar surface salinity in the two stages, and occurred during a season with no inflowing fresh water. According to Anati (1998) the deep water layer of the Dead Sea is isolated from the outside influenced during a complete seasonal cycle and consequently remain constant in all their properties during the 1979-1982 meromictic regime. She mentioned that the deep water attains its highest temperature in December and its lowest salinity in June, July or August.

Salameh and El-Naser (1999) estimated the water discharge to the Dead Sea by using water balance calculations. They compared the water balance before (predevelopment) and after water resources development. They found that the amount of water that used to flow into the Dead Sea before development was 1980 $\mathrm{MM}^{3} / \mathrm{y}$ and after development (present day) is about $617 \mathrm{MM}^{3} / \mathrm{y}$ for the total catchments area of the Dead Sea. 
Asmar and Ergenzinger (1999) estimated the evaporation from the Dead Sea over a range of salinity between 0 and $500 \mathrm{~g} / \mathrm{l}$. They used two methods approach for that. One is the modified penman method and the other is the modified Dalton-type formula. They found that the evaporation from the Dead Sea will drop to Zero at the salinity of $486.2 \mathrm{~g} / \mathrm{l}$ by using Penman method and it will drop to zero at salinity of $483.55 \mathrm{~g} / \mathrm{l}$ by using Delton method.

Krumgalz et al. (2000) issued a model for predicting the evaporation from the Dead Sea related to the Dead Sea level. They found that the evaporation from the Dead Sea would reach a balance, which will protect the further reduction of its level. This is expected to occur when the Dead Sea level drop to about $-550 \mathrm{~m}$ below mean sea level.

Salameh and El-Naser (2000a), studied the saltwater - freshwater interface and transition zone in the groundwater flow system of Dead Sea in Zarka Ma'in area in detailed. They mentioned that the saltwater-freshwater interface starts at the shores of the Dead Sea with very steep gradient of inclination and gradually events out landward where it tends to become horizontal at an aquiclude. By using Ghyben - Herzberg formulas, which consider the density of the Dead Sea water

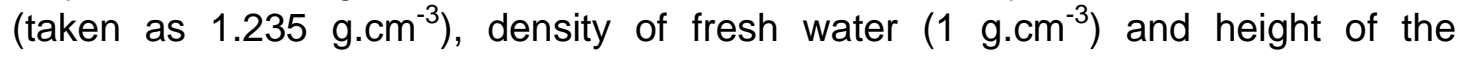
groundwater level for a known point relative to the Dead Sea. They found that the depth of the interface between the fresh water and Dead Sea water is $4.255 \mathrm{~m}$ deeper for one meter increasing in groundwater level. Figure (2-1) shows the relationship between the groundwater level and the interface between the fresh water and seawater. Z1 is the depth of interface at groundwater level h1 and $\mathrm{z} 2$ is the interface depth at $\mathrm{h} 2$ groundwater level.

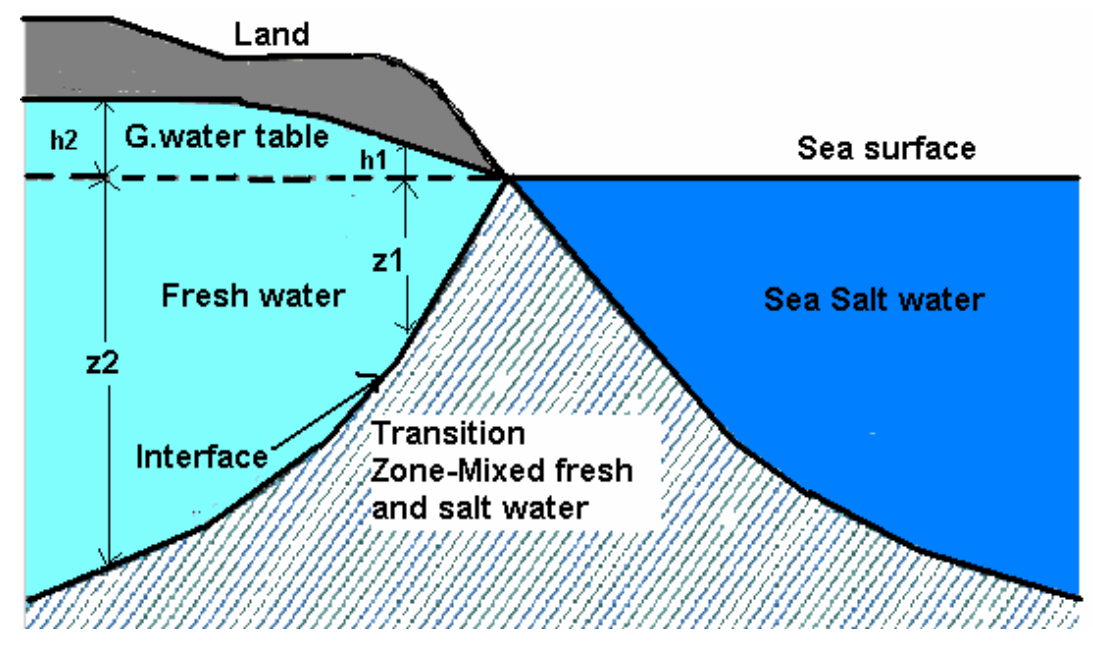

Figure (2-1): Schematic diagram showing the relationship between groundwater level and depth of the interface.

Salameh and El-Naser (2000b) reported that the interface seaward migration resulted in a groundwater discharge estimated at approximately $400 \mathrm{MM}^{3}$ per 
meter drop in the level of the Dead Sea during the period between 1994 and 1998. They also mentioned that at the present day the loss of fresh water to the Dead Sea through the interface readjustment mechanism is calculated $370 \mathrm{MM}^{3} / y e a r$ as a result of over exploitation of waters that formerly fed the Dead Sea.

Getman and Hecht (2002) studied the hydrograph of the Dead Sea at the period from 1992 to 2000. The study area, which they considered, was at middle off the Dead Sea with about $12 \mathrm{Km}$ and $5 \mathrm{Km}$ from the west shoreline of the Dead Sea. They mentioned that the surface level of the Dead Sea has been lowered by an average rate of about $0.60 \mathrm{~m} /$ year since 1977 and for the period from 1998 to 2000 , the lowering rate has reached about $1 \mathrm{~m} /$ year. They reported that the upper layer salinity of the Dead Sea has been increased and the gravitational stability of the water body diminished due to the runoff reduction. They did some evaluation of water temperature and quasi salinity at 1 and $30 \mathrm{~m}$ depth. They found that during summer, the seasonal thermocline is constantly above the $30 \mathrm{~m}$ level, while during the autumn; the thermocline deepens below $30 \mathrm{~m}$. As a result the intensification of thermal fluctuation during this period shows the intermittent character of the mixing processes. After end of March, evaporation induces a salt concentration increase in the layer above the thermocline. They mentioned that the thickness of the upper layer during July and August is about $25-28 \mathrm{~m}$. They considered two cooling process phases in the holomictic period. The upper layer of the Dead Sea water that is above the seasonal thermocline was affected by the first phase with cooling rate of about $0.1^{\circ} \mathrm{C}$.day ${ }^{-1}$. When the thermocline got beneath the $30 \mathrm{~m}$ depth, then about 30 days is necessary to entirely mix the Dead Sea volume. They donated that the salinity of the meromictic upper layer increased dramatically and in the summer of 1995, it overshot the salinity of the deep water.

Gavrieli and Oren (2004) studied the stratification of the Dead Sea. They observed that the stratification is maintained by a stabilizing thermocline (between $25 \mathrm{~m}$ and $30 \mathrm{~m}$ ) during the summer months. They found that the surface water temperatures might reach $35-36^{\circ} \mathrm{C}$, while the temperature of the water mass below the thermocline remains stable between $22-23^{\circ} \mathrm{C}$. They mentioned that this stabilizing thermocline is sufficient to balance the destabilizing halocline that is formed during the summer months as a result of increased evaporation. As well they found that the over turn occurs following the autumn cooling of the upper water column and the increase in its density. They found also that the Kinetic factors which dominant over thermodynamic considerations indicate that gypsum $\left(\mathrm{CaSO}_{4} \cdot 2 \mathrm{H}_{2} \mathrm{O}\right)$, rather than anhydrite is the actual Ca-sulphate mineral that precipitate from the Dead Sea brine. The $\mathrm{Na} / \mathrm{Cl}$ ratio has slightly decreased over the years due to precipitation of halite from the Dead Sea brine.

\subsection{Background Information}




\subsubsection{Geology of the Dead Sea Area}

The Dead Sea area lies at the north margin of the Arabian Shield. From the plate tectonic point of view it is located at the western margin of the Arabian plate, which is separated from the Palestine Sinai plate by the Dead Sea Rift with horizontall displacement to the north relative to the Palestine Plate (Freund et al. 1970).

According to Bender (1968) the Dead Sea area has been controlled through the geological history by two factors, namely:

- The Tithys Ocean, which invaded the region several times, depositing the marine successions.

- The presence of the neighbouring Arabian Shield in the south, which displayed an important source for sediments.

\subsubsection{Stratigraphy of the Study Area}

Cretaceous rocks cover the eastern part of the investigated area, while westwards; the oldest formations are of middle Cambrian age. Close to the eastern shoreline of the Dead Sea, Triassic and Lower Cretaceous rock crop out. Volcanic eruptions occur in many places of the area but mostly in the western part along the Dead Sea coast. The stratigraphical lowest outcropping member is the Cambrian; Umm Ishrin formation, which consists of sandstone followed up by Triassic Zarka Ma'in group consisting of sandstones, limestone and shale, followed up by the Lower Cretaceous Kurnub sandstone and the Upper Cretaceous Ajlun group being mainly a carbonate-dominated sequence. Belqa group Upper Cretaceous - Tertiary follows it. This group is missing in the end northern part of the study area. The youngest geological units are the Quaternary Lisan marl of Pleistocene age (Bender, 1974) and the basalt flows dated 0.6 Ma BP (Duffield et al. 1987). Figure (2-2) shows the geological and structural map of the area surrounding the Dead Sea.

The sequence of the lithological units of the Dead Sea area is shown in table (2-1). The detailed of these units are described in the geological maps Ma'in, Ar-Raba and the southern part of Al-Karameh sheet in scale 1:50,000, which were produced by the Geological Mapping Division in NRA. The details are described as the following: 


\subsubsection{Ram Sandstone Group}

This group has named by Quennell (1951) and Burdon (1959). It is concedered one of the lower aquifer in the area. This group divided into two formations in the study area as following:

- Burj Dolomite-shale Formation (BDS)

Only the uppermost part of the carbonate sequence of this formation is exposed in Wadi Zarka Ma'in area. The outcrop extends about $1 \mathrm{~km}$ to the north along the eastern shoreline of the Dead Sea. This formation had defined by Quennel (1951). It consists of dolomitic limestone, dolomite and sandy dolomite. The age of this formation is Lower to Middle Camprian.

- Um Ishrin Sandstone Formation (IN)

This formation has named by Lloyd (1969). It is equivalent to Quwiera sandstone as Quennel (1951) and Burdon (1959). It crops out at the in the west along the Dead Sea escarpment north of Wadi Al Hasa and at the eastern part of the Dead Sea at Wadi Al-Hidan. It is steeping rugged cliffs and deep Wadies to the south. It consists of brown, red-brown, yellowish, and red-violet colored, medium to coarse grained, massive weathered sandstone. The thickness of Umm-Ishrin formation is about $300-350 \mathrm{~m}$. The age of this formation is Lower to Middle Cambrian (Freund et al., 1975).

\subsubsection{Zarka Ma'in Group (MK-MN)}

Blake (1936) described the Triassic Rocks near the mouth of Wadi Huni and Wadi Zarka Ma'in $25 \mathrm{~km}$ of south Wadi Hisban. It was divided into six Formations as following:

- Umm Irna Sandstone Formation

The outcrop of this formation is restricted to cliffs adjacent to the Dead Sea shorelines. It consists of lower thin-bedded clastics unit and upper thick bedded clastic unit. It consists of sandstone upward fining sequences. It is from PermoTriassic age (Bandel and Khouri 1981).

\section{- Ma'in Sandstone Formation}

It consists of fine to coarse-grained sandstone, siltstone, and clay intercalated with carbonate rocks. It crops out along the Dead Sea shorelines and in deep Wadis between Wadi Mukheiris to the north and Al Mamaleh to the south. It is from a Scythian age. 
- Dardour Formation

This formation is from an Anisian-Carnian age. It consists of cream, yellowish, black and dark green marl, shale, dolomitic limestone with cross-bedded sandstone and dolomitic sandstone. It crops out along the Dead Sea shorelines between Wadi Abu Khusheiba to the south and Wadi Mukheiris to the north.

- Ain Musa Formation

It consists of massive glauconitic sandstone intercalated with siltstone, clay beds, marl and fossiliferous limestone. It crops out between Wadi Manshala to the south and Wadi Mukheiris to the north along the eastern shoreline of Dead Sea. It is age from Anisian (Bandel and Khoury, 1981).

- Hisban Limestone Formation

It consists of massive dolomitized limestone. Its age is early Anisian (Parnes, 1975).

- Mukheiris formation

It crops out in Wadi Mukheiris directly at the shore of the Dead Sea in Wadi Mukheiris and Wadi Dardur. It consists of calcareous sandstone intercalated with sand and clay (Bandel and Khoury 1981). Its age is from early Ladinian.

\subsubsection{Kurnub Sandstone Group (KS)}

Kurnub sandstone is locally cropping out along the eastern heights of Jordan Valley along the rift margins along the eastern shoreline of the Dead Sea. It forms accessible cliffs above the steep escarpment of the harder Umm Ishrin Sandstone. Kurnub sandstone is composed mainly of red, violet, purple, and brown sandstone with varying proportion of clay and siltstone beds. The upper part of this unit is characterized by the increase in the presence silty shale and marl and characterized by cross bedding. Its thickness in Zarka-Ma'in is around $330 \mathrm{~m}$ (Bender 1974). The age of this group is Neocommian to Cenomanian from Mesozoic Era. It is one of the deep aquifers in the area.

\subsubsection{Ajlun Group}

Ajlun group discomformably overlays the Kurnub sandstone group. It has been subdivided into five formations as follows: 
- Na'ur Limestone Formation $\left(A_{1}-A_{2}\right)$

It consists of succession of limestone, dolomite and marl (Powell, 1989). Its age is from Lower Cenomanian. It crops out in the deep Wadies in the central parts of the Ma'in sheet east of the Dead Sea. It is one of the minor aquifers in Jordan.

- Fuhays Formation $\left(A_{3}\right)$

It is equivalent to $A_{3}$ and the middle part of the Nodular limestone of Bender (1974). It is consisted of yellow grey calcareous siltstone, marl and marly limestone, nodular limestone and fossiliferous limestone. It exposes along the deep Wadies north of Wadi Abu khusheiba and road cuts between Ma'in village and Ma'in hot springs. The age of this formation is Cenomanian.

- Hummer Formation $\left(\mathrm{A}_{4}\right)$

It is equivalent to $A_{4}$ and to the echinoidal limestone of Bender (1974). It consists mainly of grey limestone, dolomitic limestone and dolomite. The age of this formation is Cenomanian. It is crops out north of Wadi Abu Khusheiba along the Dead Sea shoreline. It is a minor aquifer in the area.

- Shuayb Formation $\left(A_{5}-A_{6}\right)$

It is equivalent to $A_{5}$ and $A_{6}$. It consists of red green buff calcareous siltstone with gypsum viens and thin limestone beds with orange algallaminated dolomite and mudstone. It crops out in north of Wadi Abu Khusheiba along the Dead Sea shoreline. Its age is Early Turonian.

- Wadi Es-Sir Limestone Formation $\left(A_{7}\right)$

It comprises the upper most part of Ajlun group $\left(A_{7}\right)$ (Mackdonaled et al. 1965). It consists of limestones, dolomitic limestones, marly sandstone, chert. The upper part consists of thick-bedded fossiliferous limestone alternating of thin chert bands. Its thickness is about $100 \mathrm{~m}$ in Wadi Abu Khusheiba and $85 \mathrm{~m}$ north of Wadi Zarqa Ma'in. It crops out at the middle part of the Dead Sea along the shoreline.

\subsubsection{Belqa Group}

The age of this group ranges from Coniacian to Eocene. It had divided lithologically by Paker (1970) into four formations as the follows:

- Wadi Umm Ghudran Formation $\left(\mathrm{B}_{1}\right)$ 
It is equivalent to $B_{1}$ (Mackdonald et al. 1965), and equivalent to upper part of massive limestone (Bender, 1974). This formation is well exposed above the prominent cliff, which is formed Wadi Es-Sir (A7) formation at the north and south of Zarka Ma'in fault. It consists of white or buff chalk with bed of grey chert, phosphatic sandstone and phosphatic siltstone (Bender, 1974 and Powell, 1988). The age of this formation is Coniancian-Campanian (Powell, 1988).

- Amman Silicified Limestone Formation $\left(B_{2}\right)$

This formation consists of limestone, dolomite intercalation with chert and lamians of chalk.

It crops out in the deeply incised Wadi Al-Hidan and south of Wadi Mujeb. The age of this formation is Campanian. This formation compined with $B_{2}$ formation is considering a main upper aquifer $\left(B_{2} / A_{7}\right)$ in the area.

- Al Hisa Phosphorite Formation $\left(\mathrm{B}_{3}\right)$

It consists of calcareous, silicified, argiallaceous phosphorites beds, limestone, chert, marl, and oyster lumlachella (coquina) beds. It crops out at the east of the southern part of the Dead Sea between Wadi Mujeb and Wadi Al Hidan and south of Wadi Mujeb (Wadi Al Hasa). The age of this formation is Campanian to Maastrichtian-Danian (Powell, 1988).

- Muwaqar Formation $\left(\mathrm{B}_{4}\right)$

It poorly crops out at the southern part of the Dead Sea at south and north of Siwaqa fault. It is covering with soil in the south and north of Wadi Mujeb. It consists of soft marl and white yellowish chalk. The age of this formation is Upper Maastrichtian.

- Um Rijam Formation $\left(B_{5}\right)$

The outcrops of this formation are restricted to the Adh Dhira Monocline south of Wadi Al Karak. It consists of chalk, chalky limestone, and phosphatic limestone with laminas of chert. Its age is Early Palaeocene to Eocene.

\subsubsection{Dana Conglomerate (DC)}

It crops out at the end southern part of the Dead Sea at the Adh Dhira area at Wadi Al Karak. It consists of marl, and sandy marl, layers and nodules of conglomerate. Its age is Oligocene. 


\subsubsection{Lisan Marl Formation (LMg)}

It presents adjacent to the Dead Sea unconformable on strata. It is ranging in age from Cambrian to Neogene (Bender, 1974).

\subsubsection{Superficial Deposits}

- Fluviatile and Lacustrine Gravel (PL)

It consists of coarse-grained sand and gravels. The latter composed of sub-angular pebbles and cobbles. Clasts are chert, limestone, dolomitic limestone, sandstone and basalt.

- Alluvial Fans

It consists of sand and gravel with soil covered developed in Holocene to present.

- Travertine

It is a carbonate rock resulting from the precipitation of limestone from hot waters and its age is Pleistocene (Bender, 1974).

\subsubsection{Volcanic Rocks}

Basalts crops out between Siwaqa fault and Wadi Ash Shaqiq. It is recorded of 10 $\mathrm{m}$ basalt on the flanks of Wadi Mujeb (Barberi, et al. 1980). It crops out along Zarka Ma'in fault and at some locations to the east of the Dead Sea. 
Table (2-1): Chronological sequence of the lithological units area (Internal reports, NRA)

\begin{tabular}{|c|c|c|c|c|}
\hline Period & Age & Group & Unit & Lithology \\
\hline \multirow{2}{*}{ Quaternary } & Recent & & River,Terrace & Gravel, Clay, Sand \\
\hline & Pleistocene & \multirow{4}{*}{ 壭 } & Lisan & $\begin{array}{l}\text { Marl, Gravel, Clay, } \\
\text { Gypsum, Sand }\end{array}$ \\
\hline \multirow{5}{*}{ Tertiary } & Pliocene & & & \\
\hline & Miocene & & Undifferentiated & Conglomerate, Marl \\
\hline & Oligocene & & & \\
\hline & Eocene & \multirow{5}{*}{$\frac{\sigma}{0}$} & Wadi Shallala(B5) & No data at Dead Sea area \\
\hline & Paleocene & & Umm Rijam(B4) & Limestone,Chert \\
\hline \multirow{8}{*}{$\begin{array}{l}\text { Upper } \\
\text { Cretaceous }\end{array}$} & Maestrichtian & & \begin{tabular}{|l} 
Muwaqqar(B3) \\
\end{tabular} & Chalky Marl \\
\hline & Companian & & $\begin{array}{l}\text { Al Hasa(B2a) } \\
\text { Amman(B2b) }\end{array}$ & $\begin{array}{l}\text { Phosphate } \\
\text { Silic. Limestone }\end{array}$ \\
\hline & Santonian & & W. Ghudran(B1) & Chalky Marl, Chalk \\
\hline & Turonian & \multirow{5}{*}{$\stackrel{\Xi}{\Xi}$} & Wadi Es Sir(A7) & Limestone \\
\hline & & & Shueib(A5-6) & Marly Limestone \\
\hline & & & Hummar(A4) & Dolomatic Limestone \\
\hline & & & Fuheis(A3) & Marl \\
\hline & & & Na'ur(A1-2) & Marly Limestone \\
\hline \multirow{3}{*}{$\begin{array}{l}\text { Lower } \\
\text { Cretaceous }\end{array}$} & Albian & \multirow{3}{*}{ 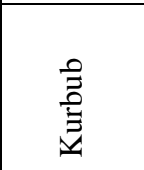 } & \multirow[t]{3}{*}{ Kurnub Sandstone } & White Sand Stone \\
\hline & Aptian & & & Varicolored Sandstone \\
\hline & Neocomian & & & Lst.,Shale, marl, dolomite. \\
\hline \multirow[t]{3}{*}{ Permo Triassic } & & \multirow{3}{*}{ 莺 } & Dardur & Sandstone, Marl, Shale \\
\hline & & & Ma'in & Sandstone, Siltstone,Clay \\
\hline & & & Umm Irna & Sandstone, Siltst., Shale \\
\hline \begin{tabular}{|l|} 
Silurian \\
\end{tabular} & No Strata & Present i & n The Dead & Sea Area \\
\hline \multirow{4}{*}{ Ordovician } & \multirow[t]{4}{*}{ No Strata } & Present in & The Dead & Sea Area. \\
\hline & & & & \\
\hline & & \multirow{5}{*}{$\underset{\Xi}{\approx}$} & Umm Sahm & No strata at the Dead Sea \\
\hline & & & Disi & No Strata at the Dead Sea \\
\hline \multirow{3}{*}{ Camprian } & & & Umm Ishrin & Sandstone, Siltstone \\
\hline & & & Burj & Dolomite,Shale,Sandst. \\
\hline & & & Salib & Sandstone, Siltstone \\
\hline Pre-Camprian & & ஸั & Not presented & In the Dead Sea Area \\
\hline
\end{tabular}




\subsubsection{Structural Settings in the Dead Sea Area}

Most of the structural features in the study area are parts of and influenced by the prominent outstanding structural feature affecting the whole are along Jordan Graben.

The Dead Sea Transform in Jordan is composed of three morphotectonic segments; Wadi Araba at the south, Dead Sea at the middle and Jordan Valley at the north. Together they form morphological depression that extends from the Gulf of Aqaba to Lake Tiberias about $360 \mathrm{~km}$ long (Bender, 1974). It is a part of the east African-South Turkey rift system that has a total length of $6000 \mathrm{~km}$ (Bender, 1974). The Wadi Araba segment trends $15^{\circ}$ east of $\mathrm{N}$ with length about $200 \mathrm{~km}$ while the Dead Sea -Jordan Valley Rift segments trends with $5^{\circ} \mathrm{NE}$ with about $160 \mathrm{~km}$ length (Burdon, 1959, Bender, 1974).

In addition to the Dead Sea transform fault system, which is the major active strike - slip fault system, there are many other structural features in the area between the northern end of the Dead Sea and the northern part of Wadi Araba. These are:

- Zarka Ma'in Fault

This fault commences at the Dead Sea and continues eastwards. The downthrown of this fault is about $250 \mathrm{~m}$ near the Dead Sea. The downthrown decreases eastwards and turns over in a flexture. On the southern part of this fault basaltic eruption occurred at the downthrown block, while hot springs issue on the northern block from Lower Cretaceous Kurnub Sandstone (Wiesemann, 1969). It trends EW.

\section{- Wadi Atun Fault}

This fault trends E-W. It extends from the Dead Sea shore to Wadi Wala. It is subparallel to Zarka Ma'in Fault. It divides Zara area into north and south Zara.

- El-Maslubia Fault

It starts at Wadi Kashem Jiwan basalt (in the northwest) and extends for about 5 $\mathrm{km}$ eastwards (north of Ma'in village). It trends $\mathrm{E}-\mathrm{W}$.

- Humrat Ma'in Fault

It is parallel to the Dead Sea coast in the southern part between Wadi Zarqa Ma'in and Wadi Manshala. It appears $2 \mathrm{~km}$ east of the Dead Sea coast at its southern part and $4 \mathrm{~km}$ distance from the Dead Sea at its northern end (Atalla 1981). It trends NE-SW and the downthrown is the NW block. 
- Zara Fault

It trends $\mathrm{N}-\mathrm{S}$. It commences north of Wadi Mujeb and runs along the eastern escarpment of the Dead Sea. The hot springs in Zara area are related to this fault (Wiesemann, 1969).

- Wadi er Rashsha Fault

This fault extends from upper Wadi Zerka Ma'in to about $1 \mathrm{~km}$ south of Ma'in village. It is trending NE-SW and the downthrown is towards the SE.

- The Karak Al-Fiha Fault zone

It rends NW-SE and extendsabout $300 \mathrm{~km}$.

- The Siwaqa Structure

It is a normal fault, which strikes between NNE and ENE. It has a northern downthrown, while the eastern main fault has a southern downthrown. The faults trend NE-SW, while it trends NW-SE in the northern part of the area (Atalla 1981).

- Amman-Halabat Structure- NE-SW trending

- Wadi Zarka Ma'in Syncline

It passes gradually through a graben and pluges westwards. Its axis is almost along the Wadi and parallel to the Zarka Ma'in fault. Both the graben and the syncline are asymmetric.

- Wadi Um Ghureiba Anticline

It is exposed east of the Dead Sea at Um Ghureiba north of Wadi Mujeb with a NE axial strike. The extension of this anticline is about $8 \mathrm{~km}$.

- Quallat Et Taweiyil Anticline

It extends for about $3 \mathrm{~km}$ in a NNE-SSW direction along the road to Zarka Ma'in hot springs.

- Hammrat Ma'in Anticline

It is an asymmetrical anticline NNE trending. It starts near Wadi Durdur and extends to about $3 \mathrm{~km}$ to the SSW.

- The Haditha Syncline: it trends NNE-SSW and plunges NNE 
- According to Bender (1968), there are many flexures east of the Dead Sea dipping to the west as (Karak flexure, Wadi Mujeb and Wadi Hisban).

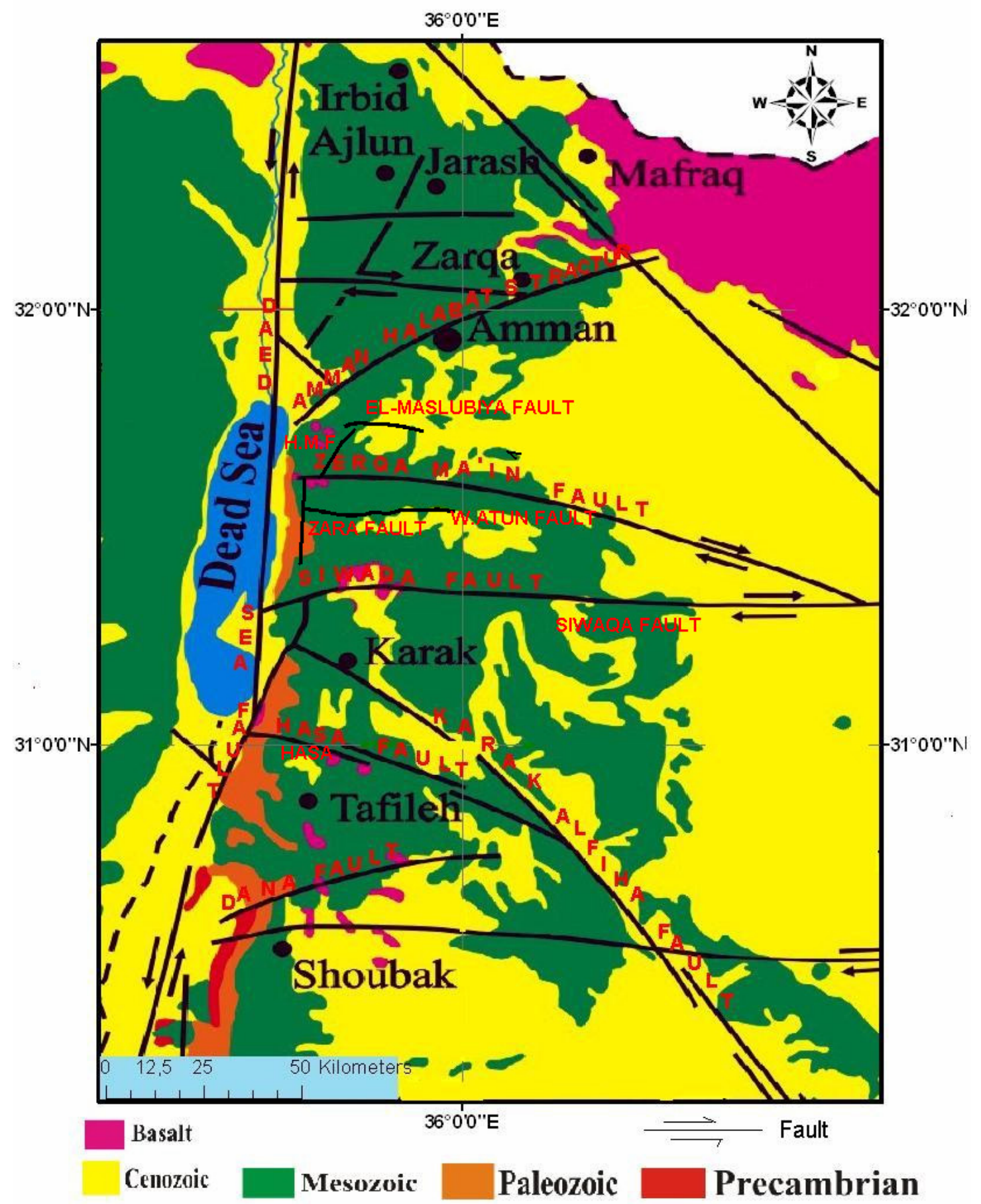

Figure (2-2): Simplified geologic and structural map of the area surrounding the Dead Sea 


\subsubsection{Water Balance}

A water budget is generally carried on a regional scale, including when applied to estimating submarine groundwater discharge. It calculates the freshwater inputs and outtakes from the groundwater system for a long-term average annual submarine discharge (Loaiciga and Zektser, 2003). This kind of approach deals with the water inputs to the groundwater system and assumes that what goes into a coastal aquifer must discharge into the coast.

Because the Dead Sea is an enclosed system and has no underneath water outflow the only losses from the Dead Sea system are only due to evaporation from its surface (Salameh and El-Nasser, 1999). Groundwaters feeding the Dead Sea evaporate when emerging as seepages to the groundsurface and by extraction by the Potash Companies on the both sides of the Dead Sea to produce different kind of salts. Then by accounting for these amounts the hydrological budget can be estimated using the following equation:

$\Delta V=P_{t}+S+G_{n}-E-K$

Where $\Delta \mathrm{V}$ is the change in the Dead Sea volume, $\mathrm{P}_{\mathrm{t}}$ is precipitation over the Dead Sea itself $\left(\mathrm{m}^{3} / \mathrm{y}\right), G_{n}$ is net groundwater flow (inflow-outflow) $\left(\mathrm{m}^{3} / \mathrm{y}\right)$, $S$ is the surface water flow into the Dead Sea $\left(\mathrm{m}^{3} / \mathrm{y}\right)$, $E$ is evaporation $\left(\mathrm{m}^{3} / \mathrm{y}\right)$, and $\mathrm{K}$ is the amount extracted by Potash Company $\left(\mathrm{m}^{3} / \mathrm{y}\right)$. Each parameter was calculated and substituted into the equation. The balance was calculated as an average for a long time period.

An important part of the water balance is the estimation of the surface area and volume of the Dead Sea, since the size of the Dead Sea changes dramatically with time. The surface area and the volume were taken as given in (Salameh and ElNasser, 1999). This water budget was calculated for a long period of time from 1950s until the year 1994/1995 when the Dead Sea level was -410 m below mean sea level.

\subsubsection{Surface Water Flows into the Dead Sea}

The surface water discharges into the Dead Sea come from Jordan River and other Wadies surrounding the Dead Sea from the eastern $\left(S_{e}\right)$ and western sides $\left(S_{w}\right)$ and from Wadi araba $\left(S_{a}\right)$, then the total amount of surface water discharging into the Dead Sea equal the sum of these amounts:

$\mathrm{S}=\mathrm{S}_{\mathrm{r}}+\mathrm{S}_{\mathrm{e}}+\mathrm{S}_{\mathrm{w}}+\mathrm{S}_{\mathrm{a}}$

The total surface water inflow from the Jordan River and its surrounding Wadies is equal to about $142 \mathrm{MCM} / \mathrm{y}$ (40 MCM/y from Tiberias + $10 \mathrm{MCM} / \mathrm{y}$ from west side of 
Jordan River + 50 MCM/y from Yarmouk River + 42 MCM/y from the eastern side of the Jordan River).

The inflow into the Dead Sea from the western side Wadies of the Dead Sea is equal to about $13 \mathrm{MCM} / \mathrm{y}$, and from the eastern side Wadies is equal to about 147 MCM/y (Zerka Ma'in, Mujeb, Karak, Ibn Hammad, Udheimi Wadies, and from Zara hot thermal springs). Inflows of surface water from the western side of Wadi Araba equal $10 \mathrm{MCM}$, and from the eastern side of the Wadi Araba equal $10 \mathrm{MCM} / \mathrm{y}$ (Salameh and El-Naser, 1999). Then the total amount of the surface water (S) inflow into the Dead Sea from all surface water sources from all sides of the Dead Sea equal about $322 \mathrm{MCM} / \mathrm{y}$.

\subsubsection{Groundwater Flow into the Dead Sea}

The quantity of groundwater discharge into the Dead Sea from the western side equals about $50 \mathrm{MCM} / \mathrm{y}$ (Salameh and El-Naser, 1999), and the flow from the eastern side $90 \mathrm{MCM} / \mathrm{y}$. As well there is about $85 \mathrm{MCM} / \mathrm{y}$ of return flow from irrigation and subsurface flows and saltwater diversions into the Jordan River (Salameh and El-Naser, 1999). Then the total amount of groundwater inflow into the Dead Sea equals to $225 \mathrm{MCM} / \mathrm{y}$.

\subsubsection{Precipitation}

Precipitation $\left(P_{t}\right)$ over the Dead Sea area is simply the total sum of precipitation multiplied by the surface area of the lake. The precipitation is measured by rain gauges spread in the area.

The average precipitation over the Dead Sea is about $92 \mathrm{~mm} / \mathrm{y}$. This average was calculated for a time between 1937 and 1994 (MWI, 1997). The total area of the Dead Sea surface is about $667 \mathrm{~km}^{2}$ (Salameh and El-Nasser, 1999). Then the total precipitation over the whole Dead Sea $\left(P_{t}\right)$ equals:

$P_{t}\left(m^{3} / y\right)=P(m / y) * A\left(m^{2}\right)$

$P_{t}\left(m^{3} / y\right)=92 * 10^{-3} * 667^{*} 10^{6}=61364 * 10^{3} \mathrm{~m}^{3} / \mathrm{y}(61 \mathrm{MCM} / \mathrm{in}$ the year 1995).

\subsubsection{Extractions of the Potash Companies}

Water from the Dead Sea is extracted by the Potash Companies at the Eastern and Western sides of the Dead Sea. The total abstraction rate is about 490 
MCM/y. About $200 \mathrm{MCM} / \mathrm{y}$ of which return to the Dead Sea as brine return flows. That means that the two companies consume about $290 \mathrm{MCM} / \mathrm{y}$ from the Dead Sea water (i.e. $\mathrm{K}=490-200=290 \mathrm{MCM}$ ).

\subsubsection{Evaporation}

In the past only evaporation losses balance the incoming amounts of water into the Dead Sea. But after the potash companies have been established at the both sides of the Dead Sea, water has been extracted and exposed to evaporation in saltpans to extract different kind of salts. Then the net of amount of water remaing in the Dead Sea equals the total amount of incoming water from all sources minus the amount extracted by the Potash Companies. According to (Salameh and El-Naser, $1999)$ the evaporation is $1334 \mathrm{~m}^{3} / \mathrm{y}$ at when the Dead Sea surface area $\left(667 \mathrm{~km}^{2}\right)$

\subsubsection{Final Balance Calculation}

After substituting all incoming and losses amounts in the equation (1) above as following:

$\Delta \mathrm{V}=61+322+225-1334-290$

$\Delta \mathrm{V}=-1016 \mathrm{MCM} / \mathrm{y}$

If this amount is dividing by the surface area of the Dead Sea $667 \mathrm{~km}^{2}(-1016$ $\mathrm{MCM} / 667 \mathrm{~km}^{2}$ ), then the result will be $-152 \mathrm{~cm}$ drop in the Dead Sea level. But the actual drop of the Dead Sea level during last decade averaged only $-80 \mathrm{~cm}$ (Salameh and El-Naser 1999). Then the difference of $72 \mathrm{~cm} / \mathrm{y}$ drops in Dead Sea level, is considered due to additional groundwater discharge into the Dead Sea. The quantity of this additional groundwater flow is equal $\left(0.72 \mathrm{~m} / \mathrm{y}^{*} 667 \mathrm{~km}^{2}\right)=-$ $480.2 \mathrm{MCM} / \mathrm{y}$

According to Salameh and El Nasser (2000) the loss of freshwater into the coastal line of the Dead Sea was $-370 \mathrm{MCM} / \mathrm{y}$ with $0.8 \mathrm{~m}$ dropping in the Dead Sea level for the period of 1994 to 1998.

\subsubsection{Hydrology and Chemical Aspects of the Dead Sea (DS)}

- One of the main features of the Dead Sea is its very high salinity (more than $340 \mathrm{~g} / \mathrm{l})$. While the water salinity in the Atlantic Ocean is $35 \mathrm{~g} / \mathrm{l}$ and it is about $230 \mathrm{~g} / \mathrm{l}$ in the Great Salt Lake in USA. This means that the water 
salanity of the Dead Sea is more nine times than that of other oceans. The density of the water of the Dead Sea is more than $1.237 \mathrm{~g} / \mathrm{cm}^{3}$ (Gavrieli et al., 2005). That is mean no lakes in the world posses such a high salinity and high density as the Dead Sea.

- The salinity of the Dead Sea increases as a result of evaporation with very limited interaction between fresh water and rocks, sand and soils. The fresh water flows into the Dead Sea through the Jordan valley carrying light burden of salts, which is produce from interaction and leaching process. As well there are no out flow and high evaporation process, the inflowing water evaporate leaving salts concentrate in the Dead Sea (Steinhorn and Gat, 1983).

- The water level of the Dead Sea oscillated significantly due to throughout. It is indicated with the historical records (Klein, 1961), Getman and Hetch (2002), Gavrieli and Oren, (2004), Anati and Shasha (1989) and open report APC). The level of the Dead Sea has been continuously dropping since 1860 from 395 to 417.8 in 2005 below sea level as seen in (Fig. 2-3). Figure (2-3) shows that in some years as in 1883, 1895, 1945, 1975, 1980 and 1991-1992 the elevation increased due the high rain.

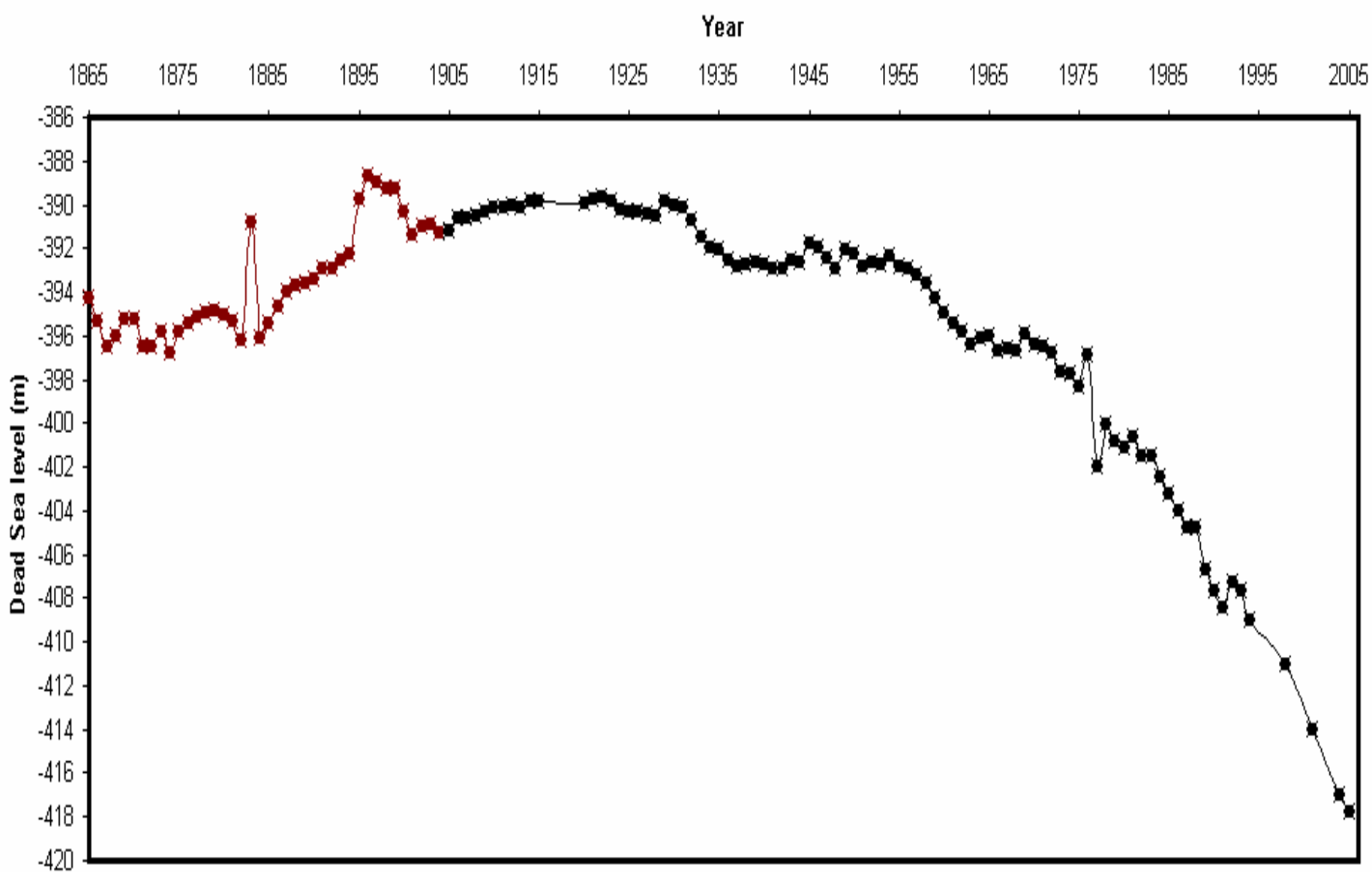

Figure (2-3): Long term changes in the surface level of the Dead Sea 1862-2005 (after Klein, (1961), Getman and Hetch (2002), Gavrieli and Oren (2004) and data from Arab Potash company). 
During the winter of 1980 the surface level rose by almost $1.5 \mathrm{~m}$, and in 19911992 the surface level rose nearly $2 \mathrm{~m}$, due to a large amount ( $1500 \mathrm{MCM})$ of fresh water entered the lake, causing a dilution of the upper $5 \mathrm{~m}$ of the water column to about $70 \%$ of their previous salinity (Beyth et al., 1993). Generally if we exclude the above years the surface level of the Dead Sea has been lowered by an average rate of about $60 \mathrm{~cm} /$ year since 1977 and for the period from 1998 to 2005 the lowering rate has reached about $100 \mathrm{~cm} /$ year.

- The length of the Dead Sea decreased from $80 \mathrm{~km}$ (1978) to about $50 \mathrm{~km}$ now a days, its maximum depth has diminished from $328 \mathrm{~m}$ in 1978 to 316 m (Getman and Hetch, 2002) its surface area was $815 \mathrm{~km}^{2}$ (Neev and Hall 1979) dimensioned to about $643 \mathrm{~km}^{2}$ in 2004 (Rishmawi et al., 2005).

- As well the decreasing in volume of the Dead Sea is naturally followed by an increase in salinity (Gavrieli et al. 1989).

- The separation and gradual drying of the southern basin of the Dead Sea is the most visible impact of declining the Dead Sea level (Asmar and Ergenzinger, 1999).

- The halite began to precipitate from the Dead Sea in 1979 (Steinhorn, 1983). A decrease in halite precipitation rate was observed in the years 1992 to 1995 . This was because of the stratification at these years, which diluted the upper water body and isolated the lower water body (Anati et al., 1995).

\subsubsection{Hydrology of Jordan and the Dead Sea Area}

The highlands in Jordan generally have a semi-arid Mediterranean climate, characterized by cold, wet winter and moderate dry summer. The Temperature in winter reach a few degrees below zero, but in summer the temperature raised to more than $32^{\circ} \mathrm{C}$ with relative humidity of $15-30 \%$. On the other hand climate in the Dead Sea classified as arid climate with hot summer and warm winter. The temperature in summer (June-August) is as high as $45^{\circ} \mathrm{C}$, while in the winter (December- February) the temperature is around $20^{\circ} \mathrm{C}$ during the day and it is fall down to about $5^{\circ} \mathrm{C}$ at night and may reach to zero at some nights in January. The annual average of temperature at the Dead Sea area is about $24^{\circ} \mathrm{C}$.

The precipitation is confined to the winter season and it falls in the form of rainfall. Snow falls two to three times a year over the highlands. The precipitation ranges from about $600 \mathrm{~mm}$ in the northwestern highlands at Ajlun and at the middle part of Jordan decreases gradually to the south to less than $30 \mathrm{~mm}$ in the southeast part and at the Dead Sea. Figure (2-4) shows the annual rainfall distribution at the Dead Sea and the surrounding area. According to Salameh and Bannayan (1993) the 
precipitation is less than $100 \mathrm{~mm}$ over the $80.6 \%$ of the area of Jordan, $12.5 \%$ between 100-200 mm, 3.8\% between 200 and 300, 1.8\% between 300 and $500 \mathrm{~mm}$ and $1.3 \%$ more than $500 \mathrm{~mm}$ annually.

According to Salameh (1996) the average annual amount of precipitation all over Jordan is about 7200 MCM. Figure (2-5) shows the rainfall percentages in Jordan. This precipitation amount is flow down to the Dead Sea and Jordan Valley areas through the Wadies adjacent to these areas. Some of it also infiltrate through the fractures and porosity into the upper aquifers (B2/A7) and Jordan Valley conglomerate deposit which contain a meteoric water flow to the Dead Sea under hydrostatic head. Part of this surface water which flow toward the Dead Sea and Jordan River are collected by dams which established in these areas as Shueib, Kafrain, Al Waleh, Mujeb and Al Karameh before reaching the Dead Sea and Jordan River. The rest of the precipitation drains to the Dead Sea and Jordan River. The deep Aquifers (Kurnub) contain fossil water in the Jordan. These aquifers In the Dead Sea area exposed and receive amount of the precipitation through faults, fractures. Then the meteoric water and fossils water are mixing in the Dead Sea area and seep to the Dead Sea under hydrostatic head.

The Potential evaporation ranges from $2000 \mathrm{~mm} /$ year at the most northwestern edge of the country, to more than $4000 \mathrm{~mm} / \mathrm{year}$ in the Aqaba at the south and Azraq at the East of Jordan. It rates about $2500 \mathrm{~mm} /$ year at the Dead Sea (Salameh and Bannayan 1993).

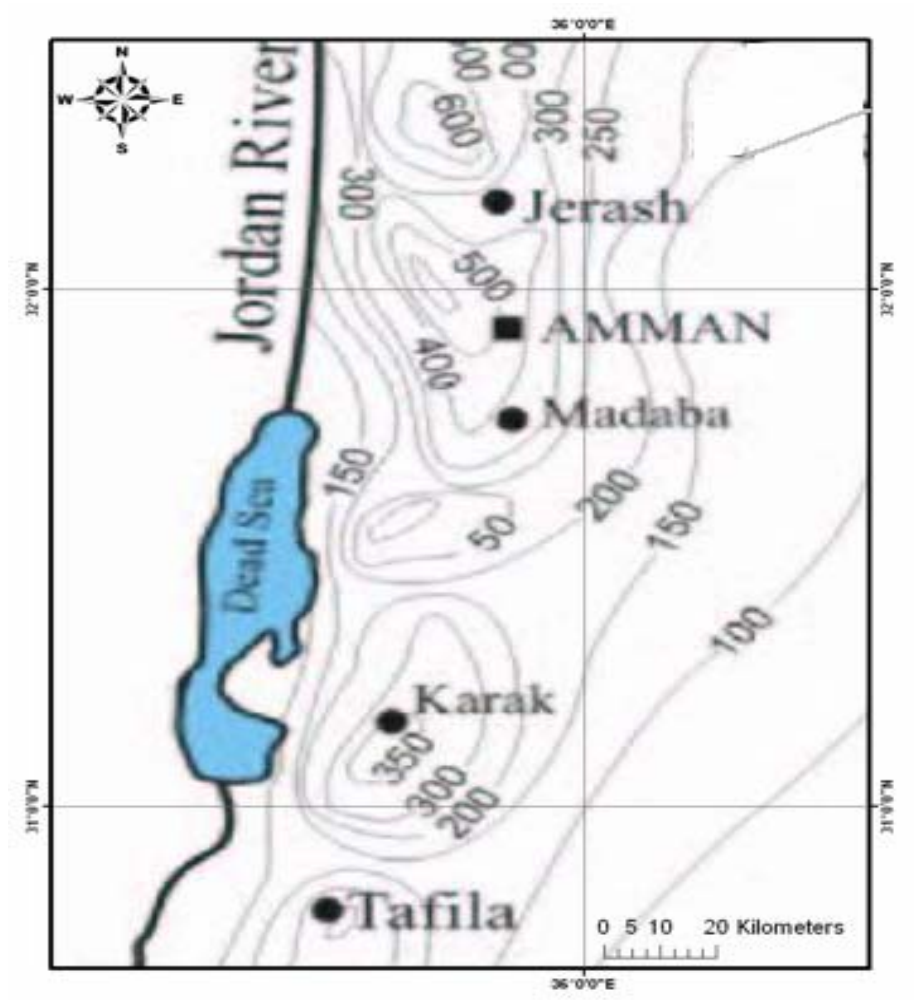

Figure (2-4): Average rainfall annual distribution 


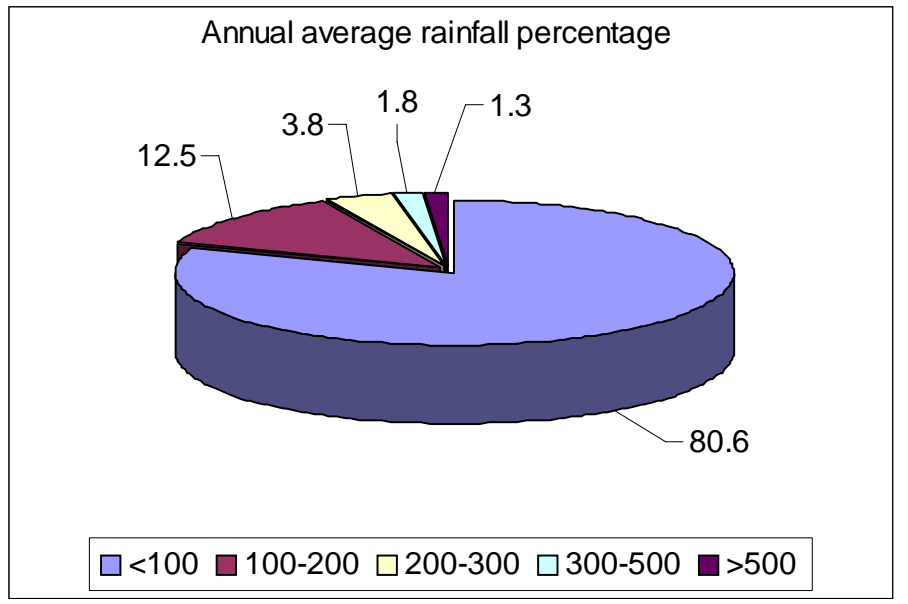

Figure (2-5): Annual average rainfall in percentage

The floodwater from the rainfall and snowfall at the eastern highlands during wintertime and the base flow springs around the area are the main recharge source for the groundwater of the shallow aquifers in the study area. It flows through the Wadies passing adjacent the Dead Sea area.

\subsubsection{Morphology of the Dead Sea Area}

A steep escarpment along the eastern shoreline of the Dead Sea controls the morphology of the Dead Sea area. The difference in the elevation between the Dead Sea Surface and the highlands surrounding the Dead Sea is between 1210 and $1600 \mathrm{~m}$ within of $15 \mathrm{Km}$ horizontal distance to the East of the Dead Sea (Fig. 2-6).

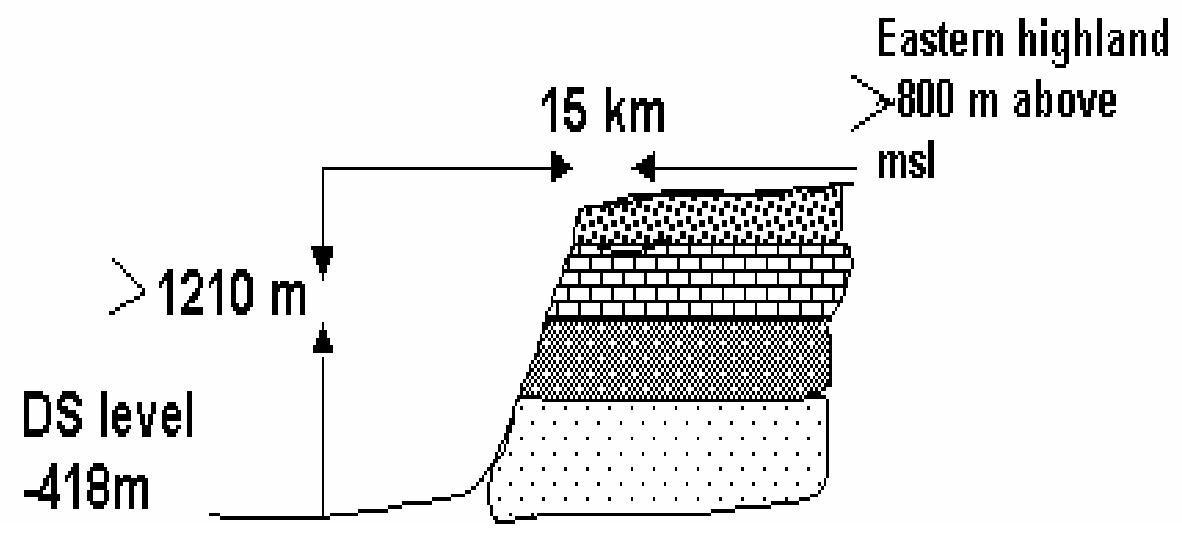

Figure (2-6): Difference of elevations between Dead Sea and the eastern highlands 


\subsubsection{Springs Surrounding the Dead Sea}

There are many springs discharging into the Dead Sea located at the eastern side of the Dead Sea. Some of these springs occurring to the west of the Edhira Monocline and south of the Siwaqa fault. They emerge from Pleistocene and Recent gravels. Among these is Ayn Al Merweh in Ghor Haditha. There are many springs emerge from $\mathrm{F} / \mathrm{H} / \mathrm{S}$ (Fuheis, undifferentiated formation of Hummer Shuaib) as Al Ayn al Bayda, Ayn al Maliha, Ayn Umm Wa'il southern flank of Wadi Mujeb, Ayn Arafat, Ayn Maqbula. There are some springs emerge from Wadi Es Sir $\left(A_{7}\right)$ formation as Buwayra, Ayn al Mughaysil. Some springs issue from Kurnub Sandstone as Ayn Hammam al Hamra in Wadi lbn Hammad (thermal spring).

All the previous springs locate at the south and east of Wadi Mujeb at the coordinate 1073-1097 N and 200-220 E (Palestine Grid). There are some springs which locate at the north and east of Wadi Mujeb at the coordinate 1098-1128 N and 203-220 E (Palestine Grid) as: Ez-Zarqa, El-Qattar, El-Mnya, Ujeirman, Edardor and Ed-Dhib. The temperature of these springs range from 18 to $21^{\circ} \mathrm{C}$. These springs are discharging from the Kurnub (KS) and Ajlun groups along the escarpment area. There are also about 109 thermal springs located in this area. According to Abu Ajamieh, (1980) the temperature of these springs ranges from $34^{\circ} \mathrm{C}$ to $62^{\circ} \mathrm{C}$. Sixty four of these springs located at the northern part of the Wadi Zarka Ma'in. Forty-five springs located at north-south trend in Zara area on the eastern shore of the Dead Sea. All thermal springs in this area issue from upper part of the Kurnub sandstone group (Cretaceous age) (NRA reports) (Fig. 2-7).
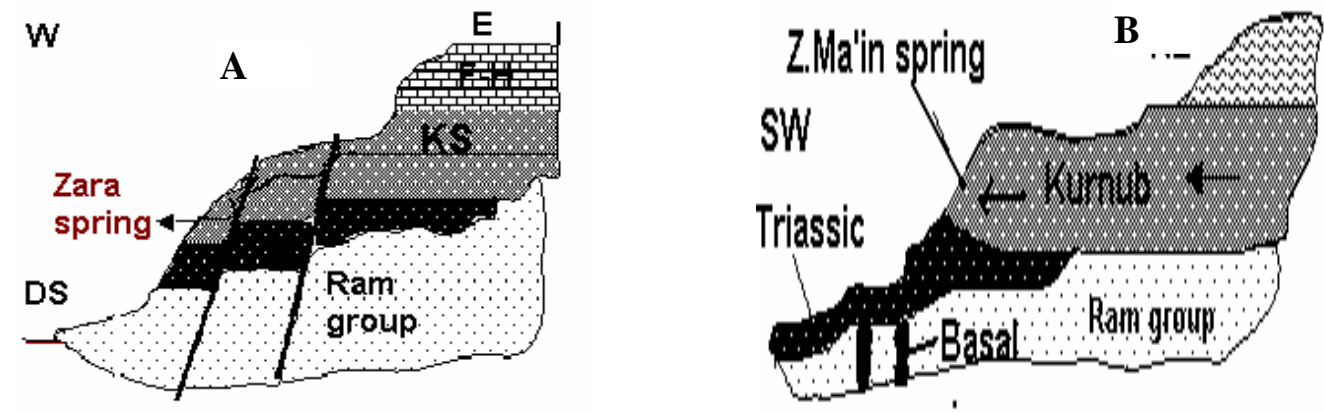

Figure (2-7): Schematic geological cross section of springs in Zara area (A): Zarka Ma'in area (B)

\subsubsection{Sinkholes}

Sinkholes are circular depressions developing in a karst area. They are natural phenomena, which occur in certain geological environments associated with surface, subsurface processes. 
The occurrence of sinkholes and subsidence in Ghor Haditha and Lisan Peninsula areas at the southern Dead Sea basin dates back to about 15 years. The new generations of subsidence in Ghor Haditha and Lisan areas are attributed to the lowering of the Dead Sea level. Tens of collapsed sinkholes formed along the Dead Sea coast. The first opening sinkhole in these areas collapsed during winter 1985, and many others sinkholes followed. The diameter of sinkholes in these areas ranges from a few meters to 20 meters in deepth, and between 1 and 25 meter in diameter. Figure (2-8) shows one of the sinkholes located in the Lisan Peninsula at the eastern coast of the Dead Sea (Jordan side). They present danger to both life and property and they affect fields, houses, roads and salt evaporation ponds. These sinkholes are not randomly scattered on the Dead Sea shores, but tend to occur in clusters (Itamar and Rezmann, 2000). The sinkholes in Ghor Haditha and Lisan are located on the edge of an alluvial fan consisting of coarse clasting sediments and gravels and clay.

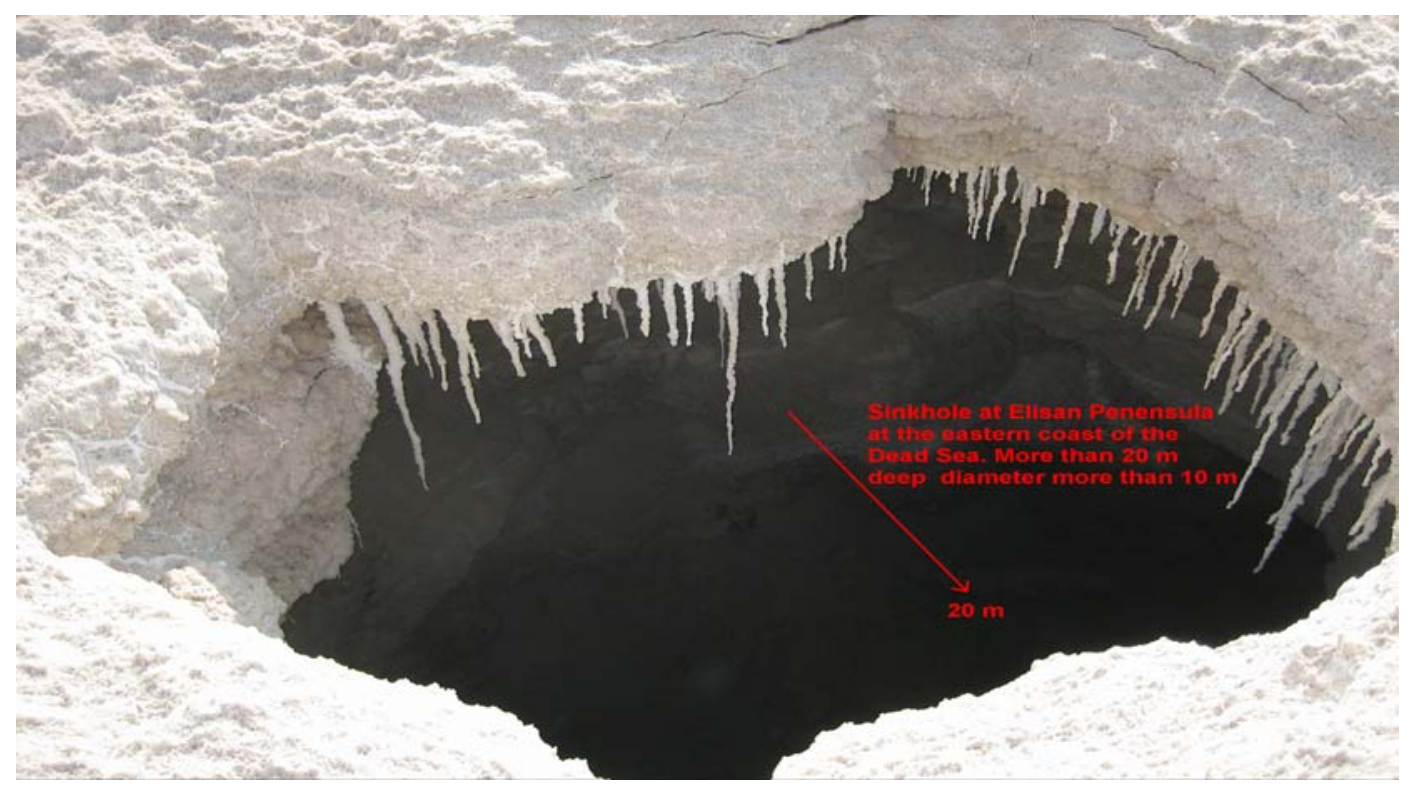

Figure (2-8): One of the sinkholes located in the Lisan Peninsula at eastern coast of the Dead Sea.

The development of the sinkholes is effected by underground mass mobilization; mass transport is cultivated by alluvial. The most generally result from upward subvertical movement of cavities that developed because of the dissolution of underlying layers (Taqieddin et al. 2000). As a consequence of the Dead Sea falling, the interface between the Dead Sea water and the groundwater also is falling. Thus the salt layers surrounded by saturated water in the past in respect to salt, are now exposure to aggressive dissolution by unsaturated groundwater water, which flows to the coast of the Dead Sea through the faults or the joints (Salameh and El-Naser, 2000a, Closson et al. 2005). Then Chemical and physical erosion takes place along the fault and the flow line. Underground voids start to form, creating holes and cavities. As a result numerous sinkholes and subsidences 
appeared in many places along the Dead Sea shoreline. In other words the drop in levels of the Dead Sea and surrounding water table cause decrease of pore pressure and vertical equilibrium of sediments in the vadose zone. These factors are triggering these phenomena (Closson, 2005).

The comparison of the fresh water's conductivity at the apex and tip of the most affected place showed that the concentration of salt increased to $40 \mathrm{~g} / \mathrm{l}$ which confirm the existence of soluble deposits in the underground (Clossen, 2005).

\section{METHODOLOGY}

\subsection{Electrical Conductivity-Temperature with Depth Method}

Electrical conductivity is the ability of a medium to support the flow of an electrical current. It is a measure of the movement of mobile charge carriers to the influence of an electrical field.

Measurement of seawater electrical conductivity is based on the relationship between the ions concentration and the electrical conductivity of seawater. Electrical conductivity device measures the conductivity and temperature. The electrical conductivity anomalies and the temperature distribution are indicators of fresh groundwater discharge. The conductivity in seawater is due to the charged solute ions of dissolved salts in seawater. Thus the electrical conductivity is a property of seawater that varies predictably with both temperature and total ionic concentration (salinity).

Electrical conductivity might be a useful indicator of total dissolved solids because the conduction of current in an electrolyte solution dependent on the ionic concentration. Electrical conductivity-temperature with the depth was used in this study to examine the mixing of the fresh groundwater with Dead Sea water.

Four stations were considered in this study for the electrical conductivitytemperature with depth measurements, along the eastern shoreline of the Dead Sea. These stations were chosen depending on the geology, the structures and the expecting discharge areas which were determined by using the geological, topographical maps and the field trips which were done before starting the measurements. The profiles were carried out for a different depth and chosen relating to the distance away from the eastern shoreline of the Dead Sea.

The air temperature during the measurements was between $40-46^{\circ} \mathrm{C}$ at the Dead Sea area, while the temperature at night decreased to about $30^{\circ} \mathrm{C}$. The inductive 
electrical conductivity sensor (Fig. 3-1) with a cable 100 m length was used for carrying out the electrical conductivity, temperature and depth measurments.

The electrical conductivity and the temperature were measured continuously by using an electrochemical transmitter, which is connected with the sensor and with a portable computer. The depths were measured manually by marking every onemeter of the $100 \mathrm{~m}$ cable length. The sensor was connected tightly with the cable to not loss the sensor in the sea under a pressure at deep-sea water. As well some weight from lead was added in the top of the sensor to keep the sensor diving vertically or with very low deviation to get an exact depth. The electrical conductivity was compensated to $25^{\circ} \mathrm{C}$. The sensor was checked for temperature compensated at $25^{\circ} \mathrm{C}$ by using a standard solution of $\mathrm{MgCl} 2, \mathrm{CaCl} 2, \mathrm{NaCl}, \mathrm{KBr}$ salts as a same of the Dead Sea water composition and a same concentration of the Dead Sea water. The solution was put into a water bath. The temperature was heated up to about $40^{\circ} \mathrm{C}$ and Then it cold back down to about $19^{\circ} \mathrm{C}$. The temperature readings were taken every two degrees. The compensated and noncompensated electrical conductivity reading was found the same at the temperature of $25^{\circ} \mathrm{C}$, which means that the sensor work properly with a temperature compensated. Then the curve of the temperature versus electrical conductivity was issued.

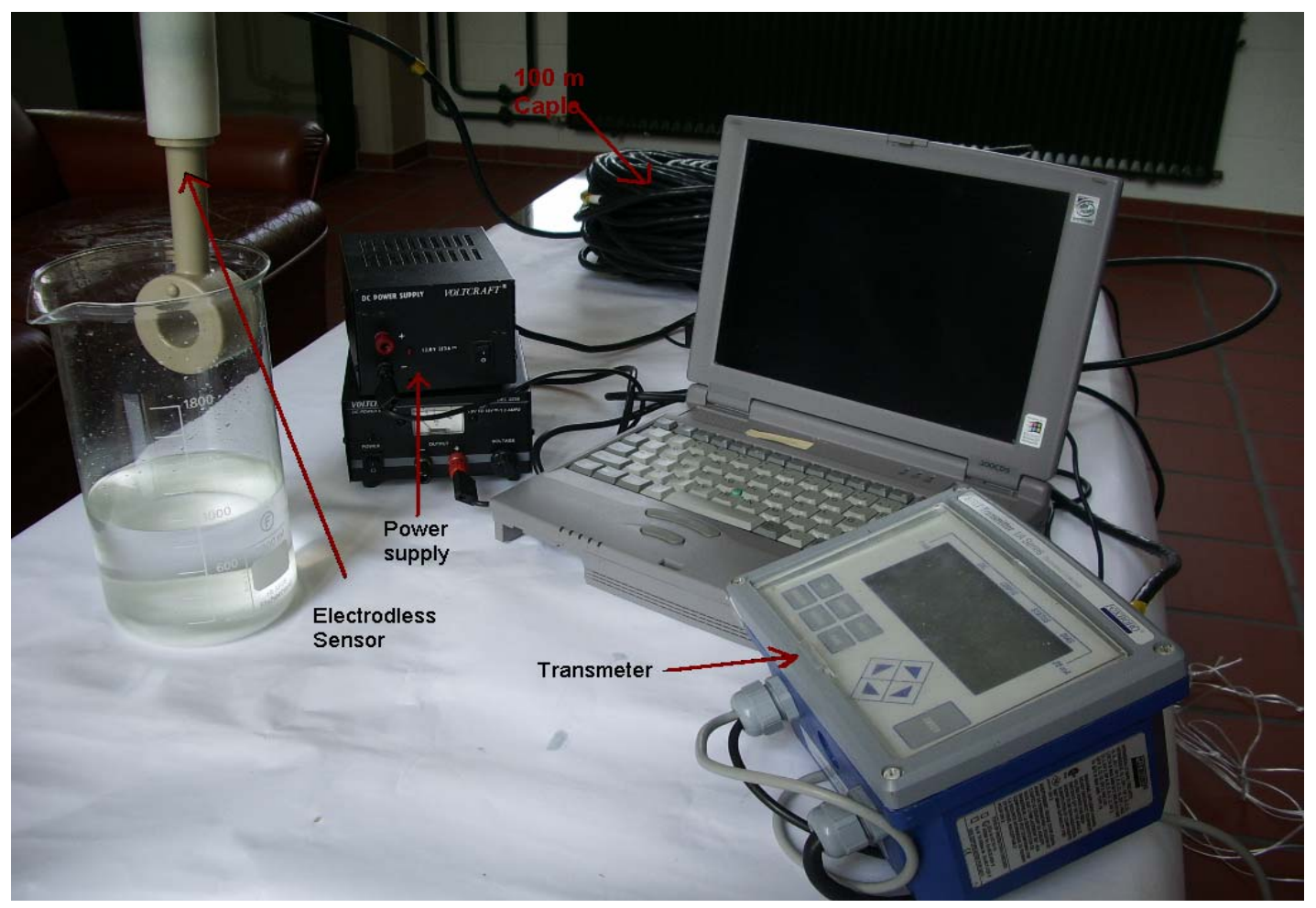

Figure (3-1): Inductive electrical conductivity sensor and its connections 
The samples, which were collected from the different depths and different station into $250 \mathrm{ml}$ plastic containers (section 4.1), were diluted by distilled water as a 1:1 ratio because of salt precipitation at the bottom of the containers were observed after some days. Then the TDS were calculated for these samples using a traditional technique (gravimetric technique).

Gravimetric TDS is defined as the weight of the residue in a known volume of water sample after evaporating all the water from the samples. A $100 \mathrm{ml}$ of wellmixed samples were transferred into pre-weighed $200 \mathrm{ml}$ beakers and evaporated to dryness in an oven at a specific temperature until a constant weight is obtained or until change less than $4 \%$ of previous weight. Then the residual salts were weighed for each sample and the weight result multiply by 2 to get the value of the TDS for each sample.

$\operatorname{TDS}(g / l)=\{((A-B) * 1000) /$ sample volume $(m l)\} * 2$

$A=$ weight of dried residue + beaker

$B=$ weight of empty beaker

The values, which obtained by using gravimetric technique, were compared with the results of the TDS, which were calculating by using equations, related to the electrical conductivity.

The samples were collected from Mujeb area (section 4), were analyzed to determine the anions and cations concentrations in the Dead Sea water. A standard salts contain $\mathrm{MgCl}_{2} \cdot 6 \mathrm{H}_{2} \mathrm{O}, \mathrm{CaCl}_{2} \cdot 2 \mathrm{H}_{2} \mathrm{O}, \mathrm{NaCl}, \mathrm{KBr}$, with a similar ration of the Dead Sea water were mixed with distilled water to get 6 litter salt solution with TDS of $380 \mathrm{~g} / \mathrm{l}$. Two litters of this solution were transferred into a five litters glass container. This solution were used both to calibrate the inductive electrical conductivity sensor, which used in the field and to create a relationship curve between the electrical conductivity and total dissolved solids especially for the Dead Sea and for highly saline solutions. The solution was diluted gradually with adding $25 \mathrm{ml}$ of distilled water to the solution and stirred it for about 15 minutes. The final solution was stirred for about 15 minutes until got a homogeneous solution. Then the electrical conductivity and temperature were measured by using the inductivity conductivity sensor, which used in the filed and the total dissolved solids was calculated.

$\operatorname{TDS}_{\mathrm{f}}(\mathrm{g} / \mathrm{l})=\operatorname{TDS}_{\mathrm{i}} * \mathrm{~F}$

Where TDS $_{\mathrm{f}}$ is the final total dissolved solids after adding $25 \mathrm{ml}$ of distilled water; TDS $_{i}$ is the initial total dissolved solids $(380 \mathrm{~g} / \mathrm{l})$; and $\mathrm{F}$ is the factor fequal volume after adding distilled water / initial volume (2000 $\mathrm{ml})\}$. 
These procedures were repeated for one hundred and thirty times. Then an electrical conductivity versus total solid dissolved curve was created. This curve was used for the electrical conductivity results interpretations- and for calculating the TDS for the Dead Sea water.

Three liters of the previous standard salts solution $(380 \mathrm{~g} / \mathrm{l})$ were transferred into three $2000 \mathrm{ml}$ beakers. Every one letter of the standard solution was transferred to a $2000 \mathrm{ml}$ beaker. These beakers, which include the standard solution, were used for testing the behaviour of the electrical conductivity of these solutions when some more salt adding.

The first beaker was tested for adding different amounts of $\mathrm{MgCl}_{2}$, the second beaker was tested for adding different amounts of $\mathrm{CaCl}_{2} \cdot 2 \mathrm{H}_{2} \mathrm{O}$ and the third beaker was tested for adding different amounts of $\mathrm{NaCl}$. All the beakers and the solutions after every adding were heated to $40^{\circ} \mathrm{C}$ and stirred until all the salt was completely dissolved, then they were put in a water bath thermostat until reach a temperature of $25^{\circ} \mathrm{C}$ then the electrical conductivity was measured at each salt adding. The amounts of $\mathrm{MgCl}_{2}$ salts adding were 10,15, 20 and 25 grams. The amounts of $\mathrm{CaCl}_{2}$ salts adding were 10,20,30,40,50 and 60 grams. The amounts of $\mathrm{NaCl}$ salts added to the third beaker were 5, 10, 15 and 20 grams. The density for the final three solutions of three salts and the density of the initial solution were measured using pincometer technique by taking a known volume from the solutions and weighed them. Then a relationship between the densities and the total dissolved solids of each salt were plotted.

\subsection{Chemical Tracer (Radon-222) Method}

Standard sampling and analysis techniques may apply measurement of radon concentrations in the water column. A special care must be taken for measurement radon-222 (Broecker et al. 1968, Mathieu et al. 1988).

Radon-222 is a useful geochemical tracer for analyzing groundwater discharge due to facts that are radon-222 is greatly enriched in groundwater relatively to seawater by three or four order. It can be measured at very low concentration (Cable, 1996, Lambert and Burnett, 2003,).

The hydrographic characteristics were obtained from the previous section (3.1) conductivity, temperature, and depth readings at each water collection station. Water samples for ${ }^{222} \mathrm{Rn}$ analysis were collected in $50 \mathrm{ml}$ evacuated gas bubbler (Fig. 3-2) using a small submersible pump and a rubber hose that drew water from depth directly into the bubblers.

Radon-222 gas was extracted and counted using RAD-7 device manufactured by (Durridge Co. Inc) (Fig. 3-2b). 
The sample was spurge by air pumped in by the RAD7 internal pump. The outflowing gas was dried with a drier before entering the RAD7 device in order to keep the humidity into the device always less than $10 \%$, which is required to obtain an optimum radon-222 concentration result, then the radon start for counting.
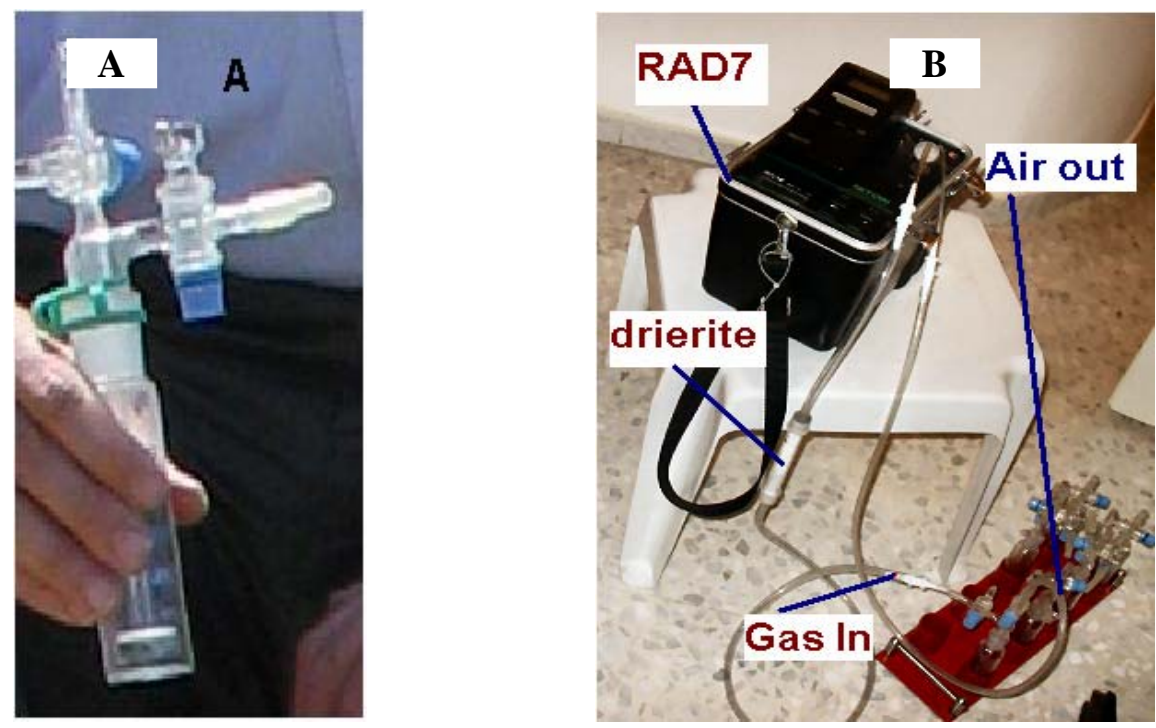

Figure (3-2): (A) Photo of the gas bubbler

(B): Photo of the RAD7 device

The starting counting time was written down for each sample. This time was used latter for the decay-corrected back to the time of sampling.

Each sample was purging for about 40 minutes to account all the radon gas in the samples.

Then the reading of radon-222, obtained from the Device and the volume of water in the radon bubbler were written down.

The radon-222 concentrations values were decay-corrected back to the time of sampling in order to assess the in situ radon concentrations. They were calculated for all the samples by using the following formula:

$F=1 / \exp \left(-2.097 * 10^{-6 *} \Delta t\right)$.

Where $F$ is the radon decay corrected-back factor, $\Delta t$ is the difference of time between the analysis time and sampling time (in second).

The factor of volume was calculated for each sample by using the formula 
$\mathrm{V}_{\mathrm{F}}=900 / \mathrm{V}_{\mathrm{I}}$. Where $\mathrm{V}_{\mathrm{F}}$ is the volume correction factor, $\mathrm{V}_{\mathrm{I}}$ (in $\mathrm{ml}$ ) is the initial volume of the sample in the gas bubbler (between 30 and $35 \mathrm{ml}$ ), and $900 \mathrm{ml}$ is the constant number storage in the RAD7 device.

The actual radon concentration for each sample was calculated by using the following equation:

${ }^{222} \mathrm{Rn}=\left(\mathrm{Rn}_{(\mathrm{RAD7})}{ }^{*} \mathrm{~F}{ }^{*} \mathrm{~V}_{\mathrm{F}}\right) / 1000$. Where $\mathrm{Rn}$ (RAD7) is the radon reading got direct from RAD7 device.

As well many sample were taken from the springs and seepage at the surrounding the Dead Sea area. The ${ }^{222} \mathrm{Rn}$ concentrations were measured and calculated for each sample using the same procedures and equations that mentioned above.

The diffusion of radon from bottom sea sediments was measured by using technique that described by (Corbett et al., 1998). About $80 \mathrm{~g}$ of sediment and about $200 \mathrm{ml}$ of water was but in the flasks and sealed very well for about 30 days. After the thirty days equilibration period the radon-222 was measured for each sample.

The temperature at the sea surface was measured by using the FOXPORO device, which was used for the electrical conductivity measurements. The radon concentration at the atmosphere was estimated.

The porosity was calculated and the Bulk density was measured for some samples. The results were used for estimating the radon diffusion from the sediments.

The radon-222 inventory, atmospheric evasion, and diffusive flux from the sediments, radon-222 productions were calculated by using different equations (details in section 5.2).

After measurments were completed the approach of (Burnett and Dulaiova, 2003 and Lambert and Burnett, 2003) was followed as the following concepts:

- Calculate the ${ }^{222} \mathrm{Rn}$ inventory for the water column by integrating the ${ }^{222} \mathrm{Rn}$ concentration with depth in the water column.

- Using a radon budget approach for estimating and accounting of any ${ }^{222} \mathrm{Rn}$ inputs and outputs to the investigate area by other processes "such as loss to atmosphere, inputs from sediments, Ingrowths from ${ }^{226} \mathrm{Ra}$ dissolved in water column)" (Fig. 3-3).

- Calculate the total input flux of ${ }^{222} \mathrm{Rn}$ to balance the measured inventories. 
- Measure the ${ }^{222} \mathrm{Rn}$ concentration in the groundwater around the investigate area.

- Estimate advection rate by dividing the radon flux by the radon activity in the groundwater.

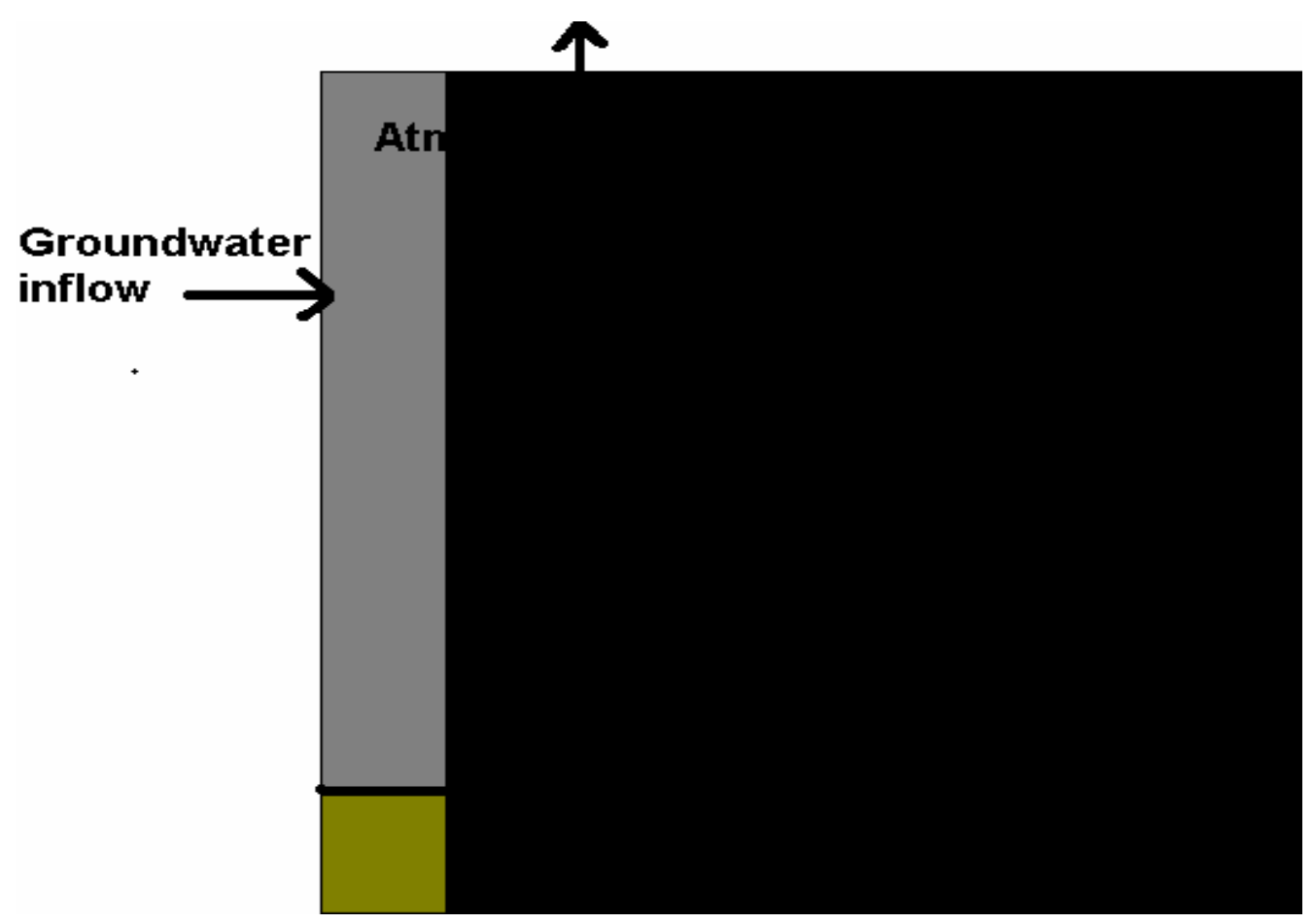

Figure (3-3): One-dimensional model of sources and losses of ${ }^{222} \mathrm{Rn}$ in a wellmixed coastal environment.

\subsection{Thermal Infrared Imagery (TIR) Method}

The base of the thermal fingerprint is based on a pronounced thermal gradient between the groundwater and ambient surface conditions. The thermal infrared Imagery is an effective method to quickly assess large-scale areas and acquire information about specific locations of groundwater discharge.

This study exploited an idea of using temperature differences between groundwater and surface water in the Dead Sea to delineate zones of comprehensive groundwater-sea surface water exchanges. The groundwater temperature is relatively stable and it is as an average temperature of the area, while the temperatures of the surface water are changeable with changing the seasons. Thermal infrared only measures surface temperatures so its application is limited to the intertidal zones and above (Ballestero et al., 2004). 
The thermal infrared imagery was carried out as the following procedures:

- The flight paths were drawn down on a geo-referenced Land7 satellite image to determine the coordinates for each flight line at the office.

- The optimal flight elevation from the standard sea level was determined in order to obtain the require resolution, the overlapping percentage and the ground coverage of the images.

- An initial site characterization was performed and the study area was reviewed for existing land use and irrigation areas.

- The thermal camera was prepared and calibrated for the sky temperature, the humidity and the sharpness.

- Finally the thermal camera was fixed at the bottom of the plane and the GBSs stations were also fixed.

After carrying out the Imagery many steps for interpretation and processing were carried out.

(a) Identification and cataloguing of discharge zones by thermal Imagery,

(b) Geological field investigations based on the identification of potential groundwater discharge zones, e.g. fractured zones, lineaments,

(c) Each images strip was calibrated relatate to flight elevation, water temperature, atmospheric temperature at flight height and relative humidity by using the camera software as shown in (Fig. 3-5). 

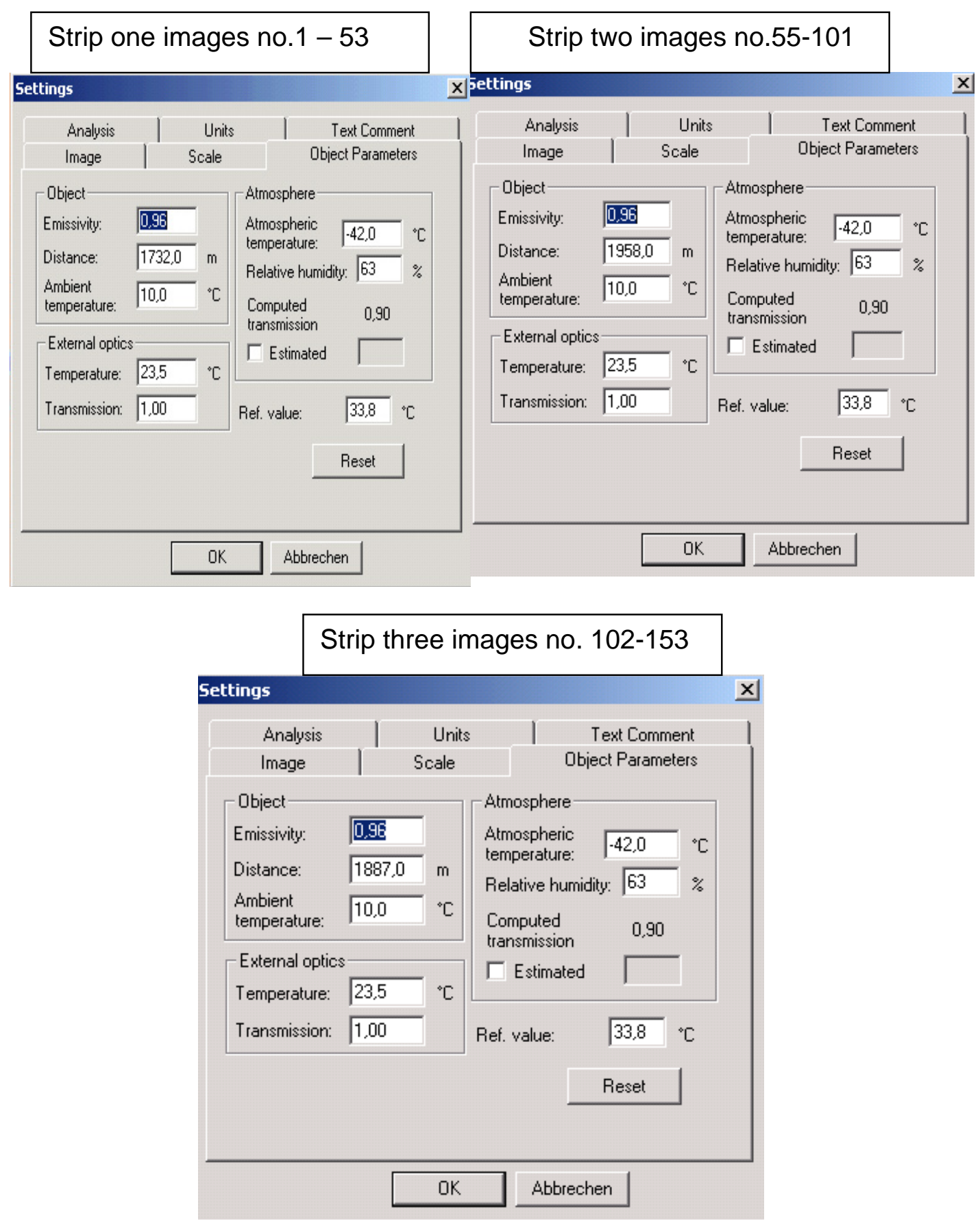

Figure (3-4): Settings in ThermaCamResearcher for flight lines

\subsection{Electromagnetic Radiation (EMR) Method}

This method is depending on the measurement of natural pulsed low frequency electromagnetic radiation (EMR) signals. Generally in geoscience the detection and analysing of these signals can assist to conceive and understand deformation 
processes. The electromagnetic radiation starts during crystal deformation superior to and at the same time of the nucleation phase of nanocracks. Where the more fractures are formed the more electromagnetic Pulses are emitted. The emission and radiaton direction is normal to the fracture surfaces because of the polarization (Obermeyer, Personal commencation). The instrument, which will use for performing these measurements named Cerescope (Fig.3-5). The Cerescope is a scientific instrument for detection and registration of transient pulses of electromagnetic radiation (EMR), which produced by nanofractrures, and by piezoelectric, turboelectric or pyroelectric effects (Bahat et al. 2005).

This method was used to identify the underground active faults and fractured zone along the Dead Sea. These faults and joints consider as a zones of weekness for the groundwater discharge along the shoreline. As well the sinkholes could be identifying by using this method.

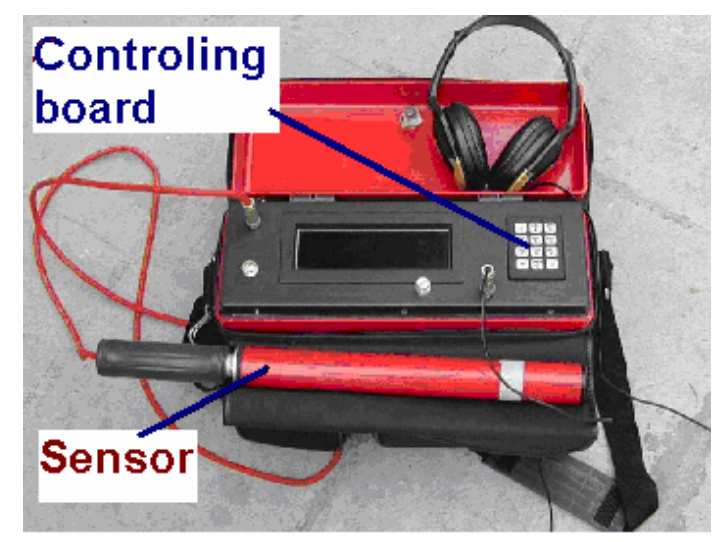

Figure (3-5): Electromagnetic radiation sensor (Cerescope)

\subsection{Geological Model of the Dead Sea Area}

The geology of the Dead Sea is quite complicated. It includes both unconsolidated superficial geological formations and bedrock outcrops. The area is highly faulted and folded with axes extending NE-SW. The bedrock is typically highly fractured at the surface extending in the subsurface for many meters.

Different geologic cross sections were constructed parallel to the Dead Sea shores direction N-S and others E-W and NE-SW. Figure (3-6) shows the locations of these cross sections exposed on the geological map. That is expected to assist in understanding the hydrological and hydrogeological aspects of the area adjacent to the Dead Sea.

Symbols and coordinates of the geological cross sections are given in table (3-1). 
Table (3-1): Symbols and coordinates of the geological cross sections.

\begin{tabular}{|c|c|c|c|c|c|c|c|c|}
\hline $\begin{array}{l}\text { Section } \\
\text { symbol }\end{array}$ & East & North & $\begin{array}{l}\text { Section } \\
\text { symol }\end{array}$ & East & North & $\begin{array}{l}\text { Section } \\
\text { symbol }\end{array}$ & East & North \\
\hline $\begin{array}{l}A-A^{\prime} \\
A \\
A^{\prime}\end{array}$ & $\begin{array}{l}35^{\circ} 34^{\prime} 30^{\prime \prime} \\
35^{\circ} 45^{\prime} 00^{\prime \prime}\end{array}$ & $\begin{array}{l}31^{\circ} 37^{\prime} 30^{\prime \prime} \\
31^{\circ} 38^{\prime} 30^{\prime \prime}\end{array}$ & $\begin{array}{l}D-D^{\prime} \\
D \\
D^{\prime}\end{array}$ & $\begin{array}{l}35^{\circ} 34^{\prime} 58^{\prime \prime} \\
35^{\circ} 45^{\prime} 00^{\prime \prime}\end{array}$ & $\begin{array}{l}31^{\circ} 28^{\prime} 40^{\prime \prime} \\
31^{\circ} 29^{\prime} 57^{\prime \prime}\end{array}$ & $\begin{array}{l}\mathrm{G}-\mathrm{F}^{\prime} \\
\mathrm{G} \\
\mathrm{F}^{\prime}\end{array}$ & $\begin{array}{l}35^{\circ} 33^{\prime} 30^{\prime \prime} \\
35^{\circ} 45^{\prime} 00^{\prime \prime}\end{array}$ & $\begin{array}{l}31^{\circ} 33^{\prime} 30^{\prime \prime} \\
31^{\circ} 42^{\prime} 42^{\prime \prime}\end{array}$ \\
\hline $\begin{array}{l}\text { B-B'-B"'- } \\
\text { B'"' }^{\prime} \\
\text { B } \\
\text { B' }^{\prime} \\
\text { B' }^{\prime \prime} \\
\text { B'" }^{\prime \prime}\end{array}$ & $\begin{array}{l}35^{\circ} 31^{\prime} 30^{\prime \prime} \\
35^{\circ} 32^{\prime} 56^{\prime \prime} \\
35^{\circ} 34^{\prime} 30^{\prime \prime} \\
35^{\circ} 44^{\prime} 48^{\prime \prime}\end{array}$ & $\begin{array}{l}31^{\circ} 17^{\prime} 10^{\prime \prime} \\
31^{\circ} 16^{\prime} 00^{\prime \prime} \\
31^{\circ} 15^{\prime} 22^{\prime \prime} \\
31^{\circ} 15^{\prime} 30^{\prime \prime}\end{array}$ & $\begin{array}{l}F-F^{\prime} \\
F \\
F^{\prime}\end{array}$ & $\begin{array}{l}35^{\circ} 35^{\prime} 00^{\prime \prime} \\
35^{\circ} 45^{\prime} 00^{\prime \prime}\end{array}$ & $\begin{array}{l}31^{\circ} 42^{\prime} 30^{\prime \prime} \\
31^{\circ} 42^{\prime} 42^{\prime \prime}\end{array}$ & $\begin{array}{l}M-D^{\prime} \\
M \\
D^{\prime}\end{array}$ & $\begin{array}{l}35^{\circ} 33^{\prime} 00^{\prime \prime} \\
35^{\circ} 45^{\prime} 00^{\prime \prime}\end{array}$ & $\begin{array}{l}31^{\circ} 20^{\prime} 28^{\prime \prime} \\
31^{\circ} 29^{\prime} 57^{\prime \prime}\end{array}$ \\
\hline $\begin{array}{l}\mathrm{C}-\mathrm{C}^{\prime} \\
\mathrm{C} \\
\mathrm{C}^{\prime}\end{array}$ & $\begin{array}{l}35^{\circ} 33^{\prime} 00^{\prime \prime} \\
35^{\circ} 36^{\prime} 30^{\prime \prime}\end{array}$ & $\begin{array}{l}31^{\circ} 15^{\prime} 00^{\prime \prime} \\
31^{\circ} 30^{\prime} 00^{\prime \prime}\end{array}$ & $\begin{array}{l}\text { G-G' } \\
\text { G } \\
G^{\prime}\end{array}$ & $\begin{array}{l}35^{\circ} 33^{\prime} 30^{\prime \prime} \\
35^{\circ} 45^{\prime} 00^{\prime \prime}\end{array}$ & $\begin{array}{l}31^{\circ} 33^{\prime} 30^{\prime \prime} \\
31^{\circ} 33^{\prime} 31^{\prime \prime}\end{array}$ & $\begin{array}{l}C^{\prime}-C^{\prime \prime} \\
C^{\prime} \\
C^{\prime \prime}\end{array}$ & $\begin{array}{l}35^{\circ} 36^{\prime} 30^{\prime \prime} \\
35^{\circ} 38^{\prime} 00^{\prime \prime}\end{array}$ & $\begin{array}{l}31^{\circ} 30^{\prime} 00^{\prime \prime} \\
31^{\circ} 46^{\prime} 00^{\prime \prime}\end{array}$ \\
\hline
\end{tabular}

Geologic cross sections cover a large extends of the Dead Sea area, which is divided in three parts. The first one extends from the northern end of the Dead Sea in Sweimah area to Zarka Ma'in fault line. The second part extends between Zarka Ma'in fault line and Siwaqa fault and the third one extends from the Siwaqa fault to end southern of the Dead Sea. 


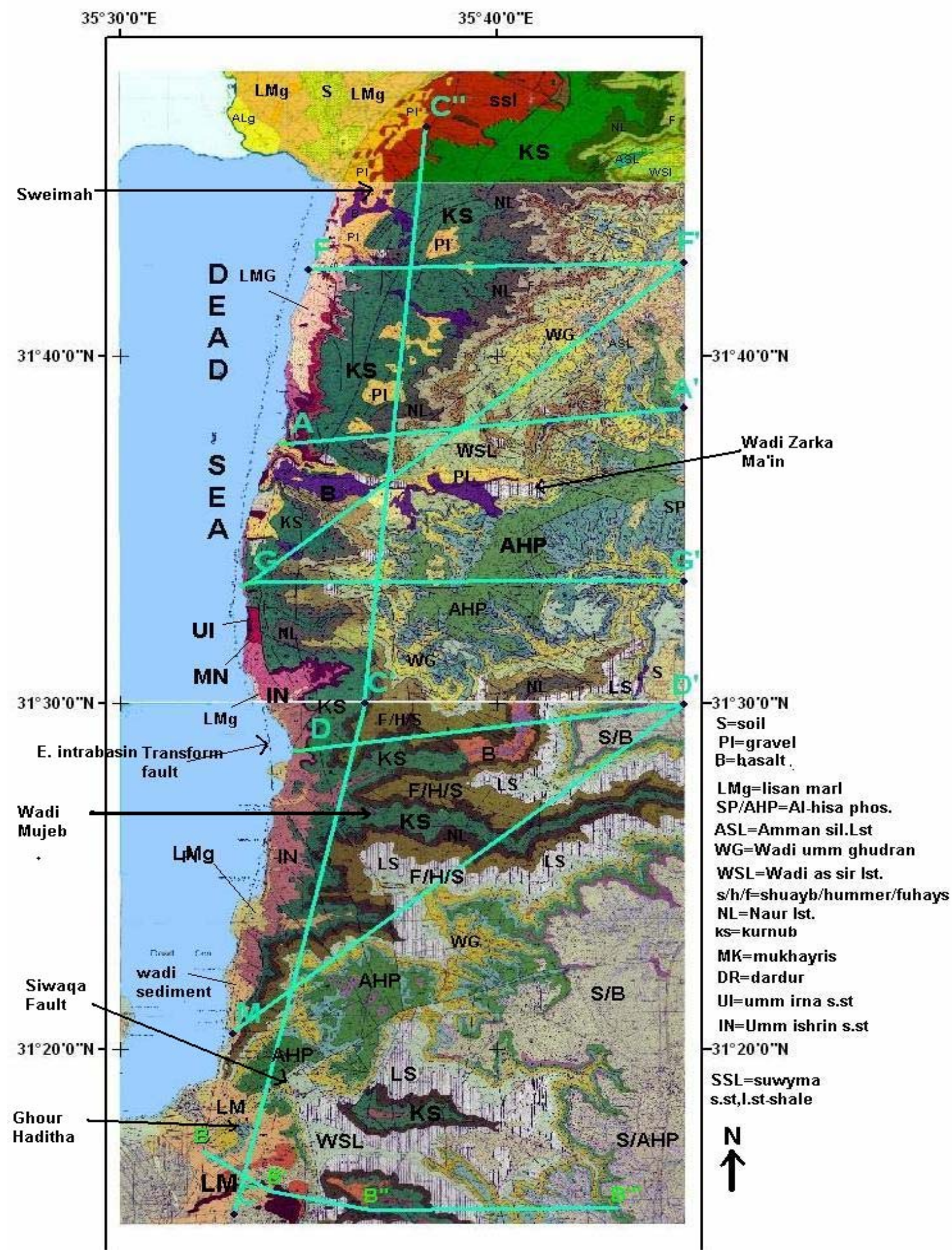

Figure (3-6): Locations of geologic cross-sections exposed on the geological map. 


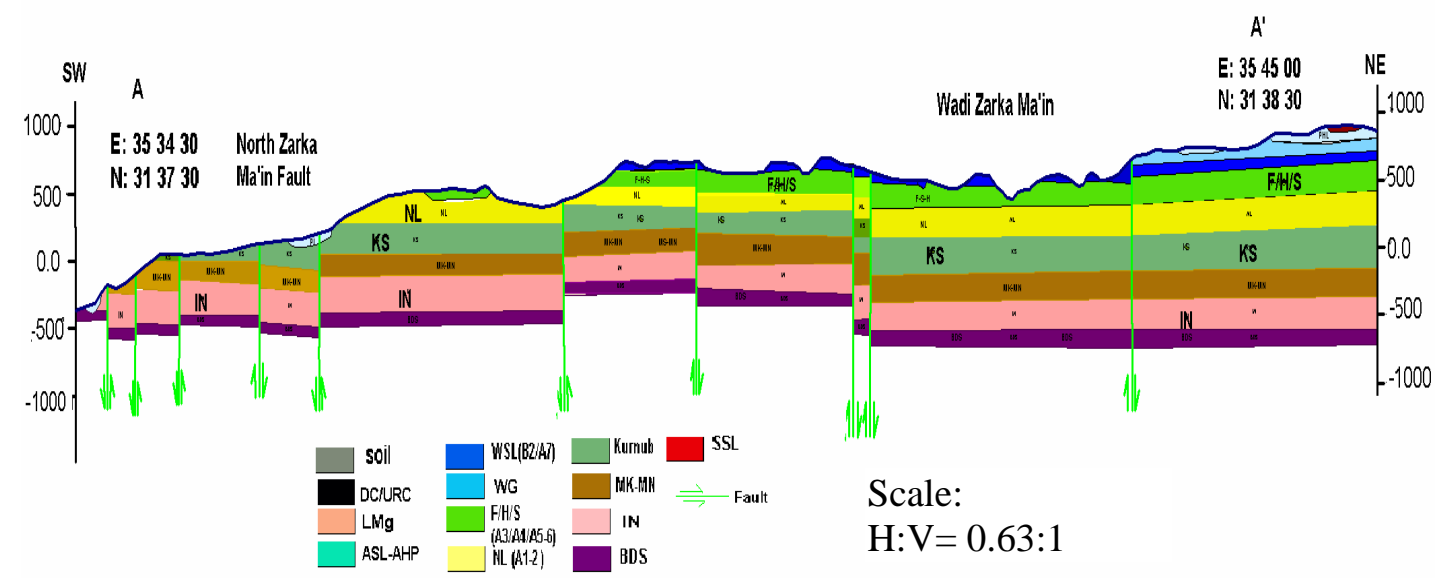

Figure (3-7): Geological cross section A-A' in north of Zarka Ma'in fault

The geological cross section A-A' is located at the north of Zarks Ma'in fault. The direction of this section is SW-NE (Fig. 3-7). The section shows that the layers slope gently toward Wadi Zarka Ma'in. Kurnub sandstone aquifer (KS) cropps out at the SW part of the section north of Zarka Ma'in fault. The upper aquifer $\left(B_{2} / A_{7}\right)$ is cropping out along the section and missing farther to the SW direction. The expected groundwater flow direction is from NE toward Wadi Zarka Ma'in and it continues to the SW toward the Dead Sea.

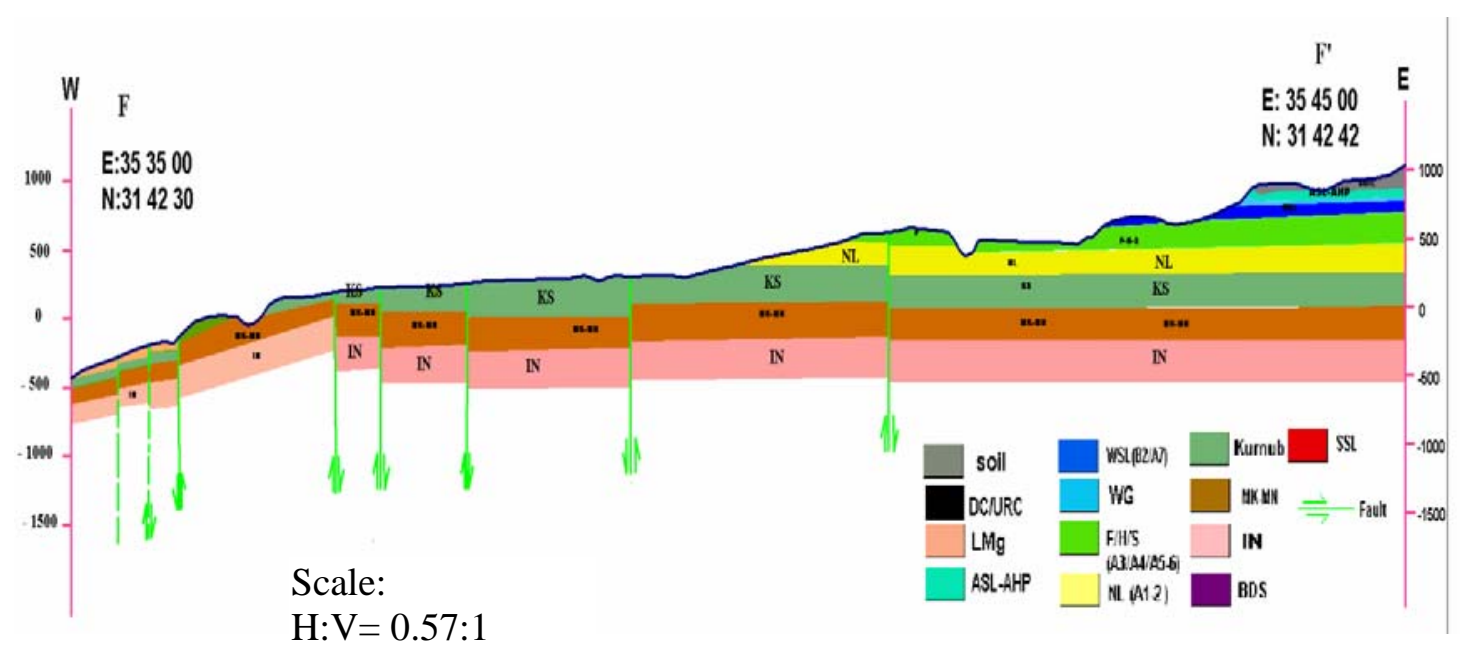

Figure (3-8): Geological cross section F-F` in Sweimah area 
The geology of Sweimah area is described by using the geological cross section F$F^{\prime}$ which is located at this area with direction W-E (Fig. 3-8). The cross section shows that the geological strata of Sweimah area dipps gently from east to west, but they are dipping with high increased slope at the west end of the cross section toward the Dead Sea. The cross section shows that the lower aquifer (KS) is cropping out in the west of the cross section. The groundwater might be flowing from the east to the west toward the Dead Sea relating to the dip direction of the layers.

The geology of the area, which is located between Wadi Mujeb and Zarka Ma'in, is represented by the geological cross sections D-D' and G-G' (Fig. 3-9), and (Fig. 310) respectively. The direction of the geological cross section $D-D$ ' is SW-NE. It represents the geology of the area located to the north of Wadi Mujeb. The cross section shows that the eastern part of the section is highland with horizontal geological layers covered with a layer of soil. Then the layers are sharply removed by erosion toward the Wadi Hidan to the west of the section. The upper aquifers $\left(\mathrm{B}_{2} / \mathrm{A}_{7}\right)$ are missing and the lower aquifer (KS) is cropping out at Wadi Hidan and Wadi An Nimer. The lower aquifer Umm Ishrin (IN) is cropping out southwest of Wadi An Nimer adjacent to the Dead Sea. The groundwater direction is from NE to SW to Wadi Hidan and Wadi An Nimer then toward the Dead Sea.

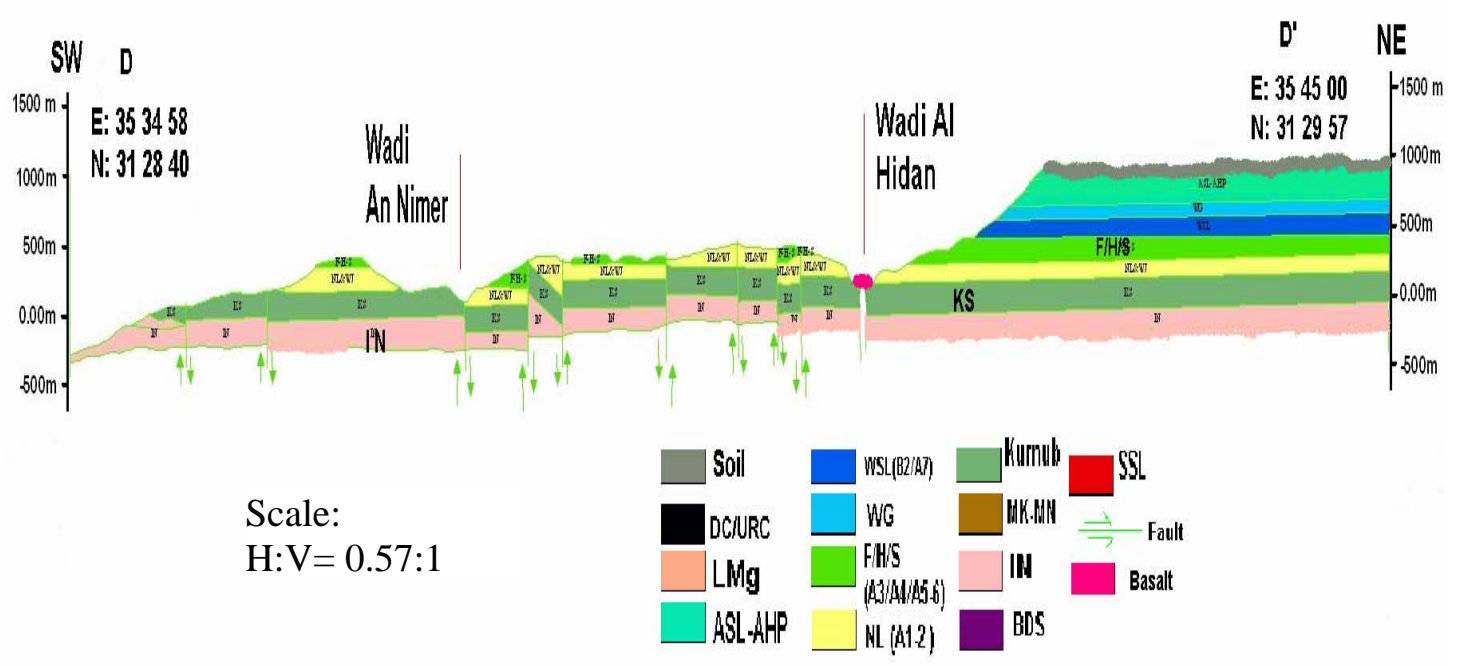

Figure (3-9): Geological cross section D-D`located north of Mujeb

The direction of the cross section G-G' is W-E and it shows that strata dip toward Wadi Arya and Wadi Hidan to the west of the section. They are uplifted again to the west of these Wadies and so the upper aquifer is cropping out and then missing farther to the west. Thereafter the upper layers are eroded and the lower aquifer is cropping out adjacent to the Dead Sea. The expected groundwater flow direction is from the eastern highland toward Wadi Arya and Wadi Hidan then continues toward the Dead Sea at the west of the section. 


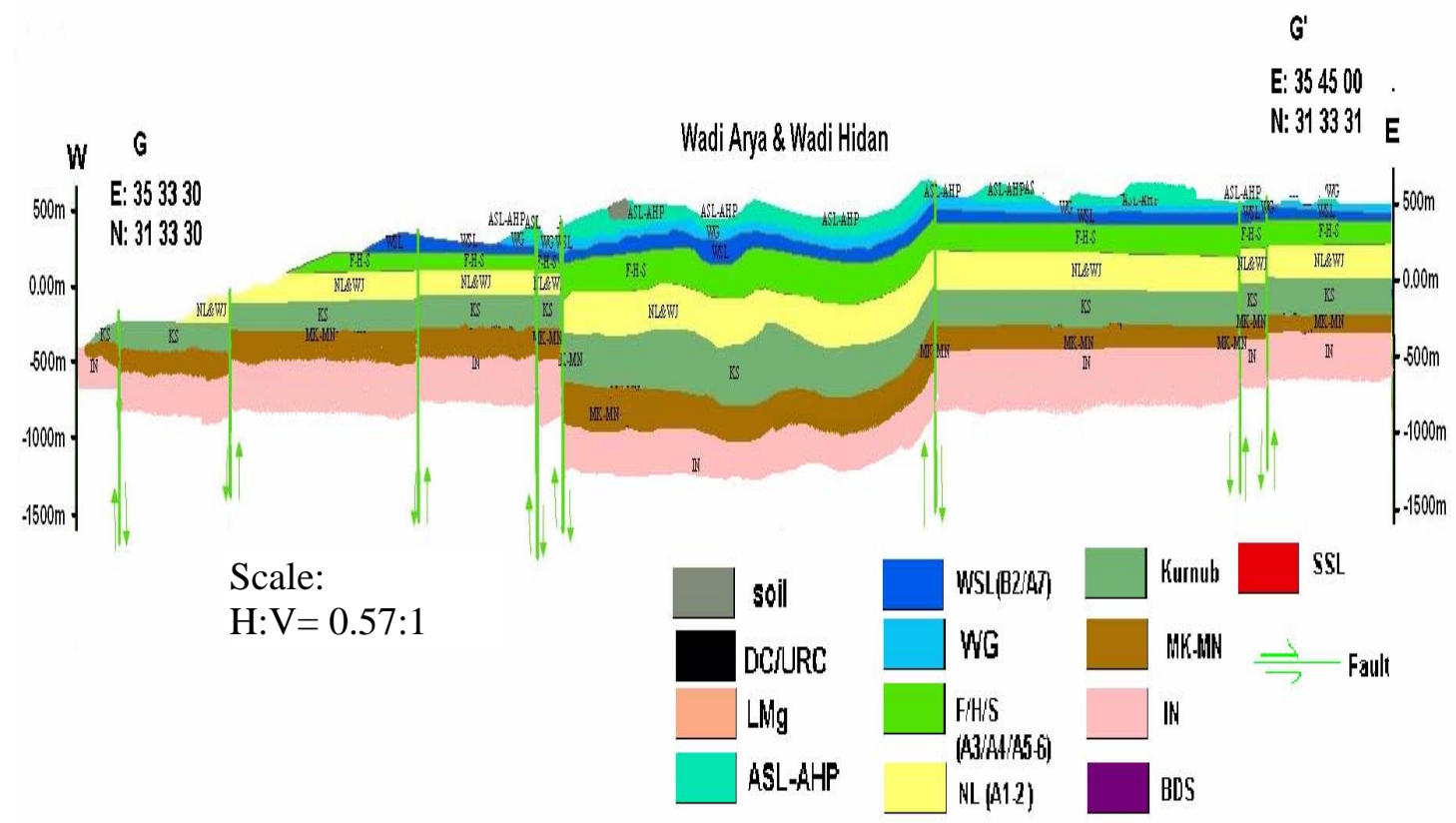

Figure (3-10): Geological cross section G-G' located in north Wadi Mujeb

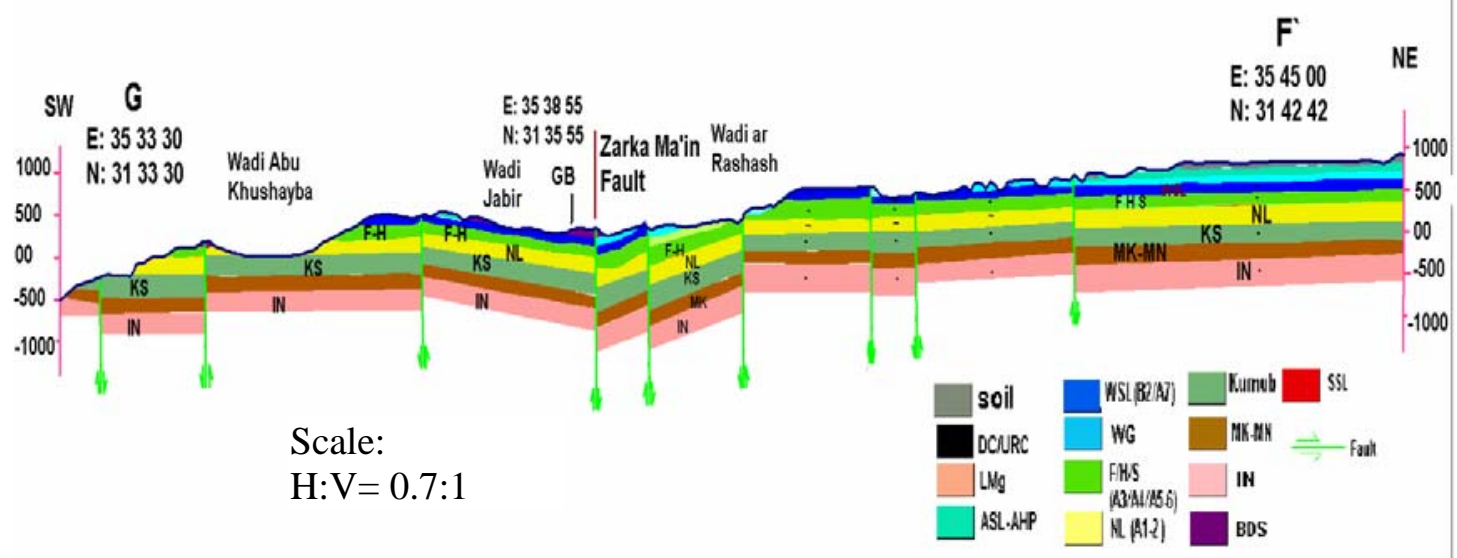

Figure (3-11): Geological cross section G-F’ crossed Wadi Zarka Ma'in 
To understand the effect of Wadi Zarka Ma'in Fault on the geology in the area surrounding this fault the geology cross section G-F` (Fig. 3-11) was contructed in the SW-NE direction crossing this fault. The cross section shows that the layers are dipping toward Wadi Zarka Ma'in from both NE and SW directions. The groundwater might be flowing from NE and SW toward the Wadi Ar Rashash and Wadi Jaber which are located to both sides of Wadi Zarka Ma'in fault. From there it might be flowing to Wadi Zarka Ma'in then it continues to the west toward the Dead Sea. Also, a surface and groundwater might be flowing to Wadi Abu Khushiba at the southwest of the cross section and then might be discharging into the Dead Sea to the west.

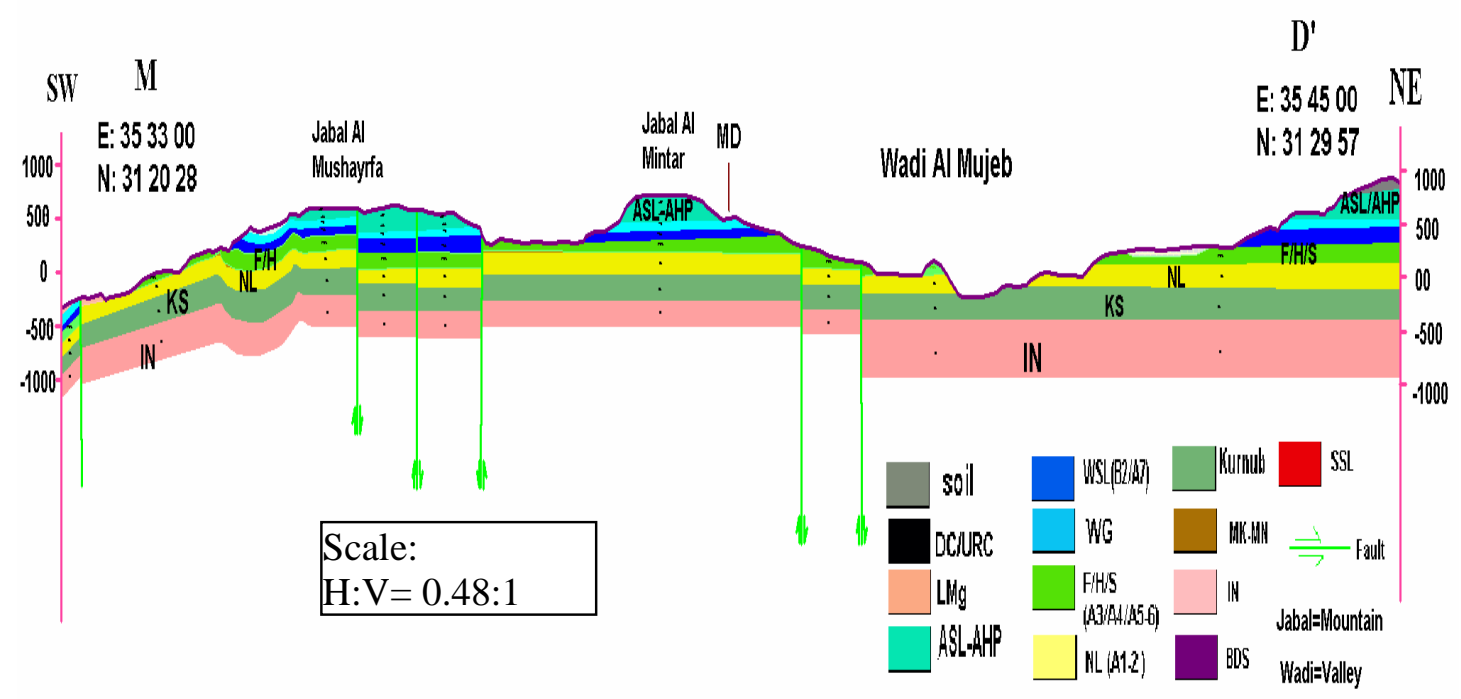

Figure (3-12): Geological cross section M-D`crossed Wadi Mujeb

The geological cross section M-D` (Fig. 3-12) was drawn to understand the geology of Wadi Mujeb. This cross section is SW-NE direction crossing Wadi Mujeb. The cross section shows that the geological strata are eroded and the topography dipps toward Wadi Mujeb from both NE and SW directions. At the uplifted western side of the cross section the layers are dipping to SW direction. The lower aquifer (KS) crops out in Wadi Mujeb. The surface and groundwater might be flowing toward Wadi Mujeb. At the uplifted side of the cross section the groundwater might flowing in SW direction toward the Dead Sea. 


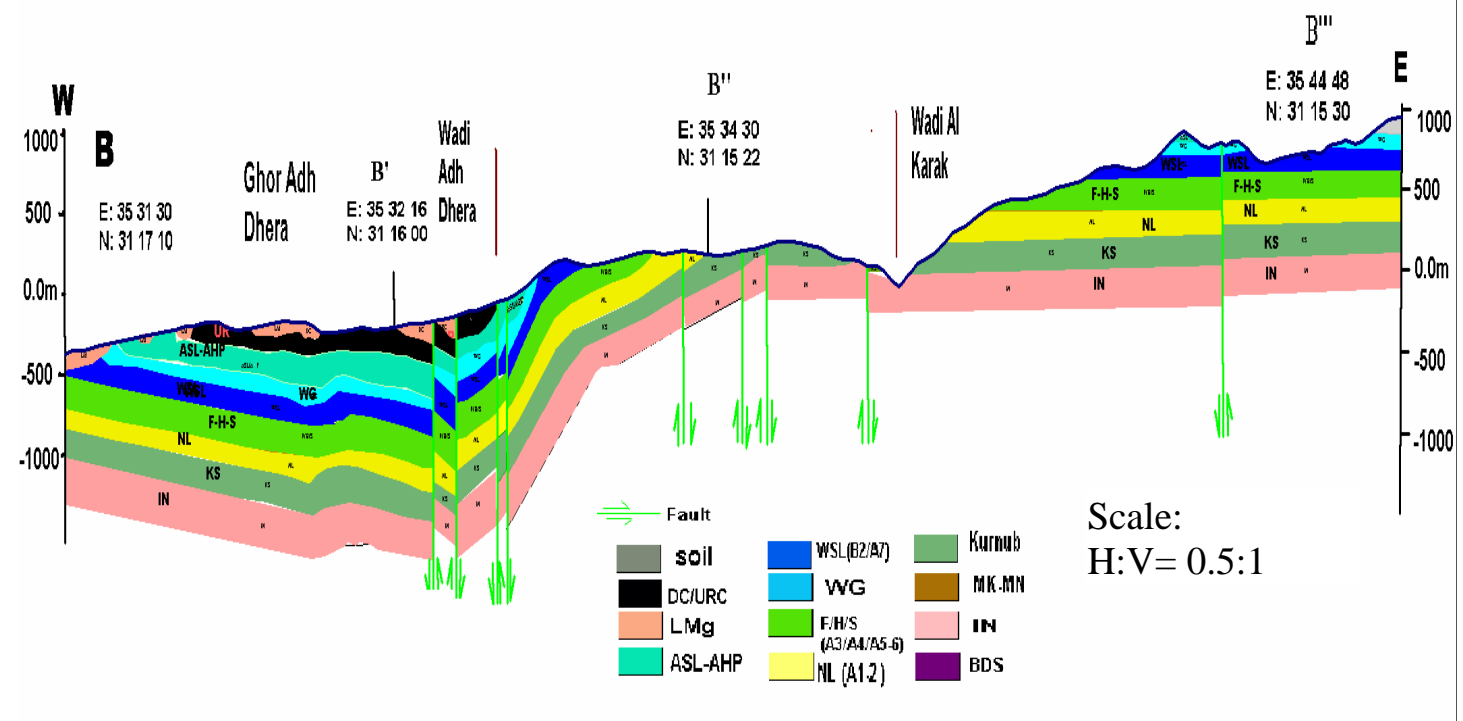

Figure (3-13): Geological cross section B-B'-B"-B'"' in Ghor Haditha.

The cross section B-B'- $\mathrm{B}^{\prime \prime}-\mathrm{B}^{\prime \prime \prime}$ is located in the southern of the study area at Gohr Haditha (Fig. 3-13) close to the southern basin of the Dead Sea. The direction of this section is W-E. The section shows that the layers in the eastern part are quite horizontal and the topography is high. The topography slopes toward the west direction and the layers dip sharply to the west and then become horizontal with very small dip angle. The deep aquifers Umm Ishrin sandstone (IN) and Kurnub sandstone (KS) are outcropping in Wadi Al Karak. As well the upper aquifer crops out at east of Wadi Al karak and at Wadi Adh Dhera. The surface water and groundwater are expected to flow toward the Wadi Al Karak from the eastern mountains. The groundwater might be flowing from the east toward Wadi Adh Dhera. 

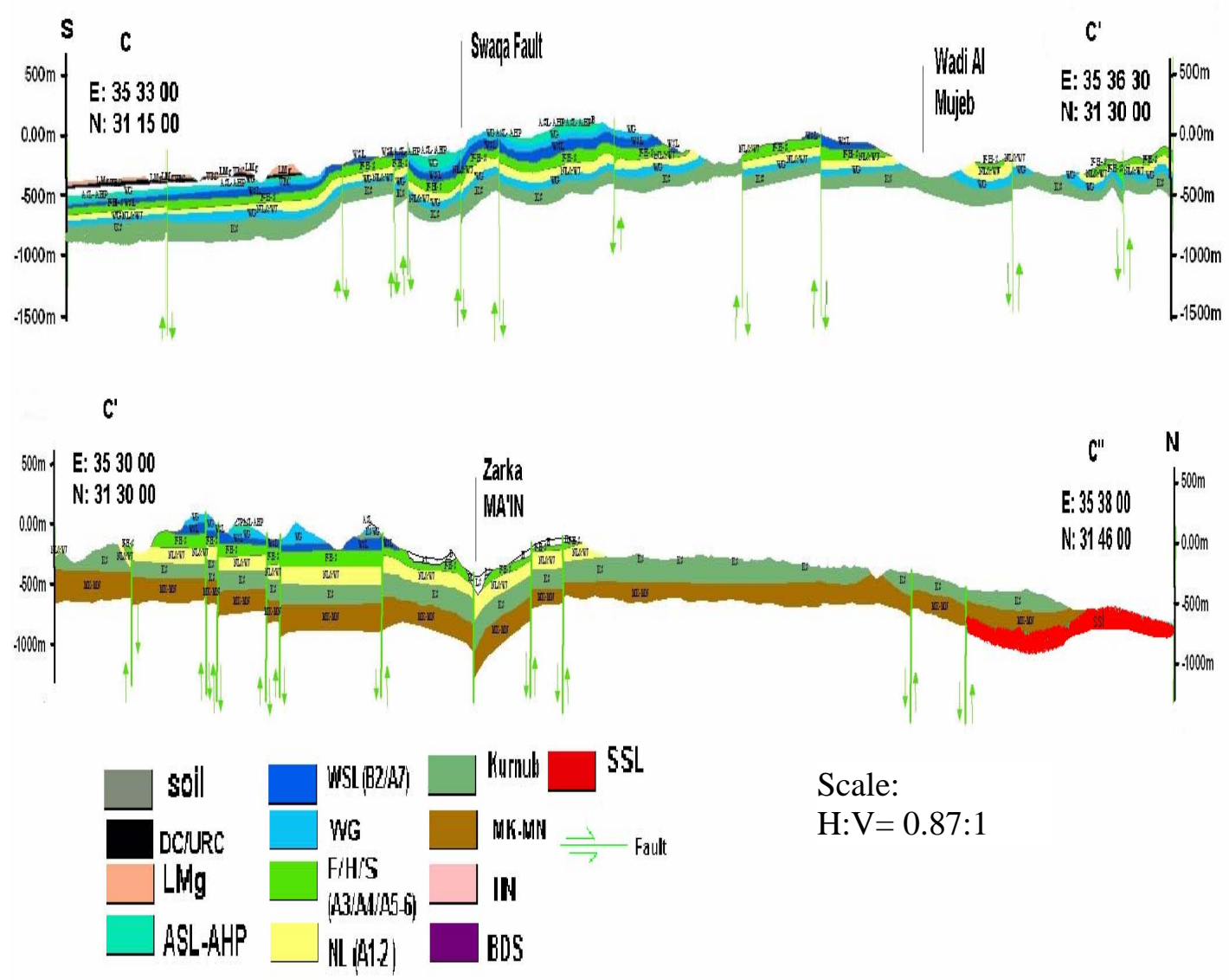

Figure (3-14): Geological cross section C-C`-C" parallel to the Dead Sea

One cross section (C-C'-C") was constructed parallel to the Dead Sea in a S - N direction. It extends from Ghor Hadetha, southern part of the Dead Sea, to Sweimah, northern part of the Dead Sea (Fig. 3-14). The figure shows that the Siwaqa fault intersects the section. South of Siwaqa fault, the layers dip to the south while in the north of Siwaqa fault the layers dip to the north (apparent dip). The lower aquifer (Kurnub sandstones) crops out at the northern part while they are overlying with the younger strata at the southern part. Considering the 3-D situation the groundwater is expected flows west with a southerly component of Siwaqa. As well considering the northerly components of Siwaqa the groundwater might be flowing to the north to Wadi Mujeb then it continues to the west toward the Dead Sea. The groundwater at the area located between Wadi Mujeb and Wadi Zarka Ma'in might be flowing toward Wadi Mujeb and Wadi Zarka Ma'in then it continues toward the Dead Sea at the west. Also, considering the northerly components north of Wadi Zarka Ma'in the groundwater might be flowing to the 
north direction parallel to the Dead Sea then it continues to the west toward the Dead Sea.

\subsection{Integration of Techniques}

The integration of techniques is one key to element a successful study. While each technique by itself can offer a partial view of the discharge, a suitable and correct integration between the methods provides proper focus about the research. In this section of the research the integration among the different methods, geological model and structural features, electrical conductivity $(E C)$ and temperature $(T)$ with the depth, chemical tracer (radon-222), thermal infrared imagery, electromagnetic radiation and water budget were applied to get a better view and results to locate and to estimate the submarine groundwater discharge into the eastern shores of the Dead Sea.

The geological and the topographical maps of scale 1:50,000 covering the study area were used to produce a geological model, and to determine the geological characteristics of the area. Using the results obtained from the geological model, the study area can be subdivided into three sub areas (stations) related to their different geological setup. Using the results obtained from the geological and topographic maps localized the expected locations of the groundwater discharge. These findings are combined with the finding of the electromagnetic radiation, which supported the findings resulting obtained from the geological interpretation and the geological model.

The data obtained from the methods, mentioned above, were used to determine the most suitable sites for electrical conductivity, temperature with the depth surveying measurements, which depend on the contrast between the saline Dead Sea water and the fresh groundwater which feed the Dead Sea along its shores. Accordingly four stations were chosen for measurements, depending on the geological findings and field survey. These measurements gave us an idea about the depths underneath the surface of the Dead Sea where the fresh groundwater dischrarge into the Dead Sea as submarine springs or seepages.

The findings obtained from EC and T with the depth measurements were used to determine the most suitable depths and distance to collect samples for Radon-222 measurements. The compenation between the electrical conductivity-Temperature technique and the chemical tracer technique gave us an idea about the layring of the Dead Sea water.

Thermal infrared imagery results were used to determine the length of the shore where the water discharges occur and its extending from the shoreline. These results were used to calculate the quantity of discharges using radon-222 method. 


\section{FIELDWORK}

\subsection{Electrical Conductivity-Temperature with Depth}

Different vertical profiles of the EC and T with depth measurements were taken at discrete stations by using small engine boat between July and August 2005 (summer months) after several drought winter seasons. The measurements were carried out at daytime between 11 a.m. and 16 p.m. That time was chosen because of the sea was calm or very low tide.

The first station $\left(\mathbf{S}_{\mathbf{1}}\right)$ was located at the northern part of the Dead Sea in Sweimah (Hotel area) at the coordinate $1129 \mathrm{~N}$ and 205.5 E PG (Palestine grid coordinate system).

Five vertical water column profiles were carried out at these stations. The first profile $\left(\mathbf{S}_{1-1}\right)$ was carried out at 200 meter away from the shoreline of the Dead Sea. The EC and T with depth measurements were carried out for a depth from 1 $\mathrm{m}$ to total $55 \mathrm{~m}$. Then the boat was moved farther to the west for about $300 \mathrm{~m}$ from the shoreline where, the second $\left(\mathbf{S}_{1-2}\right)$ vertical profile was located. The measurements were carried out from the depth $1 \mathrm{~m}$ to $45 \mathrm{~m}$ below Dead Sea surface then the measurements stopped due to the deviation in the sensor underneath this depth. The third $\left(\mathbf{S}_{1-3}\right)$ vertical profile at this station was located at a distance of $400 \mathrm{~m}$ from the shoreline to the west. The EC, T and depth measurements in this profile were carried out from $1 \mathrm{~m}$ to $94 \mathrm{~m}$ depth. The fourth $\left(\mathbf{S}_{1-4}\right)$ profile at this station was at distance of about $500 \mathrm{~m}$ from the shoreline. The measurements were carried out from a depth $1 \mathrm{~m}$ to $88 \mathrm{~m}$ below Dead Sea surface. The measurements at the fifth $\left(\mathbf{S}_{1-5}\right)$ vertical profile at the first station were carried out from $1 \mathrm{~m}$ to $93 \mathrm{~m}$ below Dead Sea level at the distance of $800 \mathrm{~m}$ away from the shoreline to the west.

The second station $\left(\mathbf{S}_{\mathbf{2}}\right)$ was located in Zarka Ma'in area at the middle part of the Dead Sea to the south of the first station. It was located at a coordinate of $1114 \mathrm{~N}$ $P G$ and 203 E PG.

The EC, T and depths were measured at this area at a different four vertical column profiles. These profiles also were located at a different distance away from the shoreline and at different depth from the Dead Sea water surface. The distance of the first vertical profile $\left(\mathbf{S}_{2-1}\right)$ was located at about $100 \mathrm{~m}$ away from the shoreline to the west direction. The measurements at this profile were carried from $1 \mathrm{~m}$ to 80 $\mathrm{m}$ depth. The measurements at the second profile $\left(\mathbf{S}_{2-2}\right)$, which was located about $200 \mathrm{~m}$ away from shoreline, were carried out from a depth $1 \mathrm{~m}$ to $91 \mathrm{~m}$ beneath the Dead Sea water surface. The third vertical profile $\left(\mathbf{S}_{2-3}\right)$ at the Zarka Ma'in area was located at about $400 \mathrm{~m}$ away from the shoreline to the west direction. The EC, $\mathrm{T}$ and depths measurements for this profile were carried out from a $1 \mathrm{~m}$ to $96 \mathrm{~m}$ 
depth. The farthest EC, T and depth profile at this station is profile 4 which donated as $\left(\mathbf{S}_{2-4}\right)$. It located at about $800 \mathrm{~m}$ away from the shoreline to the west direction. The measurements were carried from a depth $1 \mathrm{~m}$ to $94 \mathrm{~m}$ beneath the Dead Sea surface.

The third station $\left(\mathbf{S}_{\mathbf{3}}\right)$ was located in Zara area at the coordinate of $1111.8 \mathrm{~N} \mathrm{PG}$ and 202.8 E PG. This area includes many hot springs discharging to the Dead Sea. The temperatures of these springs range from about $40^{\circ} \mathrm{C}$ to about $60^{\circ} \mathrm{C}$ at the source.

Four different EC, T and depths vertical profiles were carried out at this area relating to the distance from the shoreline. The first profile $\left(\mathbf{S}_{3-1}\right)$ was carried out at $100 \mathrm{~m}$ distance from the shoreline to the west direction. The depth of this profile was from $1 \mathrm{~m}$ to $84 \mathrm{~m}$ beneath the Dead Sea water surface. The second profile $\left(\mathbf{S}_{3}\right.$ 2) was carried out about $300 \mathrm{~m}$ distance away from the shoreline to the west. The depth of this profile was from $1 \mathrm{~m}$ to $89 \mathrm{~m}$. The EC, T and depths for the third profile $\left(\mathbf{S}_{3-3}\right)$ were carried out from a depth $1 \mathrm{~m}$ to $96 \mathrm{~m}$. This profile located at about $400 \mathrm{~m}$ away from the shoreline to west direction. The last profile at this area $\left(\mathbf{S}_{3-4}\right)$ was located of about $800 \mathrm{~m}$ distance away from the shoreline and the measurements were carried out from a $1 \mathrm{~m}$ depth to $94 \mathrm{~m}$ beneath the Dead Sea water surface.

The last station $\left(\mathbf{S}_{\mathbf{4}}\right)$ at the investigated area was located in Mujeb area at the south part of the Dead Sea. This station was located at the coordinate of 1097.178 N PG and 203 E PG. The EC, T and depths vertical profile were carried out at this station for one vertical profile $\left(\mathbf{S}_{4-1}\right)$. This profile located at about $400 \mathrm{~m}$ distance away from the shoreline to the west direction. The depth of this profile was from $1 \mathrm{~m}$ to $87 \mathrm{~m}$ beneath the surface of the Dead Sea water. The location of the main stations are shown in (Fig. 4-14)

Representative samples from the Dead Sea water in Mujeb station were collected from different depths for chemical analysis. The samples were transferred to the laboratory for chemical analysis.

As well a small pump was used for sampling the Dead Sea water from different depths and deffernet stations. The samples were pumped directly from the specific depth into $250 \mathrm{ml}$ plastic bottles at the same time they contemporaneous of carrying out the measurements. All the samples ( $n=15$ samples) were transported to the laboratory for determining the total dissolved solids (TDS) of the Dead Sea water using a traditional technique (Gravimetric Technique). 


\subsection{Chemical Tracer (Radon-222)}

Radon-222 measurements were carried out on the same day of carrying out the EC, T and depth measurements between July and August 2005 using the same small engine boat and the small submersible water pump. Samples with a volume between 30 and $35 \mathrm{ml}$ were collected from different depths and different distances away from the shoreline as well as from different stations along the Eastern shoreline of the Dead Sea. Stations were located almost at the same locations of the electrical EC, T and depth stations with differences in the distances from the shoreline. These stations were spread from the north to the south along the Eastern shoreline of the Dead Sea.

Four main stations were chosen for ${ }^{222} \mathrm{Rn}$ sampling. The first station $\left(\mathrm{S}_{\mathrm{rn} 1}\right)$ was located in Sweimah area (Hotels area) of about $20 \mathrm{~m}$ distance away from the coastline. Five samples were collected from this station at five different depths. The first sample was from a depth $2 \mathrm{~m}$ underneath the Dead Sea water surface. Then the pump was taken down to a $4 \mathrm{~m}$ depth for sampling a next sample, and then it was taken down to a depth $7 \mathrm{~m}$ for sampling the third sample. The fourth sample was collected from a depth of $12 \mathrm{~m}$, and the last sample was collected from a depth of $20 \mathrm{~m}$ underneath DS surface by taking down the pump to that depth. These samples were used for calculating the ${ }^{222} \mathrm{Rn}$ inventory, radon-222 diffusion to the air, radon-222 in sediments and radon production from radium-226. As well some samples were collected to the west of this station at a distance of about $60 \mathrm{~m}$ away from the shoreline at depths of $12 \mathrm{~m}$ and $20 \mathrm{~m}$. Three samples at $12 \mathrm{~m}$ depth were collected at a distances of about $200 \mathrm{~m} 300 \mathrm{~m}$ and $700 \mathrm{~m}$ away from the shoreline to the west of the main station $\left(\mathrm{S}_{\mathrm{rn} 1}\right)$. Three samples were collected at 2 $\mathrm{m}$ depth at the north of the main station with $5 \mathrm{~km}$ and with distances $50 \mathrm{~m}, 200 \mathrm{~m}$ and $700 \mathrm{~m}$ away from the shoreline. One sample was collected at about $5.5 \mathrm{~km}$ to the north of the main station and distance about $200 \mathrm{~m}$ away from the shoreline.

The second main station $\left(\mathrm{S}_{\mathrm{rn} 2}\right)$ for the radon-222 sampling was located in Zarka Ma'in area. The distance of this station was between $20-30 \mathrm{~m}$ away from the shoreline to the west direction. The samples from this station were collected also from different depths using the same procedures, which were used in the first station and as the same way of sampling. The first sample was collected from $2 \mathrm{~m}$ depth. The second sample was collected from a depth $4 \mathrm{~m}$. The third, fourth and fifth samples were collected from depths 7,12 , and $24 \mathrm{~m}$ respectively using the same procedures and sampling techniques. These samples also were used for calculating the radon-222 inventory, diffusion from the sediment, and the radon222 evasion to the atmosphere surrounding the station. In order to testing the radon-222 distribution at this station many other samples were collected from different distances away from the main station. Two samples were collected from 4 $\mathrm{m}$ depth at distances $10 \mathrm{~m}$ and $40 \mathrm{~m}$ away from the shoreline to the west direction at the same location of the main station. Two samples were collected at $4 \mathrm{~m}$ depth at distances $10 \mathrm{~m}$ and $40 \mathrm{~m}$ away from the shoreline to the west direction at $300 \mathrm{~m}$ 
north of the main station. One sample was collected from a depth $4 \mathrm{~m}$ at distance about $10 \mathrm{~m}$ away from the shoreline at $800 \mathrm{~m}$ north of the main station.

As well radon-222 samples were collected from the third main station $\left(\mathrm{S}_{\mathrm{rn} 3}\right)$. This station was located in Zara (Hot springs) area. As in the other stations the radon222 samples were collected from different depth and different distances away from the shoreline to the west and different distances toward north or south from the main station. The samples from this main station were used later for calculating the radon-222 inventory, diffusion from the sediments and atmospheric evasion. The depths of the samples at this main station were $2 \mathrm{~m}, 4 \mathrm{~m}, 7 \mathrm{~m}, 12 \mathrm{~m}$, and $24 \mathrm{~m}$ underneath of the Dead Sea water surface and the distance of these samples nearly were 20 to $25 \mathrm{~m}$. One sample was collected at depth of $12 \mathrm{~m}$ and distance $50 \mathrm{~m}$ away from the shoreline to the west of the main station. Two samples were collected at a depth $12 \mathrm{~m}$ of about $20 \mathrm{~m}$ and $30 \mathrm{~m}$ distances away from the shoreline and about $150 \mathrm{~m}$ to the north of the main station. Two samples were collected from a depth $12 \mathrm{~m}$ at the distances $20 \mathrm{~m}$ and $50 \mathrm{~m}$ away from the shoreline at a distance of about $500 \mathrm{~m}$ north of the main station. Six samples were collected at about $500 \mathrm{~m}$ distance to the south of the main station, two samples were collected at $12 \mathrm{~m}$ depth and a distances $20 \mathrm{~m}$ and $40 \mathrm{~m}$ away from the shoreline, and four samples were collected from $4 \mathrm{~m}$ depth at distances $20 \mathrm{~m}, 30$ $\mathrm{m}, 40 \mathrm{~m}$ and $50 \mathrm{~m}$ away from the shoreline. As well three samples were collected from about $1000 \mathrm{~m}(1 \mathrm{Km})$ south of the main station at the depth of about $12 \mathrm{~m}$ and distances of about $20 \mathrm{~m}, 50 \mathrm{~m}$ and $200 \mathrm{~m}$ away from the shoreline to the west of the main station. One sample was collected at distance $3000 \mathrm{~m}(3 \mathrm{Km})$ to the south of the main station at a depth of $12 \mathrm{~m}$ and a distance of about $20 \mathrm{~m}$ away from the shoreline to the west.

The last main station for radon-222 sampling located in Mujeb area. This station was named $\left(\mathrm{S}_{\mathrm{rn} 4}\right)$. The radon-222 samples from this station were collected from the main station only because of the time of borrowing the boat was finished and could not extended. The samples were collected from this station at different depths. The first sample was collected from a depth $2 \mathrm{~m}$, the second one was collected form a depth $4 \mathrm{~m}$. The third, fourth and fifth samples were collected from depths of $7 \mathrm{~m}$, $12 \mathrm{~m}$, and $24 \mathrm{~m}$ respectively.

The number, the time of sampling, the depth, the station name, the distance from the shoreline and the distance from the main station and directions were written down in situ for each sample. The samples were transferred to the laboratory in order to analyze for radon-222 concentrations for each sample.

\subsection{Thermal Infrared Imagery (TIR)}

A thermal infrared survey was flown parallel over the study area at the eastern shoreline of the Dead Sea to circumscribe the groundwater discharge zones,. Four 
flight lines (strips) were taken between Zarka Main area and south Mujeb for an area approximately $75 \mathrm{~km}^{2}$ (Fig. 4-1).

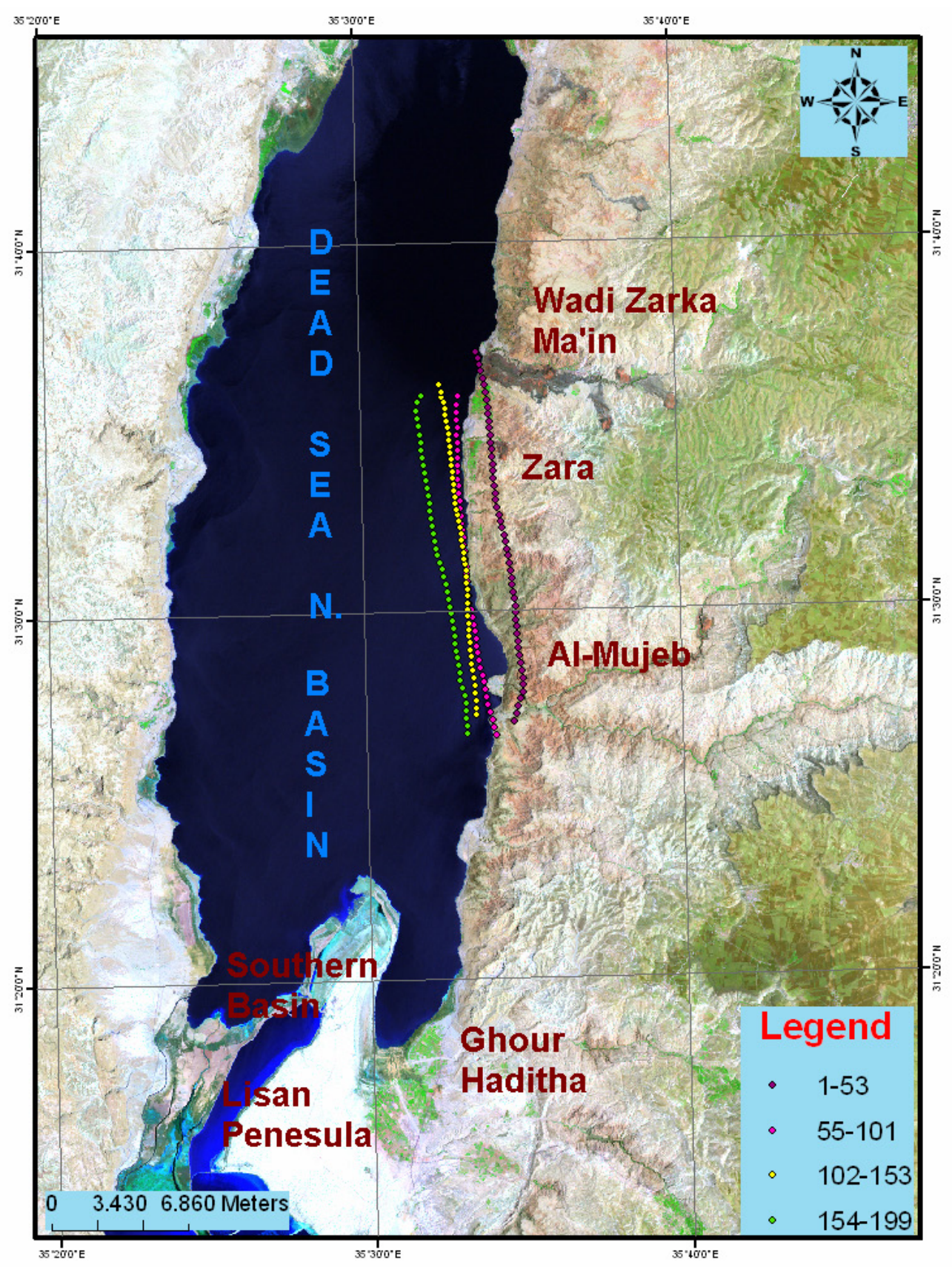

Figure (4-1): Thermal infrared flight strips over the Dead Sea

The thermal infrared imagery was performed using a thermal infrared camera that was fixed at the bottom of the small commercial plane. The survey was performing in December 2005 (winter season) and the time was between 19 and 20 P.M. This time and season were chosen to maximize temperature differentials between the 
groundwater and sea surface temperatures at the same time to take an advantage of the lack of shadows cover, which can shield an anomaly from the TIR. The survey was performed at 1300-1600 m elevations. The TIR survey consisted highresolution $(4-8 \mathrm{~m})$ imagery depending on the height of the plane. There was about $10-40 \%$ TIR image footprint overlap between adjacent flight lines and about 25$40 \%$ also footprint overlap between the images along the same flight line. Survey conditions were good for identifying discharge zones: clear sky, ambient air Temperature $20-21^{\circ} \mathrm{C}$, expected groundwater temperatures of $35^{\circ} \mathrm{C}$ in Zarka Ma'in, Zara and south Zara areas which have a hot springs, which expected about $26^{\circ} \mathrm{C}$ in Mujeb and adjacent areas. The coordinates of the images were obtained from a stationary GBS stations. One of these stations was fixed inside the plane top of the thermal camera, and the second GBS station was fixed on the ground at the airport. The coordinates were taken continuously from the starting point at the airport to the end point back to the airport.

\subsection{Electromagnetic Radiation (EMR)}

Four electromagnetic radiation profiles were carried out along the eastern coast of the Dead Sea. At the beginning the instrument was calibrated related to the number of beaks, amplification and frequency.

The first profile was carried out in Sweimah area. The beginning of the profile was at the coordinate $31^{\circ} 43^{\prime} 62.7^{\prime \prime} \mathrm{N}$ and $35^{\circ} 35^{\prime} 33.4^{\prime \prime} \mathrm{E}$, and the end of the profile was at the coordinate $31^{\circ} 45^{\prime} 45.07^{\prime \prime} \mathrm{N}$ and $35^{\circ} 34^{\prime} 33.48^{\prime \prime} \mathrm{E}$. The long of this profile was about $4 \mathrm{~km}$.

One profile with a length about $3 \mathrm{~km}$ was carried out at south Sweimah area. This profile denoted as second profile. The starting point of this profile was located at the coordinate $31^{\circ} 41^{\prime} 28.18^{\prime \prime} \mathrm{N}$ and $35^{\circ} 34^{\prime} 38.87^{\prime \prime} \mathrm{E}$, and the ending point was at the coordinate $31^{\circ} 43^{\prime} 19.6^{\prime \prime} \mathrm{N}$ and $35^{\circ} 35^{\prime} 08^{\prime \prime} \mathrm{E}$.

The third profile was carried out in Zara area. The beginning of the profile was at coordinate $31^{\circ} 34^{\prime} 43.83^{\prime \prime} \mathrm{N}$ and $35^{\circ} 33^{\prime} 9.92^{\prime \prime} \mathrm{E}$, and the end of the profile was at coordinate $31^{\circ} 36^{\prime} 31.66 \mathrm{~N}$ and $35^{\circ} 33^{\prime} 44.96^{\prime \prime} \mathrm{E}$. The long of this profile was about $2.8 \mathrm{~km}$.

The last profile was carried out in Mujeb area. This profile was numbered as profile four. It was located at the coordinate $31^{\circ} 26^{\prime} 57.48^{\prime \prime} \mathrm{N}$ and $35^{\circ} 33^{\prime} 55.74^{\prime \prime} \mathrm{E}$ at the starting point and at coordinate of $31^{\circ} 28^{\prime} 39.92^{\prime \prime} \mathrm{N}$ and $35^{\circ} 34^{\prime} 25.40^{\prime \prime} \mathrm{E}$ at the end of the profile. The long of this profile was about $3.7 \mathrm{~km}$. 


\section{RESULTS AND INTERPRETATION}

\subsection{Electrical Conductivity-Temperature with Depth}

\section{- Laboratory work results and discussion}

The laboratory experiments, which were used for calibrating the inductive electrical conductivity device and for testing the efficiency of this device for temperature compensation shows that the inductive device works properly for temperature compensation at $25^{\circ} \mathrm{C}$. The experiments show also that the relationship between temperature and conductivity is a quadratic $\left(R^{2}=0.998\right)$ (Fig. 5-1). These experiments show that the electrical conductivity increases with temperature increase at constant TDS, while with the increase of the TDS at the same time of the increasing temperature to $40^{\circ} \mathrm{C}$ and coolling it back to $25^{\circ} \mathrm{C}$ the $\mathrm{EC}$ decreased.

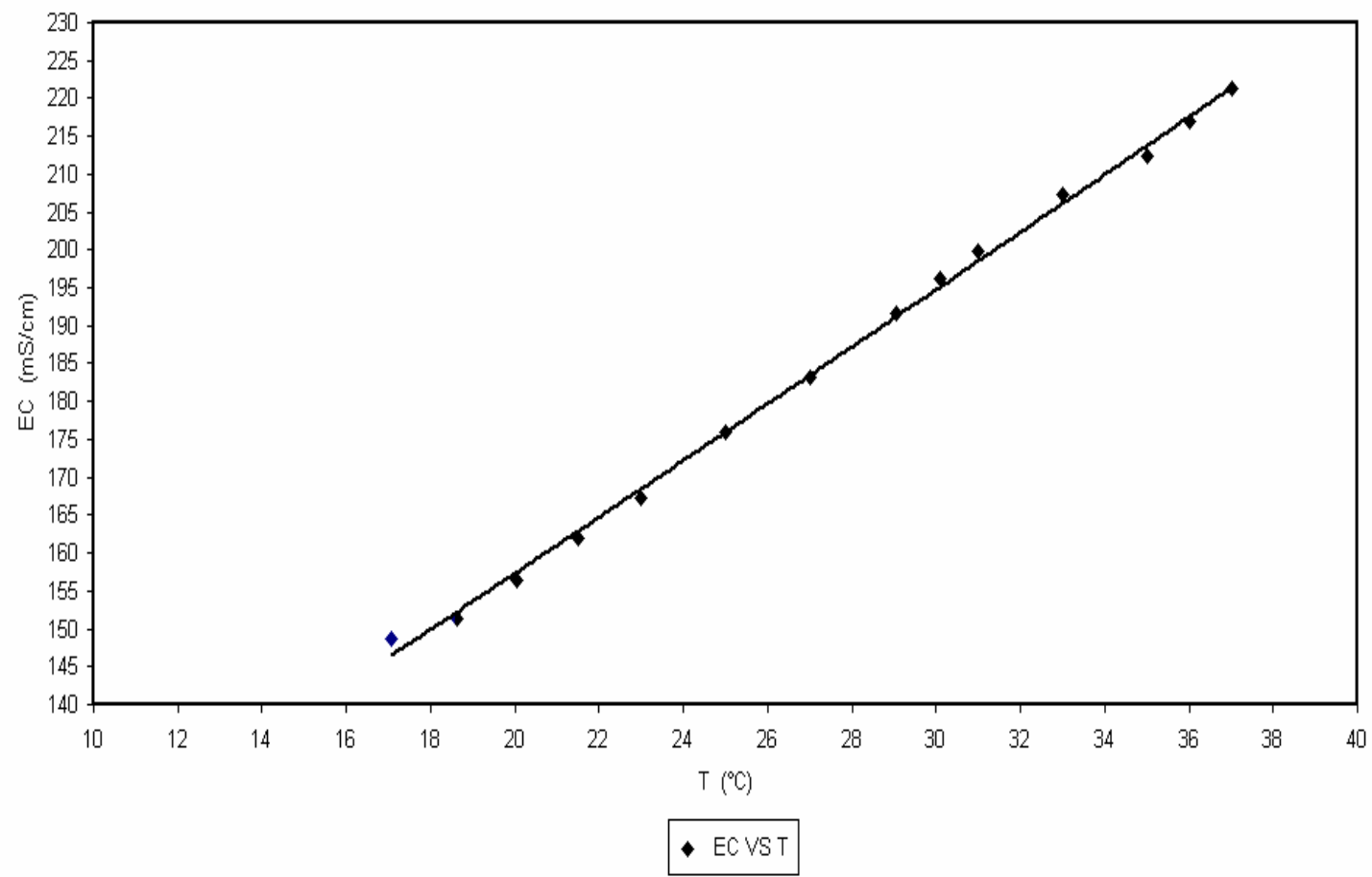

Figure (5-1): Relationship between EC and T for the inductive sensor.

Analyses of the representative samples from the Dead Sea water, which were collected in summer 2005, show that the TDS is $365 \mathrm{~g} / \mathrm{l}$. The concentration of $\mathrm{MgCl}_{2}$ is $52.2 \mathrm{~g} / \mathrm{l}$, the concentration of sodium cations is $32.47 \mathrm{~g} / \mathrm{l}$ and the chloride ions is $250 \mathrm{~g} / \mathrm{l}$. The concentrations of cations and anions of the Dead Sea water during summer 2005 are listed in table (5-1). 
Table (5-1): Dead Sea water composition during summer 2005 (in $\mathrm{g} / \mathrm{l}$ ).

\begin{tabular}{|lllllllll|}
\hline $\mathrm{Na}^{+}$ & $\mathrm{K}^{+}$ & $\mathrm{Ca}^{+2}$ & $\mathrm{Mg}^{+2}$ & $\mathrm{Cl}^{-}$ & $\mathrm{Br}^{-}$ & $\mathrm{HCO}^{-}$ & $\mathrm{SO}^{-2}$ & $\mathrm{TDS}$ \\
\hline 32.47 & 7.8 & 17.1 & 52.2 & 250 & 5.4 & 0.3 & 0.4 & 365.67 \\
\hline
\end{tabular}

The realationship between the EC and the TDS was established in the laboratory. Laboratory experiments were carried out for calibrating the EC inductive device and for understanding the behaviour of the EC and the TDS for very high saline water as it as of the Dead Sea water. These experiments were done on standard salts. The salts were mixed with a distilled water to get 6 litters of solution with salinity of $380 \mathrm{~g} / \mathrm{l}$. This mixture was diluted gradually with $25 \mathrm{ml}$ of distilled water for about one hundred and thirty times $\left(R^{2}=0.9994\right)$. After that the relationship between the EC and the salinity was obtained as a quadratic relationship (Fig. 5-2). The right side of this quadratic curve was used later on for the interpretation of the field data results.

This quadratic curve (Fig. 5-2) shows that the relationship between the electrical conductivity and the salinity is indirect relationship for very high saline water (i.e. the electrical conductivity at a certain point of salt concentration begins to decrease with the increasing of salinity). The curve shows also that the maximum value of the electrical conductivity is reached about $202 \mathrm{mS} / \mathrm{cm}$ at a TDS of about $267 \mathrm{~g} / \mathrm{l}$. Then this value starts to decrease with the increasing of salinity and it reached about $176 \mathrm{mS} / \mathrm{cm}$ at a salinity of about $404 \mathrm{~g} / \mathrm{l}$. The electrical conductivity might also reach to $157 \mathrm{mS} / \mathrm{cm}$ at salinity about $460 \mathrm{~g} / \mathrm{l}$. This curve was used latter to calculate the TDS and to interpret the field data results. 
Relationship EC VS TDS

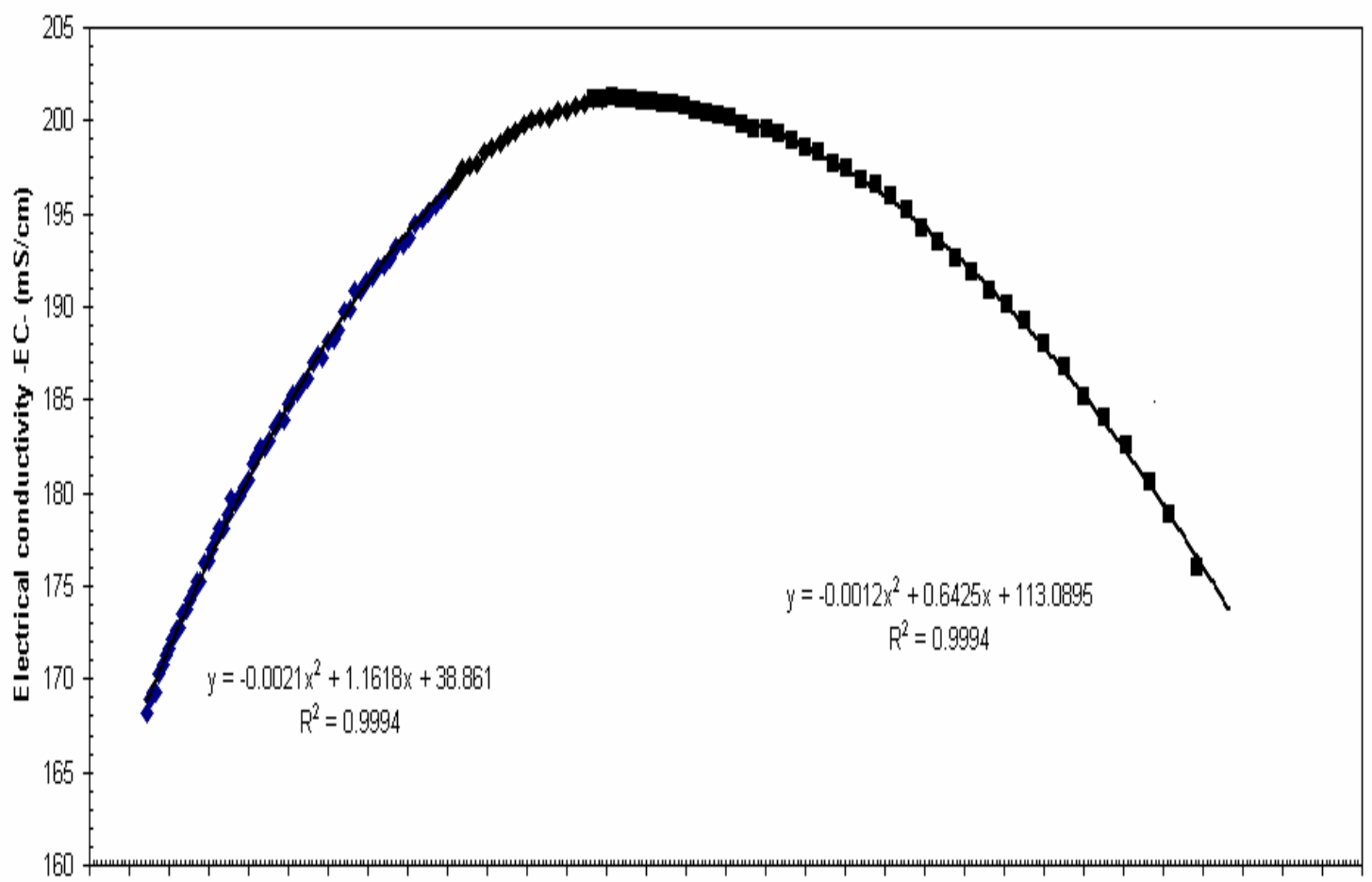

140150160170180190200210220230240250260270280290300310320330340350360370380390400410420430440450460

Total dissolved soloids-TDS- $(g /)$

Figure (5-2): Relationship between TDS and EC

TDS measured in the laboratory by using the Gravimetric technique shows that the maximum TDS was $464 \mathrm{~g} / \mathrm{l}$ in Mujeb area at a depth of $12 \mathrm{~m}$, and in Zarka Main at a depth of $4 \mathrm{~m}$ at distance $100 \mathrm{~m}$ from the shoreline. The minimum TDS value was $356 \mathrm{~g} / \mathrm{l}$ in Mujeb area at a depth of $15 \mathrm{~m}$ and in south Zara area at a depth of $4 \mathrm{~m}$. The TDS was also calculated for the same samples by using the following equation:

$Y=-0.0012 x^{2}+0.6425 x+113.0895$

That was obtained from the EC versus TDS curve (Fig. 5-2), where y is the EC and $x$ is the TDS. All the measured and calculated values of TDS are listed in table (42). 
Table (5-2): Measured and calculated TDS at different depths

\begin{tabular}{|c|c|c|c|}
\hline Area name & Depth (m) & $\begin{array}{l}\text { TDS }(\mathrm{g} / \mathrm{l}) \\
\text { measured }\end{array}$ & $\begin{array}{l}\text { TDS (g/l) } \\
\text { calculated }\end{array}$ \\
\hline \multirow{4}{*}{ 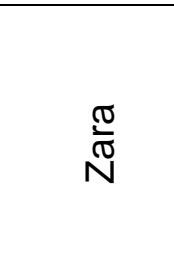 } & 4 & 370 & 354 \\
\hline & 7 & 372 & 362 \\
\hline & 15 & 412 & 409 \\
\hline & 24 & 410 & 412 \\
\hline \multirow{5}{*}{ 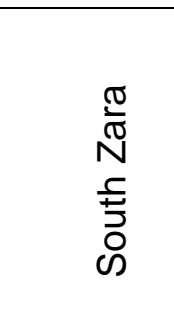 } & 2 & 362 & 387 \\
\hline & 4 & 356 & 379 \\
\hline & 7 & 386 & 367 \\
\hline & 15 & 396 & 363 \\
\hline & 24 & 444 & 418 \\
\hline \multirow{4}{*}{ 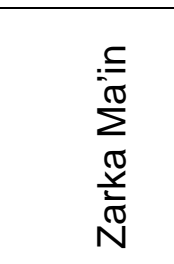 } & 4 & 391 & 390 \\
\hline & 4 & 416 & 425 \\
\hline & 4 & 464 & 450 \\
\hline & 4 & 440 & 438 \\
\hline \multirow{6}{*}{$\frac{.0}{\frac{0}{3}}$} & 2 & 412 & 408 \\
\hline & 4 & 398 & 401 \\
\hline & 7 & 388 & 390 \\
\hline & 12 & 464 & 451 \\
\hline & 15 & 356 & 355 \\
\hline & 24 & 440 & 422 \\
\hline
\end{tabular}

The maximum calculated value of TDS was $451 \mathrm{~g} / \mathrm{in}$ Mujeb area at a depth of 12 $\mathrm{m}$ and $450 \mathrm{~g} / \mathrm{l}$ in Zarka Ma'in area at a depth of $4 \mathrm{~m}$. The minimum TDS values were 355 and 354 in Mujeb at a depth of $15 \mathrm{~m}$ and in Zara at a depth of $4 \mathrm{~m}$ respectively. The differences between the measured TDS and the calculated TDS were $\pm 1-5 \%$. These differences may be presented because of some samples were not evaporated completely or are due to experimental errors. Generally, the measured and calculated TDS values are comparable with a significant corellations, which means that the curve and the equations used for calculating the TDS, are correct. The comparison between measured and calculated TDS values is shown in (Fig. 5-3). 
Comparative TDS.EVAP. and TDS.Calc.

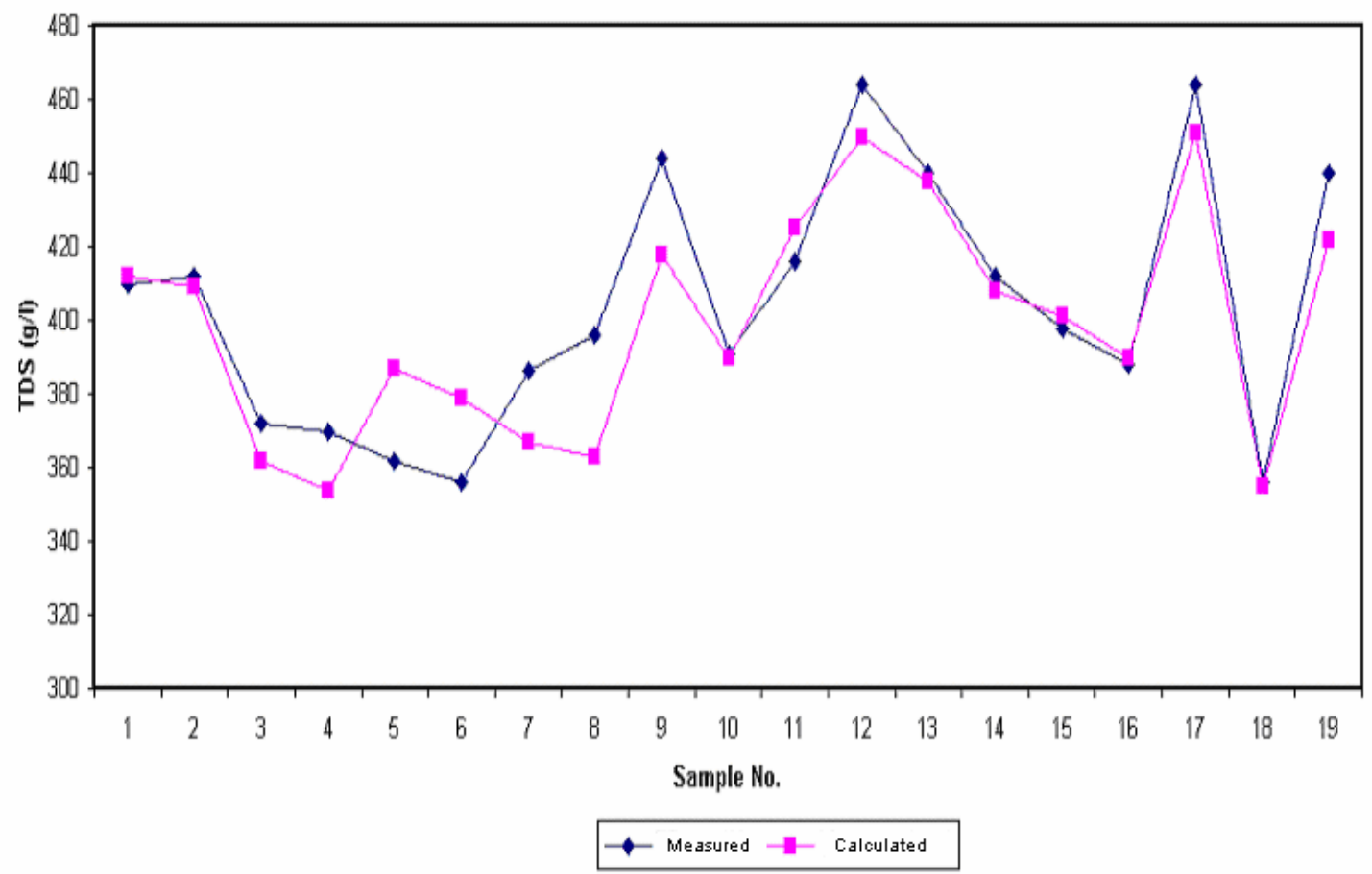

Figure (5-3): Comparison between measured and calculated TDS

Also the relationship between the EC and the TDS obtained in (Fig. 5-2) was approved by the laboratory's experiments by increasing the salinity gradually and measure the electrical conductivity after each salt adding. The salinity increases by adding known amounts of three different standard salts separately into the initial prepared standard solution $(380 \mathrm{~g} / \mathrm{l})$ into separate beakers.

The expermants show that the EC decreases by adding different known amounts of $\mathrm{MgCl}_{2}$ to the first beaker, which contained one litter of the initial standard solution. After adding $10 \mathrm{~g}$ of $\mathrm{MgCl}_{2}$ to that solution the $\mathrm{EC}$ decreased from 181.03 $\mathrm{mS} / \mathrm{cm}$ to $159.76 \mathrm{mS} / \mathrm{cm}$. After adding $5 \mathrm{~g}$ more of this salt the EC decreased to $148.58 \mathrm{mS} / \mathrm{cm}$. Adding $5 \mathrm{~g}$ more the EC decreased to $147.95 \mathrm{mS} / \mathrm{cm}$ and decreased to $146.47 \mathrm{mS} / \mathrm{cm}$ after adding the last $5 \mathrm{~g}$ of $\mathrm{MgCl}_{2}$.

The same behaviour was observed after adding different known amounts of $\mathrm{CaCl}_{2} \cdot 2 \mathrm{H}_{2} \mathrm{O}$. The EC decreases from $181 \mathrm{mS} / \mathrm{cm}$ to about $169.88 \mathrm{mS} / \mathrm{cm}$ after adding the first $10 \mathrm{~g}$ of $\mathrm{CaCl}_{2} \cdot 2 \mathrm{H}_{2} \mathrm{O}$. After adding the second $10 \mathrm{~g}$ the $\mathrm{EC}$ decreased to $164.59 \mathrm{mS} / \mathrm{cm}$. Then the EC continued decreasing by adding more and more of $\mathrm{CaCl}_{2} .2 \mathrm{H}_{2} \mathrm{O}$ until it reached an $\mathrm{EC}$ value of $148.89 \mathrm{mS} / \mathrm{cm}$ after the total adding become $60 \mathrm{~g}$. 
It was observed that the total amount of $\mathrm{CaCl}_{2} \cdot 2 \mathrm{H}_{2} \mathrm{O}$ dissolved completely when the solution was heated to $40^{\circ} \mathrm{C}$ and then a little amount of the salt started to precipitated when the solution was cooling down again to $25^{\circ} \mathrm{C}$.

The same behaviour was observed relating to the $\mathrm{EC}$ after adding $\mathrm{NaCl}$ salt to the solution. By adding the first $10 \mathrm{~g}$ of $\mathrm{NaCl}$ the $\mathrm{EC}$ decreased from $181 \mathrm{mS} / \mathrm{cm}$ to $166.89 \mathrm{mS} / \mathrm{cm}$. After adding the second $5 \mathrm{~g}$ the EC decreased to $159.55 \mathrm{mS} / \mathrm{cm}$. Then after adding the last $5 \mathrm{~g}$ of $\mathrm{NaCl}$ when the total added amount reached to 20 $\mathrm{g}$ the EC decreased to $152.4 \mathrm{mS} / \mathrm{cm}$. It was observed that $\mathrm{NaCl}$ dissolved completely at $40^{\circ} \mathrm{C}$. After adding $15 \mathrm{~g}$ of salt the solution starts to precipitate when cooling down to $25^{\circ} \mathrm{C}$. But after adding $20 \mathrm{~g}$ the salt did not dissolve completely in spite of heating to $40^{\circ} \mathrm{C}$. The results of the adding salt amounts and the $\mathrm{EC}$ results with the $\mathrm{T}$ are listed in the table (5-3).

Table (5-3): The effect of the salt adding on the EC

\begin{tabular}{|c|c|c|c|}
\hline Salt & $\begin{array}{l}\text { Amount } \\
\text { (g) }\end{array}$ & $\begin{array}{l}\text { Electrical } \\
\text { conductivity } \\
(\mathrm{mS} / \mathrm{cm})\end{array}$ & $\begin{array}{l}\text { Temperature } \\
\left({ }^{\circ} \mathrm{C}\right)\end{array}$ \\
\hline \multirow{5}{*}{$\begin{array}{l}\bar{N} \\
\frac{D}{2}\end{array}$} & 0 & 181.03 & 25 \\
\hline & 10 & 159.76 & 25 \\
\hline & 15 & 148.58 & 25 \\
\hline & 20 & 147.95 & 25 \\
\hline & 25 & 146.47 & 25 \\
\hline \multirow{7}{*}{ 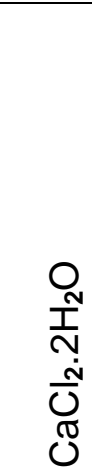 } & 0 & 181 & 25 \\
\hline & 10 & 169.88 & 25 \\
\hline & 20 & 164.59 & 25 \\
\hline & 30 & 158.6 & 25 \\
\hline & 40 & 157.0 & 25 \\
\hline & 50 & 152.44 & 25 \\
\hline & 60 & 148.89 & 25 \\
\hline \multirow{4}{*}{$\begin{array}{l}\bar{O} \\
\mathcal{Z}\end{array}$} & 0 & 180.8 & 25 \\
\hline & 10 & 166.89 & 25 \\
\hline & 15 & 159.55 & 25 \\
\hline & 20 & 152.4 & 25 \\
\hline
\end{tabular}


By comparing the results of the added salts it was found that after adding $10 \mathrm{~g}$ of $\mathrm{MgCl} 2,10 \mathrm{~g}$ of $\mathrm{CaCl}_{2} \cdot 2 \mathrm{H}_{2} \mathrm{O}$ and $10 \mathrm{~g}$ of $\mathrm{NaCl}$ the $\mathrm{EC}$ decreased by about 21 $\mathrm{mS} / \mathrm{cm}$, about $12 \mathrm{mS} / \mathrm{cm}$ and about $14 \mathrm{mS} / \mathrm{cm}$ respectively. The results show that the highest salt effect on the $\mathrm{EC}$ is from $\mathrm{MgCl} 2$ then from $\mathrm{NaCl}$ and the lowest is from $\mathrm{CaCl}_{2} \cdot 2 \mathrm{H}_{2} \mathrm{O}$. On the other hand the results showed that the $\mathrm{CaCl}_{2} \cdot 2 \mathrm{H}_{2} \mathrm{O}$ has higher solubility than the other two salts.

Density was measured for the three solutions after the last adding and for the initial salt solution $(380 \mathrm{~g} / \mathrm{l})$. The average density $(\mathrm{n}=5)$ for the initial solution (TDS 380 $\mathrm{g} / \mathrm{l})$ is $1.2472 \mathrm{~g} / \mathrm{cm}^{3}$. The average density $(\mathrm{n}=5)$ for the solution in the first beaker after adding $25 \mathrm{~g}$ of $\mathrm{MgCl}$ (TDS $405 \mathrm{~g} / \mathrm{l}$ ) is $1.25636 \mathrm{~g} / \mathrm{cm}^{3}$. The average density $(n=5)$ for the solution in the second beaker after adding $60 \mathrm{~g}$ of $\mathrm{CaCl}_{2} \cdot 2 \mathrm{H}_{2} \mathrm{O}$ is $1.275 \mathrm{~g} / \mathrm{cm}^{3}$ and the average density $(\mathrm{n}=5)$ for the solution in the third beaker after adding $20 \mathrm{~g}$ of $\mathrm{NaCl}$ was $1.26383 \mathrm{~g} / \mathrm{cm}^{3}$. These results are used to interpret the field results (latter on). The results were summarized in table (5-4)

Table (5-4): Densities at different TDS values after adding different amounts of salts.

\begin{tabular}{|c|c|c|c|}
\hline Type of Salt & $\begin{array}{l}\text { Adding amount } \\
(\mathrm{g} / \mathrm{l})\end{array}$ & $\begin{array}{l}\text { Final TDS } \\
(\mathrm{g} / \mathrm{l})\end{array}$ & $\begin{array}{l}\text { Density } \\
\left(\mathrm{g} / \mathrm{cm}^{3}\right)\end{array}$ \\
\hline Initial solution & & 380 & 1.2472 \\
\hline $\mathrm{MgCl}_{2}$ & 25 & 405 & 1.25636 \\
\hline $\mathrm{CaCl}_{2} \cdot 2 \mathrm{H}_{2} \mathrm{O}$ & 60 & 440 & 1.275 \\
\hline $\mathrm{NaCl}$ & 20 & 400 & 1.26383 \\
\hline
\end{tabular}

\section{- Combine the field and the laboratory results}

The results of EC and T with the depth profiles, which depend on the stations number, the distances away from the shoreline and the depths, are explaining as follows:

The Dead Sea water EC, depth, T and TDS results of all profiles of the first station, in Sweimah area at the northeastern corner of the Dead Sea, were plotted in (Figs 5-4 A, B, C, D and E). The TDS of all profiles were calculated using the formula obtained from the EC versus TDS curve (Fig. 4-2).

$Y=-0.0012 x^{2}+0.6425 x+113.0895$ 
The T, EC and TDS for the first profile $\left(S_{1-1}\right)$ at $200 \mathrm{~m}$ distance away from the shoreline (Fig. 5-4 A) show that:

The $\mathrm{T}$ at the surface of the Dead Sea water was $33.5^{\circ} \mathrm{C}$, it increased gradually with the increase the water depth down to $10 \mathrm{~m}$, and it reached $33.9^{\circ} \mathrm{C}$. Then it started decreasing from a depth of $11 \mathrm{~m}$ gradually until it reached $30.44^{\circ} \mathrm{C}$ at a depth of 18 $\mathrm{m}$. After that it decreased sharply at a depth of $19 \mathrm{~m}$ beneath the sea surface and it reached $29.77^{\circ} \mathrm{C}$. From this depth it decreased gradually until a depth of $27 \mathrm{~m}$ and it reached $28.18^{\circ} \mathrm{C}$ and it increased to $28.21^{\circ} \mathrm{C}$ at a depth of $29 \mathrm{~m}$. Finally it decreased gradually and it reached $25.59^{\circ} \mathrm{C}$ at a depth of $55 \mathrm{~m}$.

The TDS in this profile was $348 \mathrm{~g} / \mathrm{l}$ at the surface water. It increased gradually with the increase in the depth and it reached about $430 \mathrm{~g} / \mathrm{l}$ at a depth of $10 \mathrm{~m}$. After that it started decreasing and it reached about $413 \mathrm{~g} / \mathrm{l}$ at a depth of $17 \mathrm{~m}$ and increased locally at a depth of $18 \mathrm{~m}$ and it reached $416 \mathrm{~g} / \mathrm{l}$. Then it decreased gradually and it reached about $411 \mathrm{~g} / \mathrm{l}$ at a depth of $24 \mathrm{~m}$. After this depth it started increasing again gradually and it reached about $435 \mathrm{~g} / \mathrm{l}$ at a depth of $28 \mathrm{~m}$. Then it decreased gradually to a depth of $55 \mathrm{~m}$ and it reached about $413 \mathrm{~g} / \mathrm{l}$.

The EC results for this profile showed that the EC at the surface of the seawater was about $190.35 \mathrm{mS} / \mathrm{cm}$. It decreased gradually with the increasing in the depth and it reached about $166.11 \mathrm{mS} / \mathrm{cm}$ at a depth of $10 \mathrm{~m}$ underneath the sea surface. Then it started increasing and it reached about $172.44 \mathrm{mS} / \mathrm{cm}$ at a depth of $17 \mathrm{~m}$. At a depth of $18 \mathrm{~m}$ it decreased locally and it reached about $171.5 \mathrm{mS} / \mathrm{cm}$. After this depth it increased to about $173.34 \mathrm{mS} / \mathrm{cm}$ at a depth of $24 \mathrm{~m}$. From this depth it decreased again gradually until a depth of $28 \mathrm{~m}$ and it reached about $164.38 \mathrm{mS} / \mathrm{cm}$. Finally it increased again gradually until a depth of $55 \mathrm{~m}$ and it reached about $172.75 \mathrm{mS} / \mathrm{cm}$. 
TDS VS EC, Tem and Depth 200m from coast (Sweimah)

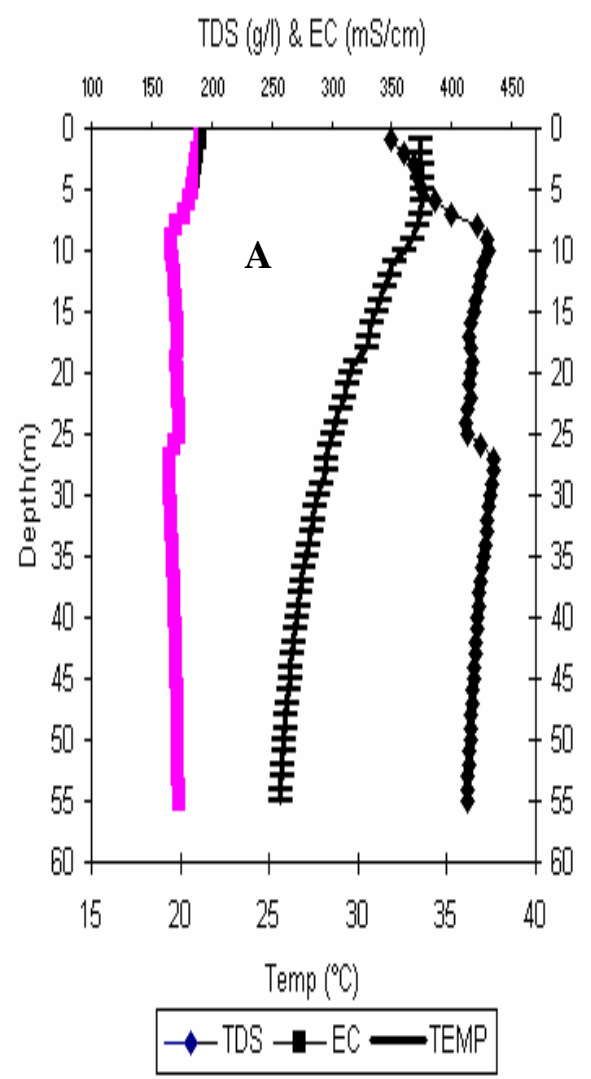

TDSVSEC, Tem and Depth 300m from coast (sweimah)

$\operatorname{TDS}(\mathrm{gll}) \& \mathrm{EC}(\mathrm{mS} / \mathrm{cm})$

$100 \quad 150 \quad 200 \quad 250 \quad 300 \quad 350 \quad 400 \quad 450$

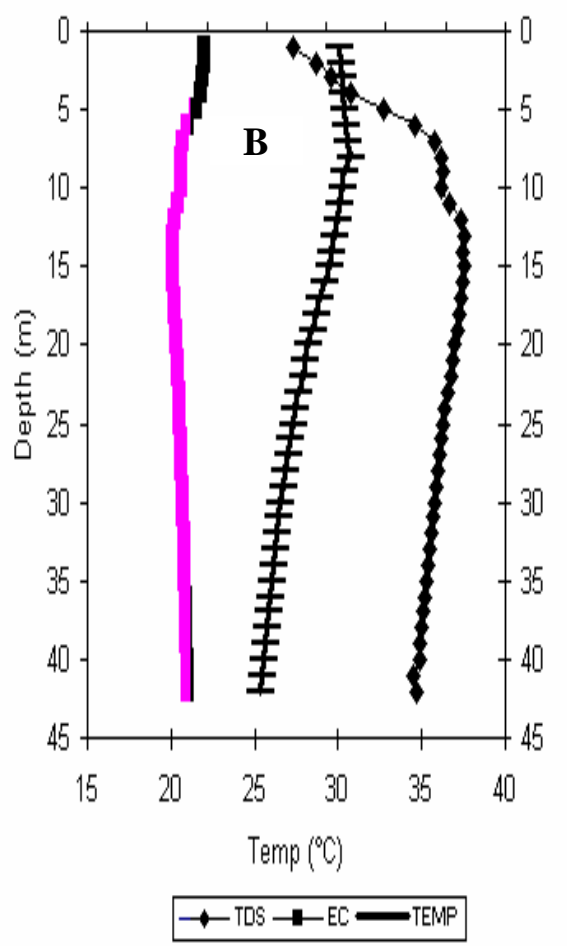

Figure (5-4A): EC, TDS and T Relationship with a depth in Sweimah area a distance of $200 \mathrm{~m}$ from the shoreline. Figure (5-4B): EC, TDS and T relationship with a depth in Sweimah area at a distance of $300 \mathrm{~m}$ from the shoreline.

The second profile at this station $\left(\mathrm{S}_{1-2}\right)$ at $300 \mathrm{~m}$ distance away from the shoreline (Fig. 5-4 B) showed that:

The $\mathrm{T}$ was $30.1^{\circ} \mathrm{C}$ at the seawater surface. It increased gradually and it reached $30.7^{\circ} \mathrm{C}$ at a depth of $9 \mathrm{~m}$ underneath the Dead Sea surface. Then it started decreasing gradually and it reached about $25.23^{\circ} \mathrm{C}$ at a depth of $43 \mathrm{~m}$.

The TDS measurements in this profile showed that the TDS at the surface water was about $272 \mathrm{~g} / \mathrm{l}$. After this depth it increased sharply and it reached about $397 \mathrm{~g} / \mathrm{l}$ at a depth of $9 \mathrm{~m}$. Then it gradually increased down at a depth of $15 \mathrm{~m}$ and it reached about $415 \mathrm{~g} / \mathrm{l}$. It started decreasing gradually to about $375 \mathrm{~g} / \mathrm{l}$ at a depth of $42 \mathrm{~m}$.

The EC results for this profile showed that the EC at the surface water was 198.4 $\mathrm{mS} / \mathrm{cm}$. This value decreased gradually and it reached its minimum value of this profile of $171.7 \mathrm{mS} / \mathrm{cm}$ at a depth of $15 \mathrm{~m}$ below the sea surface. Then it started increasing slowly and it reached $184.29 \mathrm{mS} / \mathrm{cm}$ at a depth of $42 \mathrm{~m}$. 

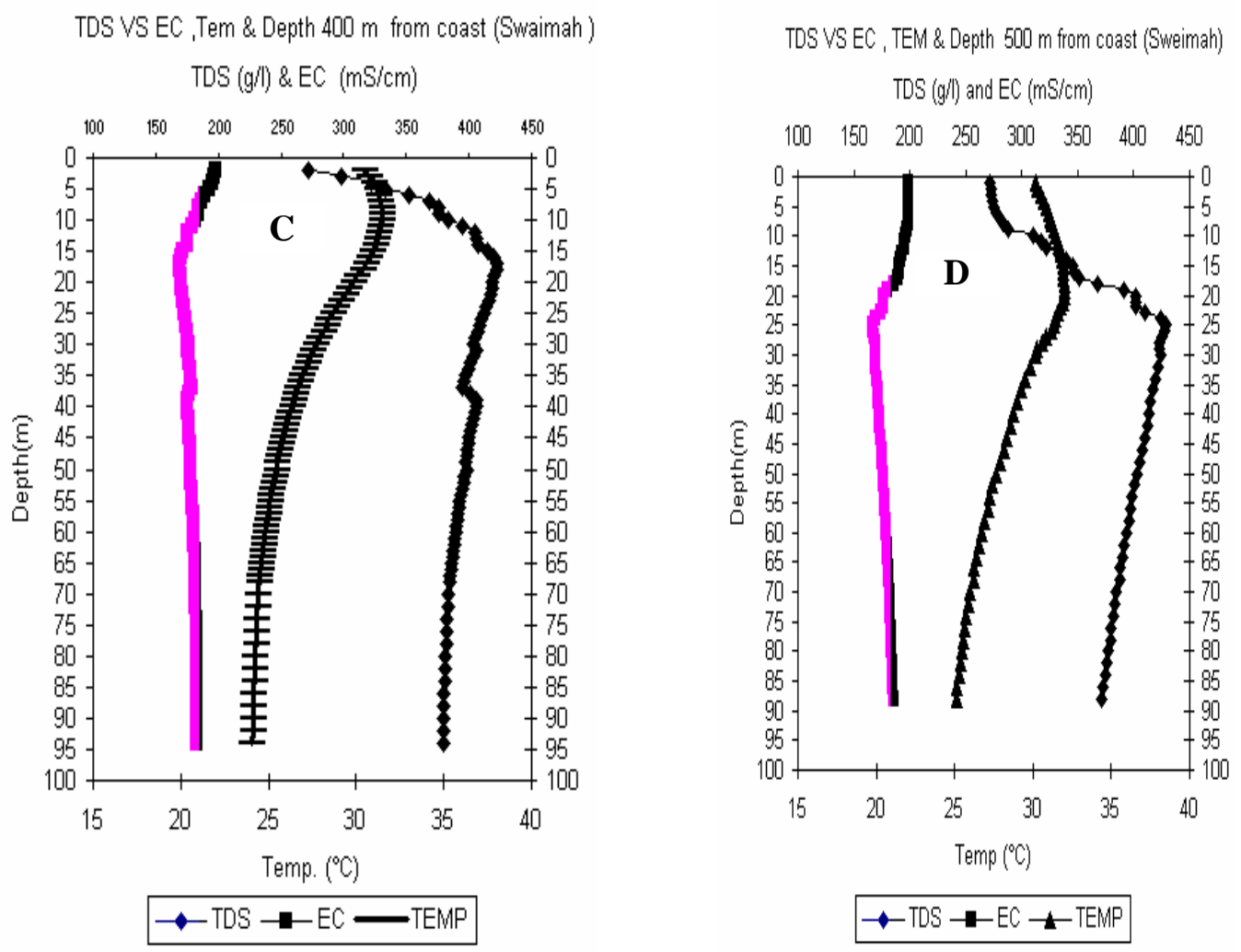

Figure (5-4C): EC, TDS and T Relationship with a depth in Sweimah area a distance of $400 \mathrm{~m}$ from the shoreline. Figure (5-4D): EC, TDS and T relationship with a depth in Sweimah area at a distance of $500 \mathrm{~m}$ from the shoreline.

The third profile $\left(\mathrm{S}_{1-3}\right)$ in the station 1 in Sweimah area at a distance of $400 \mathrm{~m}$ away from the shoreline (Fig. 5-4 C) displayed that the $\mathrm{T}$ at the surface was $30.54^{\circ} \mathrm{C}$. This value of $T$ started increasing slowly with the increase in the depth and it reached its maximum value $31.48^{\circ} \mathrm{C}$ at a depth of $10 \mathrm{~m}$. then it decreased slowly until it reached about $24.07^{\circ} \mathrm{C}$ at a depth of $94 \mathrm{~m}$ below the Dead Sea surface.

The lowest TDS value of this profile was $271.94 \mathrm{~g} / \mathrm{l}$ it was observed at the Dead Sea surface water. It started increasing until it reached its maximum value $422 \mathrm{~g} / \mathrm{l}$ at a depth of $17 \mathrm{~m}$. Then it reached about $394 \mathrm{~g} / \mathrm{l}$ at a depth of $37 \mathrm{~m}$ underneath the seawater surface. Then it increased again for few meters to reach $405 \mathrm{~g} / \mathrm{l}$ at a depth of $40 \mathrm{~m}$. After this depth it started decreasing gradually down to $94 \mathrm{~m}$ and it reached $379 \mathrm{~g} / \mathrm{l}$.

The illustrating of the EC results of this profile $\left(\mathrm{S}_{1-3}\right)$ showed that the EC was 198.4 $\mathrm{mS} / \mathrm{cm}$ at the surface seawater and it started decreasing with the increase in the depth and it reached its minimum value $169.5 \mathrm{mS} / \mathrm{cm}$ at a depth of $17 \mathrm{~m}$. It started increasing gradually and it reached $176.64 \mathrm{mS} / \mathrm{cm}$ at a depth of $37 \mathrm{~m}$. It increased slowly and it reached about $183 \mathrm{mS} / \mathrm{cm}$ at a depth of $94 \mathrm{~m}$. 
The T, TDS and EC were illustrated for the fourth profile $\left(S_{1-4}\right)$ in the station 1 (Fig. 5-4 D). The figure showed that the T reading at the surface was $30.16^{\circ} \mathrm{C}$ then as of the other profiles it started decreasing and it reached its maximum value $32.01^{\circ} \mathrm{C}$ at a depth of $19 \mathrm{~m}$. This value of $\mathrm{T}$ started deccreasing with the increase in the depth and it become less and less until it reached its minimum value $24^{\circ} \mathrm{C}$ of this profile at a depth of $88 \mathrm{~m}$.

The illustrating of the TDS results showed that the minimum value was at the surface. This value was $272 \mathrm{~g} / \mathrm{l}$ and it started increasing sharply until reached its maximum value in this profile $429 \mathrm{~g} / \mathrm{l}$ at a depth of $25 \mathrm{~m}$. Then it decreased slowly and it reached $372 \mathrm{~g} / \mathrm{l}$ at a depth of $88 \mathrm{~m}$.

The EC results for this profile showed that the maximum value of the EC 198.4 $\mathrm{mS} / \mathrm{cm}$ was observed at the seawater surface. This EC value decreased gradually with the increase the depth and it reached $179.86 \mathrm{mS} / \mathrm{cm}$ at a depth of $19 \mathrm{~m}$. It decreased sharply until reached $166.86 \mathrm{mS} / \mathrm{cm}$ at a depth of $25 \mathrm{~m}$. After this depth it started increasing slowly down to a depth of $88 \mathrm{~m}$ and it reached $185.18 \mathrm{mS} / \mathrm{cm}$.

TDS VS. EC ,Temp \& Depth $800 \mathrm{~m}$ from coast (Sweimah)

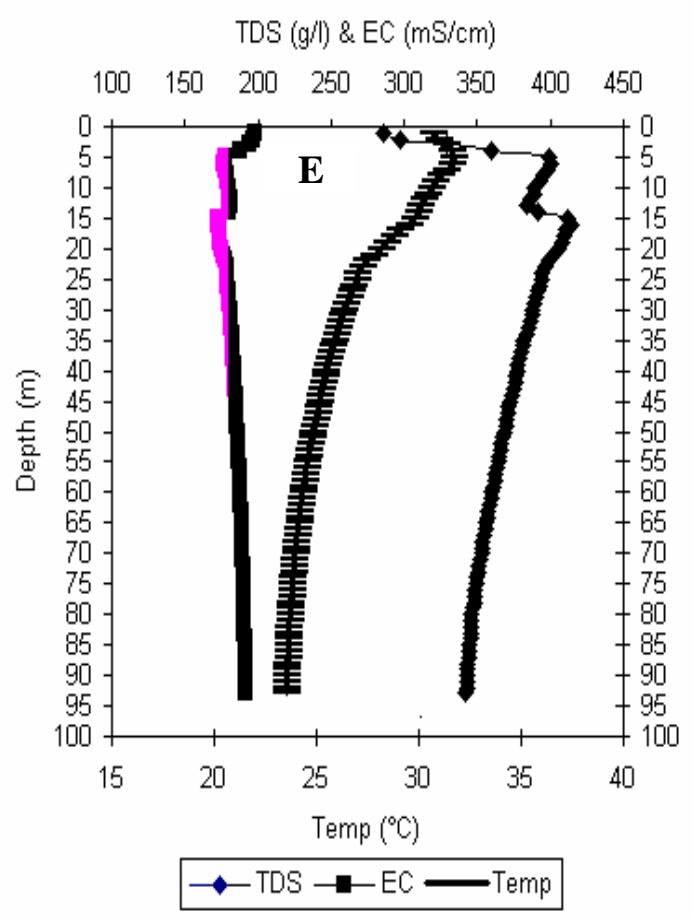

Figure (5-4E): EC, TDS and T Relationship with a depth in Sweimah area at a distance of $800 \mathrm{~m}$ from the shoreline. 
The last profile $\left(S_{1-5}\right)$ at this station located at $800 \mathrm{~m}$ distance away from the shoreline. It demonstrated the results of the T, TDS and EC measurements (Fig. 5$4 \mathrm{E}$ ). The $\mathrm{T}$ profile showed that the surface $\mathrm{T}$ of this profile was $30.7^{\circ} \mathrm{C}$. Then it increased gradually and it reached its maximum value $31.71^{\circ} \mathrm{C}$ at a depth of $5 \mathrm{~m}$ underneath the sea surface. After this depth it decreased and it reached $29.98^{\circ} \mathrm{C}$ at a depth of $14 \mathrm{~m}$. After that it increased slightly and it reached $30.2^{\circ} \mathrm{C}$ at a depth of $16 \mathrm{~m}$. Finally it decreased gradually and it reached its minimum value of this profile $23.52^{\circ} \mathrm{C}$ at a depth of $93 \mathrm{~m}$.

The TDS results showed that its value was $285 \mathrm{~g} / \mathrm{l}$ at the Dead Sea surface. Then it increased sharply with the increase in the depth until reached $400 \mathrm{~g} / \mathrm{l}$ at a depth of $5 \mathrm{~m}$. After that it decreased slowly and it reached $384 \mathrm{~g} / \mathrm{l}$ at a depth of $13 \mathrm{~m}$. After that it increased sharply and it reached its maximum value of this profile 414 $\mathrm{g} / \mathrm{l}$ at a depth of $16 \mathrm{~m}$. Lastly it decreased gradually and it reached $342 \mathrm{~g} / \mathrm{l}$ at a depth of $93 \mathrm{~m}$.

The EC profile in (Fig 5-4 E) showed that the maximum value was $198.1 \mathrm{mS} / \mathrm{cm}$ for the surface seawater. It started decreasing down to a depth of $5 \mathrm{~m}$ and it reached about $177.5 \mathrm{mS} / \mathrm{cm}$. From this depth it increased gradually and it reached 179.92 $\mathrm{mS} / \mathrm{cm}$ at a depth of $16 \mathrm{~m}$. then it decreased sharply and it reached a value of $172.35 \mathrm{mS} / \mathrm{cm}$ at a depth of $16 \mathrm{~m}$. Lastly it increased gradually dowm to a depth of $93 \mathrm{~m}$ until reached a value of $191.55 \mathrm{mS} / \mathrm{cm}$.

The results of the EC, TDS and T with the depth for the profiles at station 2 located in Zarka Ma'in area are illustrating in (Fig. 5-5 F, G, H and J).

The $T$ results of the profile $\left(\mathrm{S}_{2-1}\right)$, which located at $100 \mathrm{~m}$ distance from the shoreline, are summarized in (Fig. 5-5 F). The figure showed that the T of the Dead Sea water at the surface was $38.48^{\circ} \mathrm{C}$. From the surface down to depth of $13 \mathrm{~m}$ underneath sea surface this value decreased gradually and it reached $36.24^{\circ} \mathrm{C}$. It started decreasing sharply at the depth of $14 \mathrm{~m}$ and it reached $35.45^{\circ} \mathrm{C}$ that means the change was about $0.8^{\circ} \mathrm{C}$ within just one-meter change in the depth and this change conceder a significant. From this depth it decreased gradually to a depth of $24 \mathrm{~m}$ and it reached $33.19^{\circ} \mathrm{C}$. Then it decreased sharply and it reached $31.93^{\circ} \mathrm{C}$ at a depth of $26 \mathrm{~m}$. The changed was about $1.26^{\circ} \mathrm{C}$ which conceder also a significant change. Finally it decreased slowly to reach $24.4^{\circ} \mathrm{C}$ at the depth of $80 \mathrm{~m}$ underneath the sea surface.

The TDS results for the same profile showed that the TDS at the surface was 403 $\mathrm{g} / \mathrm{l}$ because the $\mathrm{T}$ was very high at the surface and then the salts consists of the Dead Sea become more soluble. Then the suspension salt dissolved in the seawater. Then the TDS dropped to $385 \mathrm{~g} / \mathrm{l}$ at a depth of $14 \mathrm{~m}$ at the same depth where the T dropped sharply. After that the TDS started increasing gradually and it reached its maximum value $430 \mathrm{~g} / \mathrm{l}$ of this profile at a depth of $25 \mathrm{~m}$ one meter upper the T sharply changed. At last it decreased gradually and it reached $360 \mathrm{~g} / \mathrm{l}$ at a depth of $80 \mathrm{~m}$. 
The EC profile showed that the EC was $176 \mathrm{mS} / \mathrm{cm}$ at the surface seawater. It started increasing slightly and it reached $181.47 \mathrm{mS} / \mathrm{cm}$ at a depth of $13 \mathrm{~m}$ where the TDS dropped down. Then it decreased slightly and it reached $178.9 \mathrm{mS} / \mathrm{cm}$ at a depth of $20 \mathrm{~m}$ then it decreased sharply to reach the lowest value $166.03 \mathrm{mS} / \mathrm{cm}$ of this profile at a depth of $25 \mathrm{~m}$ where the TDS was reached the highest value of this profile. Finally it increased slightly and it reached $188.8 \mathrm{mS} / \mathrm{cm}$ at a depth of 80 $\mathrm{m}$.

The second profile $\left(S_{2-2}\right)$ at the station 2 located at about $200 \mathrm{~m}$ distance from the shoreline (Fig. 5-5 G) showed that the $\mathrm{T}$ value at the sea surface was $33.74^{\circ} \mathrm{C}$. It started decreasing gradually and it reached $31.8^{\circ} \mathrm{C}$ at a depth of $24 \mathrm{~m}$ underneath sea surface. Then it decreased sharply at a depth of $25 \mathrm{~m}$ and it reached $30.9^{\circ} \mathrm{C}$. That mean the changed was about $0.9^{\circ} \mathrm{C}$ within only one meter depth. After this depth the $T$ decreasing slowly and it reached its lowest value $24.08^{\circ} \mathrm{C}$ for this profile at a depth of $91 \mathrm{~m}$.

The TDS value of this profile was $340 \mathrm{~g} / \mathrm{l}$ at the surface, which is the lowest value of this profile. It increased gradually and it reached its maximum value $429 \mathrm{~g} / \mathrm{l}$ in this profile at a depth of $24 \mathrm{~m}$ one meter above the sharply dropping in the T. Then it decreased slowly and it reached $362 \mathrm{~g} / \mathrm{l}$ at a depth of $91 \mathrm{~m}$.

On the other hand the EC profile showed that the EC at the surface was the highest value $192.03 \mathrm{mS} / \mathrm{cm}$ where the TDS was the lowest value of this profile. The EC started decreasing gradually with the increasing in the depth and it reached its lowest value $166.63 \mathrm{mS} / \mathrm{cm}$ at a depth of $24 \mathrm{~m}$ where the TDS was the highest value of this profile. At the last the EC increased slowly and it reached $187.46 \mathrm{mS} / \mathrm{cm}$ at a depth of $91 \mathrm{~m}$ the final depth of this profile. 
TDS VS EC, Temp \& Denth at 100m from coast(Zarka Main)

\section{$\operatorname{TDS}(\mathrm{g}) \mathrm{gl}) \mathrm{EC}(\mathrm{mS} / \mathrm{cm})$}

$150 \quad 200 \quad 250 \quad 300 \quad 350 \quad 400 \quad 450$

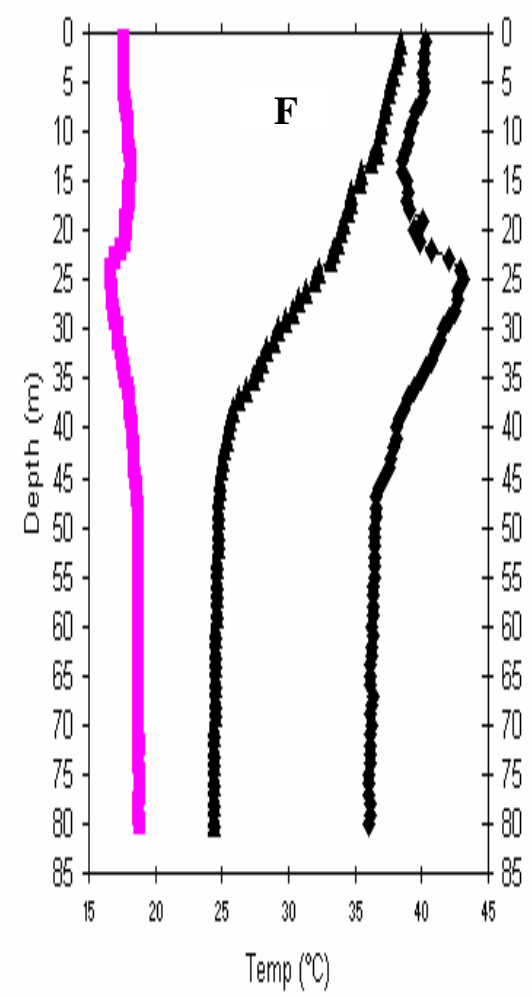

$\rightarrow$ TDS - -EC + TEMP
TDS VSEC, Tem \& Depth 200 m from coast (Zarka Main)

$\operatorname{TDS}(\mathrm{g} /)$ \& EC (mS/cm)

150 $2000250 \quad 300 \quad 350 \quad 400 \quad 450$

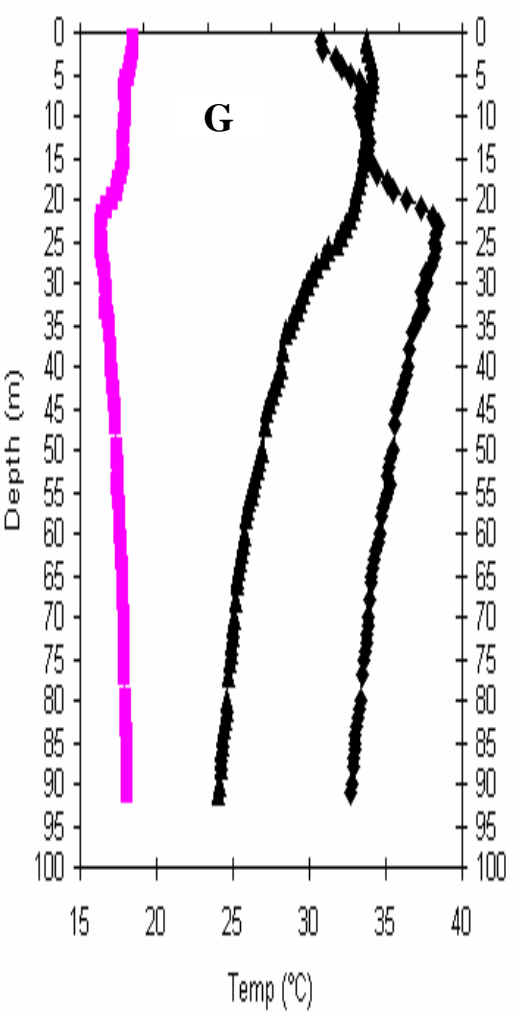

$\rightarrow$ TDS $-1-E C \leftarrow$ TEMP

Figure (5-5F): EC, TDS and T relationship with a depth in Zarka Ma'in area at a distance of $100 \mathrm{~m}$ from the shoreline. Figure (5-5G): EC, TDS and T relationship with a depth in Zarka Ma'in area at a distance of $200 \mathrm{~m}$ from the shoreline.

The third vertical profile $\left(\mathrm{S}_{2-3}\right)$ in station2 (Fig. $5-5 \mathrm{H}$ ) showed that the $\mathrm{T}$ at the surface was $34.04^{\circ} \mathrm{C}$. This value decreased gradually and it reached $31.78^{\circ} \mathrm{C}$ at a depth of $25 \mathrm{~m}$. Then it decreased sharply for about $1^{\circ} \mathrm{C}$ within $1 \mathrm{~m}$ only to reach $30.76^{\circ} \mathrm{C}$ at a depth of $26 \mathrm{~m}$. This sharply changed was affected on the TDS value. After that the $\mathrm{T}$ started decreasing slowly with increasing the depth until the final depth of this profile and it reached its minimum value $24.44^{\circ} \mathrm{C}$ at a depth of $92 \mathrm{~m}$ underneath the sea surface.

The TDS results showed that the minimum value was $342 \mathrm{~g} / \mathrm{l}$ at the surface. Then it increased sharply with increasing depth and it reached its maximum value $436 \mathrm{~g} / \mathrm{l}$ at this profile at a depth of $25 \mathrm{~m}$. This value located one meter above the dropping in the T at $26 \mathrm{~m}$ depth. The TDS values decreased gradually and it reached $360 \mathrm{~g} / \mathrm{l}$ at a depth of $92 \mathrm{~m}$ the final depth of this profile. 
The EC curve of this profile at this station showed that the highest value of EC was $191.48 \mathrm{mS} / \mathrm{cm}$ at the seawater surface. It decreased gradually and it reached about $179.46 \mathrm{mS} / \mathrm{cm}$ at a depth of $15 \mathrm{~m}$ below sea surface. Then it decreased distinctly and it reached $177.77 \mathrm{mS} / \mathrm{cm}$ at a depth of $16 \mathrm{~m}$. It continued decreasing with the increase in the depth and it reached its minimum value $163.85 \mathrm{mS} / \mathrm{cm}$ at a depth of $25 \mathrm{~m}$. This value was at the same depth where the maximum value of the TDS was observed. Then it increased constantly and it reached $187.78 \mathrm{mS} / \mathrm{cm}$ at the final depth of this profile at $92 \mathrm{~m}$.
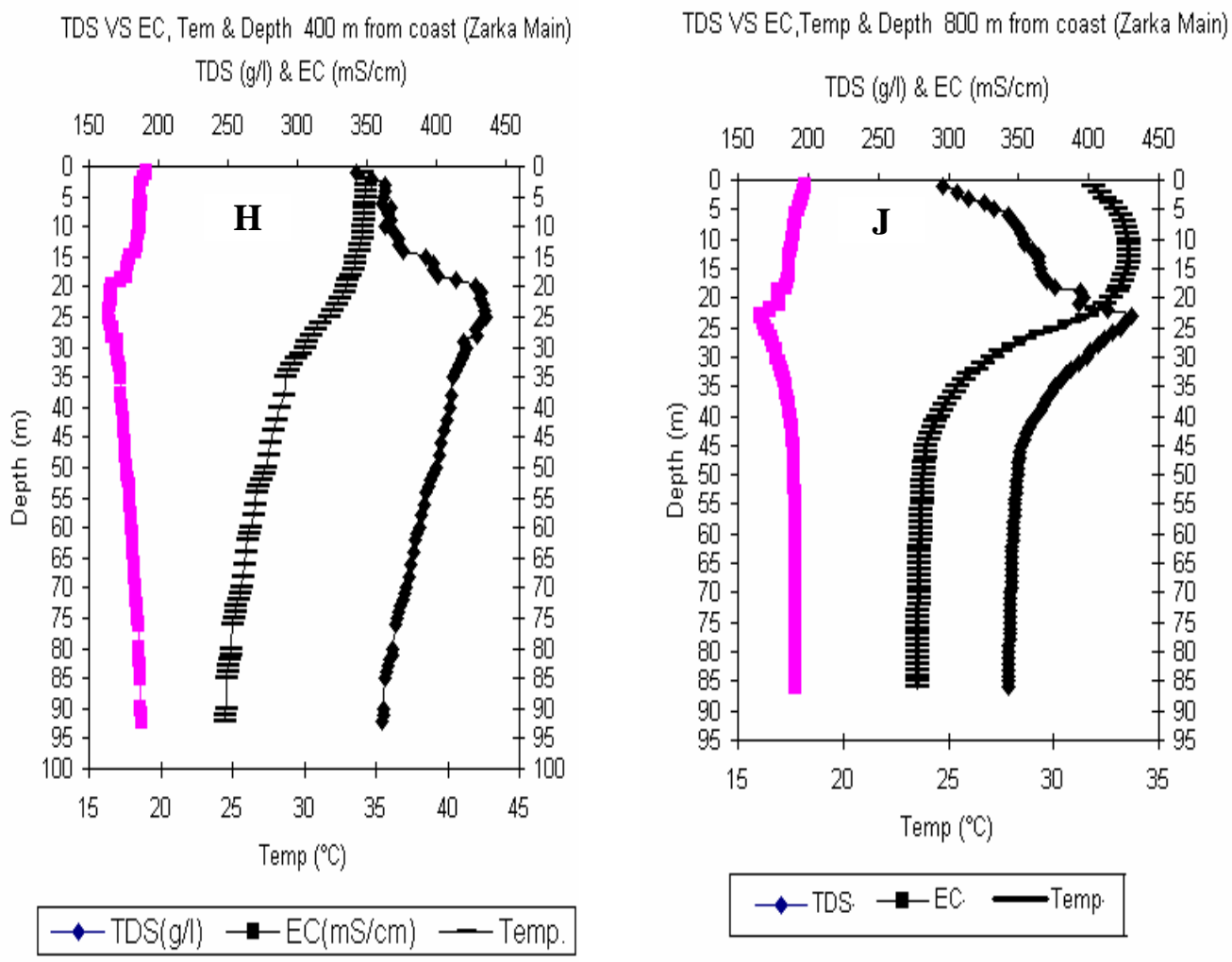

Figure $(5-5 \mathrm{H})$ : EC, TDS and T relationship with a depth in Zarka Ma'in area at a distance of $400 \mathrm{~m}$ from the shoreline. Figure (5-5J): EC, TDS and T relationship with a depth in Zarka Ma'in area at a distance of $800 \mathrm{~m}$ from the shoreline.

Figure (5-5 J) illustrated the results of the T, EC and the TDS for the fourth profile $\left(\mathrm{S}_{2-4}\right)$ at the station 2 in Zarka Ma'in area. The surface $\mathrm{T}$ was $31.91^{\circ} \mathrm{C}$. It started increasing gradually to reach its maximum value $33.59^{\circ} \mathrm{C}$ of this profile at a depth of $12 \mathrm{~m}$ below Dead Sea surface. After that it decreased apparently and it reached to $24.24^{\circ} \mathrm{C}$ at a depth of $42 \mathrm{~m}$. From this depth it decreased very slightly to the final depth $86 \mathrm{~m}$ of this profile and reached to its minimum value $23.5^{\circ} \mathrm{C}$.

The TDS results indicated that the surface seawater salinity was $295 \mathrm{~g} / \mathrm{l}$ which is the lowest value of this profile. This value started increasing rapidly to reach its 
maximum value of this profile $430 \mathrm{~g} / \mathrm{l}$ at a depth of $23 \mathrm{~m}$ directly above the point of the $\mathrm{T}$ rapidly changed. Then it decreased apparently down to $48 \mathrm{~m}$ under sea surface and it reached $350 \mathrm{~g} / \mathrm{l}$. The deeper part of the TDS profile showed that the TDS decreased very slightly almost negligible changes from a depth of $48 \mathrm{~m}$ to the end of this profile at the depth of $86 \mathrm{~m}$ and it reached $342 \mathrm{~g} / \mathrm{l}$ at this depth.

The profile, which illustrated the EC results, showed that the behaviour of the EC changing was in an opposite position of the TDS. The maximum value of the EC of this profile was $197.44 \mathrm{mS} / \mathrm{cm}$ at the surface of seawater that was against the minimum value of the TDS which was $295 \mathrm{~g} / \mathrm{l}$. Then the EC decreased sharply and it reached its minimum value $166.12 \mathrm{mS} / \mathrm{cm}$ of this profile at a depth of $23 \mathrm{~m}$. This value was observed against the maximum value of the TDS of this profile, which was $430 \mathrm{~g} / \mathrm{l}$. After that the EC values started increasing and it reached 190.1 $\mathrm{mS} / \mathrm{cm}$ at a depth of $48 \mathrm{~m}$ below the Dead Sea surface. Then it decreased very slightly with no noticeable changes to reach $191.5 \mathrm{mS} / \mathrm{cm}$ at a depth of $86 \mathrm{~m}$ below Dead Sea surface.

The results of the T, TDS and the EC were plotted related to the depth as in (Fig. 5-6 K, L, M and N) for all profiles at station 3, which located in Zara-Hot springs area. Figure $(5-6 \mathrm{~K})$ illustrated the results of the first profile $\left(\mathrm{S}_{3-1}\right)$. The $\mathrm{T}$ profile showed that the surface $\mathrm{T}$ was very high $43.44^{\circ} \mathrm{C}$. It started decreasing sharply and it reached $38.53^{\circ} \mathrm{C}$ at a depth of $11 \mathrm{~m}$, then it increased slightly between depths $12 \mathrm{~m}$ and $16 \mathrm{~m}$. After that it decreased sharply again and it reached $26.89^{\circ} \mathrm{C}$ at a depth of $51 \mathrm{~m}$. After this depth it decreased slightly to a depth of $84 \mathrm{~m}$ and it reached $24.47^{\circ} \mathrm{C}$.

The TDS plot showed that the TDS at the surface seawater was $445 \mathrm{~g} / \mathrm{l}$. This value was opposite to the very high $T$ value. Then this value started decreasing with a $T$ decreasing, it reached $422 \mathrm{~g} / \mathrm{l}$ at a depth of $11 \mathrm{~m}$ formerly it increased sharply and it reached its maximum value $464 \mathrm{~g} / \mathrm{l}$ at a depth of $15 \mathrm{~m}$. As the other profiles it started decreasing gradually and it reached its minimum value of this profile $367 \mathrm{~g} / \mathrm{l}$ at a depth of $84 \mathrm{~m}$.

The EC at the surface was $159.9 \mathrm{mS} / \mathrm{cm}$ then it reached $170.22 \mathrm{mS} / \mathrm{cm}$ at a depth of $9 \mathrm{~m}$. It started decreasing and it reached its lowest value $151.66 \mathrm{mS} / \mathrm{cm}$ at the depth of $15 \mathrm{~m}$. At the last it started increasing slowly and it reached $186.18 \mathrm{mS} / \mathrm{cm}$ at the end of this profile at a depth of $84 \mathrm{~m}$.

Figure (5-6 L) illustrated the results of the T, TDS and EC with the depth for the second profile $\left(\mathrm{S}_{3-2}\right)$ in station 3. The $\mathrm{T}$ of this profile was $33.3^{\circ} \mathrm{C}$ at the surface, then it increased slowly, and it reached $33.47^{\circ} \mathrm{C}$ at adepth of $8 \mathrm{~m}$. Then a shifting in the $\mathrm{T}$ values occurred at the depths of $12 \mathrm{~m}$ and $19 \mathrm{~m}$. After that it started decreasing to reach its minimum value $24.12^{\circ} \mathrm{C}$ at a depth of $89 \mathrm{~m}$.

The TDS at the surface was $353 \mathrm{~g} / \mathrm{l}$. It increased slightly from the surface to a depth of $8 \mathrm{~m}$ and it reached $362 \mathrm{~g} / \mathrm{l}$. Then it increased sharply at a depth of $12 \mathrm{~m}$ 
where the shifting in T was occurred and it reached $411 \mathrm{~g} / \mathrm{l}$. After that it decreased again and it reached a value of $401 \mathrm{~g} / \mathrm{l}$ at a depth of $19 \mathrm{~m}$ also at the same point where the shifting in T occurred. The TDS increased slightly again and it reached its maximum value $417 \mathrm{~g} / \mathrm{l}$ of this profile at a depth of $25 \mathrm{~m}$ below Dead Sea level. Finally it decreased gradually and it reached $353 \mathrm{~g} / \mathrm{l}$ at a depth of $89 \mathrm{~m}$.

The results of the EC at this profile showed that the EC at the surface was 189.44 $\mathrm{mS} / \mathrm{cm}$. It decreased very slightly and it reached $187.11 \mathrm{mS} / \mathrm{cm}$ at a depth of $9 \mathrm{~m}$. Then sharply decreasing occurred at a depth of $14 \mathrm{~m}$ and it reached 173.38 $\mathrm{mS} / \mathrm{cm}$. Then it increased slightly and it reached $176.56 \mathrm{mS} / \mathrm{cm}$ at a depth of $19 \mathrm{~m}$. It decreased again to a depth of $25 \mathrm{~m}$ and it reached its minimum value 171.03 $\mathrm{mS} / \mathrm{cm}$ at this profile. Finally it increased gradually and it reached $189.31 \mathrm{mS} / \mathrm{cm}$ at a depth of $89 \mathrm{~m}$.

Figure (4-6 M) denoted to the third vertical profile $\left(\mathrm{S}_{3-3}\right)$ which is located at about $400 \mathrm{~m}$ distance away from the shoreline in station 3 . The $T$ results of this profile showed that the $T$ at the surface was $31.08^{\circ} \mathrm{C}$. This value increased gradually with the increase the depth and it reached its maximum value $32.33^{\circ} \mathrm{C}$ of this profile. Thereafter it decreased slightly and it reached $32.04^{\circ} \mathrm{C}$ at a depth of $16 \mathrm{~m}$ below Dead Sea level. Suddenly a shifting of the $T$ value occurred and it decreased from $32.04^{\circ} \mathrm{C}$ at a depth of $16 \mathrm{~m}$ to $31.2^{\circ} \mathrm{C}$ at a depth of $20 \mathrm{~m}$. Then it decreased gradually to a depth of $51 \mathrm{~m}$ and it reached value of $24.31^{\circ} \mathrm{C}$. Finally it decreased very slightly almost negligible changes to a depth of $96 \mathrm{~m}$ and it reached its minimum value $23.42^{\circ} \mathrm{C}$ of this profile. 
TDS VS EC, Temp \& Depth $100 \mathrm{~m}$ from coast (Zara area)

$\operatorname{TDS}(\mathrm{g} / \mathrm{l})$ \& $\mathrm{EC}(\mathrm{mS} / \mathrm{cm})$

$100 \quad 150200250300350400450500$

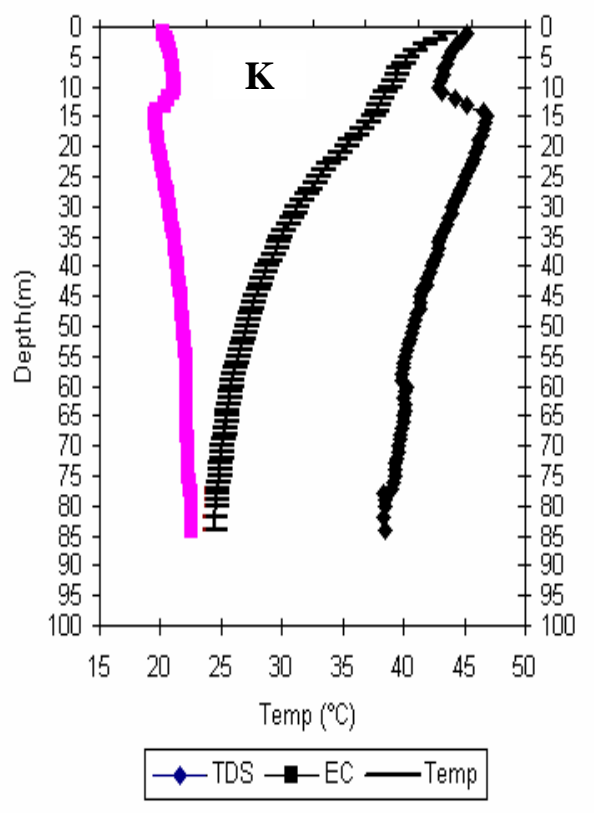

TDS VS EC, Temp \& Depth $300 \mathrm{~m}$ from coast (Zara)

$\operatorname{TDS}(\mathrm{g} / \mathrm{l}) \& \mathrm{EC}(\mathrm{mS} / \mathrm{cm})$

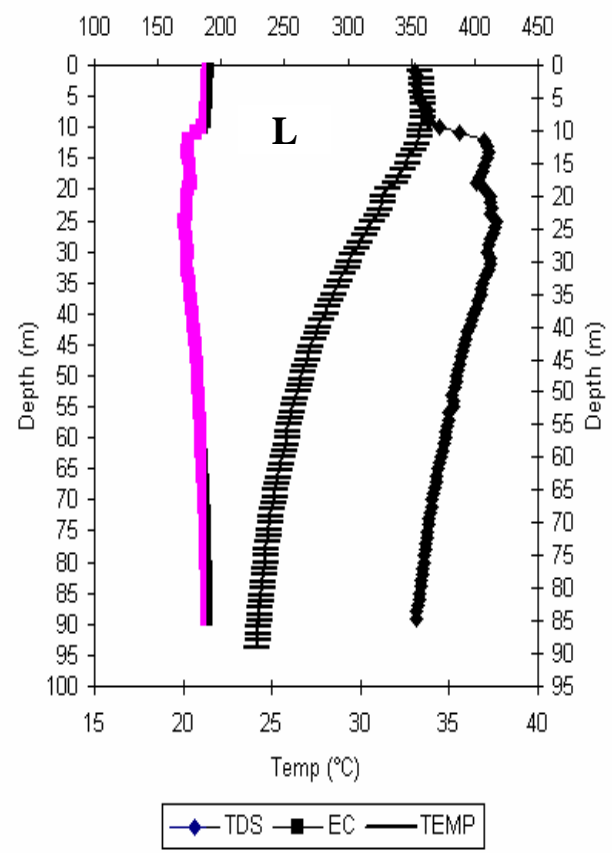

Figure (5-6K): EC, TDS and T relationship with the depth in Zara area at a distance $100 \mathrm{~m}$ from the shoreline. Figure (5-6L): EC, TDS and T with a depth in Zara area at a distance of $300 \mathrm{~m}$ from the shoreline.

The TDS graph in (Fig. 5-6 M) indicated that the TDS of the Dead Sea water at the surface of this profile was $272 \mathrm{~g} / \mathrm{l}$, then a sharply increasing was occurred from the surface to a depth of $13 \mathrm{~m}$ and it reached $396 \mathrm{~g} / \mathrm{l}$ parallel with the increasing in the $T$ values. Thereafter it increased gently and it reached its maximum value $430 \mathrm{~g} / \mathrm{l}$ in this profile at a depth of $17 \mathrm{~m}$ below Dead Sea surface. Then it started decreasing gradually, it reached $358 \mathrm{~g} / \mathrm{l}$ at a depth of $51 \mathrm{~m}$. Lastly it decreased very gently with inconsiderable changes, and it reached a value of $338 \mathrm{~g} / \mathrm{l}$ at a depth of $96 \mathrm{~m}$.

The results of the EC for the same profile showed that the EC at the surface was $198.4 \mathrm{mS} / \mathrm{cm}$. It decreased rapidly to a depth of $13 \mathrm{~m}$ and it reached 178.15 $\mathrm{mS} / \mathrm{cm}$. Thereafter a shifting occurred at this depth and started decreasing gently with increasing the depth, and it reached its minimum value $166.52 \mathrm{mS} / \mathrm{cm}$ at a depth of $17 \mathrm{~m}$. Then it increased gradually until a depth of $51 \mathrm{~m}$ and it reached a value of $188.24 \mathrm{mS} / \mathrm{cm}$. From this depth to the end of this profile the EC increased very slightly with unnoticeable changes and it reached a value of 192.22 at a depth of $96 \mathrm{~m}$. 

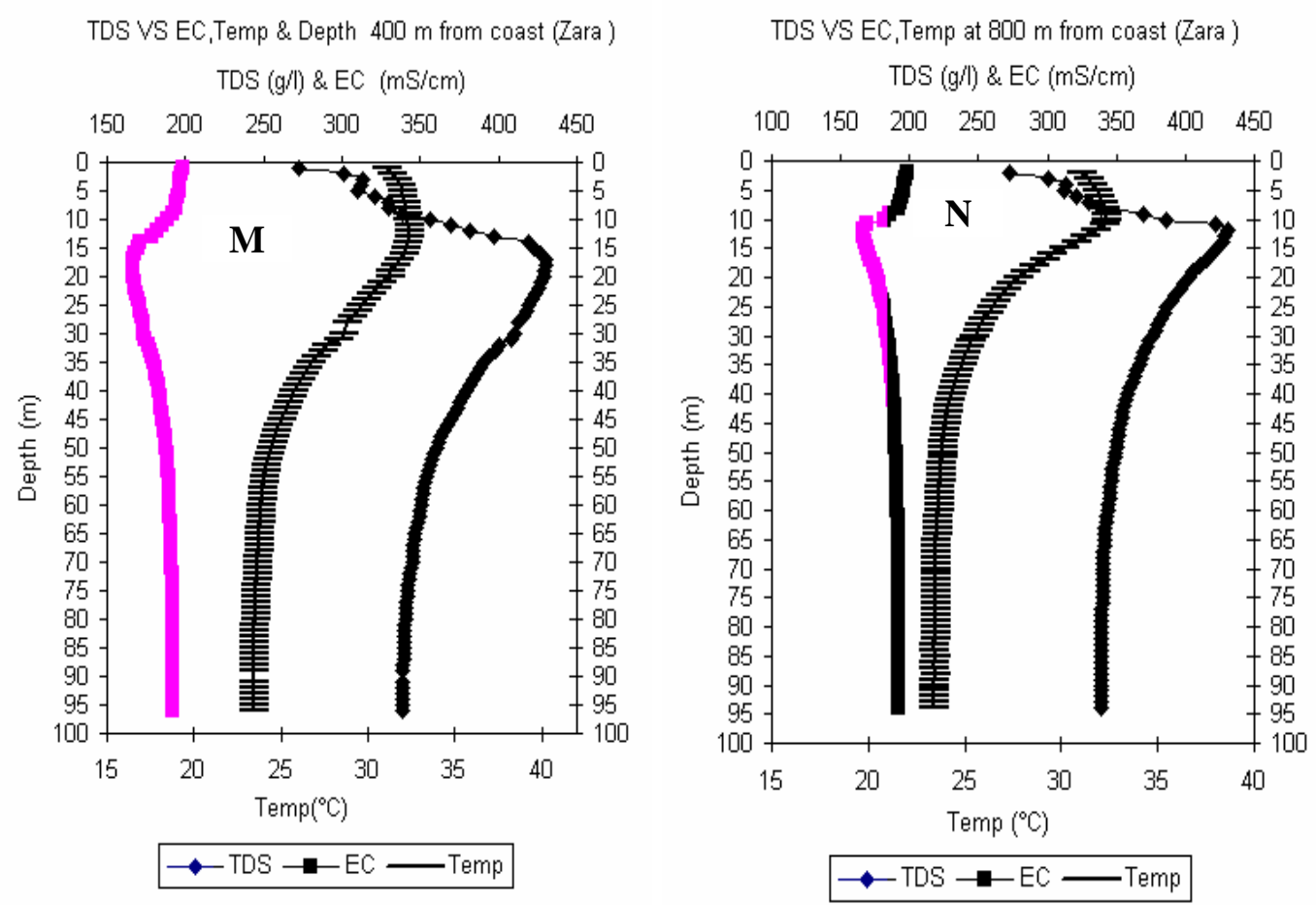

Figure (5-6M): EC, TDS and T relationship with the depth in Zara area at a distance $400 \mathrm{~m}$ from the shoreline. Figure (5-6L): EC, TDS and T with a depth in Zara area at a distance of $800 \mathrm{~m}$ from the shoreline.

The results of the T, TDS and the EC for the vertical profile $\left(S_{3-4}\right)$, which is located at about $800 \mathrm{~m}$ distance away from the shoreline, were plotted into three graphs as shown in (Fig. 5-6 N). The $\mathrm{T}$ at the surface of this profile was $31.08^{\circ} \mathrm{C}$. It increased sharply and it reached its maximum value at $32.37^{\circ} \mathrm{C}$ of this profile at a depth of 10 $\mathrm{m}$, then it decreased gently until a depth of $12 \mathrm{~m}$. At this depth the $\mathrm{T}$ was shifting and decreased sharply from a value of $32.2^{\circ} \mathrm{C}$ to reach $30.16^{\circ} \mathrm{C}$ at a depth of $15 \mathrm{~m}$. Then it decreased gradually to a depth of $47 \mathrm{~m}$ and it reached a value of $23.91^{\circ} \mathrm{C}$. Thereafter it decreased very slightly to the last depth of this profile at $94 \mathrm{~m}$ and it reached its minimum value $23.43^{\circ} \mathrm{C}$.

The TDS at the surface of this profile was $272 \mathrm{~g} / \mathrm{l}$. This value increased sharply parallel with the increase of the $T$ and it reached a value of $386 \mathrm{~g} / \mathrm{l}$ at a depth of 10 $\mathrm{m}$. Thereafter it increased gradually and it reached its maximum value $428 \mathrm{~g} / \mathrm{l}$ at a depth of $12 \mathrm{~m}$ where the shifting of the T occurred. Then it decreased gradually to a depth of $47 \mathrm{~m}$ then it decreased very slightly with unnoticeable changes and it reached a value of $338 \mathrm{~g} / \mathrm{l}$ at a depth of $94 \mathrm{~m}$. 
The results of EC showed that the $E C$ at the surface was $198.4 \mathrm{mS} / \mathrm{cm}$. It decreased gradually and it reached its minimum value $166.86 \mathrm{mS} / \mathrm{cm}$ of this profile at a depth of $13 \mathrm{~m}$ below sea surface. After that it increased slowly to a depth of 47 $\mathrm{m}$. Then it increased very slightly with inconsiderable changes until a depth of $94 \mathrm{~m}$ and it reached a value of $192.18 \mathrm{mS} / \mathrm{cm}$.

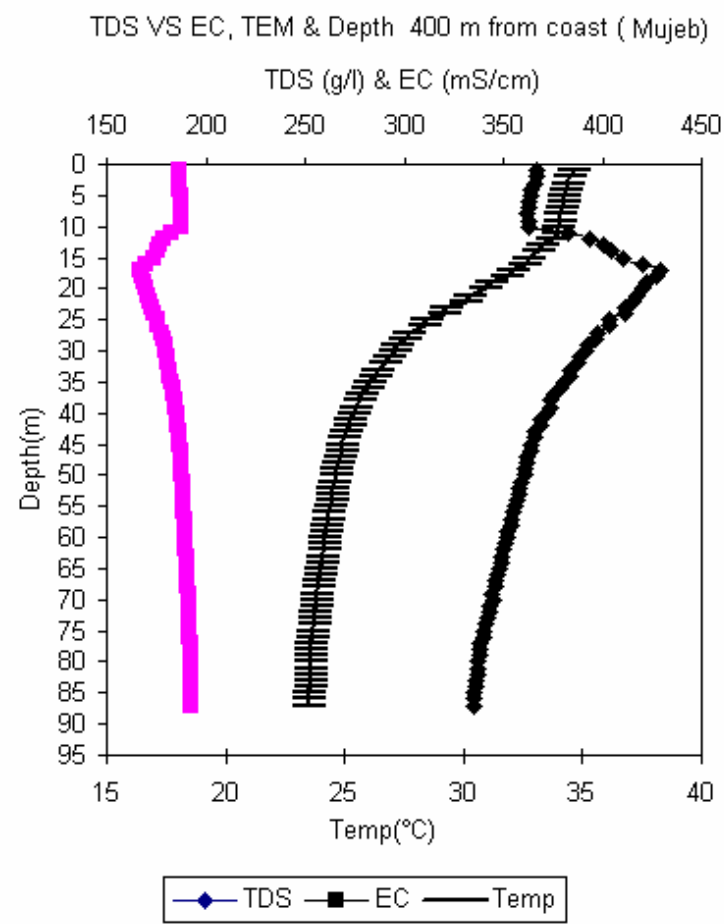

Figure (5-7): EC, TDS and T relationship with the depth in Mujeb area at a distanse of $400 \mathrm{~m}$ from the shoreline.

The results of T, TDS and EC for the vertical profiles at station 4, which located in Mujeb area, are shown in (Fig. 5-7). The T profile showed that the $\mathrm{T}$ at the Dead Sea water surface was $34.51^{\circ} \mathrm{C}$. This value changed very slightly and conceder a negligible change to a depth of $10 \mathrm{~m}$. At a depth of $12 \mathrm{~m}$ a shifting change occurred and it decreased sharply to a depth of $43 \mathrm{~m}$ and it reached $25.03^{\circ} \mathrm{C}$. Finally it continued decreasing but very slightly to a depth of $87 \mathrm{~m}$ and it reached $23.51^{\circ} \mathrm{C}$.

On the other hand the TDS profile showed that the surface salinity was $366 \mathrm{~g} / \mathrm{l}$. This value did not change or very slightly changed until the depth of $10 \mathrm{~m}$, thereafter it increased rabidly after this depth. At $11 \mathrm{~m}$ it reached its maximum value at a depth of $18 \mathrm{~m}$ below the sea surface. Finally it decreased gradually to the final depth of this profile at $87 \mathrm{~m}$ and it reached to $335 \mathrm{~g} / \mathrm{l}$. 
The EC profile showed that the EC at the surface was $186.4 \mathrm{mS} / \mathrm{cm}$. This value did not change also as the T and TDS profiles or the changes were very slightly and unnoticeable until $10 \mathrm{~m}$ depth. From $11 \mathrm{~m}$ it changed rapidly and continued decreasing and it reached its minimum value 167.38 at a depth of $18 \mathrm{~m}$. At the last it increased gradually and it reached $192.67 \mathrm{mS} / \mathrm{cm}$ at a depth of $87 \mathrm{~m}$ below the sea surface. The detailed results for all stations and all profiles are illustrated in (Appendix II).

The above results of T, TDS and EC with the depth can be inerpretated as follows:

The above results showed that the Dead Sea water divides into two layers in summer time and the border between the layers was observed. The upper layer was subdivided into two sub layers (members). The upper most member was different in its thickness related to the distance from the shore and the locations along the shoreline. This upper member characterized with a high temperature, low total dissolved solids and high electrical conductivity. The second member characterized by a very high TDS and the lowest in EC.

The thickness of the upper layer is different. It depends on the distance of the profile from the shoreline and the location. Generally the total thickness of this layer include both members was between 16 and $40 \mathrm{~m}$. The lower layer located beneath the upper layer and it extends from $40 \mathrm{~m}$ in average to the final depth of the profiles. The lower layer characterizes with low $T$ and moderate EC and TDS.

The upper layer of the Dead Sea is considered in this study with giving more pay attention to the upper member, because the submarine groundwater is discharged into the Dead Sea at this member as shown in the above results (Figs. 5-4, 5-5, 56 and 5-7). In station1 in Sweimah area the thickness of the upper member is $16 \mathrm{~m}$ in average and the groundwater discharged at the upper $16 \mathrm{~m}$ of the Dead Sea, while the upper member of the Dead Sea thickness in Zarka Ma'in area is $25 \mathrm{~m}$ in average and the groundwater discharged into the Dead Sea in the upper $25 \mathrm{~m}$. On the other hand this upper member in station3 in Zara area is $15 \mathrm{~m}$ and the groundwater discharged into the Dead Sea in this area in the upper $15 \mathrm{~m}$. Finally the thickness of the upper member in station4 in Mujeb area is $18 \mathrm{~m}$. The groundwater discharged into the Dead Sea in this area in the upper $18 \mathrm{~m}$.

Generally the vertical zones of the discharge into the Dead Sea indicated with a high EC and a low TDS. These results were supported by using the curve in (Fig. 5-2) above.

The T profiles in the (Fig. 5-5 to 5-7) showed that the surface temperatures for the profiles located near the shore was higher than that in the profiles located away from the shoreline, that is because of the thickness of the water layer for the profiles located close to the shores are less than that for the profiles located away from the shore then the solar heating is higher. So the TDS at the surface of all profiles is higher near the shore and lower for the profiles located away from the 
shoreline because of the TDS increases with the increasing in temperature. In most of profiles the direct relationship between the TDS and the T is obvious. In other words the TDS is increasing with increasing in T and vice versa. Temperatures for the upper layer in summer are higher than that for the lower layer. The T of the lower layer decreases in the downward direction for all profiles.

On the other hand the inverse relationship between TDS and EC is clear for all the profiles in all stations. This means that in the Dead Sea the TDS are increases when EC decreases. These findings are supported with the findings from the laboratory experiments.

For Interpretation the reason of why the salinity of the second lower member is higher than that of the upper member and higher than that of the lower layer. The following interpretation was suggested:

Because the measurements were carried out during the summer at the end of July, there were no rain between March and July and the temperature was very high at the Dead Sea area at that time. So the evaporation during these four months was very high. As a result the salinity of the surface water of the Dead Sea becomes higher than that for the layer underneath where the fresh groundwater inflows into the Dead Sea. This water floats (upwellings) to the surface and the denser layer at the surface sinks to the depth beneath places where the groundwater discharge happening.

To support this suggestion the densities of the standard salts, which discussed above in this section (table 5-4) were used. The following calculations were done and then it was compared with the ratio between the regular seawater at $0^{\circ} \mathrm{C}$ and $4^{\circ} \mathrm{C}$.

The following weights of salts were added for preparing the initial standard solution $(380 \mathrm{~g} / \mathrm{l})$ :

$203 \mathrm{~g} / \mathrm{l}$ of $\mathrm{MgCl}_{2}, 83 \mathrm{~g} / \mathrm{l}$ of $\mathrm{NaCl}$ and $62.24 \mathrm{~g} / \mathrm{l}$ of $\mathrm{CaCl}_{2}$ if these weights were transferred to percentages then these values equivalent to:

$\mathrm{MgCl}_{2}=203 / 380=0.53421$

$\mathrm{NaCl}=83 / 380=0.21842$

$\mathrm{CaCl}_{2}=62.24 / 380=0.1638$

First the value of the maximum TDS was suggested to be $450 \mathrm{~g} / \mathrm{l}$ then we need to add $70 \mathrm{~g} / \mathrm{l}$ to the initial solution from these three salts to get this value of TDS. Then the weights needed from these salts were calculated as follows:

$\mathrm{MgCl}_{2}(\mathrm{~g} / \mathrm{l})=0.53421^{*} 70=37.39$ 
$\mathrm{NaCl} \quad(\mathrm{g} / \mathrm{l})=0.21842^{*} 70=15.29$

$\mathrm{CaCl}_{2}(\mathrm{~g} / \mathrm{l})=0.1638^{*} 70=11.47$

The relationship between the TDS and the densities that discussed in the previous section was plotted as in (Fig. 4-8) and then these curves were used for estimating the density of each added salt.

Then the TDS values after adding each salt to the initial standard salt solution was calculated as follows:

$\mathrm{MgCl}_{2}(\mathrm{~g} / \mathrm{l})=380+37.39=417.39$

The density was $1.2609 \mathrm{~g} / \mathrm{cm}^{3}$

$\mathrm{NaCl} \quad(g / l)=380+15.29=395.29$

The density was $1.2598 \mathrm{~g} / \mathrm{cm} 3$

$\mathrm{CaCl}_{2}(\mathrm{~g} / \mathrm{l})=380+11.47=391.47$

The density was $1.2522 \mathrm{~g} / \mathrm{cm}^{3}$

The density of the initial standard salts solution was $1.2472 \mathrm{~g} / \mathrm{cm}^{3}$

Then the differences of the densities between each salt and the density of the initial standard salt were calculated as follows:

For $\mathrm{Mg} \mathrm{Cl}_{2}=1.2609-1.2472=0.0137 \mathrm{~g} / \mathrm{cm}^{3}$,

For $\mathrm{NaCl}=1.2598-1.2472=0.0126 \mathrm{~g} / \mathrm{cm}^{3}$,

For $\mathrm{CaCl}_{2}=1.2522-1.2472=0.005 \mathrm{~g} / \mathrm{cm}^{3}$.

The total of densities differences for the three salts was

$0.0137+0.0126+0.005=0.0313 \mathrm{~g} / \mathrm{cm}^{3}$

Then the density of the solution with $450 \mathrm{~g} / \mathrm{l}$ was

$1.2472+0.0313=1.2785 \mathrm{~g} / \mathrm{cm}^{3}$

Finally the density of solution with TDS $450 \mathrm{~g} / \mathrm{l}$ and the density of the intial solution with TDS $380 \mathrm{~g} / \mathrm{l}$ ratio were:

$1.2785 / 1.2472=1.0251$ 
Then this ratio was compared with the ratio between the sea water at $0^{\circ} \mathrm{C}$ and $4^{\circ} \mathrm{C}$ which is equal

$1.0001994 / 1.0000966=1.0001$ where the density of the water at $0^{\circ} \mathrm{C}$ is 1.0000966 $\mathrm{g} / \mathrm{cm}^{3}$ and the density of water at $4^{\circ} \mathrm{C}$ is 1.0001994 .

Then the results showed that the ratio between the density of the salt solution with TDS $450 \mathrm{~g} / \mathrm{l}$ and density of the solution with TDS $380 \mathrm{~g} / \mathrm{l}$ was larger than that ratio between the ocean water at the temperature $4^{\circ} \mathrm{C}$ and $0^{\circ} \mathrm{C}$

As well the same procedure were done for the salt solution with TDS $420 \mathrm{~g} / \mathrm{l}$ the ratio was found as 1.00922 and this ratio also larger than the ratio between the Ocean water at $4^{\circ} \mathrm{C}$ and $0^{\circ} \mathrm{C}$ then as a result because the water at $4^{\circ} \mathrm{C}$ sink beneath water at $0^{\circ} \mathrm{C}$ then the salt solution with TDS $450 \mathrm{~g} / \mathrm{l}$ or $420 \mathrm{~g} / \mathrm{l}$ will sink beneath a salt solution with TDS $380 \mathrm{~g} / \mathrm{l}$.

Density VS Total disolved solids

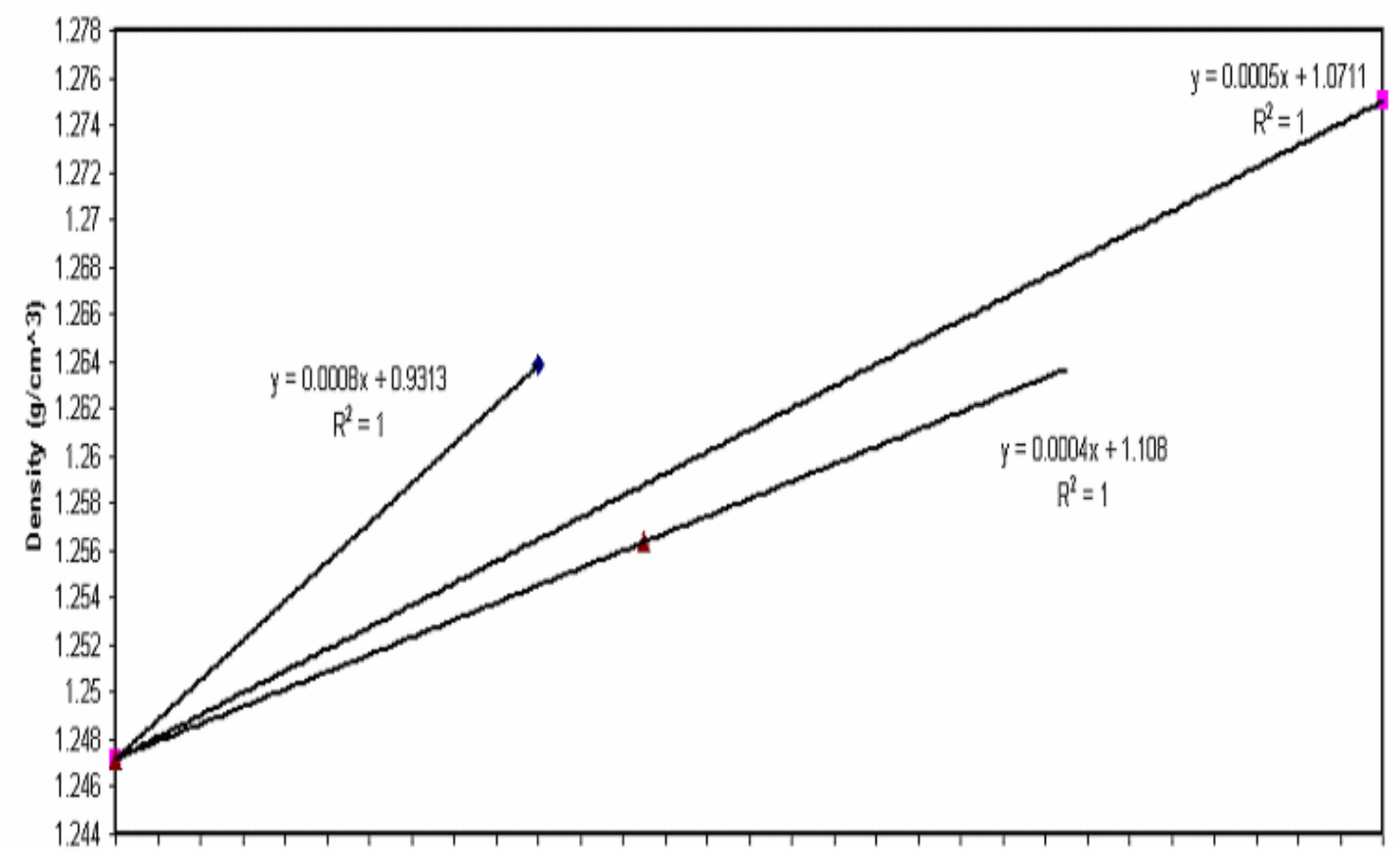

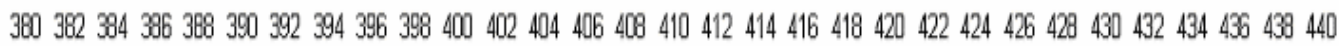

Total dissolved solids $(g / l)$

- $\mathrm{NaCl} \| \mathrm{CaCl} 2.2 \mathrm{H} 2 \mathrm{~A} \mathrm{MgCl} 2 \mathrm{MgCl}-\mathrm{NaCl}-\mathrm{CaCl} 2.2 \mathrm{H} 2 \mathrm{O}$

Figure (5-8): Relationship between TDS and densities of the standard salts solution 


\subsection{Chemical Tracer (Radon-222)}

The long of zone of ground water discharge in Sweimah area (station1) is about 7 $\mathrm{km}$, for Zarka Ma'in and Zara (station2 and station3) is about $5 \mathrm{~km}$ and in Mujeb area (station4) is about $5 \mathrm{~km}$ figure (5-9).

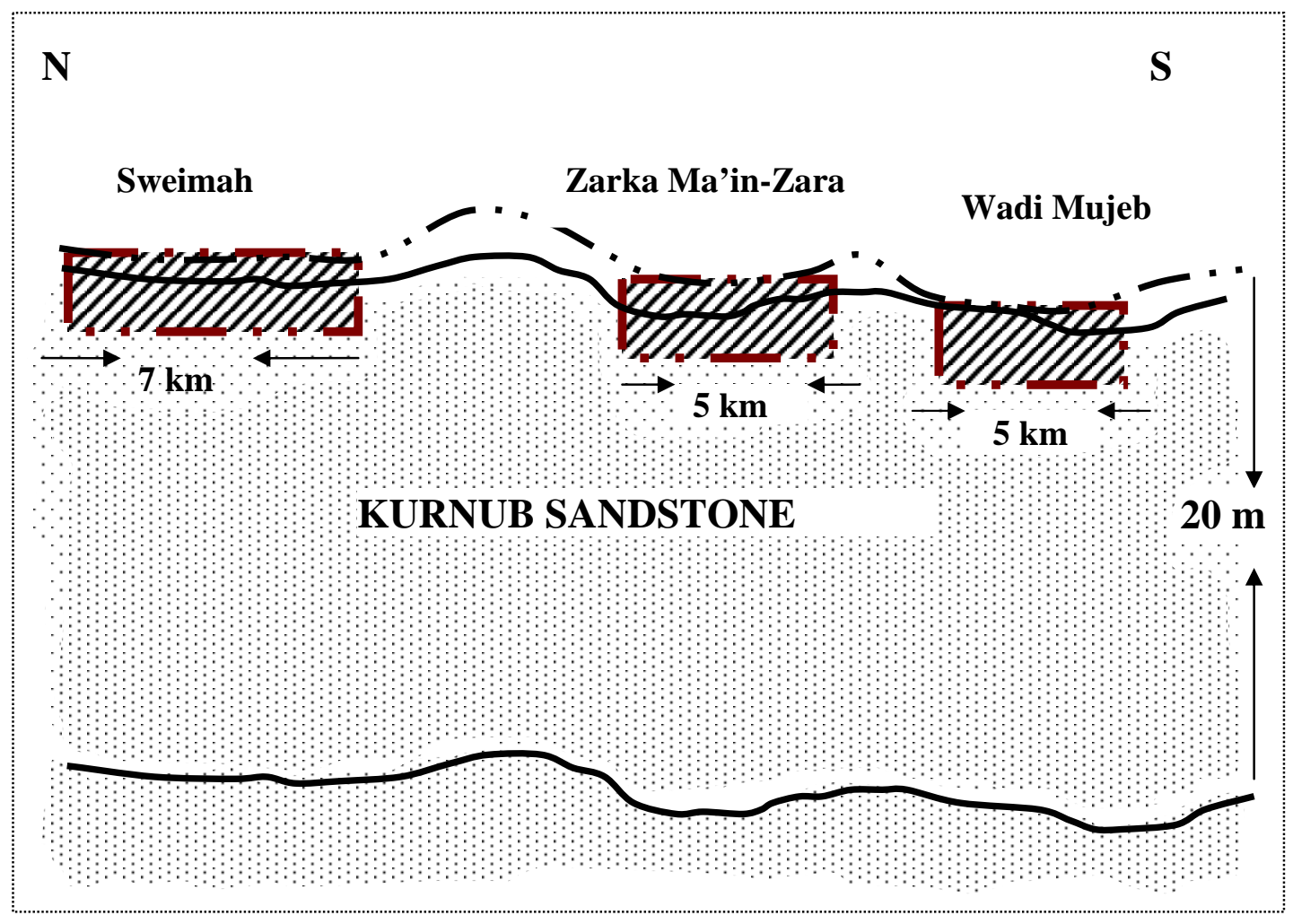

Fig. (5-9): Sketch diagram for the zones of discharge along the DS

In station $1\left(S_{\mathrm{rnn}}\right)$ located in Sweimah area at the northeastern corner of the Dead Sea, the total ${ }^{222} \mathrm{Rn}$ concentration at the depth profile in the water column at the distance $20 \mathrm{~m}$ away from the shoreline reached its maximum concentration 2520 Bq. $\mathrm{m}^{-3}\left(151200 \mathrm{dpm} \cdot \mathrm{m}^{-3}\right)$ at depth $12 \mathrm{~m}$ underneath the sea surface. This concentration decreased up-ward and downward of this depth. It reached to about $1740 \mathrm{~Bq} \cdot \mathrm{m}^{-3}$ at depth of $20 \mathrm{~m}, 1580 \mathrm{~Bq} \cdot \mathrm{m}^{-3}$ at the depth of $7 \mathrm{~m}, 1890 \mathrm{~Bq} \cdot \mathrm{m}^{-3}$ at the depth of $4 \mathrm{~m}$ and it reached to 1140 Bq. $\mathrm{m}^{-3}$ at the depth of $2 \mathrm{~m}$ underneath of sea surface. These results will be used to calculate the ${ }^{222} \mathrm{Rn}$ decay, diffusion, and advection. The other samples results at this area around the main station showed that:

In the area located to the north of the main station with a distance about $800 \mathrm{~m}$. The concentration was about 2190 at depth of $12 \mathrm{~m}$ and a distance about $50 \mathrm{~m}$ away from the shoreline, $1230 \mathrm{~Bq} \cdot \mathrm{m}^{-3}$ at the depth of $12 \mathrm{~m}$ and distance about 200 $\mathrm{m}$ from the shoreline, about $1950 \mathrm{~Bq} \cdot \mathrm{m}^{-3}$ at depth of $12 \mathrm{~m}$ and a distance of $300 \mathrm{~m}$ 
away from the shoreline to the west. It concentration was about $2140 \mathrm{~Bq} \cdot \mathrm{m}^{-3}$ at the distance about $1000 \mathrm{~m}$ to the north of the main station and about $200 \mathrm{~m}$ away from the shoreline. At a location south of the main station with about $4500 \mathrm{~m}$ the results showed that the concentration was $2150 \mathrm{~Bq} \cdot \mathrm{m}^{-3}$ at the distance of about $60 \mathrm{~m}$ away from the shoreline at the depth $12 \mathrm{~m}$ underneath the sea water and about $1300 \mathrm{~Bq} \cdot \mathrm{m}^{-3}$ at depth of $20 \mathrm{~m}$ at the same distance away from the shoreline. At a depth of $12 \mathrm{~m}$ and distance of about $200 \mathrm{~m}$ away from the shoreline the concentration was $1440 \mathrm{~Bq} \cdot \mathrm{m}^{-3}$. On the other hand the concentration was 1310 Bq. $\mathrm{m}^{-3}$ at the same location but the distance about $300 \mathrm{~m}$ away from the shoreline, and at about $700 \mathrm{~m}$ away from the shoreline the concentration was $1150 \mathrm{~Bq} \cdot \mathrm{m}^{-3}$.

The results at the main station $2\left(\mathrm{~S}_{\mathrm{rn} 2}\right)$ which located in Zarka Ma'in area a distance of about $25 \mathrm{~m}$ away from the shoreline showed that the maximum ${ }^{222} \mathrm{Rn}$ concentration was $2180 \mathrm{~Bq} \cdot \mathrm{m}^{-3}\left(130800 \mathrm{dpm} \cdot \mathrm{m}^{-3}\right)$ at depth of $7 \mathrm{~m}$. It reached to about $1870 \mathrm{~Bq} \cdot \mathrm{m}^{-3}$ at a depth of $12 \mathrm{~m}$, about $1310 \mathrm{~Bq} \cdot \mathrm{m}^{-3}$ at a depth of $24 \mathrm{~m}$ underneath the Dead Sea level, about $2080 \mathrm{~Bq} \cdot \mathrm{m}^{-3}$ at a depth of $4 \mathrm{~m}$ and about 870 Bq. $\mathrm{m}^{-3}$ at $2 \mathrm{~m}$ depth beneath the sea surface. These results also will be used calculate the radon-222 inventory (decay), diffusion and advection. As well the other samples analyzed at different distance from the main station and different distances away from the shoreline showed that the ${ }^{222} \mathrm{Rn}$ concentration at same location of the main station but at the distance of $10 \mathrm{~m}$ away from the shoreline and a depth of $4 \mathrm{~m}$ the ${ }^{222} \mathrm{Rn}$ concentration was $2140 \mathrm{~Bq} \cdot \mathrm{m}^{-3}$. It was $2060 \mathrm{~Bq} \cdot \mathrm{m}^{-3}$ at distance about $40 \mathrm{~m}$ away from the shoreline. But at the location far away from the main station with about $300 \mathrm{~m}$ to the north the ${ }^{222} \mathrm{Rn}$ concentration was $1960 \mathrm{~Bq} \cdot \mathrm{m}^{-}$ ${ }^{3}$ at the distance of about $10 \mathrm{~m}$ away from the shoreline and at a depth of about 4 $\mathrm{m}$ and about 680 Bq. $\mathrm{m}^{-3}$ at the distance of about $40 \mathrm{~m}$ away from the shoreline and at a depth of $4 \mathrm{~m}$ underneath the sea surface. On the other hand the concentration was about 2220 Bq. $\mathrm{m}^{-3}$ at the location about $800 \mathrm{~m}$ north of the main station, about $10 \mathrm{~m}$ away from the shoreline and depth of $4 \mathrm{~m}$.

The maximum concentration of ${ }^{222} \mathrm{Rn}$ in the main station $3\left(\mathrm{~S}_{\mathrm{rn} 3}\right)$ at distance of about $25 \mathrm{~m}$ away from the shoreline was $1780 \mathrm{~Bq} \cdot \mathrm{m}^{-3}\left(106800 \mathrm{dpm} \cdot \mathrm{m}^{-3}\right)$ at a depth of $12 \mathrm{~m}$. It decreased to $1000 \mathrm{~Bq} \cdot \mathrm{m}^{-3}$ at a depth of $24 \mathrm{~m}$ underneath the sea surface, and $1690 \mathrm{~Bq} \cdot \mathrm{m}^{-3}$ at the depth of $7 \mathrm{~m}$. It was $1530 \mathrm{~Bq} \cdot \mathrm{m}^{-3}$ at a depth of $4 \mathrm{~m}$ and $1290 \mathrm{~Bq} \cdot \mathrm{m}^{-3}$ at a depth of $2 \mathrm{~m}$ below the sea surface. To the west of this main station the concentration was 1070 Bq. $\mathrm{m}^{-3}$ at depth of $12 \mathrm{~m}$ and at a distance of about $50 \mathrm{~m}$ away from the shoreline. As well the concentration at a location of 150 $\mathrm{m}$ north of the main station was $2520 \mathrm{~Bq} \cdot \mathrm{m}^{-3}$ at a depth $12 \mathrm{~m}$ and a distance about $15 \mathrm{~m}$ away from the shoreline and it was $1930 \mathrm{~Bq} \cdot \mathrm{m}^{-3}$ at a depth of $12 \mathrm{~m}$ and a distance about $30 \mathrm{~m}$ away from the shoreline. On the other hand at the location of about $500 \mathrm{~m}$ to the north of the main station the radon-222 concentration was 1560 Bq. $\mathrm{m}^{-3}$ at a depth of $12 \mathrm{~m}$ and at a distance of about $20 \mathrm{~m}$ away from the shoreline and it was $1230 \mathrm{~Bq} \cdot \mathrm{m}^{-3}$ at a depth $12 \mathrm{~m}$ and a distance of about $50 \mathrm{~m}$ away from the shoreline at this location. At the location about $500 \mathrm{~m}$ south of the main station3 the concentration was $2240 \mathrm{~Bq} \cdot \mathrm{m}^{-3}$ at the depth of $12 \mathrm{~m}$ and a distance of 
about $20 \mathrm{~m}$ away from the shoreline. It was $1910 \mathrm{~Bq} \cdot \mathrm{m}^{-3}$ at a depth of $12 \mathrm{~m}$ and a distance of about $40 \mathrm{~m}$ away from the shoreline. At this location at a depth of $4 \mathrm{~m}$ and distance of about $20 \mathrm{~m}$ away from the shoreline the concentration was 2100 Bq. $\mathrm{m}^{-3}$, at the distance of $30 \mathrm{~m}$ away from the shoreline the concentration was $1900 \mathrm{~Bq} \cdot \mathrm{m}^{-3}$ at $4 \mathrm{~m}$ depth and it was $1390 \mathrm{~Bq} \cdot \mathrm{m}^{-3}$ at a depth of $4 \mathrm{~m}$ and distance of about $40 \mathrm{~m}$ away from the shoreline. It was $710 \mathrm{~Bq} \cdot \mathrm{m}^{-3}$ at a distance of about $50 \mathrm{~m}$ away from the shoreline and depth of $4 \mathrm{~m}$ at this location. At a location of about $1000 \mathrm{~m}$ south of the main station the ${ }^{222} \mathrm{Rn}$ concentration at a depth of $12 \mathrm{~m}$ was $2700 \mathrm{~Bq} \cdot \mathrm{m}^{-3}, 2200 \mathrm{~Bq} \cdot \mathrm{m}^{-3}$ and $1440 \mathrm{~Bq} \cdot \mathrm{m}^{-3}$ at a distances of about $20 \mathrm{~m}, 50 \mathrm{~m}$ and $200 \mathrm{~m}$ away from the shoreline respectively. The concentration at a location about $2500 \mathrm{~m}$ south of the main station 3 was $2790 \mathrm{~Bq} \cdot \mathrm{m}^{-3}$ at a depth of $12 \mathrm{~m}$ and a distance of about $20 \mathrm{~m}$ away from the shoreline.

In the station4 $\left(\mathrm{S}_{\mathrm{rn} 4}\right)$, which was located in Mujeb area, the ${ }^{222} \mathrm{Rn}$ concentration at a distance of about $25 \mathrm{~m}$ away from the shoreline was $640 \mathrm{~Bq} \cdot \mathrm{m}^{-3}\left(38400 \mathrm{dpm} \cdot \mathrm{m}^{-3}\right.$ ) at depth of $2 \mathrm{~m}$ underneath the Dead Sea surface, $990 \mathrm{~Bq} \cdot \mathrm{m}^{-3}\left(59400 \mathrm{dpm} \cdot \mathrm{m}^{-3}\right)$ at a depth of $4 \mathrm{~m}, 670 \mathrm{~Bq} \cdot \mathrm{m}^{-3}\left(40200 \mathrm{dpm} \cdot \mathrm{m}^{-3}\right)$ at a depth of $7 \mathrm{~m}$, the maximum concentration was 1780 Bq. $\mathrm{m}^{-3}\left(106800 \mathrm{dpm} \cdot \mathrm{m}^{-3}\right)$ at a depth of $12 \mathrm{~m}$ and it was $820 \mathrm{~Bq} \cdot \mathrm{m}^{-3}\left(49200 \mathrm{dpm} \cdot \mathrm{m}^{-3}\right)$ at the depth of $24 \mathrm{~m}$ underneath the sea surface. All the results of radon-222 concentrations are illustrated in (Appendix III).

The concentration values at the depth of $2 \mathrm{~m}$ and $7 \mathrm{~m}$ at station3, and Station 2 at $2 \mathrm{~m}$ depth were not representative because the internal humidity of RAD7 was higher than that required. It was about $35 \%$ but it must be equal or less than $10 \%$.

The radon-222 concentration results in the main four stations are plotted in (Fig. 510). 


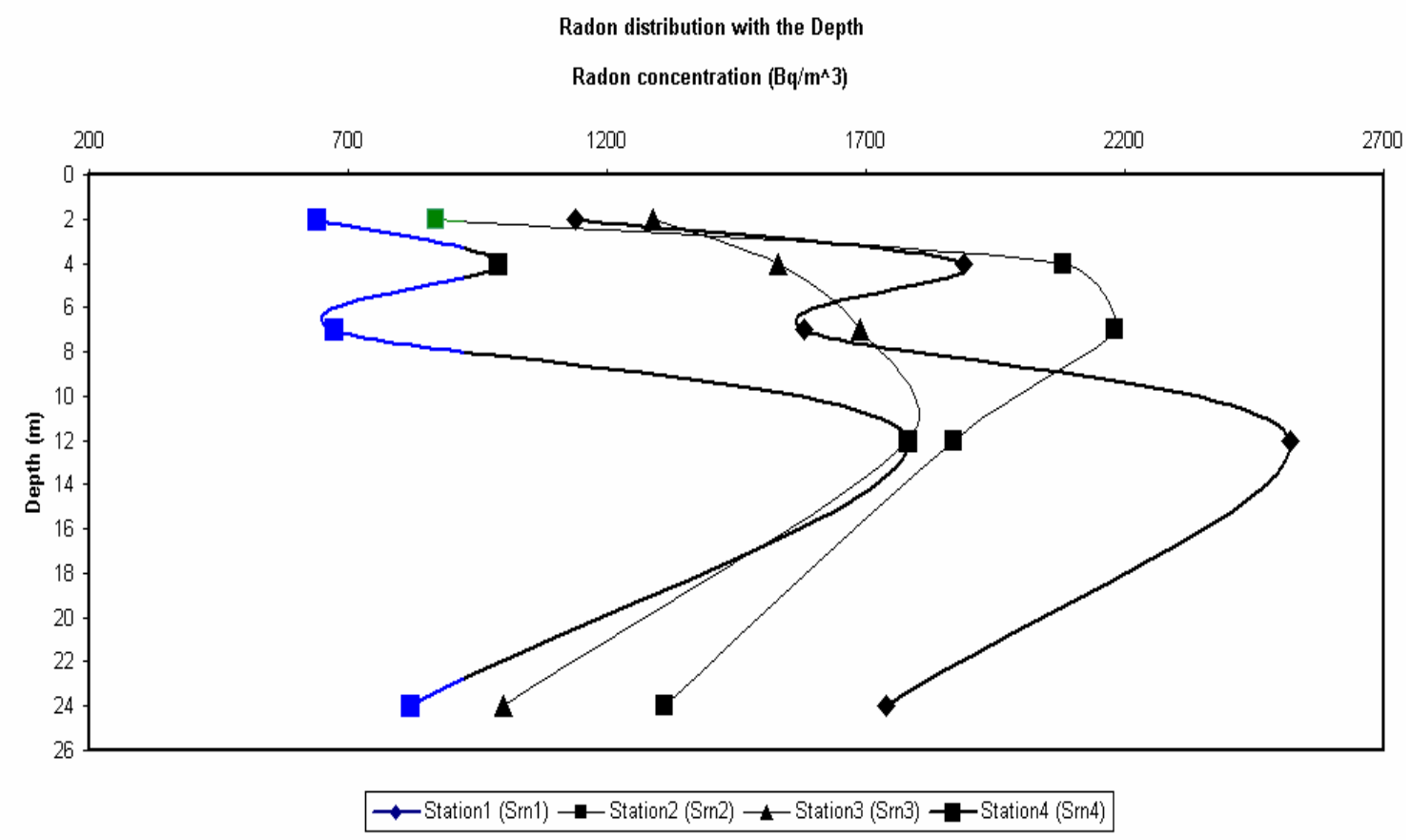

Figure (5-10): Radon-222 distribution with the depth in the main stations

Figure (5-10) showed that the radon-222 concentrated at the upper $20 \mathrm{~m}$ of the Dead Sea. The highest concentrations were at a depth of $12 \mathrm{~m}$ in Sweimah, Zara and Mujeb areas, while the highest concentration was at a depth of $7 \mathrm{~m}$ in Zarka Ma'in area. This means that there is groundwater discharged into the Dead Sea from the upper $20 \mathrm{~m}$ with maximum rates at a depth of $12 \mathrm{~m}$ below surface.

These findings coincide with the findings from the EC-T results for the four stations along the Dead Sea as shown in figures (5-11) to (5-14). 


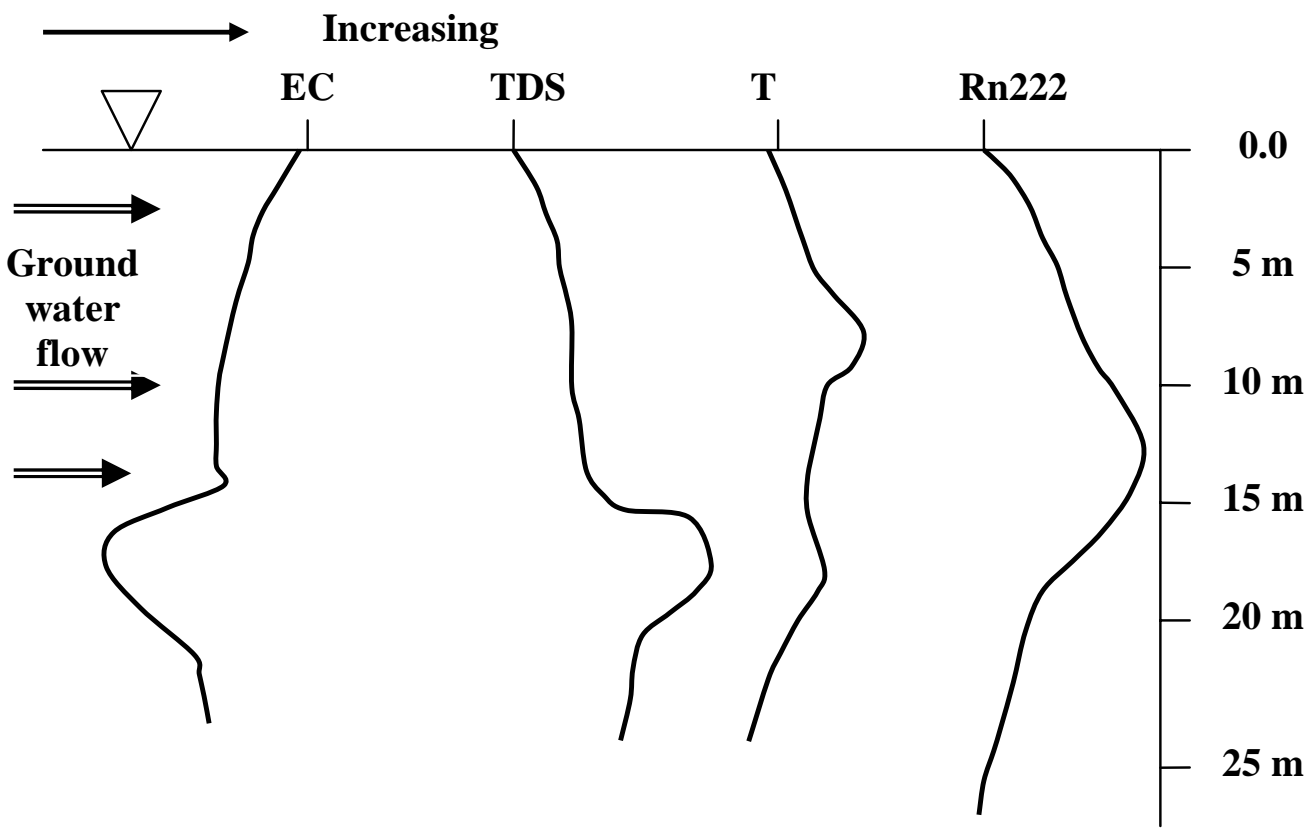

Figure (5-11): Schematic diagrams for EC, TDS, T and Rn222 showing the groundwater flow zone in Sweimah area.

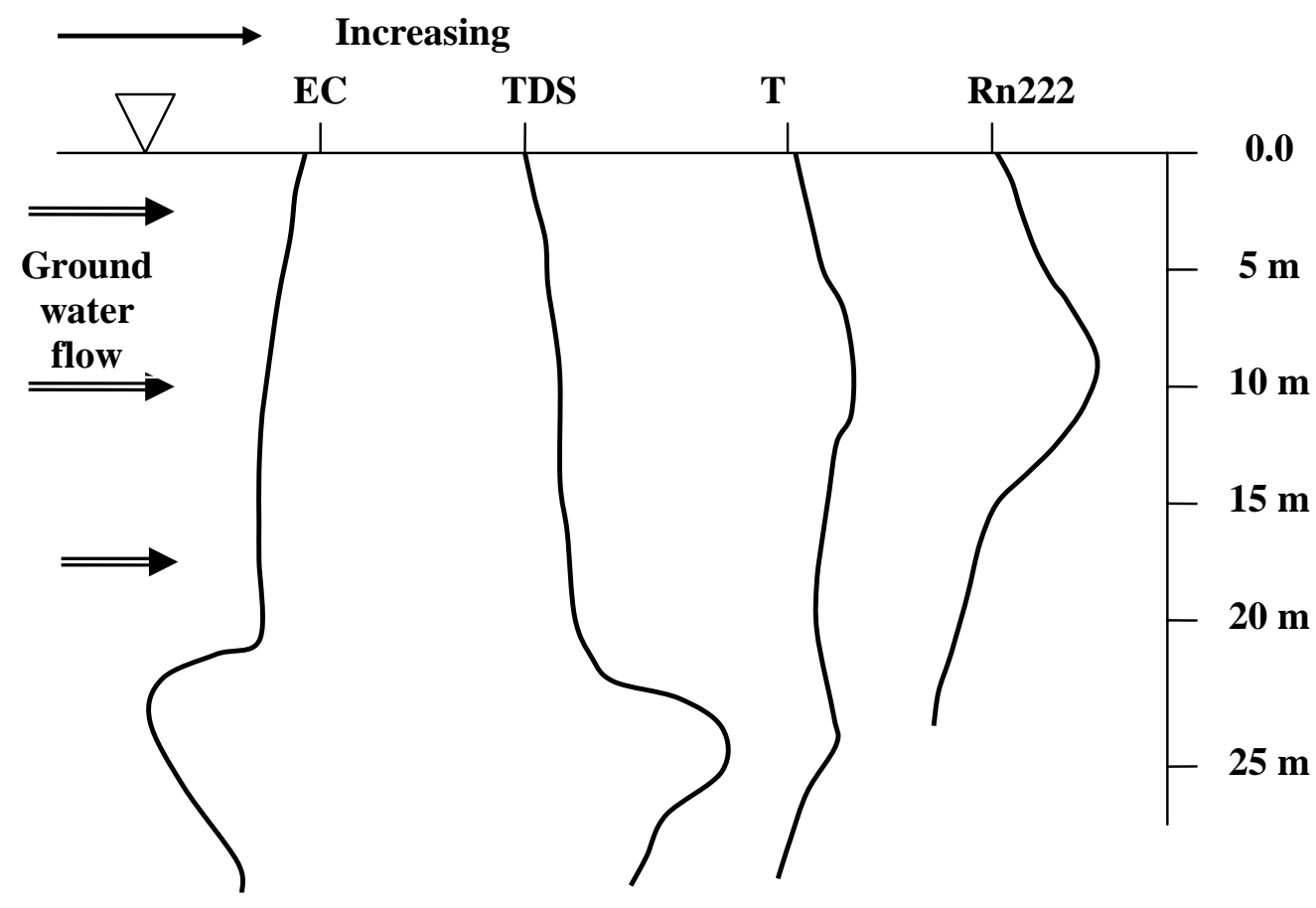

Figure ( 5-12): Schematic diagrams for EC, TDS, T and Rn222 showing the groundwater flow zone in Zarka Ma'in area. 


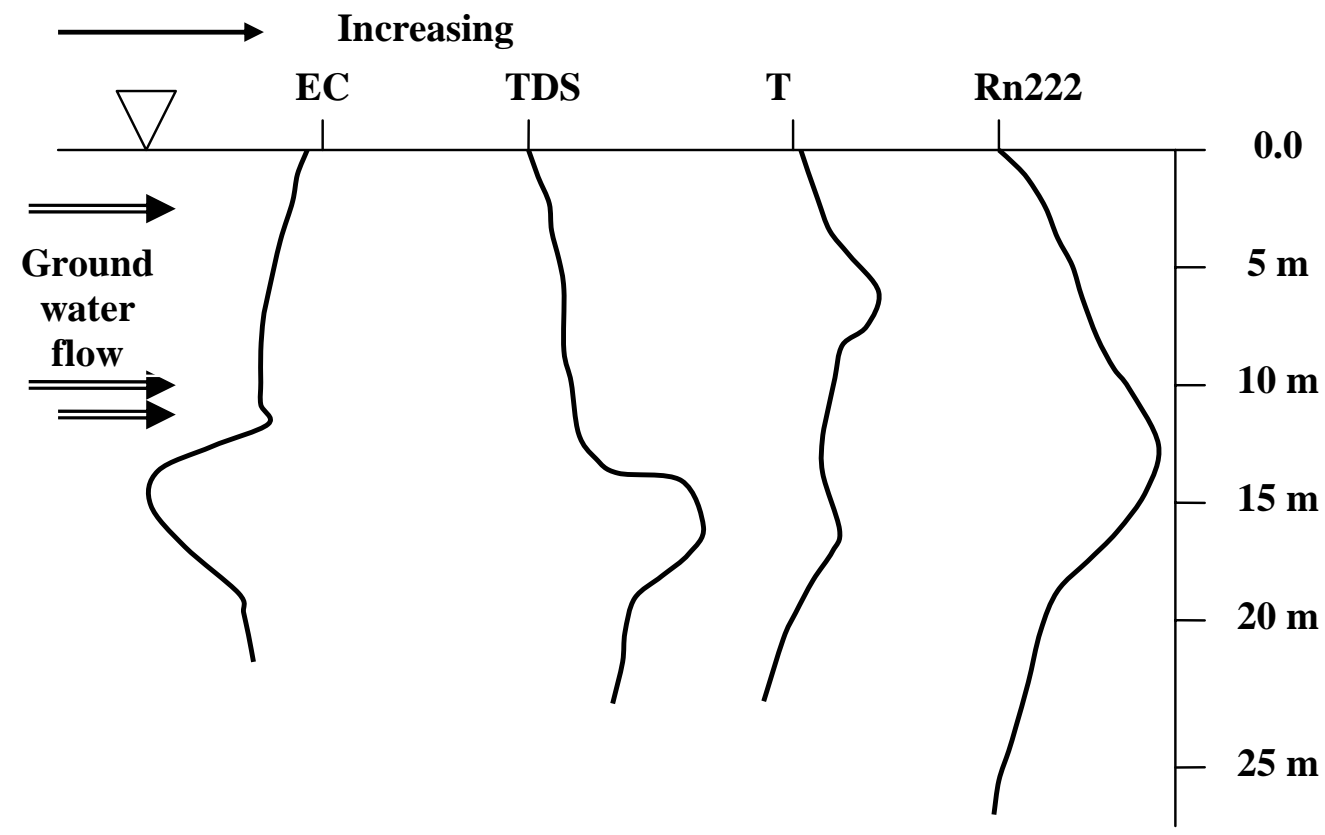

Figure (5-13): Schematic diagrams for EC, TDS, T and Rn222 showing the groundwater flow zone in Zara area.

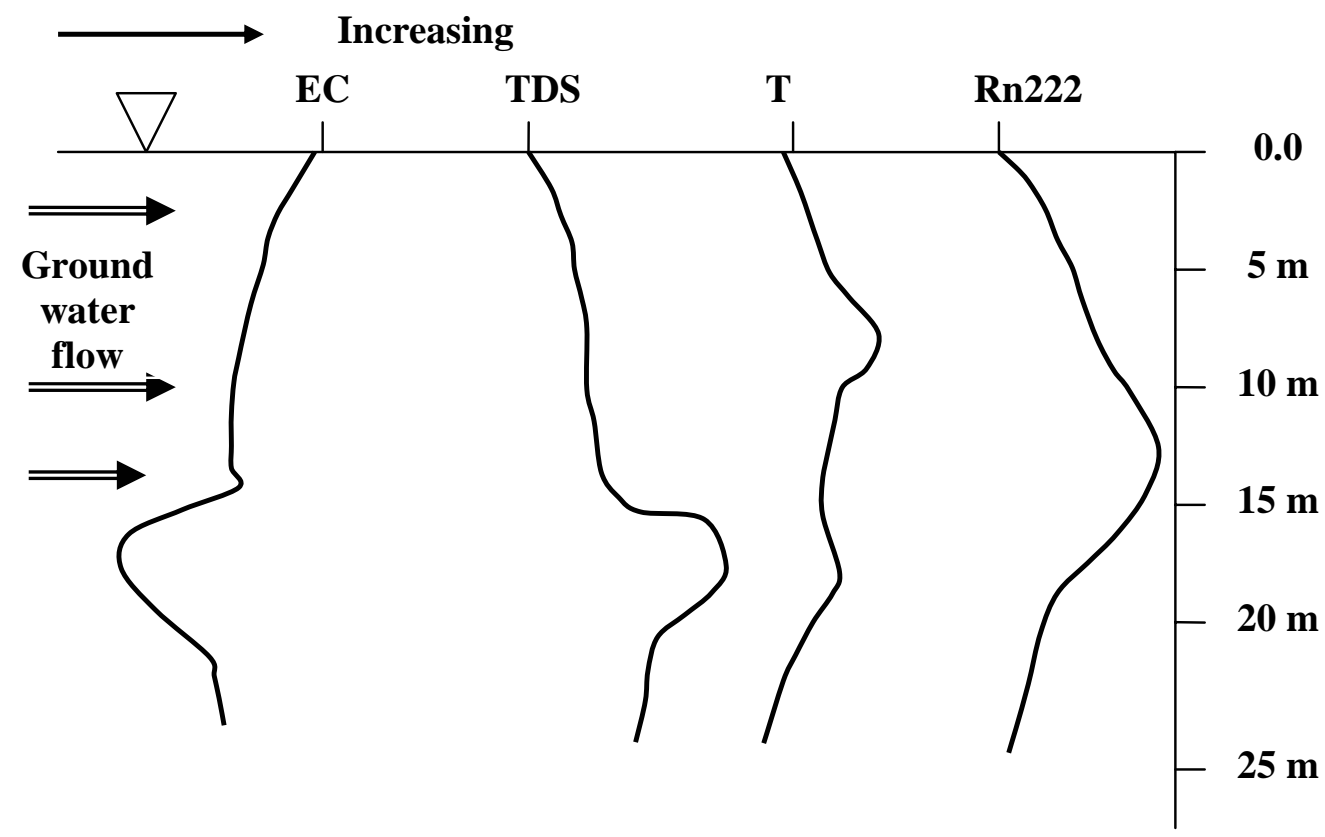

Figure (5-14): Schematic diagrams for EC, TDS, T and Rn222 showing the groundwater flow zone in Mujeb area. 
The distributions of radon concentrations with the distance parallel to the shorte and with the depth were plotted using surfer (Fig. 5-15). This figure shows that highly concentrations are found in Station2 in Zarka Ma'in area and moderate concentrations in station3 in Zara and station1 in Sweimah area. The lowest concentrations are found in station 4 in Mujeb, which might be the area with lowest groundwater discharge. The highest concentrations were found at a depth $12 \mathrm{~m}$. Generally the maximum ${ }^{222} \mathrm{Rn}$ concentrations of the seawater were found close to the shoreline and it decreasing with increasing the distances away from the shoreline. This means that the maximum groundwater flow might be closed to the shores of the Dead Sea.

Rn distributions at different depths

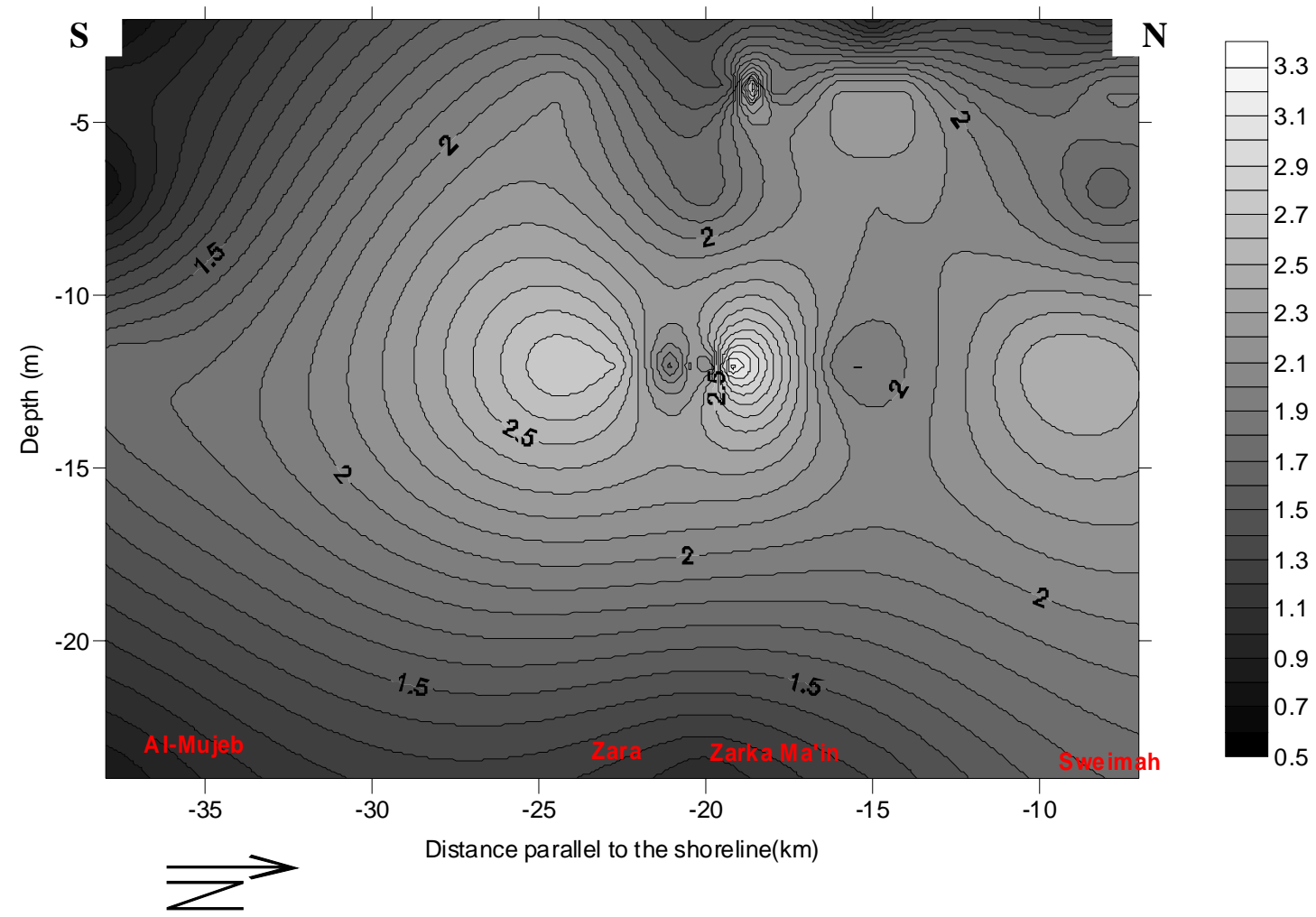

Figure (5-15): Radon-222 concentrations with the depth and distance N-S direction

The following general equation was used to calculate the radon budget:

$J_{\text {benthic }}+J_{\text {production }}-J_{\text {atm }}-J_{\text {decay }}-J_{\text {outllow }}=0$ 
$J_{\text {benthic }}$ : Flux of radon across the sediment-water interface consisting of a diffusion component of $\mathrm{Rn}$ from bottom sediments into overlying lake water $\left(\mathrm{J}_{\text {diffusion }}\right)$ and an advective component of Rn-rich groundwater through sediments $\left(J_{\text {advective }}\right)$, $J_{\text {production }}$ is the production of ${ }^{222} \mathrm{Rn}$ in the water column by $\mathrm{Ra}^{226}$ decay, $\mathrm{Jatm}$ is the ${ }^{222} \mathrm{Rn}$ loss across the air-water interface, $J_{\text {decay }}$ is the ${ }^{222} \mathrm{Rn}$ decay in the water column, $\mathrm{J}_{\text {outtlow }}$ is surface outflow of ${ }^{222} \mathrm{Rn}$-rich water from the sea.

The approach was to assess all flux terms to estimate the total benthic flux required to support the ${ }^{222} \mathrm{Rn}$ inventory

$J_{\text {benethic }}=J_{\text {atm }}+J_{\text {decay }}+J_{\text {outflow }}-J_{\text {production }}$

Equation (2) has been simplified to equation (3) because there is no outflow from the Dead Sea.

$J_{\text {benethic }}=J_{\text {atm }}+J_{\text {decay }}-J_{\text {production }}$

If the total benthic flux exceeds the independently estimated diffusive flux from the bottom sediments, then the advective component can be calculated by the following equation.

$J_{\text {advective }}=J_{\text {benethic }}-J_{\text {diffussion }}$

\subsubsection{Radon Inventory and Radon Decay}

Radon inventory is defined as the radon concentration at the water column gradient with the water depth column. After determining the concentration of ${ }^{222} \mathrm{Rn}$ the inventory was calculated by integrating the total radon concentrations over water depth.

$\mathrm{C}_{\mathrm{Rn}}(\mathrm{I})\left(\mathrm{Bq} \cdot \mathrm{m}^{-2}\right)=$ total $^{222} \mathrm{Rn}\left(\mathrm{Bq} \cdot \mathrm{m}^{-3}\right)$ * water depth $(\mathrm{m})$

$\mathrm{C}_{\mathrm{Rn}}$ is the radon inventory. The total radon is the concentration of supported and unsupported ${ }^{222} \mathrm{Rn}$.

${ }^{222} \mathrm{Rn}$ inventories were calculated for each station separately follows:

The total radon-222 concentration at specific depth was multiplied by the difference of the depth between two succession samples. After that the results of each station were added to get the total inventory for the all samples for each station.

- The total inventory At station1 $\left(\mathrm{S}_{\mathrm{rn} 1}\right)$ was

$1200\left(\mathrm{~Bq} \cdot \mathrm{m}^{-3}\right) * 2 \mathrm{~m}$ (the difference of the depths between of this sample and the depth of the next sample $)=2400\left(\right.$ Bq. $\left.\mathrm{m}^{-2}\right)$ 
$1900\left(\text { Bq. } m^{-3}\right)^{*} 4 \mathrm{~m}=5700\left(\right.$ Bq. $\left.\mathrm{m}^{-2}\right)$

$1600\left(\right.$ Bq. $\left.\mathrm{m}^{-3}\right) * 5 \mathrm{~m}=8000\left(\right.$ Bq. $\left.\mathrm{m}^{-2}\right)$

$2500\left(\right.$ Bq. $\left.\mathrm{m}^{-3}\right) * 12 \mathrm{~m}=30,000\left(\right.$ Bq. $\left.\mathrm{m}^{-2}\right)$

$1700\left(\right.$ Bq. $\left.\mathrm{m}^{-3}\right) * 2 \mathrm{~m}$ (The difference between the final depth $-26 \mathrm{~m}$ - and the depth of the sample $-24 \mathrm{~m}-)=3400\left(\right.$ Bq. $\left.\mathrm{m}^{-2}\right)$.

The total inventory for the first station was $49,500\left(\mathrm{~Bq} \cdot \mathrm{m}^{-2}\right)$ (i.e. the total of the above values).

- The total inventory at station $2\left(\mathrm{~S}_{\mathrm{nn} 2}\right)$ was calculated as that in the first station and it was $61,100\left(\right.$ Bq. $\left.\mathrm{m}^{-2}\right)$.

- The total inventory at station $3\left(\mathrm{~S}_{\mathrm{rn} 3}\right)$ was calculated as $39,200\left(\mathrm{~Bq} \cdot \mathrm{m}^{-2}\right)$.

- The total inventory at station $4(\mathrm{Srn} 4)$ was calculated as $30,900\left(\mathrm{~Bq} \cdot \mathrm{m}^{-2}\right)$.

The Decay of ${ }^{222} \mathrm{Rn}$ not supported by the decay of ${ }^{226} \mathrm{Ra}$ in the water column is the most important term and must be considered in the ${ }^{222} \mathrm{Rn}$ balance. This term can be calculated by using the radon inventory for the whole water column multiplyed by the ${ }^{222} \mathrm{Rn}$ decay constant $(\lambda)$ (expressed in day ${ }^{-1}$ which is equal 0.181 day $^{-1}$ ) according to the following equation:

$\mathrm{J}_{\text {decay }}=\lambda \mathrm{C}_{\mathrm{Rn}}$

Then the decay of radon-222 in the station $1\left(\mathrm{~S}_{\mathrm{rn} 1}\right)$ was calculated as follows:

$\mathrm{J}_{\text {decay }}=0.181 * 49,500=8959.5 \mathrm{~Bq} / \mathrm{m}^{-2}$.day

The decay in station 2 was calculated in the same way and gave $11059.1 \mathrm{~Bq} / \mathrm{m}^{-}$ 2.day

The decay in station $3\left(\mathrm{~S}_{\mathrm{rn} 3}\right)$ was $7095.2 \mathrm{~Bq} / \mathrm{m}^{-2}$.day. Finally the decay in station 4 $\left(\mathrm{S}_{\mathrm{rn} 4}\right)$ was calculated as $5592.9 \mathrm{~Bq} / \mathrm{m}^{-2}$.day.

\subsubsection{Radon Loss to the Atmosphere}

One of the important loss terms especially in shallow water is loss to the atmosphere. Radon losses by atmospheric evasion were calculated for each measurements station. The radon gas flux across air-water interface depends on the molecular diffusion produced by the concentration gradient across this interface and turbulent transfer governed primarily by wind speed above the sea surface. 
The gas exchange equations presented by Macintyre et al. (1995) were used to calculate the flux $\left(\mathrm{J}_{\mathrm{atm}}\right)$ of radon across sea-air interface using the radon concentration gradient, the surface water temperature, and the wind speed above the sea surface.

$J_{\mathrm{atm}}=\mathrm{k}\left(\mathrm{C}_{\mathrm{w}}-\alpha \mathrm{C}_{\mathrm{atm}}\right)$

Where $\mathrm{C}_{\mathrm{w}}$ and $\mathrm{C}_{\text {atm }}$ are the concentration of the gas of inters in surface water and Air respectively and the units are $\left(B q \cdot \mathrm{m}^{-3}\right) ; \alpha$ is Ostwald's solubility coefficient which deafens the distribution of radon between the water and air phases (dimensionless); and $\mathrm{k}$ is the gas transfer coefficient dependent on the wind speed (Jahne et al. 1987, Maclntyre et al. 1995 and Corbett et al. 1997). It is a function of the physical processes at the air-sea boundary, especially the turbulence and kinematics viscosity of the water $(\mathrm{v})$, and the Molecular diffusion coefficient of the gas $D_{m}$, where $D_{m}=1.7317{ }^{*} 10^{-5} \mathrm{~cm}^{2} \cdot \mathrm{s}^{-1}$ at $36^{\circ} \mathrm{C}$ for the radon. The Schmidt number (Sc) is the ratio of the kinematics viscosity to the molecular diffusion coefficient.

$\mathrm{Sc}=v / D_{\mathrm{m}}$ (dimensionless)

$\left.D_{m}=10^{(-((980 /(273+T))}+1,59\right)$.

$\mathrm{K}=\left(\left(0.45^{*}(\text { wind speed })^{1.6 *}\left((\mathrm{Sc} / 600)^{-0.667}\right)\right) / 100\right) / 60$

$\left.\alpha=0.105+0.405 e^{(-0.05027 *} \mathrm{T}\right)$.

Both wind speed and temperature are very important in controlling the loss of radon across the sea surface while the concentration of radon in the air has less importance, especially when the radon activity in the water is relatively high at the wind speed above $5 \mathrm{~m} . \mathrm{s}^{-1}$, while it is much less important when the wind speed under 2 m.s. ${ }^{-1}$ (Burnett et al. 2003).

The radon in atmosphere was estimated as $7 \mathrm{~Bq} / \mathrm{m}^{-3}$, the radon concentration at the surface was considered as the radon concentration at $2 \mathrm{~m}$ depth for all the stations. The wind speed was taken as $3 \mathrm{~m} / \mathrm{s}$. water temperature was measured between 36 and $38^{\circ} \mathrm{C}$.

The radon loss to the atmosphere at the station1 $\left(\mathrm{S}_{\mathrm{rn} 1}\right)$ was calculated by using equation 7 above:

$\mathrm{J}_{\text {atm }}=0.000519 \mathrm{~m} / \mathrm{min}\left(1200 \mathrm{~Bq} / \mathrm{m}^{-3}-0.17129849 * 7 \mathrm{~Bq} / \mathrm{m}^{-3}\right)=0.66217$ $\mathrm{Bq} / \mathrm{m}^{2} \cdot \min$

This value was multiplied by $(60 * 24)$ to transfer to unit of $\mathrm{Bq} / \mathrm{m}^{2}$.day. Then the radon loss to the surrounding atmosphere in station 1 was $895 \mathrm{~Bq} / \mathrm{m}^{2}$.day. 
The same calculations were made for the other thee stations and the radon loss to atmosphere results were as the following:

The loss to atmosphere in station $2\left(\mathrm{~S}_{\mathrm{rn} 2}\right)$ was $692.73 \mathrm{~Bq} / \mathrm{m}^{2}$.day. While in station 3 $\left(\mathrm{S}_{\mathrm{rn} 3}\right)$ the result was $1001 \mathrm{~Bq} / \mathrm{m}^{2}$.day and in station $4\left(\mathrm{~S}_{\mathrm{rn} 4}\right)$ the radon loss to the surrounding atmosphere was $596.69 \mathrm{~Bq} / \mathrm{m}^{2}$.day.

\subsubsection{Radon Input via Diffusion from the Sediments}

All sediments contain some amounts of uranium and daughter products including radon. Thus diffusion of ${ }^{222} \mathrm{Rn}$ from the bottom sediments into the overlying seawater may be it provides some unsupported radon into standing bodies of water and must be evaluated as part of an overall radon budget. These diffusive

${ }^{222} \mathrm{Rn}$ fluxes were obtained using a sediment equilibration technique, and radon flux was estimated using the following equation, which developed by (Martens et al. 1980).

$J_{\text {sedm }}=\left(\lambda D_{s}\right)^{1 / 2}\left(C_{\text {eq }}-C_{0}\right)$

$D_{s}$ are the effective wet bulk sediments diffusion coefficient in the sediments $\left(\mathrm{m}^{2}\right.$ day $^{-1}$ ) corrected for temperature and sediment tortuosity.

$\mathrm{C}_{\text {eq }}$ is the radon concentration in pore fluids in equilibrium with radium in the sediments, determined by the sediment equilibration experiments $\left(B q \cdot \mathrm{m}^{-3}\right) . \mathrm{C}_{0}$ is the radon concentration in the overlying water at the sediment-water interface. Ds is a wet sediment diffusion coefficient ( $\mathrm{m}^{2} /$ day).

$D_{s}=\Phi D_{0}($ Ullman and Aller 1981).

The expression for the temperature dependency of $D_{s}$ is outlined in Peng et al. (1974). The ${ }^{222} \mathrm{Rn}$ molecular diffusivity coefficient $\left(D_{0}\right)$ is $14.2^{*} 10^{-5} \mathrm{~m}^{2} /$ day at $36^{\circ} \mathrm{C}$. Then to get the wet bulk sediments diffusion coefficient $\left(D_{s}\right)$ this value was multiplied by the porosity of each soil. It equals $3.98 * 10^{-5} \mathrm{~m}^{2} /$ day at station 1 , where the porosity was $0.45-0.48$

The $\mathrm{C}_{\text {eq }}$ at the station1 was $0.0016 \mathrm{~Bq} / \mathrm{g}$, the bulk density of the soil was 2.07 $\mathrm{g} / \mathrm{cm}^{-3}$ then the $C_{\text {eq }}$ for wet sediment was $\left(0.0016^{\star} 2.07\right)=0.003312 \mathrm{~Bq} / \mathrm{cm}^{3}$ which is equal to $3312 \mathrm{~Bq} / \mathrm{m}^{3}$. Radon-222 concentration was $1700 \mathrm{~Bq} / \mathrm{m} 3$ at the bottom sediments. The porosity of the sediments was $0.45-0.48$. Then the $\mathrm{C}_{0}$ was obtained by multiplying the radon concentration at the bottom sediments by the porosity. $\mathrm{C}_{0}$ was equal to $476 \mathrm{~Bq} / \mathrm{m}^{3}$ at station1.

The radon input via sediments at the station $1\left(\mathrm{~S}_{\mathrm{rn} 1}\right)$ was calculated as the following 
$\mathrm{J}_{\text {sedm }}=\left(0.181^{*} 3.98 * 10^{-5}\right)^{1 / 2}(3312-476) \quad=7.61 \mathrm{~Bq} / \mathrm{m}^{2}$.day in station1 $\left(\mathrm{S}_{\mathrm{rn} 1}\right)$. The diffusion via sediments at the station2 $\left(\mathrm{S}_{\mathrm{rn} 2}\right)$ was $7.74 \mathrm{~Bq} / \mathrm{m}^{2}$.day, at station 3 $\left(\mathrm{S}_{\mathrm{rn} 3}\right)$ it was $7.81 \mathrm{~m}^{2}$.day and at station4 $\left(\mathrm{S}_{\mathrm{rn} 4}\right)$ was $5.73 \mathrm{~Bq} / \mathrm{m}^{2}$.day.

\subsubsection{Radon Production}

The additional inputs to the seawater are the Ingrowths (production) from $\mathrm{Ra}^{226}$ dissolved in the water column, which can be estimated by using the following equation:

$\mathrm{J}$ production $=\mathrm{C}_{\mathrm{Ra}}{ }^{*} \mathrm{~h}{ }^{*} \lambda$

$\mathrm{C}_{\mathrm{Ra}}$ represents the average concentration of ${ }^{226} \mathrm{Ra}$ in the Dead Sea; $\mathrm{h}$ is the depth of the Dead Sea layer under investigation.

$\mathrm{C}_{\mathrm{Ra}}$ was measured for some samples. Some samples were analyzed for radon activity, sealed for approximately 4 weeks, and then analyzed a second time for radon emanation. Radon emanation was considered to be equivalent to radium activity in these samples (Benoit et al. 1991). The depth was taken as $26 \mathrm{~m}$ for the investigated area, and $\lambda$ is equal as before $\left(0.181\right.$ day $\left.^{-1}\right)$. The average radon emanation was taken as the equivalent of ${ }^{226} \mathrm{Ra}$ at equilibrium with ${ }^{222} \mathrm{Rn}$ after 4 weeks storage. It was $1020 \mathrm{~Bq} \cdot \mathrm{m}^{-3}$ at the station $1\left(\mathrm{~S}_{\mathrm{rn} 1}\right)$, in tation $2\left(\mathrm{~S}_{\mathrm{rn} 2}\right)$ was 1050 Bq. $\mathrm{m}^{-3}$, it was 1040 Bq. $\mathrm{m}^{-3}$ in station3 $\left(\mathrm{S}_{\mathrm{rn} 3}\right)$ and it was $640 \mathrm{~Bq} \cdot \mathrm{m}^{-3}$ in station 4 $\left(\mathrm{S}_{\mathrm{rn} 4}\right)$.

Then the radon-222 production for the first station $\left(\mathrm{S}_{\mathrm{rn} 1}\right)$ was calculated by applying equation 9 above:

$J_{2}$ production $\left(\right.$ Bq. $m^{-2} \cdot$ day $)=1020\left(\right.$ Bq. $\left.m^{3}\right) * 26(m) * 0.181\left(\right.$ day $\left.^{-1}\right)=4800.12$ Bq $\cdot \mathrm{m}^{-}$ 2 .day.

The radon productions from ${ }^{226} \mathrm{Ra}$ in the other stations were as follows:

At station2 $\left(\mathrm{S}_{\mathrm{rn} 2}\right)$ it was $4941.3 \mathrm{~Bq} \cdot \mathrm{m}^{-2}$.day, at station3 $\left(\mathrm{S}_{\mathrm{rn} 3}\right)$ was $4894.24 \mathrm{~Bq} \cdot \mathrm{m}^{-}$ ${ }^{2}$.day and at station4 $\left(\mathrm{S}_{\mathrm{rn} 4}\right)$ it was $3011.84 \mathrm{~Bq} \cdot \mathrm{m}^{-2}$. day

\subsubsection{Final Calculations}

The $J_{\text {benethic }}$ were calculated for all the stations by using equation (3) above as the following:

The $J_{\text {benethic }}$ for station $1\left(S_{\mathrm{rn} 1}\right)$ was 
$\mathrm{J}_{\text {benethic }}\left(\right.$ Bq. $\mathrm{m}^{-2} \cdot$ day $)=895.41\left(\right.$ Bq $\cdot \mathrm{m}^{-2} \cdot$ day $)+8959 \cdot 5\left(\right.$ Bq $\cdot \mathrm{m}^{-2} \cdot$ day $)-4800.12\left(\left(\mathrm{~Bq} \cdot \mathrm{m}^{-}\right.\right.$ ${ }^{2}$.day) $=5054.79\left(\right.$ Bq. $\mathrm{m}^{-2} \cdot$ day $)$.

Then to calculate the $J_{\text {advective }}$ for all stations equation (4) was used. The advection at station $1\left(\mathrm{~S}_{\mathrm{rn} 1}\right)$ was:

$\mathrm{J}_{\text {advective }}\left(\right.$ Bq $\cdot \mathrm{m}^{-2} \cdot$ day $)=5054.79\left(\right.$ Bq $\cdot \mathrm{m}^{-2} \cdot$ day $)-7 \cdot 61\left(\mathrm{~Bq} \cdot \mathrm{m}^{-2} \cdot\right.$ day $)=5046 \cdot 39\left(\mathrm{~Bq} \cdot \mathrm{m}^{-}\right.$ 2 .day).

The same calculations were done to the other stations. The $J_{\text {benethic }}$ for the station2 $\left(\mathrm{S}_{\mathrm{rn} 2}\right)$ was 6810.53 (Bq. $\mathrm{m}^{-2}$.day), and $\mathrm{J}_{\text {advective was }} 6802.79$ (Bq. $\mathrm{m}^{-2} \cdot$ day). The $\mathrm{J}_{\text {benethic }}$ at station3 $\left(\mathrm{S}_{\mathrm{rn} 3}\right)$ was $3107.84\left(\mathrm{~Bq} \cdot \mathrm{m}^{-2}\right.$.day) and $\mathrm{J}_{\text {advective }}$ was 3147.09 (Bq.m ${ }^{2}$.day). The $J_{\text {benethic }}$ at the station4 $\left(\mathrm{S}_{\mathrm{rn} 4}\right)$ was 3177.7 (Bq. $\mathrm{m}^{-2}$.day) and the $\mathrm{J}_{\text {advective }}$ was 3171.97 (Bq. $\mathrm{m}^{-2}$.day). All the results were summarized in the table (4-5).

Table (5-5): Radon-222 results of inventory, decay, advection, diffusion and production.

\begin{tabular}{|c|c|c|c|c|c|c|c|}
\hline $\begin{array}{l}\text { Station } \\
\text { name }\end{array}$ & $\begin{array}{l}{ }^{222} \mathrm{Rn} \\
\text { Inv. } \\
\left(\text { Bq. } \mathrm{m}^{-2}\right)\end{array}$ & $\begin{array}{l}J_{\text {decay }} \\
\left.\text { (Bq. } m^{-2} \cdot \text { day }\right)\end{array}$ & $\begin{array}{l}J_{\text {atmos }} \\
\left.\text { (Bq. } \text { m }^{-2} \cdot \text { day }\right)\end{array}$ & $\begin{array}{l}J_{\text {diffussion }} \\
\text { (Bq. } m^{-2} . \text { day) }\end{array}$ & $\begin{array}{l}\text { J production } \\
\left.\text { (Bq. } \mathrm{m}^{-2} . \text { day }\right)\end{array}$ & $\begin{array}{l}J_{\text {benethic }} \\
\text { (Bq. } m^{-2} \cdot \text { day) }\end{array}$ & $\begin{array}{l}\text { Jadvective } \\
\left.\text { (Bq. } \mathrm{m}^{-2} . \text { day }\right)\end{array}$ \\
\hline$S_{r n 1}$ & 49500 & 8959.5 & 895.41 & 7.61 & 4800.12 & 5054.79 & \begin{tabular}{|l|}
5046.39 \\
\end{tabular} \\
\hline $\mathrm{S}_{\mathrm{rn2}}$ & 61100 & 11059.1 & 692.73 & 7.74 & 4941.3 & 6810.53 & 6802.79 \\
\hline $\mathrm{S}_{\mathrm{rn3}}$ & 39200 & 7095.2 & 1001 & 7.81 & 4894.24 & 3107.84 & 3147.09 \\
\hline $\mathrm{S}_{\mathrm{rn} 4}$ & 30900 & 5592.9 & 596.64 & 5.73 & 3011.84 & 3177.7 & 3171.97 \\
\hline
\end{tabular}

\subsubsection{Radon Concentration in the Groundwater and Advection Rate}

${ }^{222} \mathrm{Rn}$ activities in the groundwater obtained from springs located around the Dead Sea shows a little variation. Activities ranged from $28100 \mathrm{~Bq} \cdot \mathrm{m}^{-3}$ to $69300 \mathrm{~Bq} \cdot \mathrm{m}^{-3}$ $\left(1368{ }^{*} 10^{3}\right.$ to $\left.4158{ }^{*} 10^{3} \mathrm{dpm} \cdot \mathrm{m}^{-3}\right)(\mathrm{n}=14)$. The maximum value in Sweimah area is 45900 Bq. $\mathrm{m}^{-3}$ the minimum value is $30100 \mathrm{~Bq} \cdot \mathrm{m}^{-3}$ and the range [(Maximum + minimum)/2] of the radon concentration in the groundwater in this area is 38000 Bq. $\mathrm{m}^{-3}$. In Zarka Ma'in area the maximum, minimum and range values were 51400 Bq. $\mathrm{m}^{-3}$. The maximum value of $\mathrm{Rn}-222$ activity in groundwater in Zara area is $62600 \mathrm{~Bq} \cdot \mathrm{m}^{-3}$, the minimum value is $32800 \mathrm{~Bq} \cdot \mathrm{m}^{-3}$ and the range is $47700 \mathrm{~Bq} \cdot \mathrm{m}^{-3}$. The maximum Rn-222 concentration in the groundwater in Mujeb area is 69300 Bq. $\mathrm{m}^{-3}$, the minimum value is $28100 \mathrm{~Bq} \cdot \mathrm{m}^{-3}$ and the range is $48700 \mathrm{~Bq} \cdot \mathrm{m}^{-3}$. Table (4-5) shows the ${ }^{222} \mathrm{Rn}$ concentrations and electrical conductivity for the springs and seepages surrounding the Dead Sea shores. 
Table (5-6): Radon-222 concentrations and EC in the springs and seepages surrounding the Dead Sea.

\begin{tabular}{|l|l|l|l|}
\hline Springs Name & $\begin{array}{l}\mathrm{Rn}-222 \\
\mathrm{~Bq} / \mathrm{l}\end{array}$ & $\begin{array}{l}\text { Station } \\
\text { No. }\end{array}$ & $\begin{array}{l}\mathrm{EC} \\
(\mathrm{mS} / \mathrm{cm})\end{array}$ \\
\hline $\begin{array}{l}\text { Seepage-DS } \\
\text { coast-N.Hotels }\end{array}$ & 33.4 & $\mathrm{~S}_{\mathrm{rn} 1}$ & 39 \\
\hline $\begin{array}{l}\text { Seepage-DS } \\
\text { coast-Hotels }\end{array}$ & 45.9 & $\mathrm{~S}_{\mathrm{rn} 1}$ & 22.1 \\
\hline Azrak-Sweimah & 30.6 & $\mathrm{~S}_{\mathrm{rn} 1}$ & 5.6 \\
\hline Hamdi Anis & 30.1 & $\mathrm{~S}_{\mathrm{rn} 1}$ & 6.1 \\
\hline Zarka Ma'in & 51.4 & $\mathrm{~S}_{\mathrm{rn} 2}$ & 2.7 \\
\hline $\begin{array}{l}\text { Zara- } \\
\text { Hotspring1 }\end{array}$ & 62.6 & $\mathrm{~S}_{\mathrm{rn} 3}$ & 2.5 \\
\hline $\begin{array}{l}\text { Zara- } \\
\text { Hotspring22 }\end{array}$ & 53.9 & $\mathrm{~S}_{\mathrm{rn} 3}$ & 2.2 \\
\hline $\begin{array}{l}\text { Zara- } \\
\text { Hotspring23 }\end{array}$ & 60.8 & $\mathrm{~S}_{\mathrm{rn} 3}$ & 2.4 \\
\hline $\begin{array}{l}\text { Zara- } \\
\text { Hotspring24 }\end{array}$ & 32.8 & $\mathrm{~S}_{\mathrm{rn} 3}$ & 2.54 \\
\hline $\begin{array}{l}\text { Seepage-DS } \\
\text { coast }\end{array}$ & 38.2 & $\mathrm{~S}_{\mathrm{rn} 3}$ & 4.2 \\
\hline $\begin{array}{l}\text { Homrt Main-DS } \\
\text { coast }\end{array}$ & 53.7 & $\mathrm{~S}_{\mathrm{rn} 4}$ & 4.8 \\
\hline $\begin{array}{l}\text { Ein Skeen1- } \\
\text { G.Mazra }\end{array}$ & 30.6 & $\mathrm{~S}_{\mathrm{rn} 4}$ & 1.3 \\
\hline $\begin{array}{l}\text { Ein Skeen2- } \\
\text { G.Mazra }\end{array}$ & 28.1 & $\mathrm{~S}_{\mathrm{rn} 4}$ & 1.1 \\
\hline $\begin{array}{l}\text { Al-Moruaha-G. } \\
\text { Hadithah }\end{array}$ & 69.3 & $\mathrm{~S}_{\mathrm{rn} 4}$ & 11.5 \\
\hline $\begin{array}{l}\text { Al-Haditha-G. } \\
\text { Haditha }\end{array}$ & 48.8 & $\mathrm{~S}_{\mathrm{rn} 4}$ & 0.9 \\
\hline
\end{tabular}

The advection rates for all the stations were calculated as dividing the advection (Jadvection) values, which calculated above over the range value of the radon-222 concentrations in the groundwater, where the advection rate is equivalent to the groundwater velocity. Then the total amount of the groundwater discharge (m3/day, year) is equal the advection rate multiplying by the area $\left(\mathrm{m}^{2}\right)$ of the discharge.

The advection rate in station1 $\left(\mathrm{S}_{\mathrm{rn} 1}\right)$ was $=5046.39\left(\mathrm{~Bq} / \mathrm{m}^{2} \cdot\right.$ day $) / 38000\left(\mathrm{~Bq} / \mathrm{m}^{3}\right)=$ $0.1328 \mathrm{~m} /$ day

The advection rate in station2 $\left(\mathrm{S}_{\mathrm{rn} 2}\right)$ was $=6802.79\left(\mathrm{~Bq} / \mathrm{m}^{2}\right.$.day $) / 51400\left(\mathrm{~Bq} / \mathrm{m}^{3}\right)=$ $0.1324 \mathrm{~m} /$ day 
The advection rate in station3 $\left(\mathrm{S}_{\mathrm{rn} 3}\right)$ was $=3147.09\left(\mathrm{~Bq} / \mathrm{m}^{2}\right.$.day $) / 47700\left(\mathrm{~Bq} / \mathrm{m}^{3}\right)=$ $0.066 \mathrm{~m} /$ day

The advection rate in station $4\left(\mathrm{~S}_{\mathrm{rn} 4}\right)$ was $=3171.97\left(\mathrm{~Bq} / \mathrm{m}^{2}\right.$. day $) / 48700\left(\mathrm{~Bq} / \mathrm{m}^{3}\right)=$ $0.0651 \mathrm{~m} / \mathrm{day}$

The areas of the groundwater discharges were estimated using the maps of the area and the thermal infrared images.

The area of groundwater discharge in Sweimah was estimated about 2,800,000 $\mathrm{m}^{2}$, the area of discharge in Zarka Ma'in area, in Zara area and in Mujeb are $2,660,000 \mathrm{~m}^{2}, 1,400,000 \mathrm{~m}^{2}$ and $2,000,000 \mathrm{~m}^{2}$ respectively.

Then the total amount of groundwater discharge into the Dead Sea in station1 was 135.7 MCM/y, in station2 was $128.5 \mathrm{MCM} / \mathrm{y}$, in station3 was equal 33.7 MCM/y and the amount of submarine groundwater discharge into the Dead Sea in station 4 was equal $90.3 \mathrm{MCM} / \mathrm{y}$.

Finally the total amount of the submarine groundwater discharge into the eastern shoreline of Dead Sea is equal the sum of the discharges in all stations which equals $388.3 \mathrm{MCM} / \mathrm{y}$. This value was compared with the amount of discharge was obtained from the water budget technique which was $480 \mathrm{MCM} / \mathrm{y}$ (million cubic meter per year). The difference is due to the amount of the discharge using the water budget was for the whole Dead Sea (the west and east sides) while the discharge estimated using radon technique was for the eastern shoreline.

\subsection{Estimating SGD by Using Mixing Technique for TDS}

To estimate the groundwater discharge into the Dead Sea the schematic sketch in figure (516) was considered.

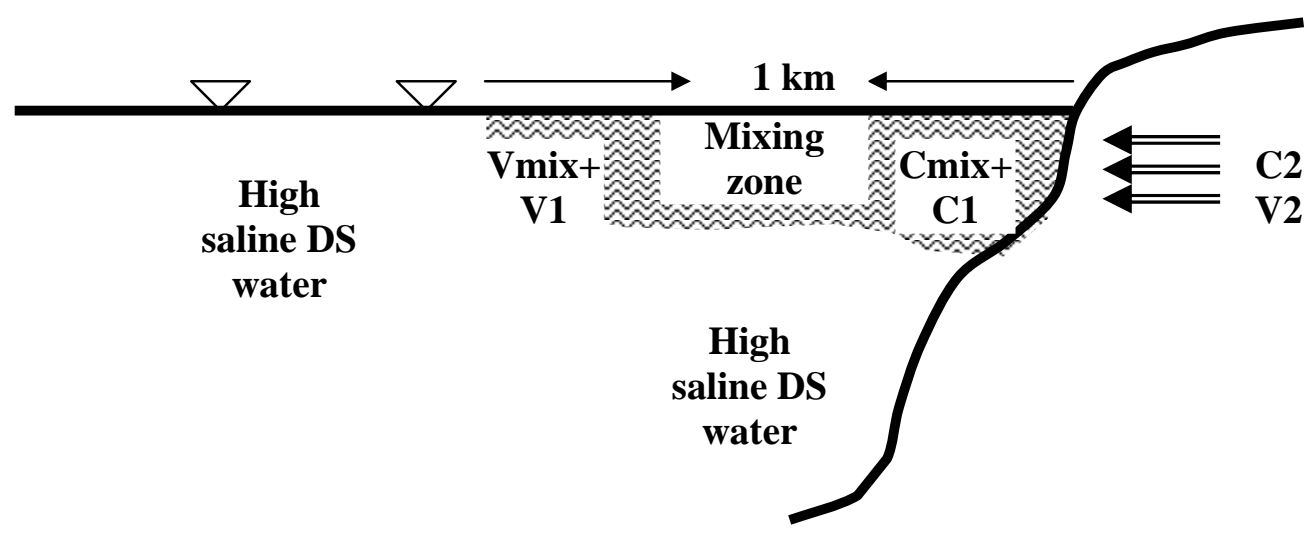

Figure (5-16): Schematic diagram of SGD and the mixing zones 
To estimate the submarine groundwater discharge into the DS by using mixing technique depends on the TDS the following equations were used:

$\mathrm{V} 1 * \mathrm{C} 1+\mathrm{V} 2 * \mathrm{C} 2=\mathrm{V}_{\text {mix }} * \mathrm{C}_{\text {mix }}$

$\mathrm{V} 1+\mathrm{V} 2=\mathrm{V}_{\text {mix }}$

Where the V1 is the volume of the DS water at the mixing zone, Vmix is the total volume of the mixing zone, $\mathrm{V} 2$ is the volume of the submarine groundwater discharging into the DS at the mixing zone, $\mathrm{C} 1$ is the TDS of the DS water before mixing, C2 is the TDS of the submarine groundwater and Cmix is the TDS of the DS water after mixing with submarine groundwater.

$\mathrm{V} 1=\mathrm{V}_{\text {mix }}-\mathrm{V} \mathbf{2}$

$($ Vmix - V2 $) \mathrm{C} 1+\mathrm{V} 2 * \mathrm{C} 2=\mathrm{Vmix} * \mathrm{Cmix}$

V2 $=[($ Vmix * Cmix $)-($ Vmix * C1) $] /(\mathrm{C} 2-\mathrm{C} 1)$

The quantity of the submarine groundwater discharging (V2) into the DS in Sweimah area is:

V2 $($ in Sweimah $)=[(112 \mathrm{MCM}$ * $293 \mathrm{~g} / \mathrm{l})-(112 \mathrm{MCM}$ * $405 \mathrm{~g} / \mathrm{l})] /(26 \mathrm{~g} / \mathrm{l}-405 \mathrm{~g} / \mathrm{l})$ $=33.1 \mathrm{MCM}$ for the period from last winter on march until the time of carrying out the measurements on July (4 months) then this quantity of submarine groundwater discharge into the DS in Sweimah area is $33.1 \mathrm{MCM} / 4$ months. Therefore the total amount of discharge into the DS in Sweimah area in the year is $33.1 \mathrm{MCM}$ times 3 which is equal $100 \mathrm{MCM} / \mathrm{y}$.

The submarine groundwater discharge into the DS (V2) in Zarka Ma'in and Zara area is:

V2 (in Zarka Ma'in and Zara) $=[(100 \mathrm{MCM}$ * $311 \mathrm{~g} / \mathrm{l})-(100 \mathrm{MCM}$ * $391 \mathrm{~g} / \mathrm{l})] /(18$ $\mathrm{g} / \mathrm{l}-391 \mathrm{~g} / \mathrm{l})=21.5 \mathrm{MCM} / 4$ months and the total quantity in the year is $21.5 \mathrm{MCM}$ times 3 which equals $65 \mathrm{MCM} / \mathrm{y}$

The discharge (V2) into the DS in Mujeb area is:

V2 (in Mujeb) $=\left[\left(90 \mathrm{MCM}^{*} 366 \mathrm{~g} / \mathrm{l}\right)-(90 * 388)\right] /(18 \mathrm{~g} / \mathrm{l}-388 \mathrm{~g} / \mathrm{l})=5.4 \mathrm{MCM} / 4$ months. Therefore the total discharge into the DS in Mujeb area in the year is 5.4 MCM times 3 which is equal $16.2 \mathrm{MCM} / \mathrm{y}$ 
Then the total submarine groundwater discharge into the DS is:

$100+65+16.2=181.2 \mathrm{MCM} / \mathrm{y}$.

\subsection{Estimating SGD by Using Darcy's Law.}

For estimating the groundwater discharge into the DS by using one-dimensional Darcy's law the following equation was used:

$Q=A * K *(\Delta h / L)$

Where,

$Q$ is volumetric flow rate $\left(\mathrm{m}^{3} / \mathrm{s}\right), A$ is flow area perpendicular to $L\left(\mathrm{~m}^{2}\right), K$ is hydraulic conductivity $(\mathrm{m} / \mathrm{s}), \mathrm{L}$ is flow path length $(\mathrm{m})$ and $\mathrm{h}$ is hydraulic head $(\mathrm{m})$.

The average area of discharge was estimated as:

A $=55000 \mathrm{~m}^{*} 18 \mathrm{~m}=990000 \mathrm{~m}$

$\mathrm{K}=4.48 * 10^{-5} \mathrm{~m} / \mathrm{s}$ (Salameh and Udluft, 1985)

$\Delta \mathrm{h} / \mathrm{L}=0.04$ (Salameh and Udluft, 1985)

$\mathrm{Q}=990000 * 4.48 * 10^{-5} * 0.04=1.8 \mathrm{~m} / \mathrm{s}$ (which equals $\left.57 \mathrm{MCM} / \mathrm{y}\right)$.

The quantities of the groundwater discharge estimating from radon222, mixing of TDS, and Darcy's' law in addition to water balance are listed in table 5-7 
Table (5-7): The quantities of groundwater discharge estimating from the different methods

\begin{tabular}{|c|c|l|}
\hline Method & $\begin{array}{l}\text { Discharge } \\
\text { (MCM/y) }\end{array}$ & Errors \\
\hline Rn222 & 388 & $\begin{array}{l}\text { In measurements, in internal } \\
\text { humidity of the RAD7 device, very } \\
\text { low errors due to water density, }\end{array}$ \\
\hline Mixing & 181 & $\begin{array}{l}\text { Don't consider the horizontal } \\
\text { mixing along the DS, don't } \\
\text { consider the volume of dissolved } \\
\text { salt from the salt layer at the coast. }\end{array}$ \\
\hline Darcy & 57 & $\begin{array}{l}\text { Don't consider the circulation, } \\
\text { estimated as a steady state and } \\
\text { homogeneity formation along the } \\
\text { DS, lack of the information for the } \\
\text { hydraulic conductivity and } \\
\text { hydraulic gradient for lower aquifer } \\
\text { in east of the DS area and no data } \\
\text { for them at the distance less than 5 } \\
\text { km to the east of the coast of the } \\
\text { DS, }\end{array}$ \\
\hline Water balance & 480 & $\begin{array}{l}\text { Calculated for the whole DS (i.e. } \\
\text { east and west shores), evaporation } \\
\text { estimation, don't consider the } \\
\text { water circulation. }\end{array}$ \\
\hline & &
\end{tabular}

The above results of the estimation of the SGD showed that the SGD might be between 200 and $300 \mathrm{MCM} / \mathrm{y}$.

\subsection{Thermal Infrared Imagery (TIR)}

Field conditions for the imagery survey were ideal and the resolution of thermal signatures from upwelling groundwater was clear. The results of the thermal imagery survey indicate that there are groundwater discharge zones into the Dead Sea. These zones are characterized by high temperature compared to other zones where no discharges occur. In wintertime the temperature of the groundwater in the Dead Sea surrounding areas is higher than that of the surface water of the Dea Sea itself.

Figure (5-17) illustrates groundwater discharge zones in the areas of Zarka Ma'in, Zara and Mujeb and the coordinates for these zones. The thermal infrared images show that the highest groundwater discharges are found close to the Dead Sea 
shorelines. These results are match well with the results obtained from the radon222 technique. The images show also that the zones of the discharges in Zara, Zarka Ma'in and Mujeb areas are match with the results obtained by using the electromagnetic radiation technique (EMR) (section 5.4).

The main discharge zone obtained from the thermal infrared images in Zarka Ma'in area has coordinates $31.61080324 \mathrm{~N}$ and $35.56301848 \mathrm{E}$ (Decimal coordinate), the other main zone in the same area has coordinate $31.59574664 \mathrm{~N}$ and $35.55765117 \mathrm{E}$. On the other hand the main discharge zones in Zara area lie between coordinates of $31.57230500 \mathrm{~N}, 35.55385840 \mathrm{E}$ and $31.57050383 \mathrm{~N}$, $35.55395937 \mathrm{E}$, while in Mujeb area it lie at $31.46635725 \mathrm{~N}$ and $35.56297085 \mathrm{E}$.

Some discharge zones and the coordinates are listed in table (5-8).

Table (5-8): Coordinates of some of the discharge zones along the eastern shoreline of the Dead Sea.

\begin{tabular}{|l|l|l|l|l|}
\hline Area name & \multicolumn{3}{|l|}{$\begin{array}{l}\text { Coordinate } \\
\text { (Geographic decimal) }\end{array}$} & \multicolumn{2}{l|}{ Coordinate } \\
\cline { 2 - 5 } & $\mathrm{N}$ & $\mathrm{E}$ & $\mathrm{N}$ & $\mathrm{E}$ \\
\hline Zarka Ma'in & 31.60044167 & 35.56063333 & 31.59574664 & 35.55765117 \\
\cline { 2 - 5 } & 31.61080324 & 35.56301848 & 31.59305540 & 35.55727731 \\
\hline Zara & 31.57615524 & 35.55411354 & 31.57230500 & 35.55385840 \\
\cline { 2 - 5 } & 31.57050383 & 35.55395937 & 31.56883709 & 35.55376381 \\
\cline { 2 - 5 } & 31.56421919 & 35.55333771 & 31.56344255 & 35.55361671 \\
\cline { 2 - 6 } & 31.56073928 & 35.55384319 & 31.55958030 & 35.55396167 \\
\cline { 2 - 6 } & 31.54414031 & 35.55489140 & & \\
\hline Mujeb & 31.46635725 & 35.56297085 & 31.45092313 & 35.56359963 \\
\hline
\end{tabular}




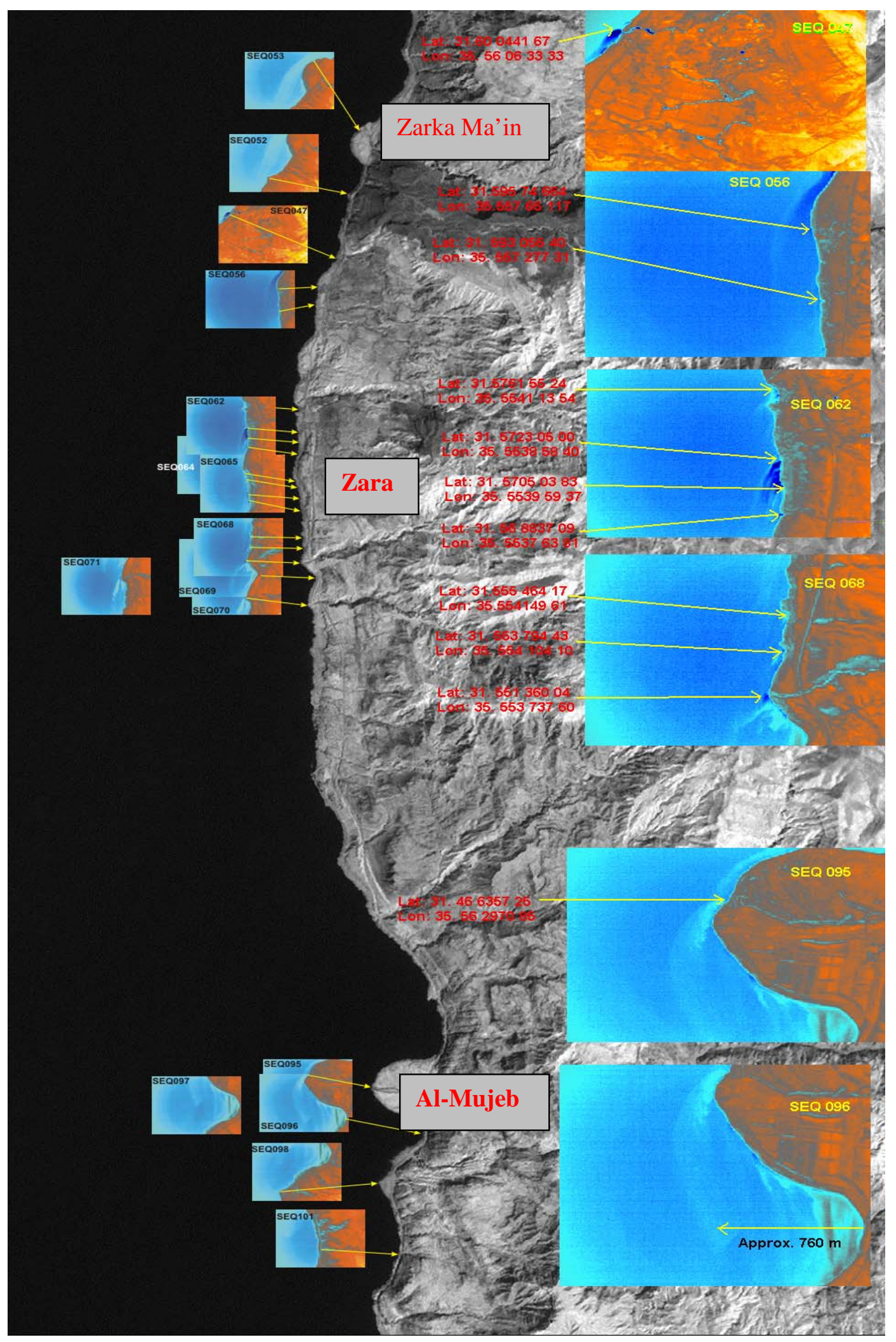

Figure (5-17): Discharges zones along the DS coast obtained by using TIR. 
The dark blue color on the temperature scale indicates at a mixed groundwater flows to the Dead Sea. The light blue color on the temperature scale indicates at the Dead Sea water temperature without any mixing with groundwater. In Zara area the blue color is much darker than that in Mujeb area because the temperature of the groundwater (Thermal) in Zara area is warmer than that of Mujeb area (Fig. 5-18).
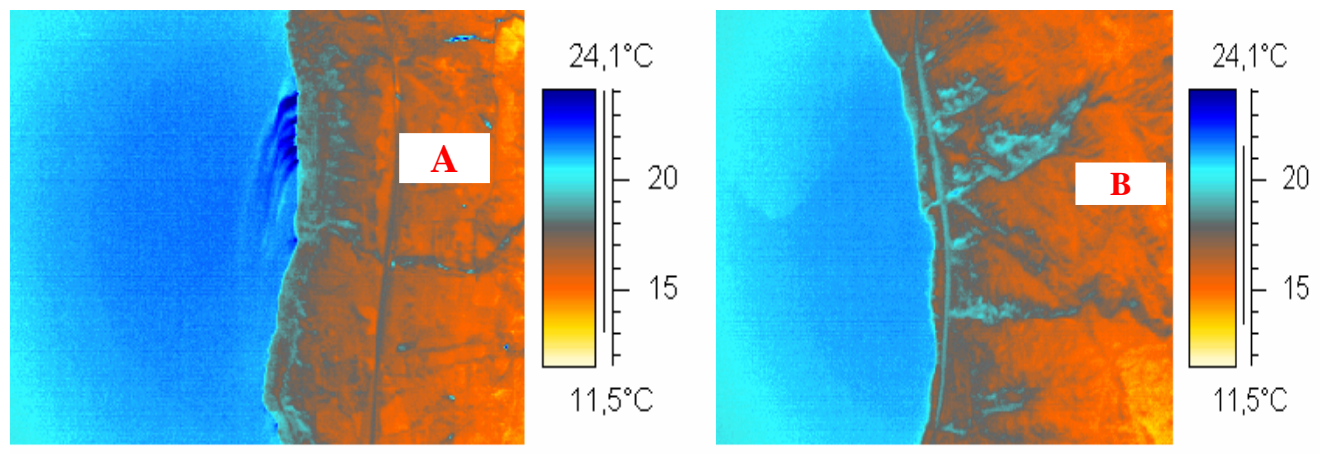

Figure (5- 18): TIR imagery with T scale in Zara (A) and in Mujeb (B).

The thermal infrared images show that the distribution of the groundwater discharges are concentrated at the shoreline and distributed to about between 360 $\mathrm{m}$ and more than $750 \mathrm{~m}$ away from the shoreline (Fig. 5-19 A-C). These results coincide with the results obtained from the electrical conductivity measurements (last section). Some springs were also indicated and their location difined by using thermal infrared images (Fig. 5-19).

(A) Zarka Ma'in area

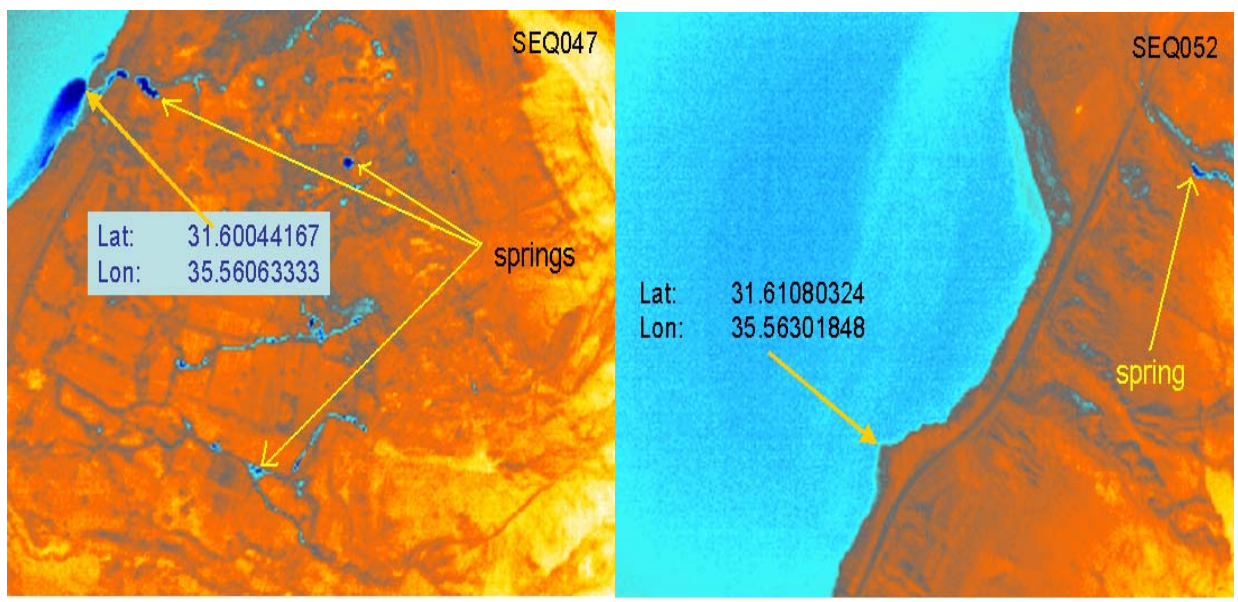



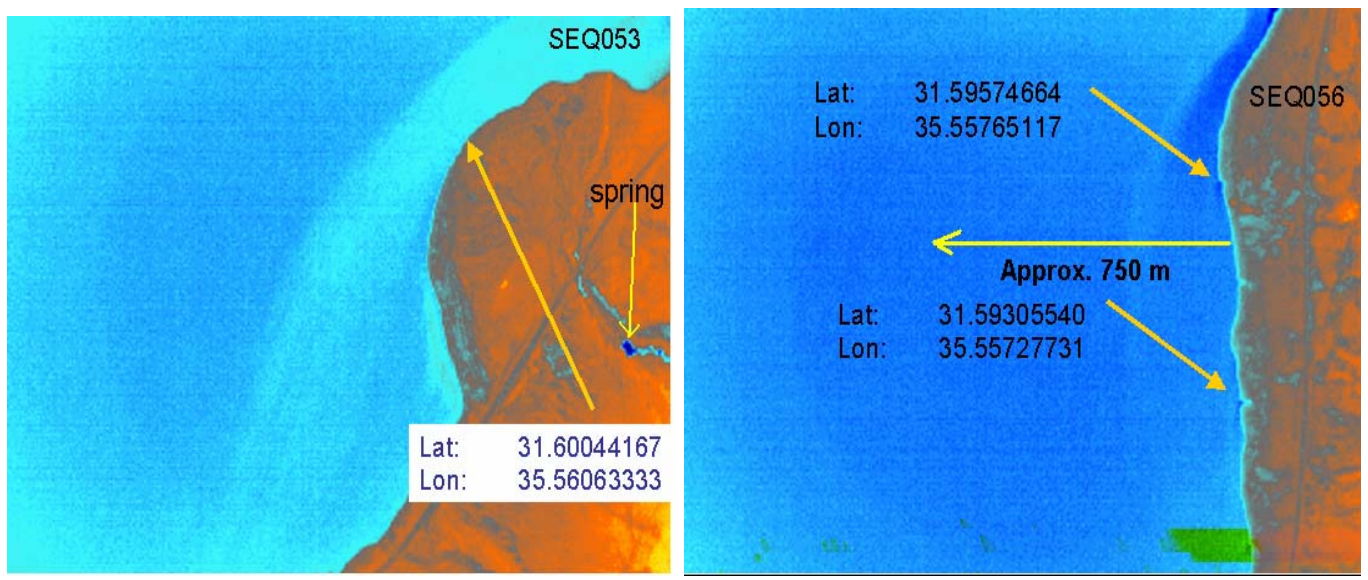

Figure (5-19 A): Groundwater flow distribution in Zarka Ma'in indicated by TIR images.

(B) Zara area
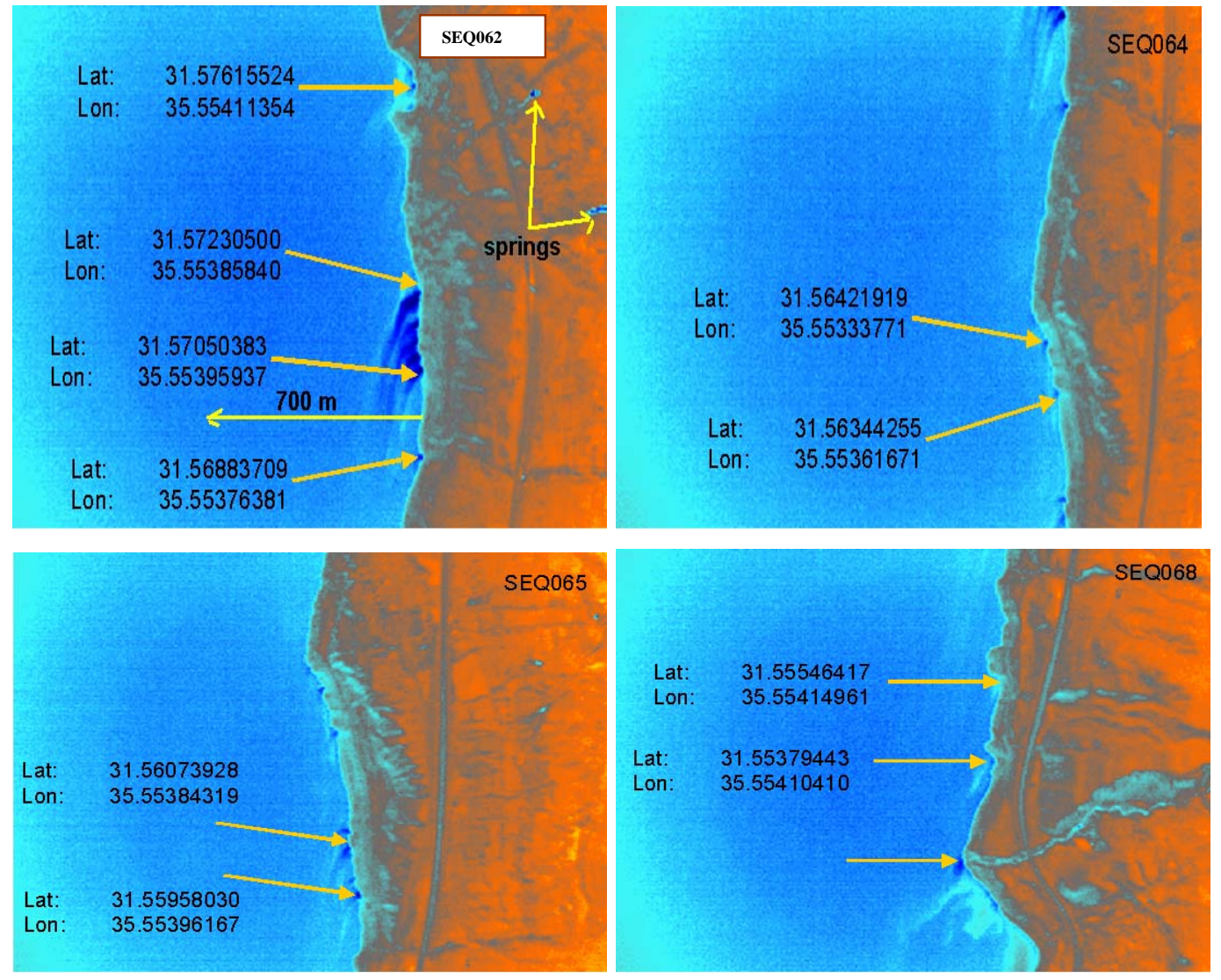

Figure (5-19 B): Groundwater flow distribution in Zara indicated by TIR images 
(C) Mujeb area
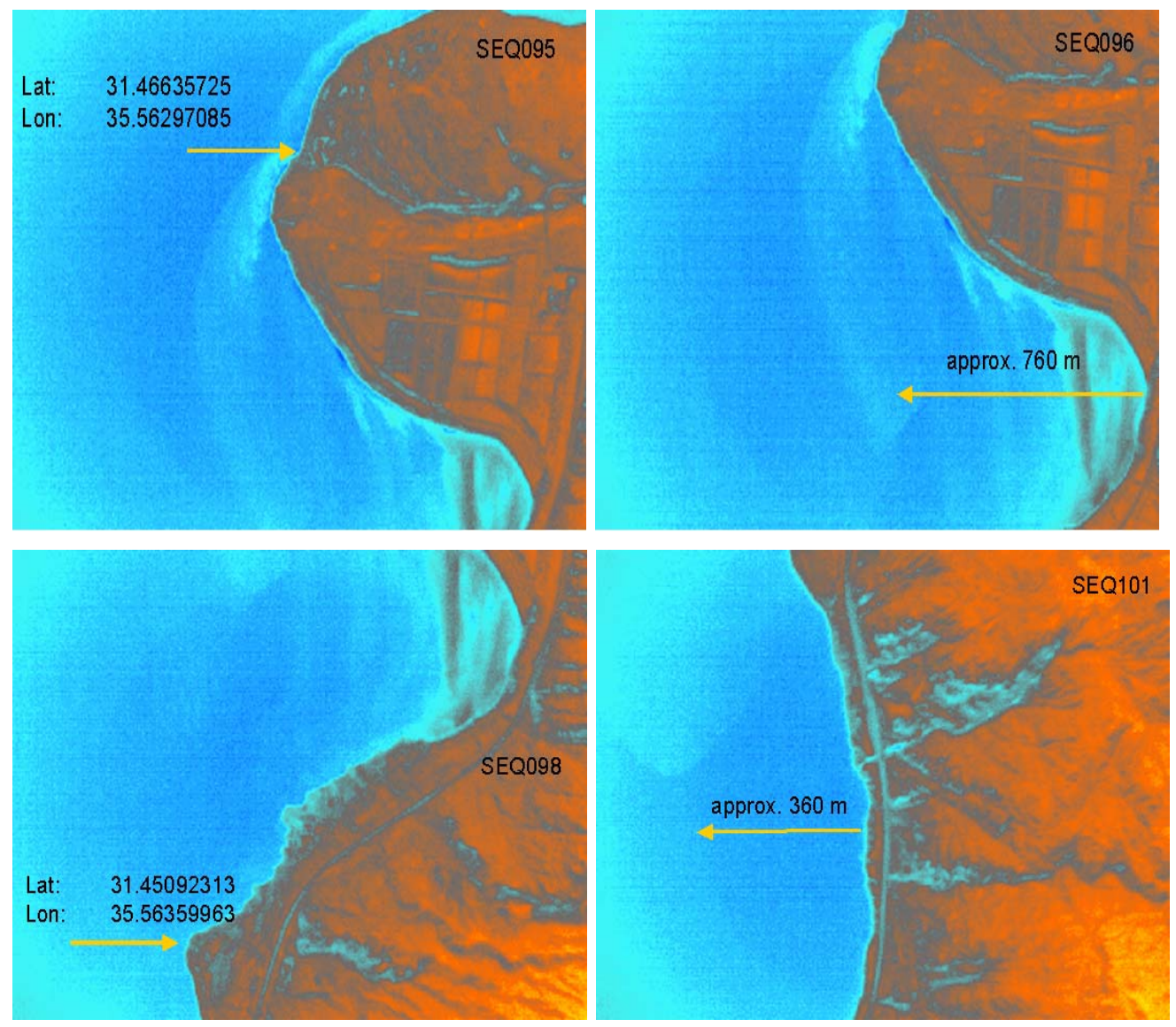

Figure (5-19 C): Groundwater flow distribution in Mujeb indicated by TIR images

\subsection{Electromagnetic Radiation (EMR)}

The results of the electromagnetic radiation (EMR) show that there are many active faults, farctures, joints and few of non-opened sinkholes along the coast of the Dead Sea extending from Sweimah in the north to Mujeb in the south. The zones are shown in (Fig. 5-20). Detailed results of the radiation anomalies illustrate in (Appendix IV).

In Sweimah area, the starting point of the profile has the coordinates of $31^{\circ} 43627$ $\mathrm{N}$ and $35^{\circ} 35334 \mathrm{E}$. High energy was observed in a distance of about $300 \mathrm{~m}$ from that point. The sinkholes were found at distances of 2455 to $2460 \mathrm{~m}$ from the starting point and many of the active fault and joints were found along this profile at distances intervals of about $310-315 \mathrm{~m}, 660-665 \mathrm{~m}$ and from $695-700 \mathrm{~m}$ from the starting point. The main interesting areas were at the distance of 2440-2450, 2635$2643 \mathrm{~m}$ and the main fractured zones were found between 2490 and $2505 \mathrm{~m}$ and 
from 2330 to the end of the profile at coordinates $31^{\circ} 45^{\prime} 45.07^{\prime \prime} \mathrm{N}$ and $35^{\circ} 34^{\prime}$ $33.48^{\prime \prime} \mathrm{E}$ with a distance of about $650 \mathrm{~m}$. Figure (5-21) shows the results of the EMR in Sweimah area.

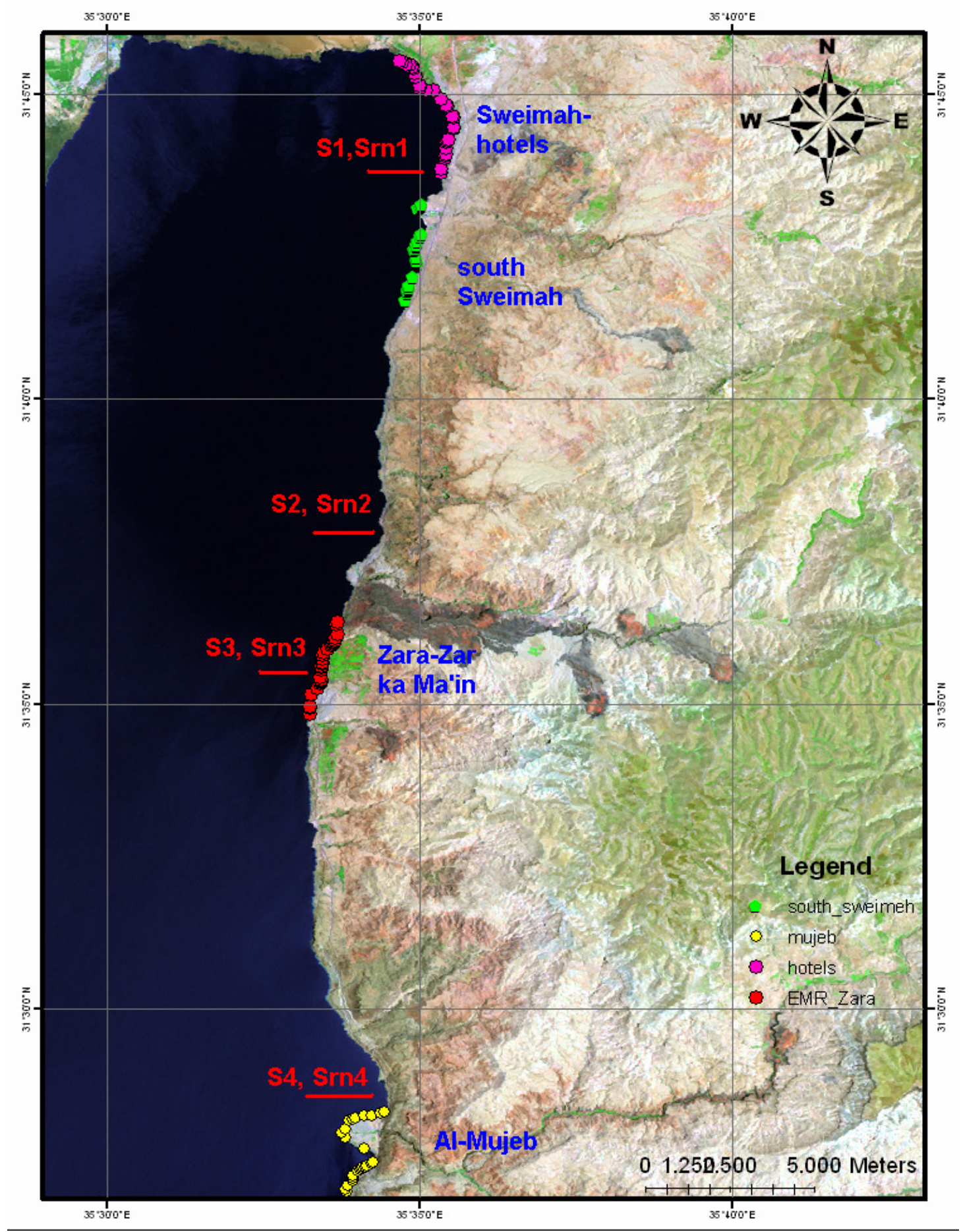

Figure (5-20): Locations of the EMR, EC and radon-222 stations 
Electromagnatic Radiation (Swaimah1)
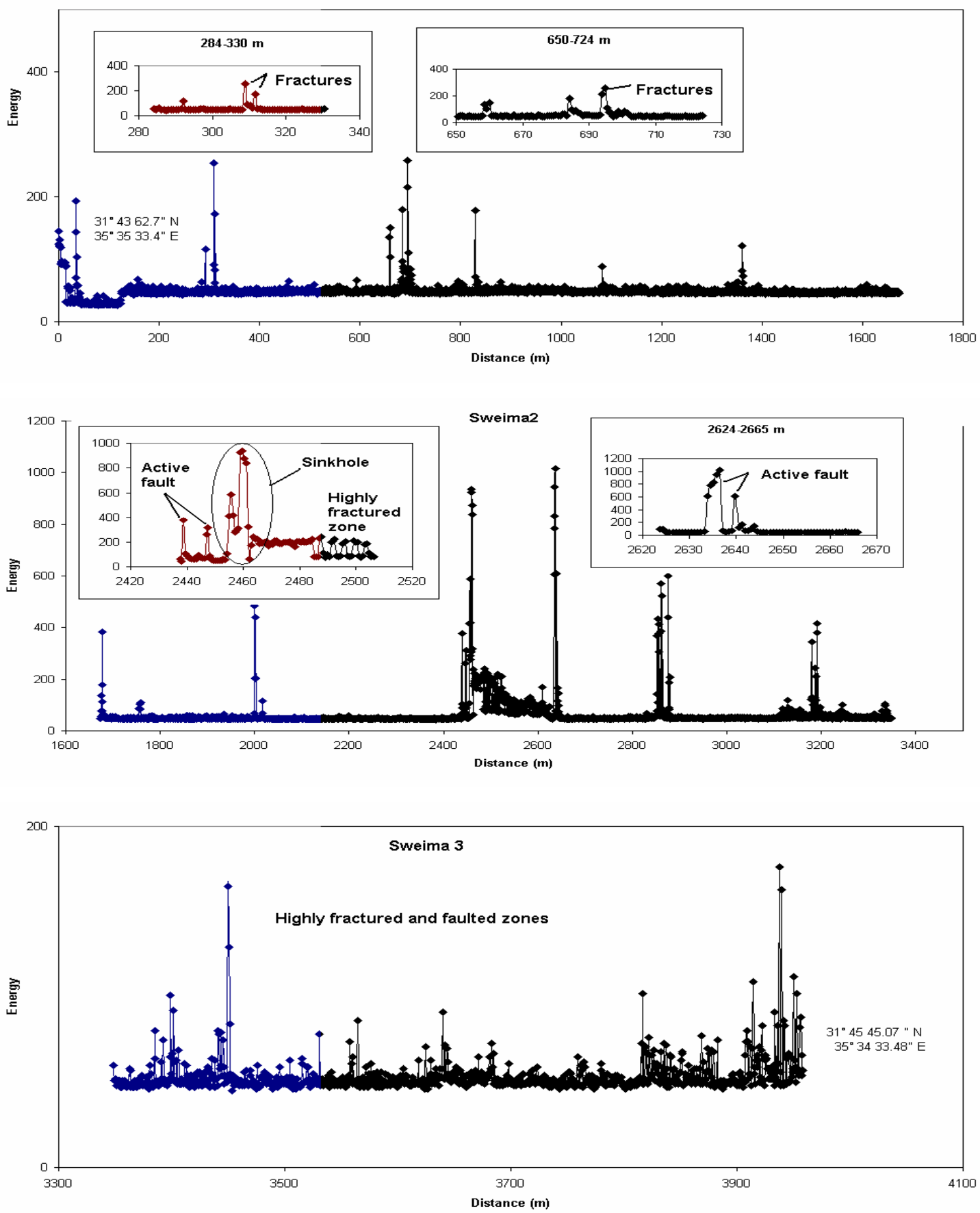

Figures (5-21): Magnitudes of EMR in Sweimah area.

South Sweimah profile started at coordinates $31^{\circ} 41^{\prime} 28.18^{\prime \prime} \mathrm{N}$ and $35^{\circ} 34^{\prime} 38.87^{\prime \prime}$ E. Many fractured zones were observed along the profile. A main highly fractured zone was observed at a distance between 790 and $1500 \mathrm{~m}$ from the starting point 
and another one between 880 and $1000 \mathrm{~m}$. A few sinkholes were observed between distances of about $890 \mathrm{~m}$ and $1265 \mathrm{~m}$ from the starting point. A main sinkhole was recognised at a distance of 2718 to $2730 \mathrm{~m}$ from the starting point (Fig. 5-22).

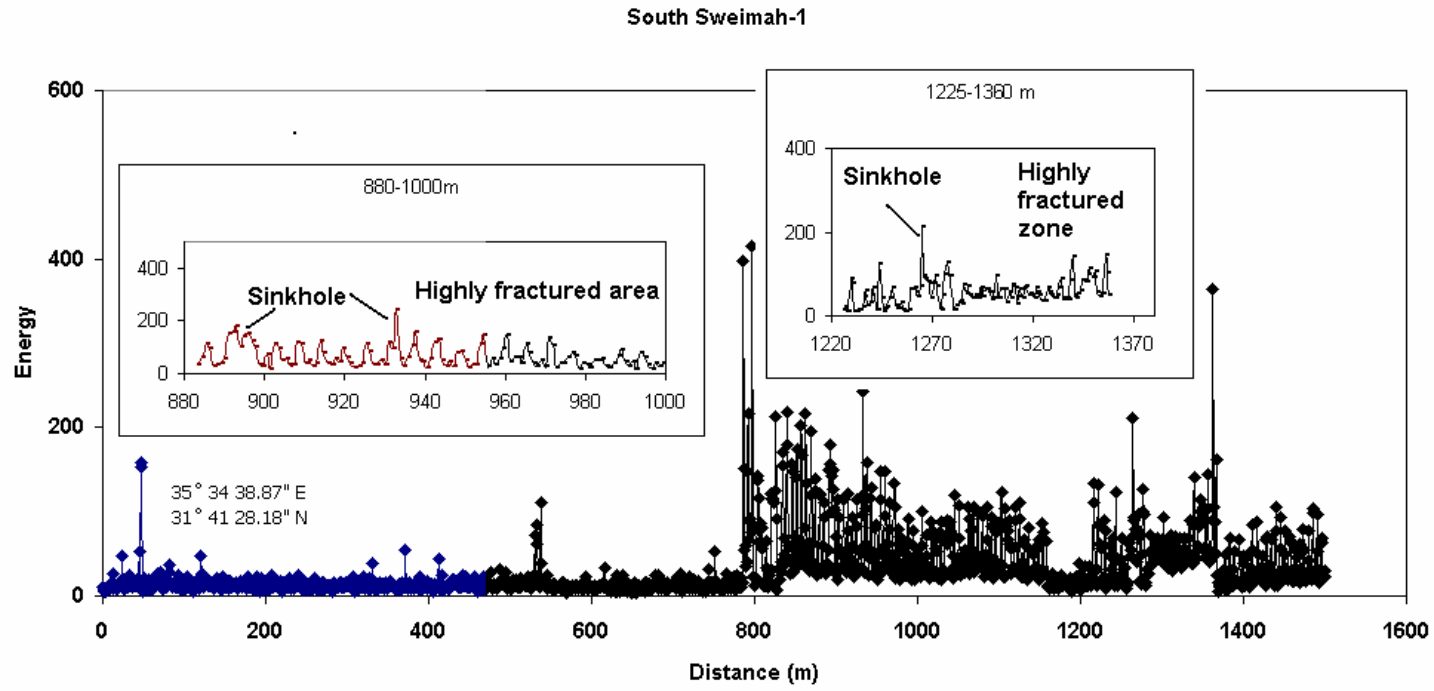

South sweimah-2

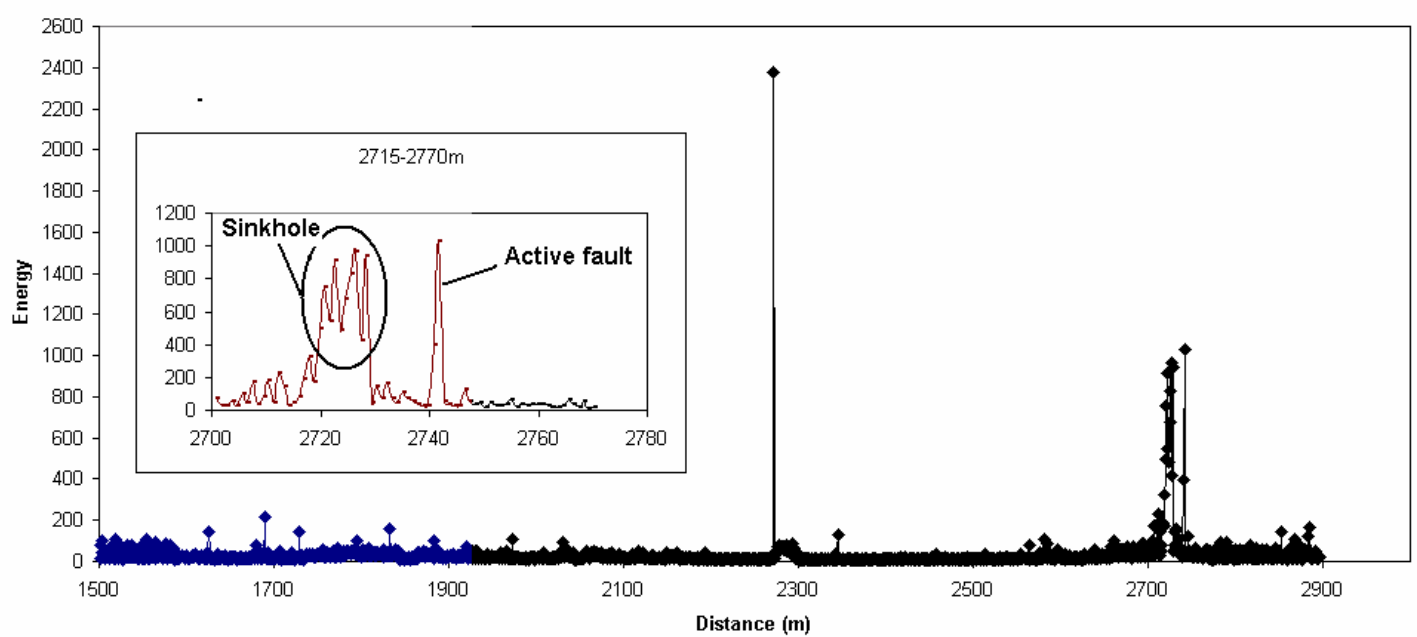

Figure (5-22): Magnitudes of EMR in south Sweimah area.

The EMR profile in Zara - Zarka Ma'in area is started at coordinate of $31^{\circ} 34^{\prime}$ 43.83" $\mathrm{N}$ and $35^{\circ} 33^{\prime}$ 99.2" $\mathrm{E}$. The radiation start after about 50-60 $\mathrm{m}$ from the starting point where the active fault start and then after about $80 \mathrm{~m}$ from the starting point another active small faults were observed (Fig. 5-22). As well nonopened sinkhole was found at a distance of about $2305-2310 \mathrm{~m}$ from the starting 
point. As well an active faults and fractured zone were recognised at the distance from about $2285 \mathrm{~m}$ to about $2320 \mathrm{~m}$ from the starting point.
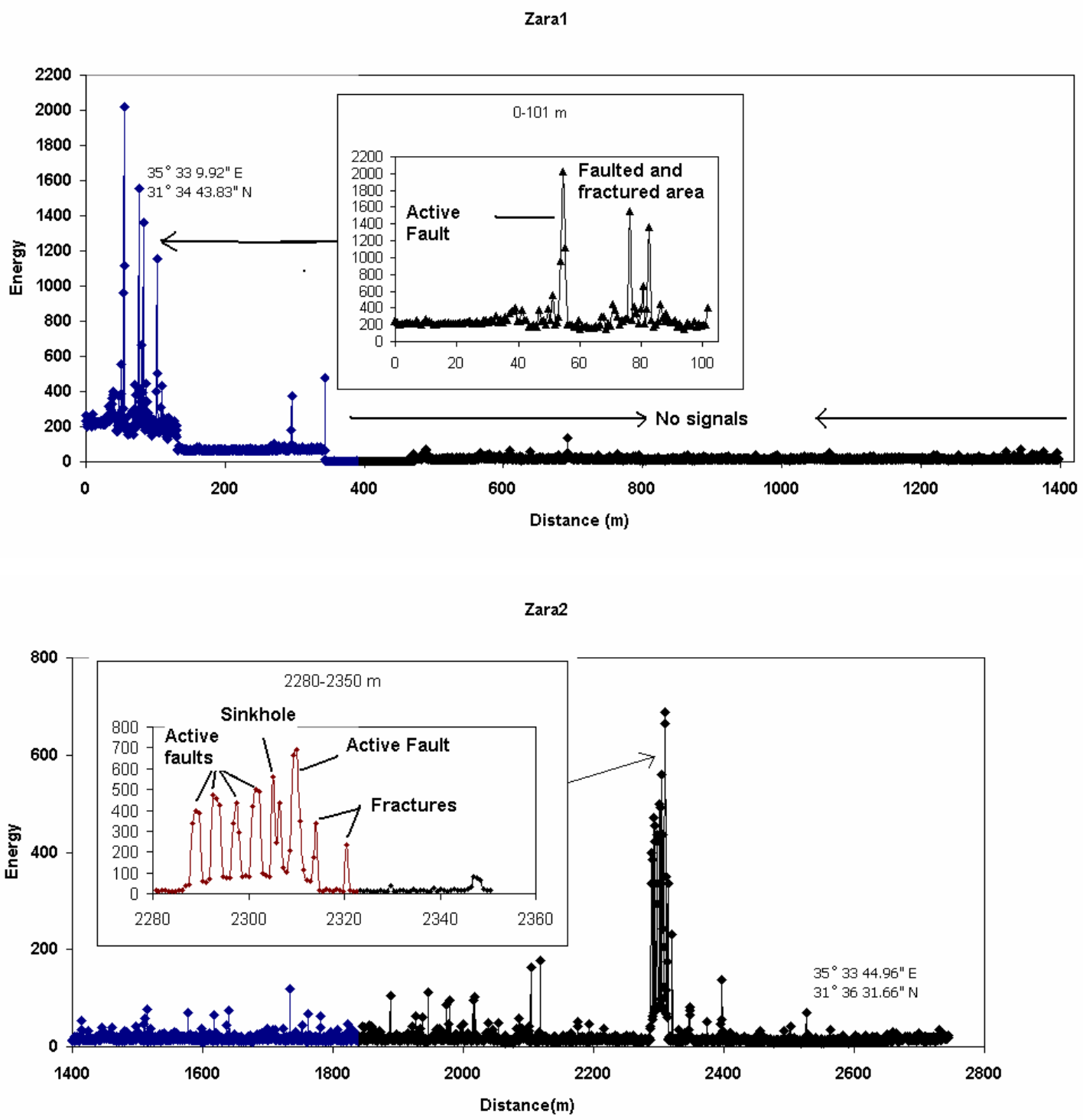

Figure (5-23): Magnitudes of EMR in Zara-Zarka Ma'in area

In Mujeb area the EMR results showed many fractured zones along the profile. The main features were at distances between 550 and $565 \mathrm{~m}$ and between 1148 and $1155 \mathrm{~m}$ from the starting point. A sinkhole was recognised at a distance between 140 and $150 \mathrm{~m}$ from the beginning point. As well a large fractured and faulted zone was observed between 1275 and $1380 \mathrm{~m}$ from that point (i.e at the end of the profile) at the coordinate of $31^{\circ} 28^{\prime} 39.92^{\prime \prime} \mathrm{N}$ and $35^{\circ} 34^{\prime} 25.40^{\prime \prime} \mathrm{E}$. Figure (5-24) shows the results of EMR in Mujeb area. 


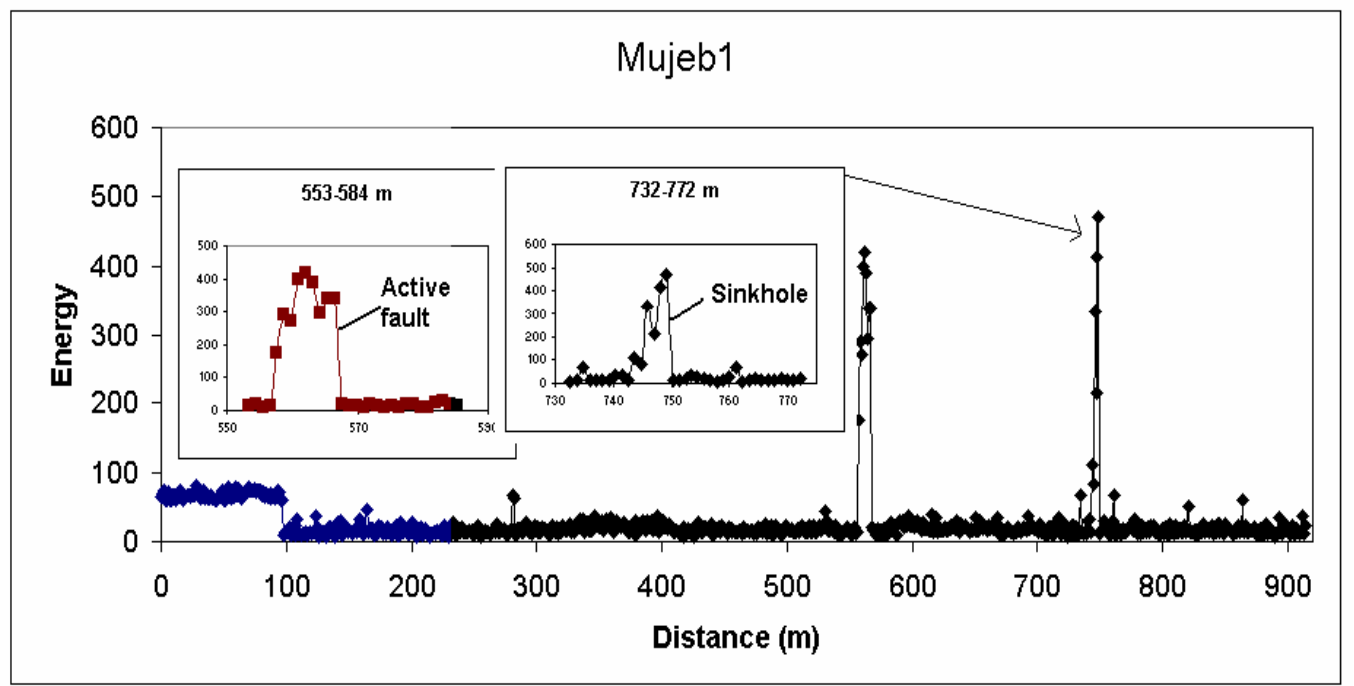

Mujeb1-2

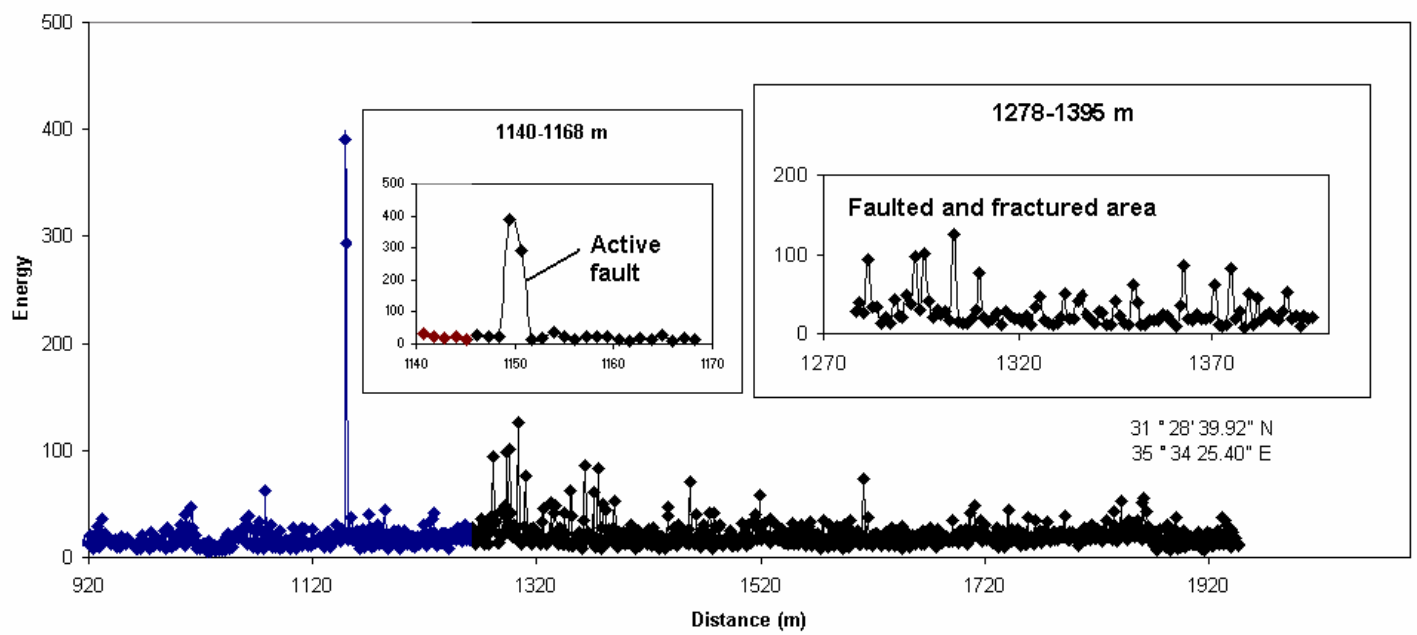

Figure (5-24): Magnitudes of EMR in Mujeb area.

The integration of the geology and the TIR and EMR results are explained as a spatial conception as shown in figure (5-25). 


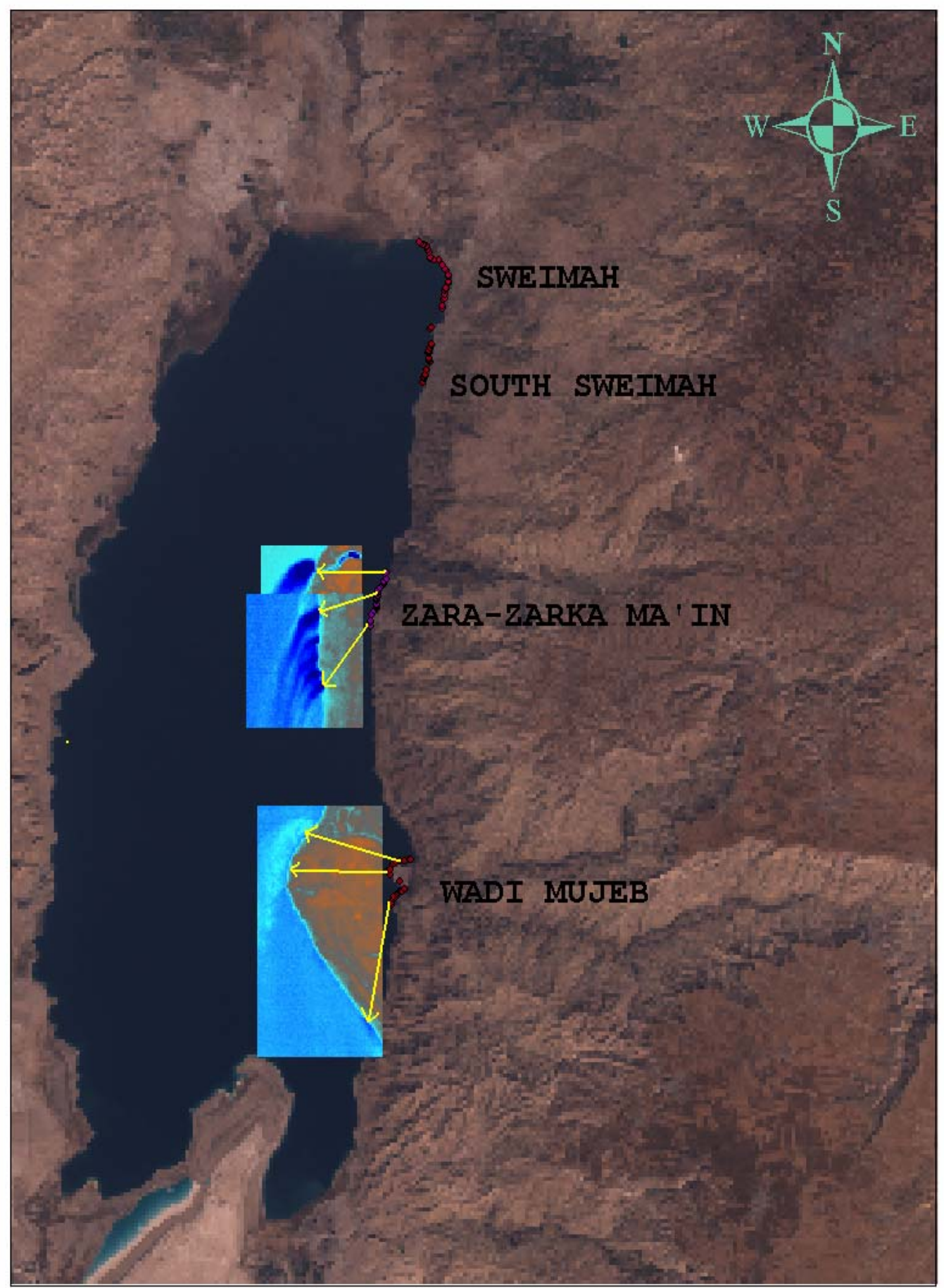

Figure (5-25): Spatial locations of the geological assessments, EMR and TIR

Figure (5-25) showed that the zones of discharge from TIR method coincide with results were getten from the EMR method 


\section{HYDROGEOLOGICAL CONCEPTUAL MODEL}

\subsection{General Outlines}

The geology of the Dead Sea area is quite complicated and includes both unconsolidated superficial lithology and bedrock outcrops. The area is characterized by a highly faulted with different trends and folded with a synclines extending from southeast to northwest along the Dead Sea. The faults at the area occurred due to a compression forces during the Late Cretaceous to Tertiary. These faults reactivated in Quaternary times and new faults, fractures and discontinuities created. These considered as a weakness zones for the discharge.

The bedrock is typically highly fractured at the surface and subsurface extending greater than 10s of meter deep. The fractures are often composed of two sets of vertical fractures at approximately right angles to each other, and a third, nearly horizontal, set. They may be observed directly in exposed bedrock. These fractures are widely distributed throughout the Dead Sea area.

These fractures are the principal sources of secondary permeability in many bedrock aquifers and then the recharge occurs chiefly through these faults and fractures. Then might be serving as paths for groundwater lateral and vertical movements.

Mountains, hills and Wadies characterize the topography of the Dead Sea area; the topography of the mountains commonly having steep slopes from east to west toward the Dead Sea coast.

As well the Dead Sea area is characterized by high differences in the hydraulic head, which provide the impetus for groundwater movement from the high head to the low head.

\subsection{Aquifers}

The main major aquifer systems within the Dead Sea basin are the upper aquifer Amman/ Al Hisa / Wadi Es-Sir $\left(B_{2}-A_{7}\right)$ system and the lower aquifer system Kurnub and older age sandstone formations (Zarka, Ram, and Disi).

\subsubsection{Amman Al Hisa Wadi Es-Sir Aquifer system $\left(B_{2}-A_{7}\right)$}

This forms one of the most important and extensive aquifer systems in the study area. It consists of two formations: The Wadi Es-Sir $\left(A_{7}\right)$, and Amman silicified limestone $\left(B_{2}\right)$. The $B_{2}$ and the $A_{7}$ formations are hydraulically connected due to the 
missing or limited lateral extent of the $\mathrm{B}_{2}$, separating them elsewhere (Salameh and Bannayan 1993).

This aquifer crops out widely in the escarpment to the east of the Dead Sea in the high rainfall areas. The $B_{2} / A_{7}$ formations consist of limestone, intercalated with laminas of marl (Hunting and Macdonald, 1965). The upper part contains phosphatic limestone and silicified phosphate. The Wadi Ghudran $\left(B_{1}\right)$ forms a thin aquiclude onsisting of marl and chalky marl in some places separting the $B_{2}$ from the $A_{7}$. The thickness of this system ranges between 170 and $325 \mathrm{~m}$.

The $B_{2}-A_{7}$ aquifer system receives direct recharge from precipitation which infiltrates through the soil and rock covers (Salameh and Bannayan, 1993) and indirect recharge from the adjacent aquifer and from the surrounding areas. But the direct recharge is limited in some areas located farther to the east of the Dead Sea due to overlying by lower permeability strate the Muwaqqar Chalk Formation $\left(B_{3}\right)$. According to Abu Ajameh (1980) the total direct and indirect recharges to this aquifer, in Zarka Ma'in sub-catchment is $6 \mathrm{MCM} / \mathrm{y}$. About $88 \%$ of this amount leaks downward to feed the lower aquifer and the rest appears as base flow of springs in the upper reaches of Wadi Zarka Ma'in.

According to Khdeir (1997) the average rainfall in Wadi Waleh sub-catchment (part of Mujeb catchment area) is $144.8 \mathrm{MCM} / \mathrm{y}$ for the five years period (1980-1985). Only $11 \%$ of this amount enters the $B_{2}-A_{7}$ aquifer as a direct recharge. Also, the aquifer in Wadi Wala sub-catchment is feeding with $2.2 \mathrm{MCM} / \mathrm{y}$ as indirect recharge from the lower aquifer and 7.3 MCM/y as lateral recharge from the adjacent high recharge mounds for the same period.

The discharge occurres from the aquifer through the base flow of the Wadies, spring flows and subsurface outflow toward the Dead Sea. Some amounts leak downward to recharge the deep aquifer (Salameh and Udluft, 1985). This aquifer is unsaturated along the eastern shores of Dead Sea, because it crops out in this area and it is essentially an unconfined aquifer.

\subsubsection{Lower Aquifer System}

This aquifer system includes the sandstone formations of different ages. The formations are Kurnub Sandstone of Lower Cretaceous age, Zarka sandstone of Triassic age, and Ram sandstone of Camprian age. These aquifers are interconnected. The aquifer system crops out along the Dead Sea Shore and in the lower reaches of Wadi Zarqa Ma'in and Wadi Waleh-Heidan, with a thickness of more than $600 \mathrm{~m}$ along the northern part of the Dead Sea in Wadi Zarka Ma'in and Hidan.

The aquifer is mainly composed of sandstone. It becomes hydraulically extremely complex due to intercalation shale and clays. Because that the permeability is different in lateral and vertical directions. In some locations Lower Zarqa shale and 
clays form an aquiclude confining the underlying saturated Cambrian sandstone (Umm Ishrin and Disi). But in most of the study area the Zarqa shale and clays are absent. Therefore, the whole sequence can be treated as one hydraulicly connected aquifer (Salameh and Udluft, 1985). This lower aquifer system underlies the study area with a total thickness of more than $600 \mathrm{~m}$. The aquifer is exposed along the area of very low rainfall rates. Hence, direct recharge to this aquifer system is very low and negligible. The main recharge to this aquifer system takes place through the downward leakage from the upper aquifer and aquitards systems through the weakness zones of faults and fracturs in the $A_{1-6}$ (Salameh and Udluft, 1985). The main outflow from the aquifer takes place along the Dead Sea in the form of springs and seepages from Kurnub sandstone along the Dead Sea shorelines. The main spring discharge is in Zara and Zarqa Ma'in areas in the form of thermal hot springs. In addition, the main discharge takes place as subsurface outflows toward the Dead Sea (Salameh and Bannayan, 1993).

\subsubsection{Minor Aquifers}

There are two minor aquifers in the Dead Sea area. Na'ur aquifer $\left(A_{1-2}\right)$ consists of limestones intercalated with thick sequences of marl. It crops out in the Dead Sea area. This aquifer becomes turns into an aquitard locally to the east of the Dead Sea. The second minor aquifer is Hummar $\left(A_{4}\right)$. It consists of dolomitic limestones with a secondary permeability due to the presence of fractures and joints. Some springs issue from these aquifers to the east of the Dead Sea as Al Zarka spring in the upper of the Zarka Ma'in Wadi.

\subsection{Aquitards}

The formations of Fuheis $\left(A_{3}\right)$ and Shueib $\left(A_{5-6}\right)$ form a main aquitards in the area. In some places these include the minor aquifers mentioned above. They separate the lower main aquifer from the upper main aquifer. They crop out in the easteren shores of the Dead Sea.

\subsection{Groundwater Movements}

Based on the geological maps, (http://exact-me.org/overview/p17.htm) and the available data from (WAJ) the Dead Sea basin was constructed and modified as in (Fig. 6-1). The Dead Sea basin is bisected by Siwaqa fault into a northern and a southern part. The fault forms a permeable discontinuity (GTZ, 1995). The groundwater flows in a west north western direction and toward Wadi Wala. The figure shows that the upper aquifer (B2/A7) crops out in the Dead Sea basin area. On the other hand this aquifer absent on the north western part of the basin, while the minor aquifers and the aquitards crop out. The lower aquifers (Kurnub and 
Umm Ishrin) crop out at the area adjacent to the Dead Sea shores. Figure (6-1) shows the groundwater flows toward the Dead Sea.

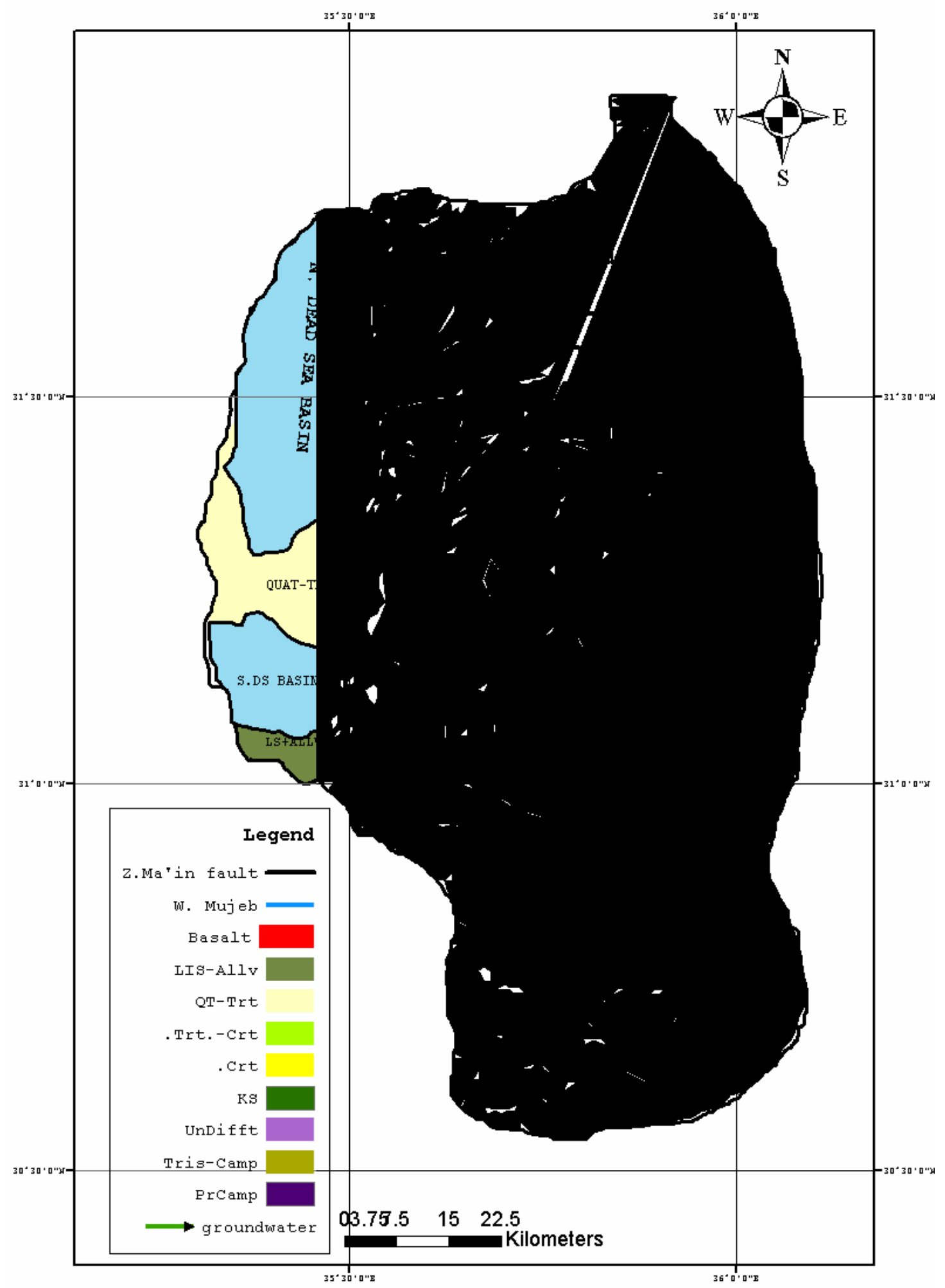

Figure (6-1): Dead Sea basin showing the outcropping rocks and the groundwater 
directions (The arrows donate to GW directions)

Based on, the geological maps, the structural patterns, the geological model of the study area and the hydraulic model of central Jordan after (Salameh and Udluft, 1985) a conceptual hydrogeological model of the Dead Sea was produced along NE-SW direction (Fig. 6-2). The model shows the main upper aquifer $\left(B_{2} / A_{7}\right)$ underlay with the minor aquifers, aquitard and lower aquifer (Kurnub-Zarka-Ram groups). It shows also that the groundwater flows from the east and northeast scarpments toward the Dead Sea. It shows saltwater intrusions from the Dead Sea toward the east direction and enters the lower aquifers. The precipitations infiltrate downward to feed the unsaturated $\left(B_{2} / A_{7}\right)$ aquifer through the overlay soil and rocks. This water leaks downward to feed the lower aquifers through fractures and joints present in the aquitards which separate the upper aquifer from the lower aquifer. As well some of the groundwater flow upward direction from the minor aquifer and feed the upper unsaturated aquifers. 


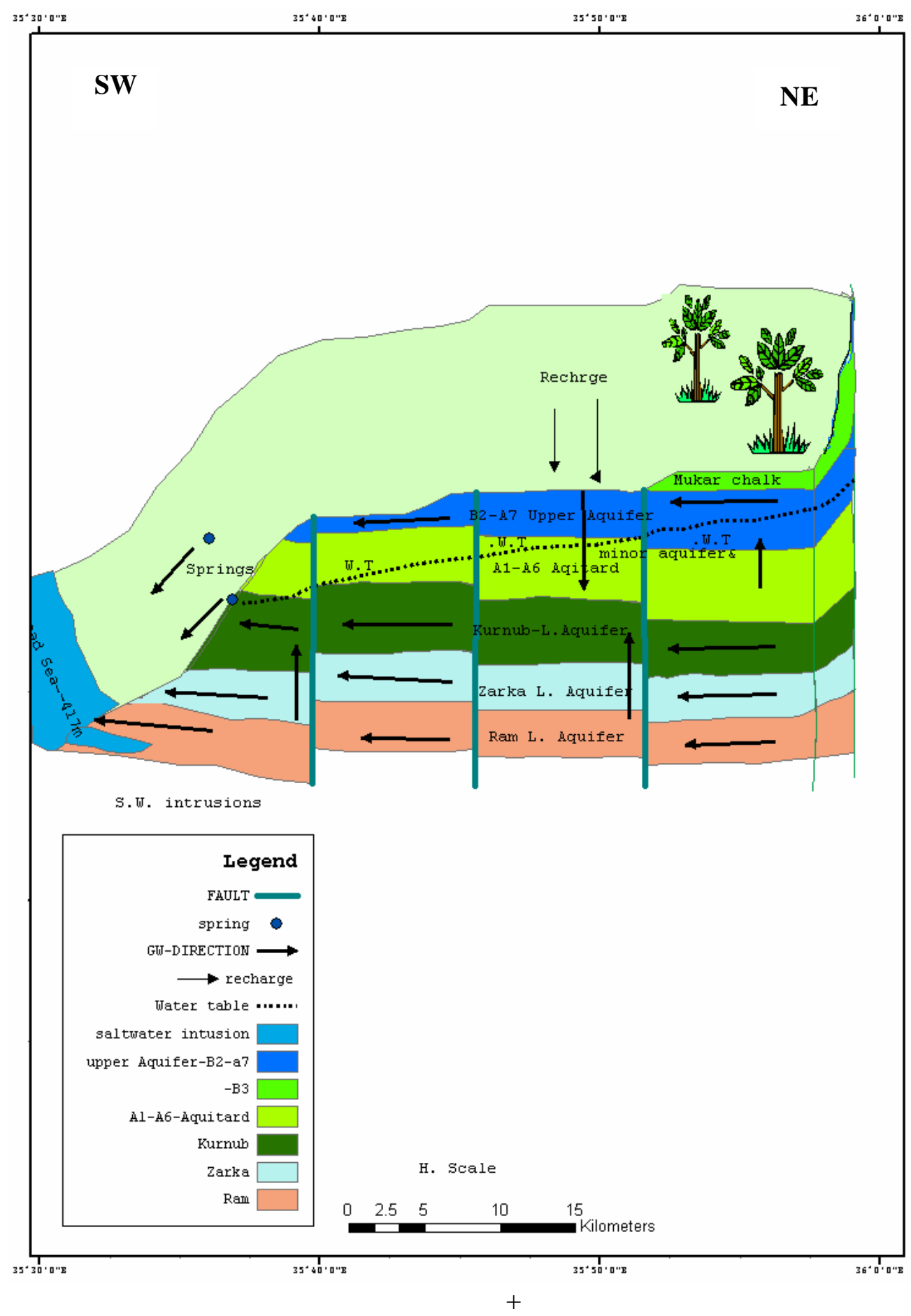

Figure (6-2): Conceptual groundwater model along E-W profile 


\section{SUMMARY and FUTURE PROSPECTS}

\subsection{Summary}

The Dead Sea Rift zone is the main structural element governing the geomorphology, hydrology and hydrogeology of Jordan. Dead Sea located in the middle and forms an active part of the African-Syrian Rift, which extends from east Africa through the Red Sea, Wadi Araba, Dead Sea and Jordan Valley to southern Turkey.

The main purpose of this study is to locate the discharge zones and to estimate the quantity of groundwater that discharged along the eastern shores of the Dead Sea as submarine springs, in accordance to the electrical conductivity and temperature survey with the depth, chemical tracer (radon-222), thermal infrared imagery and electromagnetic radiation techniques. Using the results obtained from this study to determe the availability of exploitable water resources that can be abstracted to assist in the water supply along the shores of the Dead Sea. This might be provided the basis for future development for the area.

The geological model of the study area was developed. This model shows that the geological units dip to the west and southwest directions toward the Dead Sea. In the area adjacent to the shores of the Dead Sea the upper aquifers (B2/A7) were eroded and the lower aquifers (Kurnub sand stone, Zarka and Ram sandstone group) crop out. According to the geological model and based on the data obtained from different sources a conceptual hydrogeological model is constructed and the groundwater flow directions were expected. It shows that the groundwater flows from the east and northeast to the west and southwest toward the Dead Sea. At the east of the Dead Sea the upper aquifer is unsaturated because of it crops out. It gained its water from the direct recharge as infiltration from the precipitation and as indirect recharge as upward leakage from the lower aquifer through the fractures and joints presented in the minor aquifer and aquitard that separated the upper aquifer from the lower aquifer.

Laboratory experiments, which are used for calibrating the electrodless sensor and for checking the $\mathrm{EC}$ compensation with the $\mathrm{T}$, show that the relationship between the $\mathrm{EC}$ and the $\mathrm{T}$ is a quadratic and the sensor works properly corresponding to $\mathrm{T}$ compensation at $25^{\circ} \mathrm{C}$. As well the labratory experements show that the $\mathrm{EC}$ increases with the increase in the T when TDS is fixed, while with the increasing the TDS at $25^{\circ} \mathrm{C}$ the $\mathrm{EC}$ decrease.

The relationship between EC and TDS was obtained in the laboratory for high saline water as that as the Dead Sea. The relationship shows that the EC reached its maximum value at $202 \mathrm{mS} / \mathrm{cm}$ at a salinity of $267 \mathrm{~g} / \mathrm{l}$. This value decreases with the increasing salinity and it reached $176 \mathrm{mS} / \mathrm{cm}$ at a salinity of about $420 \mathrm{~g} / \mathrm{l}$. The 
TDS was calculated using this relationship for all the EC values obtained from the field measurements. These values were compared with a TDS values were measured using gravimetric technique. A good comparison between the calculated values and the measured values was observed with a difference less than $5 \%$.

Relating to the EC and T measurements with the depth the Dead Sea water divides into two layers. The first layer is from the Dead Sea surface down to a depth of approxmetly $40 \mathrm{~m}$. The second layer extends from $40 \mathrm{~m}$ to the final depths of the profiles. The first layer subdivided into two members. The upper member extends from the Dead Sea surface down to $15-25 \mathrm{~m}$ and characterized by a low TDS and high in EC, while the second member extends from 15-25 to about $40 \mathrm{~m}$ and characterized by a higher salinity than that of the upper member and the lower layer. Submarine groundwater discharge into the Dead Sea was observed in the upper $16 \mathrm{~m}$ in average in Sweimah area in the north edge of the Dead Sea, while it was observed in the upper $25 \mathrm{~m}$ in average in Zarka Ma'in area and at the upper $15 \mathrm{~m}$ in average in Zara area in the middle part of the Dead Sea. Finally the submarine groundwater discharge was observed in the upper $18 \mathrm{~m}$ in Mujeb area in the southern part of the Dead Sea.

The reason for a very high TDS value in the lower member of the Dead Sea water is due to the high evaporation from the surface of the Dead Sea in the summer season. So the salinity become too high and its density increase. Then the dense saline water sinks down and the fresh groundwater, which flow into the Dead Sea from a depth of $15-25 \mathrm{~m}$ floats (upwelling) to the surface. As well the TDS values, at the surface, change with the change in the distances from the shoreline. It decreases with the increase of the distances away from the shoreline due to the decrease in temperature.

Radon-222 inventories and its activities in the groundwater are the two basic measurements needed to complete the radon model. Radon-222 advection to atmosphere and the radon productions were estimated to complete the radon budget calculations were estimated or measured. Four stations were considered according to the geology, hydrogeology and structure features of the area surrounding the Dead Sea area for carrying out the radon-222 measurements. The advection rates in these stations were calculated and the quantities of the groundwater discharge were computed by multiplying the advection rate with the area of discharge for each station.

The advection rate in Sweimah area is $0.1328 \mathrm{~m} /$ day and the quantity of submarine groundwater discharge is $135.7 \mathrm{MCM} / \mathrm{y}$. The advection rate in Zarka Ma'in area is calculated as $0.1324 \mathrm{~m} /$ day and the discharge is $128.5 \mathrm{MCM} / \mathrm{y}$. The advection rate in Zara area is $0.066 \mathrm{~m} / \mathrm{day}$ and the discharge is $33.7 \mathrm{MCM} / \mathrm{y}$ and the advection rate in Mujeb area is $0.0651 \mathrm{~m} /$ day and the discharge is $90.3 \mathrm{MCM} / \mathrm{y}$. The total quantity of the submarine groundwater discharge into the eastern shores of the Dead Sea in all stations is estimated as $388.2 \mathrm{MCM} / \mathrm{y}$. This value was compared with the groundwater discharge quantity $480 \mathrm{MCM} / \mathrm{y}$ obtained by using the water 
budget for the both sides (eastern side-Jordan, and the western side-Israel and Palestine). The amount of discharge using water budget for the period from 1957 to 1995 was calculated by (Salameh and El-Nasir, 1999). The reason for this difference in the two quatities obtained from the two methods is because of the water budget considered the whole Dead Sea in both sides, while the Rn-222 method considere only the eastern shoreline of the Dead Sea. Also the Rn-222 results show that the highest concentrations of radon are at the area close to the shoreline and decreases with the increase in the distances from the shoreline. These mean that the highest amount of submarine groundwater discharge is in the locations close to the shoreline. Also, the highest concentrations are at a depth of $12 \mathrm{~m}$ in Sweimah, Zara and Mujeb areas, while it is at a depth of $7 \mathrm{~m}$ in Zarka Ma'in area. Generally relating to radon-222 results the groundwater discharge occurs in the upper $20 \mathrm{~m}$ of the Dead Sea water. These results coincide with the results obtained by using EC and T results. As well the SGD is estimated about $181 \mathrm{MCM} / \mathrm{y}$ by using mixing of TDS, and it is estimated about $57 \mathrm{MCM} / \mathrm{y}$ by using Darcys' law. In conclusion the SGD into the eastern shores of the DS might be between 200 and $300 \mathrm{MCM} / \mathrm{y}$

Thermal infrared imagery is the other method that used for locating the submarine groundwater discharge into the eastern shores of the Dead Sea. It is an effective method to assess to large-scale areas and to acquire information about specific locations of groundwater discharge. The contrast in temperatures between the warm groundwater and the cold surface water of Dead Sea was obvious. The warm water was considered as due to groundwater discharge in wintertime when the images were taken out. Many of groundwater discharge zones were found along the study area. The major zones were found in Zarka Ma'in, Zara and Mujeb areas. The length of the discharge zones were estimated by using the TIR about $3800 \mathrm{~m}$ and about $750 \mathrm{~m}$ wide in Zarka Ma'in area and in Zara area the length of the discharge zones was about $2000 \mathrm{~m}$ with $750 \mathrm{~m}$ wide. On the other hand the discharge zones length in Mujeb area was about $2400 \mathrm{~m}$ and its width extends between 360 and $760 \mathrm{~m}$.

The results of the electromagnetic radiation measurements (EMR) showed that there are many small active faults and highly fractured rocks along the eastern shores of the Dead Sea. These faults and fractures consider as a zones of weaknesses for increasing the groundwater discharge. As well the results showed that there are some non-opened sinkholes in Sweimah area, in Zara Zarka Ma'in and Mujeb areas. The most active fault and fractured zones were found in Sweimah area in the northeren corner of the Dead Sea.

\subsection{Zusammenfassung}

Die Tote-Meer-Störungszone (Dead-Sea-Transform) ist das strukturelle Hauptelement, das die Geomorphologie, die Hydrologie und die Hydrogeologie von 
Jordanien wesentlich beeinflußt. Jordanien liegt im nordwestlichen Teil der Arabischen Halbinsel. Das Tote Meer befindet sich in der Mitte dieser Störungszone, die einen aktiven Teil des Afrikanisch-Syrischen-Riftsystems darstellt. Dieses System läuft von Ostafrika durch das Rote Meer und den Wadi Araba, das Tote Meer und die Jordan-Tal - Senke bis in die Südtürkei.

Der Hauptzweck dieser Studie war es, die Grundwasser-Austrittszonen entlang der östlichen Uferlinie des Toten Meeres darzustellen und die Mengen quantitativ zu bestimmen. Die Studie basiert auf der Anwendung folgender Techniken: Temperatur- und Tiefen-Abhängigkeit der elektrischen Leitfähigkeit; Verfolgung eines chemischen Tracers (Radon 222); thermische Abbildung durch InfrarotAufnahmen. Die Mengen des austretenden Grundwassers, die mit dem Radon222-Indikator ermittelt wurden, wurden mit den Mengen verglichen, die mittels Wasserbilanztechniken bestimmbar sind. Die abschließenden Resultate dieser Studie sollen für die Bestimmung der verwertbaren Wasservorräte verwendet werden, die zur Wasserversorgung entlang den Ufern des Toten Meeres entnommen werden können.

Am Anfang der Studie wurde das geologische Modell des Untersuchungsgebietes entwickelt. Dieses Modell zeigt, daß die geologischen Schichten nach Westen und Südwesten in Richtung zum Toten Meer hin eintauchen. Die oberen Aquifere (B2A7) fehlen im östlichen Uferbereich des Toten Meeres, aber die unteren Aquifere (Kurnub-Sandstein-Gruppe und Ram-Gruppe) streichen hier am Rand des Toten Meeres aus. Außerdem gab das Eintauchen der Schichten eine generelle Idee über die Fließrichtungen des Grundwassers. Es bewegt sich vom Osten und Nordosten von den Hochländern nach Westen und Südwesten in Richtung zum Toten Meer.

Die Laborexperimente zeigten, daß das Verhältnis zwischen der elektrischen Leitfähigkeit und der Temperatur für den Sensor, der in dieser Arbeit benutzt wurde, durch eine quadratische Funktion beschrieben wird. Zum Anderen wurde bei der Laborarbeit mit den Tote-Meer-Wasserproben gefunden, daß sich die elektrische Leitfähigkeit (EC) erhöht mit der Zunahme der Temperatur für den Fall eines konstanten unveränderten Gesamt-Lösungsinhalts (TDS). Wenn dagegen der TDS erhöht wird, dann sinkt die elektrische Leitfähigkeit bei vergleichbarer Temperatur. Dieser Befund wurde im Labor überprüft und er entspricht den Beobachtungen, die im Feld gewonnen wurden. Abhängig von den Bestimmungen der elektrischen Leitfähigkeit, Temperatur und Tiefe wurde der Wasserkörper des Toten Meeres in zwei Schichten geteilt. Die erste Schicht beginnt an der Oberfläche und reicht in eine Tiefe von $40 \mathrm{~m}$. Die zweite beginnt bei $40 \mathrm{~m}$ und dehnt sich dann bis zur abschließenden Tiefe der Meßprofile aus. Die erste Schicht wurde in zwei Glieder unterteilt, von denen das obere sich von der SeeOberfläche bis in etwa 15 - 25 m Tiefe erstreckt, dessen Wasser sich wegen des Grundwasserzustroms durch eine relativ niedrige Salinität auszeichnet. Das zweite Glied von etwa 17- $25 \mathrm{~m}$ bis in eine Tiefe von ca. 40m hat dagegen eine höhere 
Salinität nicht nur als das überlagernde sondern auch als das darunter folgende Seewasser. Dies wird erklärt durch einen Prozess, bei dem die hohe Verdampfung direkt an der Oberfläche des Toten Meeres die Salinität und damit die Dichte des Wassers so erhöht, daß eine Instabilität entsteht. Das hochsalinare Wasser sinkt ab unter das leichtere, durch den Grundwasserzustrom bis in eine Tiefe von $25 \mathrm{~m}$ geringer salinare Wasser, das im Austausch nach oben aufströmt.

Radonbilanzen und Aktivitäten von Radon-222 im Grundwasser das dem Toten Meer zufließt, sind die beiden grundlegenden Bestimmungsgrößen, die für die Radon-Modellabschätzungen notwendig sind. Andere notwendige Komponenten für die Komplettierung des Radon-Budgets wurden gemessen oder geschätzt. Advektion von Radon-222 in die Atmosphäre wurde geschätzt und die RadonProduktion wurde gemessen und errechnet. Vier Stationen wurden für die Radon222 Messungen berücksichtigt, abhängig von der Geologie und Hydrogeologie des Gebietes. Die Advektionsraten im Toten Meer wurden bestimmt und die Menge des Grundwasserzuflusses errechnet, indem die Advektionsrate mit der Fläche des Zuflusses an jeder Station multipliziert wurde. Die Advektion an Station 1 wurde bestimmt zu $0.1328 \mathrm{~m} / \mathrm{Tag}$, was einen Grundwasserzufluss von 135.7 MCM/Jahr ergab. Die Advektion an Station 2 wurde bestimmt mit $0.1324 \mathrm{~m} / \mathrm{Tag}$ entsprechend $128.5 \mathrm{MCM} / \mathrm{Jahr}$. An Station 3 war die Advektion $0.066 \mathrm{~m} / \mathrm{Tag}$ woraus sich ein Zufluss von 33.7 MCM/Jahr ergab, und die Advektion an Station 4 wurde mit $0.0651 \mathrm{~m} / \mathrm{Tag}$ bestimmt entsprechend einem Zufluss von 90,3 MCM/Jahr. Die Gesamtmenge des Grundwasserzuflusses aller Stationen am Ostufer des Toten Meeres wurde zu etwa 388.2 MCM/Jahr geschätzt. Dieser Wert wurde mit einem Zufluss von $480 \mathrm{MCM} / J a h r$ verglichen, der erhalten wurde auf der Basis einer Wasserbilanz für das gesamte Tote Meer unter Einschluss aller Ufer (des Ost-Ufers in Jordanien und des West-Ufers in Israel und Palästina). Die Zuflussmengen wurden mittels einer Wasserbilanz berechnet, die Statistik bis zum Jahr 1995 benutzt. Aber der Zufluss dürfte heute viel höher sein, da der Spiegel des Toten Meeres beständig gesunken ist. Außerdem dürfte der Grund für den Unterschied der beiden Bilanzen sein, daß die Berechnung des Wasserbudgets für das ganze Tote Meer an beiden Seiten gilt, während die Bestimmung des Radon222 Flusses nur die östliche Küste berücksichtigt. Weiterhin haben die RadonResultate gezeigt, daß die höchsten Konzentrationen im Gebiet zunächst der Küste gefunden werden und die Konzentrationen mit der Entfernung von der Küste abnehmen. Das bedeutet, daß der maximale Eintrag nahe der Strandlinie erfolgt. Zusaetzlich wurde der submarine Grundwasser-Zustrom zu $181 \mathrm{MCM} / \mathrm{jahr}$ abgeschaetzt, basierend auf der mischung der TDS- Gehatter, und mittels Darcy's Gesetz ist $57 \mathrm{MCM} / \mathrm{jahr}$. Zusammenfassend liegt der submarine GrundwasserZustrom wohl zwischen 200 und 300 MCM/jahr.

Die Aufnahme thermischer Infrarot-Bilder war die dritte Methode, die für die Darstellung der Unterwasser-Grundwasseraustritte verwendet wurde. Es ist eine wirkungsvolle Methode um großräumige Bereiche schnell zu erfassen und um Informationen über spezifische Positionen des Grundwasseraustritts zu gewinnen. Der Kontrast in den Temperaturen zwischen dem Grundwasser , das höhertemperiert ist, und der niedrigen Temperatur des Oberflächenwassers des Toten Meeres war offensichtlich. Die beobachteten höheren 
Oberflächentemperaturen während des Winters, als die Aufnahmen durchgeführt wurden, konnten daher als Grundwasser-Austritte interpretiert werden. Viele Grundwasseraustritte wurden entlang des untersuchten Küstenabschnitts erkannt. Die Hauptzonen wurden im Gebiet von Zarqa Ma 'in , Zara und Al-Mujeb gefunden. Die Länge der Austrittszone bei Zarqa Ma'in wurde zu 3800m, die Breite zu etwa $750 \mathrm{~m}$ geschätzt, und im Zara-Gebiet war die Austrittszone etwa $2000 \mathrm{~m}$ lang und $750 \mathrm{~m}$ weit. Andererseits waren die Austritte im Al-Mujeb -Gebiet ungefähr $2400 \mathrm{~m}$ lang und zwischen 360 und $760 \mathrm{~m}$ breit.

Die Resultate der elektromagnetischen Messungen (EMR) zeigen, daß es viele kleine aktive Störungen und stark geklüftete Gesteine an der Ostküste gibt. Diese Störungen und Brüche sind Wegsamkeiten für Grundwasser-Zutritte. Die Resultate lassen außerdem vermuten, daß es einige nicht durchgebrochene Lösungshohlräume im Sweimah - Gebiet gibt. Diese Beobachtung könnte eine Begründung für die höhere Radon-222-Advektion dort geben, wenn man diese mit den anderen Stationen vergleicht.

\subsection{Future Prospects}

Future work should focus on the following recommendations to obtain a complete concept on the groundwater discharge into the Dead Sea.

$>$ Using the direct physical measurements as seepage flux meters techniques in Sweimah area, in Zara and Zarka Main area, in Mujeb area and in Ghor Haditha area. In order to determine the wide of submarine groundwater discharge for assuring of this study.

- Using the hydrochemistry methods to compare the lons and Cations content of the spring surrounding the area and the Dead Sea water content to calculate the discharge using a mass balance technique.

$>$ Carry out the thermal infrared images along the Dead Sea shore with very high resolution less than 5 meters in order to locolize the discharge from the seepages at the shoreline.

$>$ For future study using the thermal infrared imagery. It is recommended to measure the water surface temperature at the same time of carrying out the images, and to match the GBS time with the thermal camera time in order to do correct mosaic for all images.

$>$ Carry out the thermal infrared Images for the area east of the Dead Sea to investigate new springs surrounding the Dead Sea. 
Studying the rock alterations and the gypsum sedimentions along the Dead Sea to determine the history of the discharge in the past time.

Using Radium and $\mathrm{CH} 4$ isotopes to estimate the Discharge and compare the results with the result have getten from this study.

$>$ Carry out a high-resolution aerial photography along the Dead Sea to merge the groundwater discharge and the sinkholes along the Dead Sea.

Long-term monitoring of water quality of groundwater discharge surrounding the Dead Sea is recommended to identify the significance of land use impacts upon submarine groundwater discharge.

Feed the Dead Sea with water from other sources to increase its level, then to decrease the groundwater discharge into it, and to increase the groundwater table thereafter increasing the depth of the seawater-fresh water interface.

> Doing and intensive geological, geotechnical and geophysical investigations before establishing and constructing buildings or farmers along the shoreline of the Dead Sea.

$>$ Carry out a continuous simulation model, this model must be function properly for the steep topography of hillside watersheds, must be able to delineate Wadies and streams as it flows down slope, model have a possibility for dams simulation because dams are considered essential in water management in Jordan, and this model should have relatively low data requirements due to few data are available for the Dead Sea hillside watershed.

Doing the radon-222 measurements and radium-223 at different months in the year at least two months in summer time and two months in wintertime to correlate the difference in radon-222 concentrations and to estimate the mixing rate of the Dead Sea layers.

Drilling some production wells at the distance about $1 \mathrm{~km}$ to the east and along the Dead Sea in order to pump and use the fresh water before reaching the Dead Sea. 


\section{REFERENCES}

Abraham, D., Charette M., Allen M., Rago A. and Kroeger, K. (2003): Radiochemical estimates of submarine groundwater discharge to Waquoit Bay, Massachusetts, Biol. Bull. 205: pp. 246-247.

Abu-Jaber, N. and Wafa, N. (1996): Hydrochemistry of aquifers in the southern Dead Sea, Southern Jordan. Environmental Geology 28: pp. 213-222.

Abu Ajamieh, M. (1980): The Geothermal Resources of Zarka Mai'n and Zara. Natural Resources Authority (NRA)/ Amman-Jordan.

Anati D. (1998): Dead Sea water trajectories in the T-S space, Hydrobiologia 381: pp. 43-49.

Anati, D. and Shasha S., (1989): Dead Sea surface-level changes. Israel J. Earth Sci. 38: pp. 29-32.

Anati, D., Gavrieli, L. and Oren, A. (1995): The residual effect of the 1991-1993 rainy winters on the Dead Sea stratification. Isr. J. Eart Sci. 44: pp. 63-70.

Arab Potash Company (APC): open files of the Arab Potash Company/JordanAmman.

Asmar, B., Ergenzinger, P., (1999): Estimation of evaporation from the Dead Sea, Hydrological processes 13: pp. 2743-2750.

Atalla, M. (1981): Geology and Structure of the area east of the Dead Sea. Master thesis. University of Jordan.

Bahat, D., Rabinovitch A., Frid, V., (2005): Tensile Fracturing in Rocks Tectonofractographic and Electromagnetic Radiation Methods.- Springer Berlin Heidelberg: pp. 569.

Ballestero, T., Roseen, R., Brannaka, L. (2004): Inflow and loadings from groundwater to the Great Bay Estuary, New Hampshire, Final Report Summitted to the NOAA/UNH cooperative Insittute for Coastal and Estuarine Environmental Technology (CICEET).

Bandel, K. And Khoury, H. (1981): Lithostratigraphy of the triasic in Jordan. Facies $4: 1-26$, Erlangen.

Barberi, G. and others, (1980): Recent basaltic volcanism of Jordan and its implications on the geodynamic history of the Dead Sea Shear Zone. Acc. Nat. DeiLicei, 47: pp. 667-673.

Baskin, R., (1990): Determination of ground-water inflow locations in Great Salt Lake, Utah, using the thermal infrared multispectral scanner, Master Thesis, The University of Utah.

Bender, F. (1968): Geologie von Jordanien, Bieter. Regionalen geologie Erde, Vol.7: pp. 230, Berlin Gebruder Brontraeger.

Bender, F. (1974). Gology of Jordan. Berlin: Borntraeger. 
Benoit, J., Torgersen, T., and O'Donnel, J., (1991): An advection/diffusion model for Rn-222 transport in near-shore sediments inhabited by sedentary polychaetes. Earth and Planetary Science Letters 105: pp. 463-473.

Beyth, M., Gavrieli I., Anati D., Katz O. (1993): Effects of the December 1991- May 1992 floods on the Dead Sea vertical structure. Israel Journal of Earth Sciences 41: pp. 45- 48.

Blake, G., (1936): The stratigraphy of Palestine and its building stones. Printing and stationary office, Jerusalem: pp. 133.

Bokuniewicz, H., Buddemeier, R., Maxwell, B., Smith, C., (2003): The typological approach to submarine groundwater discharge (SGD), Biogeochemistry 11, vol. 66 (1-2): pp.145-158.

Borisenko, L.S. (2001): Hydrogeological conditions of submarine groundwater discharge in the Crimea; Water resources 28 (1): pp. 15-21.

Broeker, W., Cromwell, J., and Li, Y., (1968): Earth Planet. Sci. Lett., 5: pp. 101

Bugna, G. C., Chanton, J.P., Cacble, J. E., Burnett, W. C., and Cable, P. H., (1996): The importance of groundwater discharge to the methane budgets of nearshore and continental shelf waters of the northeastern Gulf of Mesico. Geochimical Cosmochim. Acta 60: pp. 4735- 4746.

Burdon, D., (1959): Handbook of the geology of Jordan: to accompany and explain the three sheets of 1:250,000 geological map east of the rift, by A.M. Quennel Govt. Hashemite Kingdom of Jordan 82 pp. Benham, Colchester.

Burdon, D. and Papakis, N., (1961): Methods of investigating the groundwater resources of the parnassos- Ghiona Limestones. In: Groundwater in Arid Zones, 1- Symp. Int. Association Sciences Hydrol., Athens, 10-18 Sept. 1961, A.I.H.S., Gentbrugge, Publ. 56: pp. 143-159.

Burnett, W., Cable, J., Corbett, D. \& Chanton, J., (1996): Tracing groundwater flow into surface waters using natural Rn-222. Proc of Int. Symp. On Groundwater Discharge in the coastal Zone, Land-Ocean Interactions in the Coastal Zone (LOICZ), Moscow, July 6-10: pp. 22-28.

Burnett, W., Cable, J., and Corbett, D., (2003): Radon Tracing of Submarine Groundwater Discharge in Coastal Environments. Land and Marine Hydrogeology Elsevier B.V., Edited by Taniguchi M., Wang K. and Gamo T.: pp. 25- 43.

Burnet, W., Chanton, J., Christoff, J., Kontar, E., Kruba, S., Lambert, M., Moore, W., O'Rourke, D., Paulsen, R., Smith, C., Smith, L., \& Taniguchi, M., (2002): Assessing methodologies for measuring groundwater discharge to the ocean, EOC 83: pp. 117-123. 
Burnett, W., Henry, B., Huettel, M., Moore, W., and Taniguchi, M., (2003): Groundwater and pore water inputs to the coastal zone, Biogeochemistry 66: pp. 3-33.

Burnett, W, and Dulaiova, H., (2003): Estimating the dynamics of groundwater input into the coastal zone via continuous radon-222 measurements, Journal of Environmental Radioactivity 69: pp. 21-35.

Burnett, W.; Kim, G.; Lane-Smith, D. (2001): A continuous monitor for assessment of Rn-222 in the coastal ocean, Journal of Radio analytical and Nuclear Chemistry 249(1): pp. 167-172.

Burnett, W., Taniguchi, M. \& Oberdorfer, J, (2001): Measurement and significance of the direct discharge of groundwater into the coastal zone. Journal Sea Research 46: pp. 109-116.

Cable, J., Bugna, G., Burnett, W. \& Chanton, J. (1996a): Application of Rn-222 and $\mathrm{CH} 4$ for assessment of groundwater discharge to the coastal ocean. Limnology Oceanography 41: pp. 1347-1353.

Cable, J., Burnett, W. and Chanton, J. (1997): Magnitude and variations of groundwater seepage along a Florida marine shoreline. Biogeochemistry 38: pp. 189-205.

Cable, J, Burnett, W., Chanton, J., Weatherly, G., (1996b): Estimating groundwater discharge into the northern Gulf of Mexico using radon-222; Earth and planetry Science Letters 144: pp. 591-604

Capaccioni, B., Vaselli, O, Moretti, E., Tassi, F., and Franchi, R. (2003): The origin of thermal waters from the eastern flank of the Dead Sea Rift Valley (western Jordan). Blackwell Publishing Ltd. Terra Nova 15: pp. 145-154.

Capone, D. and Bautista, M. (1985): A groundwater source of nitrate in nearshore marine sediments. Nature 313: pp. 214-216

Charette, M. and Buesseler, K. (2004): Submarine groundwater discharge of nutrients and copper to an urban subestuary of Chesapeake Bay (Elizabeth River), Limnol. Oceanogr. 49 (2): pp. 376-385.

Charette, M., Buesseler, K., Andrews, J. (2001): Utility of radium isotopes for evaluating the input and transport of groundwater- derived nitrogen to a Cape Cod Estuary. Limol. Oceanography 46: pp. 465-470.

Charetta, M., Splivallo, R., Herbold, C., Bollinger, M., and Moore, W. (2003): Salt marsh submarine groundwater discharge as traced by radium isotopes; Marine Chemistry 84: pp. $113-121$.

Chanton, J.P., Burnett W.C., Dulaiova H., Corbett D.R., Taniguchi M., (2003), Seepage rate variability in Florida Bay driven by Atlantic tidal height, Biogeochemistry 11, 66 (1-2): pp. 187-202.

Church, TM. (1996): An underground route for the water cycle. Nature 380: pp. $579-580$. 
Corbett, D.R., Burnett,W.C., Cable.H.P., Clark, B.S. (1997): Radon tracing of groundwater input into Par Pond, Savannah River Site, Journal of Hydrology 203: pp. 209-227.

Corbett, D., Burnett, W., Cable, P. \& Clark S. (1998): A multiple approach to the determination of radon fluxes from sediments. Journal Radioanaly. Nucl. Chem. 236: pp. 247-252.

Corbet, D., Chanton, J., Burnett, W., Dillon, K., and Rutkowski, C. (1999): Patterns of groundwater discharge into Florida Bay, the American Society of Limonol. Oceanogr., 44(4): pp. 1045-1055.

Corbett, D., Dillon, K., Burnett, W. \& Chanton, J. (2000): Estimating the groundwater contribution into Florida Bay via natural tracers Rn-222 and $\mathrm{CH} 4$. Limonology Oceanography 45: pp. 1546-1557

Closson, D. (2005): Structural control of sinkholes and subsidence hazards along the Jordanian Dead Sea Coast. Environmental Geology 47: pp. 290-301.

Closson, D., Abou Karaki, N., Klinger, Y. and Hussein, M. (2005): Subsidence and Sinkholes Hazards Assessment in the southern Dead Sea Area, Jordan.Pure appl. Geophys 162: pp. 221-248.

Crusius, J., Koopmans, D., Bratton, J., Charette, M., Kroeger, K., Henderson, P., Ryckman L., Halloran, K., and Colman, J. (2005): Submarine groundwater discharge to a small estuary estimated from radon and salinity measurements and box model. Biogeosciences 2: pp. 141-157.

D'Elia, C. Webb, K. And Poter, J. (1981): Nitrate- rich groundwater inputs to discovery Bay, Jamaica: A significant source of $\mathrm{N}$ to local reefs, Bull. Mar. Sci. 31: pp. 903-910.

Destouni, G., Prieto, C. (2003): On the possibility for generic modelling of submarine groundwater discharge, Biogeochemistry 11, vol. 66 (1-2): pp. 171-186.

Duffield, W., Edwin, A., McKee, H., Salem, F., and Teimeh, M. (1987): K-AR ages, chemical composition, and geothermal significance of Cenozoic Basalt near the Jordan Rift, technical report, NRA, Amman.

Dulaiova, H., Burnett, C., Chanton, J., Moore, W., Bokuniewicz, H., Charette, M., and Scholkovitz, E. (2004): Continental Shelf Research report-USA.

Elhatip, H. (2003): The use of hydrochemical techniques to estimate the discharge of Ovac1k submarine springs on the Mediterranean coast of Turkey. Environmental Geology 43: pp. 714-719.

Erica, L., Hmmack R., Harbert W., Sams J., Veloski G. and Ackman T. (2005): Using airborne thermal infrared imagery and helicopter EM conductivity to locate mine pools and discharges in the Kettle Creek watershed, northcentral Pennsylvania, Geophysics 70 (6): pp. 73-81. 
Feruson, H., (1981). Water balance equations of lakes and reservoirs In ed. H.L. Ferguson and V.A. Znamensky, Methods of Computation of the water Balance of Large Lakes and Reservoirs, United Nations Educational, Scientific and Cultural Organization: pp. 19-24.

Freund, R., Goldberg, M., Weissbrod,T., Druckman,Y. and Drin, B. (1975): The Triassic-Jurassic structure of Israel and its relation to the origin of Eastern Mediterranean, Geology survey of Israel Bull. No. 65: pp. 1-26, Jerusalem

Gavrieli, I. (1997): Halite deposition from the Dead Sea: 1960-1993, in the Dead Sea the lake and its setting, Edited by Niemi T., Avraham Zvi and Gat, J., Oxford University Press, Oxford an New York: pp. 145-170.

Gavrieli, I., Bein, A., Oren, A. (2005): The expected impact of the peace conduit project (The Red Sea - Dead Sea pipeline) on the Dead Sea. Mitigation and Adaptation strategies for Global Change 10: pp. 3-22

Gavrieli, I. and Oren, A. (2004): The Dead Sea as a dying lake. Dying and Dead Seas, Earth and Environmental Sciences 36: pp. 287-305.

Gavrieli, I., Starinsky, A., and Bein, A. (1989): The solubility of the halite as a function of Temperature in the highly saline Dead Sea brine system. Limnol. Oceanography 34: pp. 1224-1232.

German Technical Assistant (GTZ), (1995): Groundwater modelling in Jordan- A Review and Ground Water Information System of Jordan, Amman, Jordan and Atlanta, USA.

Getman, I., Hecht, A. (2002): The Dead Sea hydrography from 1992 to 2000, Journal of Marine System 35: pp. 169-181.

Hunting and Macdonald, M. and Partners, (1965) East bank water resources. Hydrogeological survey of the Madaba-Ma'in area. Vol. 1-3. Central Water Authority, Hashemite Kingdom of Jordan.

Itmar, A., and Reizmann, Y. (2000): Air photo survey of sinkholes in the Dead Sea area. Curr. Res. 12 : pp. 21-24.

Jahne, B. Munnich, K.O., Bosinger, R., Dutzi, A., Huber, W., Libner, P. (1987): On the parameters influencing air-water gas exchange. J. Geophysics Res. 92: pp.1937-1950

Jiries, A. El-Alali, A. (1996): Groundwater effect on salt reef growth in the southern Basin of the Dead Sea. Mu'tah Journal for research and studied 11 (1): pp. 97-109.

Kay, J., Kampf, S., Handcock, R., Cherkauer K., Gillespie, A., and Burges J., (2005): Accuracy of lake and stream Temperatures estimated from thermal infrared Images.

Kelly, R. and Moran, S. (2002): Seasonal changes in groundwater input to a wellmixed estuary estimated using radium isotopes and implications for 
coastal nutrient budgets. Limnology and Oceanography 47(6): pp. 17961807.

Khdeir, K. (1997): An assessment of regional hydrogeological framework of the

Mesozoic aquifer system of Jordan. PhD thesis, University of Birmingham, UK.

Kim, G. and Hwang, W. (2002): Tidal pumping of groundwater into the coastal ocean revealed from submarine $\mathrm{Rn} 222$ and $\mathrm{CH} 4$ monitoring. Geophysical Research Letters 29(14): pp. 23-27.

Klein, C. (1961): On the fluctuations of the level of the Dead Sea since the beginning of the $19^{\text {th }}$ century. Hydrological paper no.7, Ministry of Agriculture, Hydrological Service of Israel.

Krest, J. and Harvey, J., (2003): Using natural distributions of short-lived radium isotopes to quantify groundwater discharge and recharge. Limnology and Oceanography 48(1): pp. 290-298.

Krumgalz, B. (1997): Ion interaction approach to geochemical aspects of the Dead Sea. in the Dead Sea the lake and its setting, Edited by Niemi T., Avraham Zvi and Gat, J., Oxford University Press, Oxford an New York: pp. 145-160.

Krumgalz, B., Hecht, A., Starinsky, A.and Katz, A., (2000): Thermodynamic constraints on Dead Sea evaporation: how much can the Dead Sea evaporate? Chemical Geology 165: pp. 1-11.

Lambert, M.J., Burnett, W.C., (2003): Submarine groundwater discharge estimates at a Florida coastal site based on continuous radon measurements, Biogeochemistry 11, vol. 66 (1-2): pp. 55-73.

Lee, D. (1977): A device for measuring seepage flux in lakes and estuaries. Limnology. Oceanography. 22: pp.140-147.

Loaiciga, H., Zektser, I. (2003): Estimation of Submarine Groundwater Discharge, Water Resources, Vol.30 (5): pp. 473-479.

Li, L., Bary, D., Stagnitti, F., Parlange, J. (1999): Submarine groundwater discharge and associated chemical input to a coastal sea. Water Resources Research 35: pp. 3253-3259.

Lloyd, J. (1969): The hydrogeology of the southern desert of Jordan. UNDP/FAO project 212. Tech. Rep. 1.

Mac Donald, Sir M. and Partners, (1965): East Bank water resources. Hydrogeological survey of the Madaba-Ma'an area. Vols 1-3. Central water Authority. Hashemite Kingdom of Jordan.

Macintyre, S., Wanninkhof, R., and Chanton, J. (1995): Trace gas exchange across the air sea interface in fresh water and coastal marine environments. In: P.A. Matson, R.C. Harriss (eds.) Biogenic Trace Gases: Measuring Emissions from Soil and Water, Blackwell Sciences Ltd. 52-97 
Manheim, F., Krantz, D., Snyder, D., Bratton, J., White, E., Madsen, J. (2001): Streaming resisitivity survey and core drilling define groundwater discharge into coastal bays of the Delmarva peninsula, The Geological Society of America (GSA).

Mathieu, G., Biscayne, P., Lupton, R. \& Hammond, D. (1988): System for measurements of Rn-222 at low levels in natural waters. Health Physics 55: pp. 989-992.

Martens, C. S., Kipphut, G.W., and Klump, J.V. (1980): Sediment-water chemical exchange in the coastal zone traced by in situ radon-222 flux measurements. Science, 208: pp. 285-288.

McBride, M.S., Pfannkuch, H.O. (1975): The distribution of seepage within lakebeds. US Geol. Surv. J. Res. 3: pp. 505-512.

Mckenna, T., Andres, A., Wang, L., and Deliberty, T. (2001): Mapping locations of ground-water discharge in rehoboth and Indian River bays, Delaware using thermal imagery, the geological society of America (GSA).

Ministry of Water and Irrigation (MWI) (1997): Open files. Amman, Jordan.

Mower, R. (1968): Groundwater discharge toward Great Salt Lake through valley fills in the Jordan Valley, Utah. Geol. Survey Res., U.S. Geological Survey Professional paper, 600-D: pp. 71-74.

Moore, W.S. (1976): Sampling Radium-228 in Deep Ocean; Deep-Sea Res. 23: pp. 647-651.

Moore, W.S. (1984): Radium Isotope Measurements Using Germanium Detectors, Nucl. Inst. Methods 223: pp. 407-411.

Moore, W.S., (1996): Large groundwater inputs to coastal waters revealed by Ra226 enrichments, Nature 380: pp. 612-614.

Moore, W.S. (1999): The subterranean estuary: a reaction zone of groundwater and sea water, Marine Chemistry 65: pp. 111-126.

Moore, W.S. (2000): Determining coastal mixing rates using radium isotopes. Continental Shelf Res. 20: pp. 1995-2007.

Moore, W.S., Key, R.M. and Samiento, J.L. (1985): Techniques for precise Mapping of Ra-226 and Ra-228 in the Ocean, J.Geophys. Res. 90: pp. 6983-6994.

Moore, W.S. (2003): Sources and fluxes of submarine groundwater discharge delineated by radium isotopes, Biogeochemistry11, vol. 66 (1-2): pp. 7593.

Moore, W.S. and Shaw, T.J. (1998): Chemical signals from submarine fluid advection onto the continental shelf, J. Geophys. Res. 103: pp. 2154321552. 
Mulligan, E. and Charette, M. (2006): Intercomparison of submarine groundwater discharge estimates from a sandy unconfined aquifer, Journal of Hydrology, in press.

Natural Resources Authority (NRA): Internal reports and geological maps sheets in Natural Resources Authority-Jordan/Amman.

Neev, D., Emery, K. (1967): The Dead Sea. Ministry of development, Geological survey, Israel Bulletin No. 41.

Neev, D. and Hall, J. (1976): The Dead Sea geophysical survey, 19 July-1August 1974-Final Report2: Geological survey of Israel, Marine Geology Division, Report No. 6/76: pp. 21.

Neev, D., Hall, J., (1979): Geophysical investigations in the Dead Sea. Sedimentary Geology 23: pp. 209-238.

Niemi, T. and Ben-Avraham, Z. (1997): The Dead Sea, The Lake and its setting. New Yourk, Oxford University press: pp. 73.

Oberdorfer, J. (2003): Hydrogeological modeling of submarine groundwater discharge: comparison to other quantitative methods. Biogeochemistry 66: pp. 159-169.

Obermeyer, H. (2005): Personal commencations, Gesellschaft fuer Erkundungortung, Karlsruhe-Germany.

Parker, D. H. (1970): The hydrogeology of the Mesozoic-Cainozoic aquifers of the wetern highlands and plateau of East Jordan. UNDP/FAO, AG2. SF/JOR9, Technical report No. 2, Rome.

Parnes, A. (1975): Middle Triassic ammonite biostratigraphy in Israel. Geological Survey of Israel Bulletin 66: pp.1-35.

Peng, T., Takahashi, T. and Broecker, W. (1974). Surface radon measurements in the North Pacific station Pape. Journal of Geophysics Res. 79 (12): pp. 1772-1780.

Pluhowski, E. and Kantrowitz, I. (1964): Hydrology of the Babylon-slip area, Suffolk County, Long Island, New York. US Geological survey water-Supply, 1768: pp. 120.

Powell, J. (1988): The geology of the Karak area. Bull. 8, Geol. Mapping Div., Geol. Dir., Natural Resources Authority, Jordan.

Powel, J. (1989): Stratigraphy and Sedimention of Phanerozoic Rocks in Central and South Jordan. Part B Kurnub, Ajlun and Belqa Group. Bulletin 11B, NRA, Amman.

Quennell, A.M. (1951): The geology and mineral resources of former Transjordan. Colon. Geol. Min. Resources, 2.

Quennell, A.M. (1959): Tectonics of the Dead Sea rift. Inter. Geol. Cong. $20^{\text {th }}$, Assoc. African Geol. Surv.: pp. 385-405. 
Rama, M. and Moore, W.S. (1996): Using the radium quartet for evaluating groundwater input and water exchange in salt marches, Geochim. Cosmochim acta 60: pp. 4645-4652.

Rishmawi K., Eagleton N., Harimat N., and Isaac J. (2005): Using medium-high spatial resolution Sattellite data to monitor biomass changes in the Dead Sea Basin. International Conference on : promotion community-driven conservative and sustainable use of Dry land Argo biodiversity, Syria 1821 April.

Rundquist, D., Murray, G., Queen, L. (1985): Airborne thermal mapping of a "flowthrough" lake in the Nebraska Sand Hills, Water Resources Bulletin 216 (6): pp.989-994.

Salameh, E. (1996): Water quality in Jordan (impacts on environments and future generations resources base). Friedrich Ebert Stiftung, Royal Society for the conservation of nature.

Salameh, E., (1996): Water quality degradation in Jordan (impacts on environment, economy and future generations resources base). National library.

Salameh, E. and Bannayan, H. (1993): Water resources of Jordan present status and future potentials. Friedrich Ebert Stiftung- Amman.

Salameh, E. and El-Naser, H. (1999): Does the actual drop in Dead Sea level reflect the development of water sources within its drainage basin, Acta hydrochim. Hydrobiol. 27: pp. 5-11.

Salameh, E. and El-Naser, H. (2000a): Changes in the Dead Sea level and their impact on the surrounding Groundwater bodies, Acta hydrochim. Hydrobiol. 28: pp. 24-33.

Salameh, E. and El-Naser, H., (2000b): The interface configuration of the fresh /Dead Sea water-Theory and measurements, Acta hydrochim. Hydrobiol. 28: pp. 323-328.

Salameh, E., and Khawaj, M. (1984): The Mediterranean Dead Sea Canal and its environmental impacts, WRSC Bull, $2^{\text {nd }}$ Issue, University of Jourdan, Amman.

Salameh, E. and Rimawi, O. (1988): The special features of the groundwater flow system in central Jordan. Dirasat 9, University of Jordan, Amman: pp. 3858.

Salameh, E., and Udluft, P. (1985): The hydrodynamic pattern of central Jordan, Geol. Jb, c38, Hannover.

Schneider, R. L., Negley, T.L., Wafer, C., (2005): Factors influencing groundwater seepage in a large, mesotrophic lake in New York, J. of Hydrology 310: pp. 1-16. 
Schwartz, (2003): Significant groundwater input to a coastal plain estuary: assessment from excess Radon; Eatuarine, Coastal and Shelf Science 56: pp. 31-42.

Senior, L., Vogel, K., (1995): Radium and Radon in groundwater in the Chickies quartzite, southern eastern Pennsylvania. US Geological survey waterresources Investigation Report, 92-4088: pp. 15.

Shaban, A., Khawlie, M., Abdallah, C., Faour, G. (2005): Geologic controls of submarine groundwater discharge: application of remote sensing to north Lebanon. Environ. Geol. 47, pp. 512-522.

Shawabekeh, K. (1998): The Geology of Mai'n Area, Map sheet No. (3153 III). Natural Resources Authority-Amman (Internal Report).

Smith A.J., Nield S.P, (2003): Groundwater discharge from the superficial aquifer into Cockburn Sound Western Australia, estimation by inshore water balance, Biogeochemistry 11, 66 (1-2): pp. 125-144.

Smith, L., Zawadzki W. (2003): A hydrogeological model of submarine groundwater discharge; Florida inter comparison experiment, Biogeochemistry 11, 66, (1-2): pp. 95-110.

Steinhorn, I. (1983): In situ salt precipitation at the Dead Sea. Limnol. Oceanogr. 28: pp. 580-583.

Steinhorn, I. and Gat, J. R. (1983): The Dead Sea, Scientific Am. 149: pp. 102-109.

Steinhorn, I., (1985): The disappearance of the long-term meromictic stratification of the Dead Sea. Limnology and Oceanography 30: pp. 451-472.

Stiller, M., Chung, Y. (1984): Radium in the Dead Sea: A possible tracer for the duration of meromixis. Limnology and Oceanography 29(3): pp. 574-586.

Swarzenski W., Jonathan M., and Cable C. (2001): Submarine ground-water discharge in upper Indian River Lagoon, Florida, U.S. Geological Survey Karst Interest Group Proceedings, Water-Resources Investigations Report 01-4011: pp. 194-197.

Taniguchi, M., Burnett, W., Cable, E., Turner, J. (2002): Investigation of submarine groundwater discharge, Hydrological processes 16: pp.2115-2129.

Taniguchi, M., Burnett W.C., Smith C.F., Paulsen R.J., O'Rourke D., Kruba S.L., Christoff J.L. (2003): Spatial and Toral distributions of submarine groundwater discharge rates obtained from various types of seepage meters at the site in the north eastern gulf of Mexico, Biogeochemistry 11, 66 (1-2): pp. 35-53.

Taqieddin, S., Abderahman, N. and Attalah, M. (2000): Sinkholes Hazards along the Eastern Dead Sea Shoreline Area, Jordan. A Geological and Geotechnical Consideration, Environ. Geology 39 (11): pp. 1237-1253. 
Tcherepanov, E.N., and Zlotnik, V. (2002): Applications of remote sensing for hydrological studies in the Nebraska, Report for NE9B, in GSA Abstracts with program, Denver, Colorado: pp. 88.

Valiela, I., Costa J., Foreman, K., Teal, J., Howes, B., and Aubrey, D. (1990): Transport of groundwater borne nutrients from watersheds and their effects on coastal waters. Biogeochemistry 10: pp. 177-198.

Valiela, I \& D'Elia, C. (1990): Groundwater inputs to coastal waters. Special Issue Biogeochemistry 10: pp. 328.

Vsevolozhskii, V. and Kochetkova, R. (2003): Groundwater runoff in Karelia, Water Resources 30 (4): pp. 351-360.

Ullman, W. and Aller, R. (1981): Diffusion coefficients in nearshore marine sediments. Limnology Oceanography 27: pp. 552-556

US geological survey Bulletin (1971): pp. 195-225.

Water Authority of Jordan (WAJ): Open files of the Water Authority of Jordan/Amman.

Wanninkhof, R., (1992): Relationship between wind speed and gas exchange over the ocean. Journal Geophysics Research 97: pp. 7373-7382.

Water Data Banks Project, Multilateral Working Group on Water Resources, Middle East Peace Process. http://exact-me.org/overview/p17.htm.

Wiesemann, G. (1969): Zur Tektonik des Gebietes Ostlich des Grabeabschnittes Totes Meer-Jordantal. Beih. Geol. Jb., 81 Hannover.

Yechieli, Y., Ronen, D., Kaufman, A. (1996): The source and age of groundwater brines in the Dead Sea area as deduced from $\mathrm{Cl} 36$ and C14. Geochimica et cosmochimica Acta, 60 (11): pp. 1909-1916.

Zektser, I., Dzhamalov, R., Safronova, T. (1983): Role of submarine groundwater discharge in the water balance of Australia. IAHS-AISH publication, No. 142 'Groundwater in Resources Planning': pp. 209-219. 


\section{APPENDICES}




\section{APPENDIX I}

Photos for The Thermal Infrared Camera and The Plane which Used for Carring out TIR Imagery 


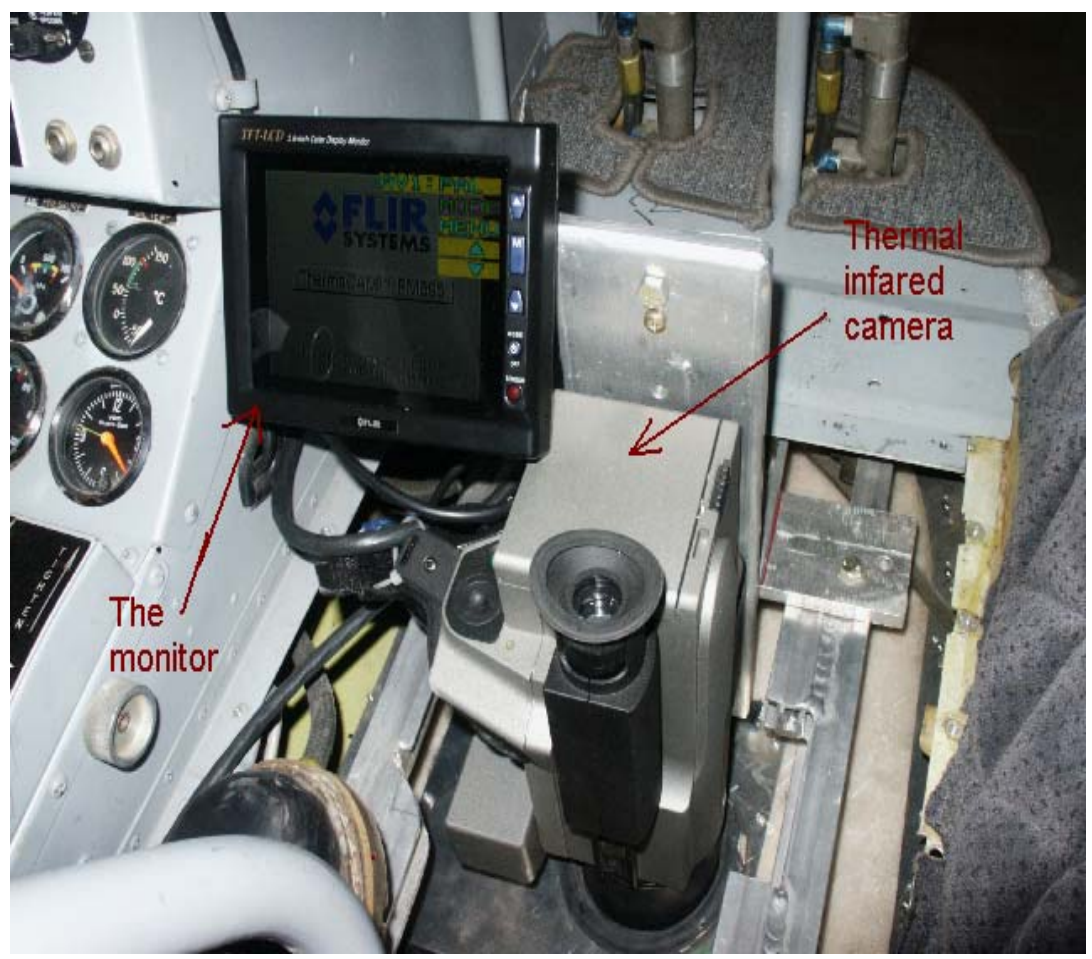

Photo1: the thermal infrared camera fixed inside the plane.

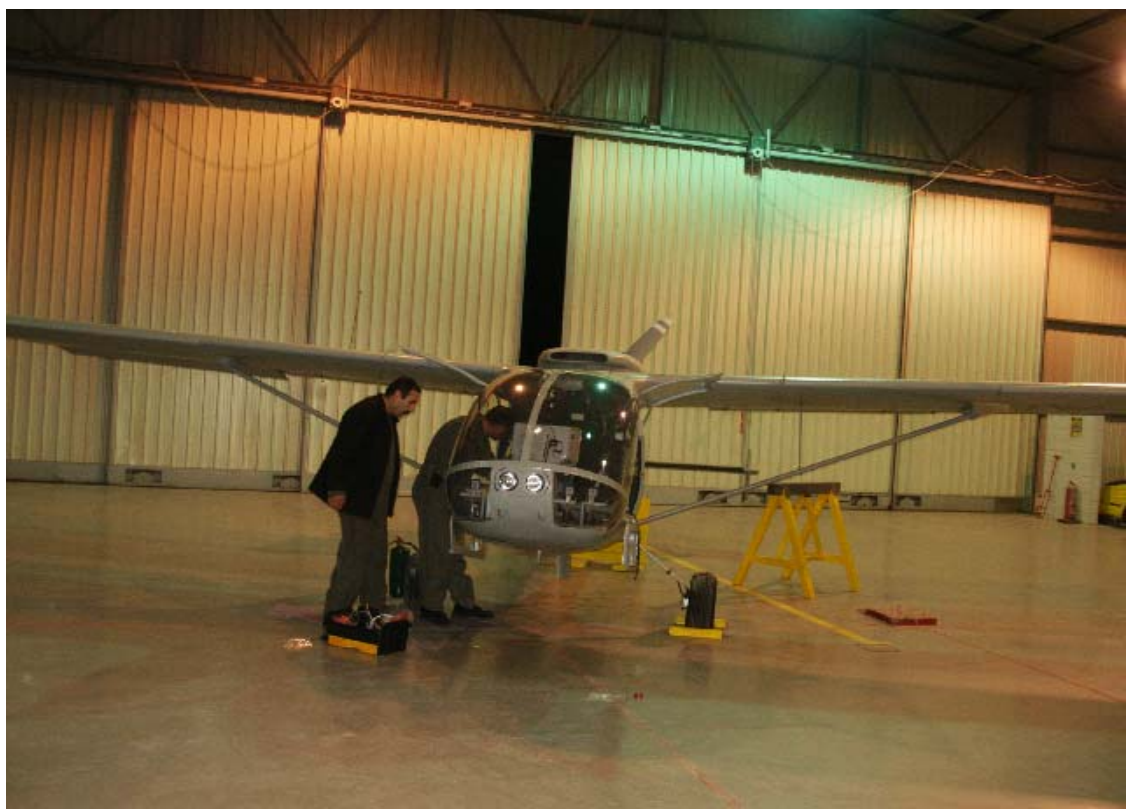

Photo 2: commercial plane which was used for TIR imagery 


\section{APPENDIX II}

The Electrical Conductivity, Temperature, Total Dissolved Solids and The Depth Data for Sweimeh area, Zarka Ma'in, Zara and Mujeb Area. 
Zarka ma'in $100 \mathrm{~m}$ away from the shoreline

\begin{tabular}{|c|c|c|c|c|c|c|c|}
\hline $\begin{array}{c}\text { Depth } \\
{[\mathrm{m}]}\end{array}$ & $\begin{array}{c}\text { E.C. } \\
{[\mathrm{mS} / \mathrm{cm}]}\end{array}$ & $\begin{array}{c}\mathrm{T} . \\
{\left[\mathrm{C}^{\circ}\right]}\end{array}$ & $\begin{array}{c}\mathrm{TDS} \\
{[\mathrm{g} / \mathrm{l}]}\end{array}$ & $\begin{array}{c}\text { Depth } \\
\text { [m] }\end{array}$ & $\begin{array}{c}\text { E.C. } \\
{[\mathrm{mS} / \mathrm{cm}]}\end{array}$ & $\begin{array}{c}\mathrm{T} . \\
{\left[\mathrm{C}^{\circ}\right]}\end{array}$ & $\begin{array}{c}\mathrm{TDS} \\
{[\mathrm{g} / \mathrm{l}]}\end{array}$ \\
\hline 1 & 176.05 & 38.48 & 403.241839 & 47 & 186.56 & 24.79 & 366.137489 \\
\hline 2 & 176.53 & 38.27 & 401.769508 & 48 & 186.73 & 24.75 & 365.42282 \\
\hline 3 & 176.6 & 38.07 & 401.55345 & 49 & 186.79 & 24.73 & 365.169346 \\
\hline 4 & 176.69 & 37.88 & 401.275152 & 50 & 186.87 & 24.71 & 364.830362 \\
\hline 5 & 176.47 & 37.7 & 401.954426 & 51 & 186.88 & 24.7 & 364.787907 \\
\hline 6 & 176.46 & 37.53 & 401.985221 & 52 & 186.93 & 24.69 & 364.575354 \\
\hline 7 & 177.3 & 37.36 & 399.373528 & 53 & 186.99 & 24.68 & 364.319681 \\
\hline 8 & 178.46 & 37.19 & 395.680017 & 54 & 186.99 & 24.67 & 364.319681 \\
\hline 9 & 179.14 & 37.02 & 393.464844 & 55 & 187.05 & 24.65 & 364.063336 \\
\hline 10 & 179.88 & 36.86 & 391.009383 & 56 & 187.13 & 24.64 & 363.720489 \\
\hline 11 & 180.1 & 36.71 & 390.269975 & 57 & 187.18 & 24.63 & 363.505594 \\
\hline 12 & 180.88 & 36.64 & 387.612017 & 58 & 187.21 & 24.61 & 363.376427 \\
\hline 13 & 181.47 & 36.24 & 385.562046 & 59 & 187.29 & 24.59 & 363.031137 \\
\hline 14 & 181.47 & 35.45 & 385.562046 & 60 & 187.38 & 24.58 & 362.6412 \\
\hline 15 & 180.41 & 35.39 & 389.22051 & 61 & 187.27 & 24.58 & 363.117575 \\
\hline 16 & 180.1 & 34.75 & 390.269975 & 62 & 187.48 & 24.55 & 362.206071 \\
\hline 17 & 180.71 & 34.69 & 388.19627 & 63 & 187.46 & 24.54 & 362.293255 \\
\hline 18 & 180.08 & 34.44 & 390.337376 & 64 & 187.57 & 24.53 & 361.812753 \\
\hline 19 & 176.99 & 34.19 & 400.343308 & 65 & 187.56 & 24.52 & 361.856535 \\
\hline 20 & 178.9 & 33.99 & 394.251061 & 66 & 187.61 & 24.51 & 361.637422 \\
\hline 21 & 177.49 & 33.7 & 398.775628 & 67 & 187.2 & 24.5 & 363.419502 \\
\hline 22 & 174.52 & 33.42 & 407.832448 & 68 & 187.4 & 24.49 & 362.554332 \\
\hline 23 & 169.99 & 33.19 & 420.623731 & 69 & 187.7 & 24.48 & 361.24174 \\
\hline 24 & 166.53 & 32.32 & 429.719146 & 70 & 187.4 & 24.47 & 362.554332 \\
\hline 25 & 166.03 & 31.93 & 430.991886 & 71 & 187.7 & 24.46 & 361.24174 \\
\hline 26 & 167.44 & 31.35 & 427.376896 & 72 & 187.8 & 24.46 & 360.800142 \\
\hline 27 & 167.59 & 30.77 & 426.987526 & 73 & 187.7 & 24.45 & 361.24174 \\
\hline 28 & 168.51 & 30.34 & 424.578386 & 74 & 187.7 & 24.44 & 361.24174 \\
\hline 29 & 170.14 & 29.76 & 420.217237 & 75 & 187.9 & 24.43 & 360.356462 \\
\hline 30 & 171.61 & 29.23 & 416.175121 & 76 & 187.9 & 24.42 & 360.356462 \\
\hline 31 & 172.32 & 28.87 & 414.183144 & 77 & 187.9 & 24.42 & 360.356462 \\
\hline 32 & 173.7 & 28.41 & 410.23237 & 78 & 187.7 & 24.41 & 361.24174 \\
\hline 33 & 174.85 & 28.08 & 406.855032 & 79 & 187.6 & 24.41 & 361.681285 \\
\hline 34 & 176.17 & 27.68 & 402.875249 & 80 & 188 & 24.4 & 359.910672 \\
\hline 35 & 177.36 & 27.33 & 399.185009 & & & & \\
\hline 36 & 179.06 & 26.78 & 393.727457 & & & & \\
\hline 37 & 180.11 & 26.29 & 390.23626 & & & & \\
\hline 38 & 181.15 & 25.87 & 386.67824 & & & & \\
\hline 39 & 181.99 & 25.67 & 383.725531 & & & & \\
\hline 40 & 182.62 & 25.49 & 381.461169 & & & & \\
\hline 41 & 182.89 & 25.38 & 380.476938 & & & & \\
\hline 42 & 183.48 & 25.22 & 378.296014 & & & & \\
\hline 43 & 183.96 & 25.09 & 376.489757 & & & & \\
\hline 44 & 184.2 & 25 & 375.575395 & & & & \\
\hline 45 & 185.39 & 24.9 & 370.923294 & & & & \\
\hline 46 & 186.23 & 24.83 & 367.51033 & & & & \\
\hline
\end{tabular}


Zarka Ma'in $200 \mathrm{~m}$ away from the shoreline

\begin{tabular}{|c|c|c|c|c|c|c|c|}
\hline $\begin{array}{c}\text { Depth } \\
\text { [m] }\end{array}$ & $\begin{array}{c}\text { E.C. } \\
{[\mathrm{mS} / \mathrm{cm}]}\end{array}$ & $\begin{array}{c}\mathrm{T} . \\
{\left[\mathrm{C}^{\circ}\right]}\end{array}$ & $\begin{array}{c}\mathrm{TDS} \\
{[\mathrm{g} / /]}\end{array}$ & $\begin{array}{c}\text { Depth } \\
{[\mathrm{m}]}\end{array}$ & $\begin{array}{c}\text { E.C. } \\
{[\mathrm{mS} / \mathrm{cm}]}\end{array}$ & $\begin{array}{c}\text { T. } \\
{\left[\mathrm{C}^{\circ}\right]}\end{array}$ & $\begin{array}{c}\text { TDS } \\
{[g / l]}\end{array}$ \\
\hline 1 & 192.03 & 33.74 & 339.715357 & 51 & 179.14 & 26.75 & 393.464844 \\
\hline 2 & 191.9 & 33.8 & 340.453145 & 52 & 179.66 & 26.6 & 391.74442 \\
\hline 3 & 190 & 34.03 & 350.498509 & 53 & 179.91 & 26.45 & 390.908814 \\
\hline 4 & 188.98 & 34.13 & 355.423513 & 54 & 179.19 & 26.37 & 393.300434 \\
\hline 5 & 187.52 & 34.14 & 362.031463 & 55 & 179.69 & 26.22 & 391.644442 \\
\hline 6 & 185.77 & 34.1 & 369.393381 & 56 & 180.22 & 26.08 & 389.864791 \\
\hline 7 & 185.18 & 34.03 & 371.759218 & 57 & 180.75 & 25.95 & 388.059052 \\
\hline 8 & 185.64 & 33.9 & 369.919323 & 58 & 181.2 & 25.83 & 386.50452 \\
\hline 9 & 185.78 & 33.81 & 369.352812 & 60 & 181.47 & 25.77 & 385.562046 \\
\hline & & & & 61 & 181.92 & 25.66 & 383.974429 \\
\hline 10 & 185.42 & 33.79 & 370.803329 & 62 & 182.38 & 25.56 & 382.32901 \\
\hline 11 & 184.97 & 33.75 & 372.588546 & 63 & 182.73 & 25.47 & 381.061208 \\
\hline 12 & 184.05 & 33.71 & 376.147766 & 64 & 183.07 & 25.38 & 379.816027 \\
\hline 13 & 183.78 & 33.67 & 377.170563 & 65 & 183.35 & 25.3 & 378.7802 \\
\hline 14 & 183.97 & 33.58 & 376.45181 & 66 & 183.49 & 25.27 & 378.258682 \\
\hline 15 & 184.06 & 33.52 & 376.109701 & & & & \\
\hline 16 & 183.19 & 33.46 & 379.373267 & 68 & 183.8 & 25.19 & 377.095125 \\
\hline 17 & 182.02 & 33.4 & 383.618699 & 70 & 184.09 & 25.11 & 375.995427 \\
\hline 18 & 179.84 & 33.25 & 391.143349 & 71 & 184.07 & 25.04 & 376.071623 \\
\hline 19 & 178.4 & 33.1 & 395.87365 & 72 & 184.23 & 24.97 & 375.460559 \\
\hline 20 & 175.13 & 32.99 & 406.020333 & 73 & 184.35 & 24.94 & 375 \\
\hline 21 & 171.15 & 32.86 & 417.45165 & 74 & 184.58 & 24.88 & 374.111743 \\
\hline 22 & 167.77 & 32.7 & 426.519029 & 75 & 184.86 & 24.81 & 373.020374 \\
\hline 23 & 165.87 & 32.38 & 431.397086 & 77 & 185.13 & 24.75 & 371.95727 \\
\hline 24 & 166.63 & 32.12 & 429.463404 & 80 & 185.54 & 24.65 & 370.322079 \\
\hline 25 & 167.1 & 31.83 & 428.255995 & 81 & 185.88 & 24.57 & 368.94624 \\
\hline 26 & 166.58 & 31.24 & 429.591325 & 82 & 186.11 & 24.48 & 368.004934 \\
\hline 27 & 167.15 & 30.94 & 428.127016 & 83 & 186.27 & 24.41 & 367.344922 \\
\hline 28 & 168.24 & 30.47 & 425.28921 & 84 & 186.53 & 24.34 & 366.263074 \\
\hline 29 & 169.73 & 30.17 & 421.32579 & 85 & 186.67 & 24.31 & 365.675645 \\
\hline 30 & 169.27 & 29.89 & 422.560149 & 86 & 186.77 & 24.27 & 365.253909 \\
\hline 31 & 171.24 & 29.61 & 417.202746 & 87 & 186.84 & 24.24 & 364.957618 \\
\hline 32 & 170.59 & 29.47 & 418.991247 & 88 & 187.04 & 24.19 & 364.106107 \\
\hline 33 & 170.04 & 29.22 & 420.488353 & 90 & 187.24 & 24.14 & 363.247088 \\
\hline 34 & 171.78 & 28.97 & 415.700593 & 91 & 187.46 & 24.08 & 362.293255 \\
\hline 35 & 172.86 & 28.73 & 412.649923 & & & & \\
\hline 36 & 173.52 & 28.5 & 410.753832 & & & & \\
\hline 38 & 174.27 & 28.28 & 408.568432 & & & & \\
\hline 40 & 174.61 & 28.16 & 407.566552 & & & & \\
\hline 41 & 175.2 & 27.95 & 405.810876 & & & & \\
\hline 42 & 175.78 & 27.75 & 404.063092 & & & & \\
\hline 43 & 176.41 & 27.56 & 402.139091 & & & & \\
\hline 44 & 177.09 & 27.37 & 400.031246 & & & & \\
\hline 45 & 177.69 & 27.18 & 398.143323 & & & & \\
\hline 47 & 177.96 & 27.09 & 397.284855 & & & & \\
\hline 50 & 178.52 & 26.93 & 395.486092 & & & & \\
\hline
\end{tabular}


Zarka Ma'in $400 \mathrm{~m}$ away from the shoreline

\begin{tabular}{|c|c|c|c|c|c|c|c|}
\hline $\begin{array}{l}\text { Depth } \\
{[\mathrm{m}]}\end{array}$ & \begin{tabular}{r|}
$\begin{array}{c}\text { E.C. } \\
{[\mathrm{mS} / \mathrm{cm}]}\end{array}$ \\
191.48 \\
\end{tabular} & $\begin{array}{l}\begin{array}{l}\mathrm{T} . \\
{\left[\mathrm{C}^{\circ}\right]}\end{array} \\
34.04 \\
\end{array}$ & \begin{tabular}{l|} 
TDS \\
{$[\mathrm{g} / \mathrm{l}]$}
\end{tabular} & $\begin{array}{c}\text { Depth } \\
{[\mathrm{m}]}\end{array}$ & $\begin{array}{c}\text { E.C. } \\
{[\mathrm{mS} / \mathrm{cm}]}\end{array}$ & $\begin{array}{c}\mathrm{T} . \\
{\left[\mathrm{C}^{\circ}\right]}\end{array}$ & $\begin{array}{l}\text { TDS } \\
{[\mathrm{g} / \mathrm{l}]}\end{array}$ \\
\hline 2 & 189.43 & 34.25 & 353.285243 & 56 & 179.73 & 26.58 & 391.511014 \\
\hline 3 & 187.32 & 34.29 & 362.901334 & 58 & 180.27 & 26.44 & 389.69557 \\
\hline 4 & 187.27 & 34.28 & 363.117575 & 60 & 180.79 & 26.29 & 387.921678 \\
\hline 5 & 187.44 & 34.24 & 362.38036 & 61 & 181.32 & 26.14 & 386.086561 \\
\hline 6 & 187.8 & 34.2 & 360.800142 & 62 & 181.79 & 26.01 & 384.435272 \\
\hline 7 & 186.26 & 34.17 & 367.3863 & 64 & 182.03 & 25.94 & 383.583066 \\
\hline 8 & 186.64 & 34.14 & 365.801816 & 66 & 182.47 & 25.82 & 382.004335 \\
\hline 9 & 186.3 & 34.12 & 367.220688 & 68 & 182.89 & 25.7 & 380.476938 \\
\hline 10 & 187.28 & 34.06 & 363.074366 & 70 & 183.33 & 25.59 & 378.854505 \\
\hline 11 & 185.59 & 34.04 & 370.120897 & 71 & 183.74 & 25.48 & 377.321284 \\
\hline 12 & 184.85 & 34 & 373.059544 & 72 & 183.97 & 25.42 & 376.45181 \\
\hline 13 & 184.79 & 33.83 & 373.294264 & 73 & 184.56 & 25.26 & 374.189274 \\
\hline 14 & 184.15 & 33.8 & 375.766519 & 74 & 184.74 & 25.21 & 373.489469 \\
\hline 15 & 179.46 & 33.57 & 392.408907 & 75 & 185.14 & 25.11 & 371.917689 \\
\hline 16 & 177.77 & 33.5 & 397.889547 & 76 & 185.55 & 25 & 370.281874 \\
\hline 17 & 177.73 & 33.41 & 398.016496 & 80 & 185.89 & 24.92 & 368.905494 \\
\hline 18 & 176.81 & 33.16 & 400.903191 & 81 & 186.06 & 24.88 & 368.210308 \\
\hline 19 & 172.46 & 33.02 & 413.787177 & 82 & 186.41 & 24.79 & 366.763842 \\
\hline 20 & 166.82 & 32.94 & 428.976384 & 83 & 186.66 & 24.72 & 365.71772 \\
\hline 21 & 165.37 & 32.76 & 432.656961 & 84 & 186.9 & 24.65 & 364.702941 \\
\hline 22 & 165.91 & 32.51 & 431.29588 & 85 & 187.17 & 24.58 & 363.548611 \\
\hline 23 & 164.77 & 32.23 & 434.156302 & 90 & 187.42 & 24.53 & 362.467386 \\
\hline 24 & 164.23 & 31.93 & 435.494324 & 91 & 187.57 & 24.49 & 361.812753 \\
\hline 25 & 163.85 & 31.78 & 436.429573 & 92 & 187.78 & 24.44 & 360.888627 \\
\hline 26 & 165.54 & 31.1 & 432.229679 & & & & \\
\hline
\end{tabular}

\begin{tabular}{|r|r|r|r|}
\hline 26 & 165.54 & 31.1 & 432.229679 \\
\hline 27 & 167 & 30.76 & 428.513645 \\
\hline 28 & 166.6 & 30.45 & 429.540169 \\
\hline 29 & 170.43 & 30.15 & 419.428282 \\
\hline
\end{tabular}

\begin{tabular}{|c|c|c|c|}
\hline 30 & 169.38 & 30 & 422.265867 \\
\hline 31 & 170.47 & 29.71 & 419.319141 \\
\hline 32 & 170.77 & 29.43 & 418.498079 \\
\hline 33 & 171.46 & 29.15 & 416.592574 \\
\hline 34 & 172.3 & 28.89 & 414.239624 \\
\hline 35 & 173 & 28.65 & 412.249785 \\
\hline 38 & 173.32 & 28.53 & 411.331029 \\
\hline 40 & 173.93 & 28.31 & 409.563288 \\
\hline 42 & 174.68 & 28.08 & 407.359397 \\
\hline 44 & 175.4 & 27.86 & 405.210683 \\
\hline 46 & 176.07 & 27.65 & 403.180809 \\
\hline 48 & 176.38 & 27.55 & 402.231329 \\
\hline 50 & 177.02 & 27.36 & 400.249766 \\
\hline 51 & 177.63 & 27.18 & 398.333333 \\
\hline 52 & 178.28 & 27 & 396.260048 \\
\hline 53 & 178.9 & 26.82 & 394.251061 \\
\hline 54 & 179.47 & 26.66 & 392.375766 \\
\hline
\end{tabular}


Zarka Ma'in $800 \mathrm{~m}$ away from the shoreline

\begin{tabular}{|c|c|c|c|c|c|c|c|}
\hline $\begin{array}{c}\text { Depth } \\
\text { [m] }\end{array}$ & $\begin{array}{c}\text { E.C. } \\
{[\mathrm{mS} / \mathrm{cm}]}\end{array}$ & $\begin{array}{c}\mathrm{T} . \\
{\left[\mathrm{C}^{\circ}\right]}\end{array}$ & $\begin{array}{l}\text { TDS } \\
{[\mathrm{g} / / \mathrm{l}}\end{array}$ & $\begin{array}{l}\text { Depth } \\
{[\mathrm{m}]}\end{array}$ & $\begin{array}{c}\text { E.C. } \\
{[\mathrm{mS} / \mathrm{cm}]}\end{array}$ & $\begin{array}{c}\mathrm{T} . \\
{\left[\mathrm{C}^{\circ}\right]}\end{array}$ & $\begin{array}{l}\text { TDS } \\
{[\mathrm{g} / \mathrm{l}]}\end{array}$ \\
\hline 1 & 197.44 & 31.91 & 295.437794 & & & & \\
\hline 2 & 196.57 & 32.17 & 306.071968 & 47 & 189.97 & 23.87 & 350.647485 \\
\hline 3 & 195.76 & 32.41 & 313.866008 & 48 & 190.09 & 23.84 & 350.049985 \\
\hline 4 & 194.19 & 32.7 & 326.131876 & 49 & 190.16 & 23.82 & 349.699458 \\
\hline 5 & 193.27 & 32.96 & 332.262229 & 50 & 190.28 & 23.8 & 349.095087 \\
\hline 6 & 191.48 & 33.16 & 342.787915 & 51 & 190.35 & 23.78 & 348.740482 \\
\hline 7 & 190.92 & 33.31 & 345.79385 & 52 & 190.43 & 23.76 & 348.333333 \\
\hline 8 & 190.13 & 33.41 & 349.849865 & 53 & 190.5 & 23.75 & 347.975406 \\
\hline 9 & 189.61 & 33.47 & 352.415006 & 54 & 190.61 & 23.72 & 347.409743 \\
\hline 10 & 189.34 & 33.53 & 353.717099 & 55 & 190.63 & 23.71 & 347.306469 \\
\hline 11 & 189.21 & 33.56 & 354.337136 & 56 & 190.7 & 23.7 & 346.943964 \\
\hline 12 & 188.07 & 33.59 & 359.597346 & 57 & 190.73 & 23.69 & 346.788102 \\
\hline 13 & 186.91 & 33.55 & 364.660431 & 58 & 190.82 & 23.67 & 346.318688 \\
\hline 14 & 186.84 & 33.52 & 364.957618 & 59 & 190.85 & 23.66 & 346.1616 \\
\hline 15 & 186.57 & 33.45 & 366.095592 & 60 & 190.88 & 23.66 & 346.004202 \\
\hline 16 & 186.37 & 33.3 & 366.930208 & 61 & 190.94 & 23.65 & 345.688464 \\
\hline 17 & 185.72 & 33.24 & 369.595984 & 62 & 190.96 & 23.63 & 345.582937 \\
\hline 18 & 184.18 & 33.13 & 375.651885 & 63 & 190.99 & 23.62 & 345.424382 \\
\hline 19 & 178.81 & 33.01 & 394.544647 & 64 & 190.99 & 23.62 & 345.424382 \\
\hline 20 & 178.29 & 32.7 & 396.227892 & 65 & 191.03 & 23.61 & 345.212478 \\
\hline 21 & 179.21 & 32.38 & 393.234611 & 66 & 191.07 & 23.6 & 345 \\
\hline 22 & 172.62 & 32.01 & 413.333333 & 67 & 191.13 & 23.59 & 344.680198 \\
\hline 23 & 166.12 & 31.57 & 430.763522 & 68 & 191.14 & 23.59 & 344.62677 \\
\hline 24 & 168.09 & 30.74 & 425.682739 & 69 & 191.16 & 23.58 & 344.519805 \\
\hline 25 & 169.41 & 30.03 & 422.185512 & 70 & 191.18 & 23.57 & 344.412692 \\
\hline 26 & 171.21 & 29.35 & 417.285759 & 71 & 191.22 & 23.56 & 344.198022 \\
\hline 27 & 173.48 & 28.62 & 410.869456 & 72 & 191.21 & 23.56 & 344.251745 \\
\hline 28 & 174.94 & 28.07 & 406.587279 & 73 & 191.3 & 23.55 & 343.76689 \\
\hline 29 & 176.89 & 27.49 & 400.654643 & 74 & 191.3 & 23.55 & 343.76689 \\
\hline 30 & 177.4 & 27.08 & 399.059181 & 75 & 191.32 & 23.54 & 343.65873 \\
\hline 31 & 179.35 & 26.63 & 392.772883 & 76 & 191.29 & 23.54 & 343.820913 \\
\hline 32 & 180.82 & 26.3 & 387.818546 & 77 & 191.35 & 23.53 & 343.496204 \\
\hline 33 & 182.11 & 25.95 & 383.297614 & 78 & 191.35 & 23.53 & 343.496204 \\
\hline 34 & 183 & 25.7 & 380.073506 & 79 & 191.42 & 23.51 & 343.115633 \\
\hline 35 & 183.98 & 25.43 & 376.413851 & 80 & 191.42 & 23.51 & 343.115633 \\
\hline 36 & 184.76 & 25.23 & 373.41143 & 81 & 191.43 & 23.51 & 343.061111 \\
\hline 37 & 185.49 & 25.02 & 370.522871 & 82 & 191.44 & 23.51 & 343.00655 \\
\hline 38 & 186.06 & 24.84 & 368.210308 & 83 & 191.46 & 23.5 & 342.897311 \\
\hline 39 & 186.77 & 24.65 & 365.253909 & 84 & 191.44 & 23.51 & 343.00655 \\
\hline 40 & 187.36 & 24.51 & 362.72799 & 85 & 191.46 & 23.5 & 342.897311 \\
\hline 41 & 188 & 24.37 & 359.910672 & 86 & 191.5 & 23.5 & 342.678362 \\
\hline 42 & 188.48 & 24.24 & 357.740507 & & & & \\
\hline 43 & 188.95 & 24.12 & 355.564236 & & & & \\
\hline 44 & 189.35 & 24.02 & 353.669221 & & & & \\
\hline 45 & 189.72 & 23.93 & 351.87882 & & & & \\
\hline 46 & 189.86 & 23.91 & 351.191482 & & & & \\
\hline
\end{tabular}


Sweimah $200 \mathrm{~m}$ away from the shoreline

\begin{tabular}{|c|c|c|c|c|c|c|c|}
\hline $\begin{array}{l}\text { Depth } \\
{[\mathrm{m}]}\end{array}$ & $\begin{array}{c}\text { E.C. } \\
{[\mathrm{mS} / \mathrm{cm}]}\end{array}$ & $\begin{array}{c}\mathrm{T} . \\
{[\mathrm{C}]}\end{array}$ & $\begin{array}{l}\text { TDS } \\
{[\mathrm{g} / \mathrm{ll}]}\end{array}$ & $\begin{array}{c}\text { Depth } \\
{[\mathrm{m}]}\end{array}$ & $\begin{array}{c}\text { E.C. } \\
{[\mathrm{mS} / \mathrm{cm}]}\end{array}$ & $\begin{array}{c}\mathrm{T} . \\
{[\mathrm{C}]}\end{array}$ & $\begin{array}{l}\text { TDS } \\
\text { [g/l] }\end{array}$ \\
\hline 1 & 190.35 & 33.52 & 348.74 & 48 & 171.63 & 25.94 & 416.119 \\
\hline 2 & 187.92 & 33.54 & 360.267 & 49 & 171.84 & 25.88 & 415.533 \\
\hline 3 & 186.09 & 33.58 & 368.087 & 50 & 171.95 & 25.84 & 415.225 \\
\hline 4 & 184.91 & 33.6 & 372.824 & 51 & 172.09 & 25.79 & 414.831 \\
\hline 5 & 184.17 & 33.59 & 375.69 & 52 & 172.29 & 25.74 & 414.268 \\
\hline 6 & 181.38 & 33.56 & 385.877 & 53 & 172.48 & 25.68 & 413.731 \\
\hline 7 & 177.34 & 33.51 & 399.248 & 54 & 172.61 & 25.64 & 413.362 \\
\hline 8 & 169.83 & 33.29 & 421.056 & 55 & 172.75 & 25.59 & 412.964 \\
\hline 9 & 166.49 & 33 & 429.821 & & & & \\
\hline 10 & 166.11 & 32.58 & 430.789 & & & & \\
\hline 11 & 167.74 & 32.07 & 426.597 & & & & \\
\hline 12 & 168.62 & 31.79 & 424.288 & & & & \\
\hline 13 & 169.44 & 31.51 & 422.105 & & & & \\
\hline 14 & 170.24 & 31.25 & 419.946 & & & & \\
\hline 15 & 170.95 & 31.01 & 418.003 & & & & \\
\hline 16 & 171.73 & 30.77 & 415.84 & & & & \\
\hline 17 & 172.44 & 30.56 & 413.844 & & & & \\
\hline 18 & 171.54 & 30.44 & 416.37 & & & & \\
\hline 19 & 171.08 & 29.79 & 417.645 & & & & \\
\hline 20 & 171.61 & 29.56 & 416.175 & & & & \\
\hline 21 & 172 & 29.34 & 415.084 & & & & \\
\hline 22 & 171.96 & 29.22 & 415.196 & & & & \\
\hline 23 & 172.63 & 29 & 413.305 & & & & \\
\hline 24 & 173.34 & 28.7 & 411.273 & & & & \\
\hline 25 & 172.69 & 28.58 & 413.134 & & & & \\
\hline 26 & 168.89 & 28.38 & 423.573 & & & & \\
\hline 27 & 164.78 & 28.18 & 434.131 & & & & \\
\hline 28 & 164.38 & 28.21 & 435.124 & & & & \\
\hline 29 & 164.94 & 27.9 & 433.733 & & & & \\
\hline 30 & 165.5 & 27.73 & 432.33 & & & & \\
\hline 31 & 166.07 & 27.56 & 430.89 & & & & \\
\hline 32 & 166.62 & 27.42 & 429.489 & & & & \\
\hline 33 & 166.94 & 27.33 & 428.668 & & & & \\
\hline 34 & 167.32 & 27.2 & 427.688 & & & & \\
\hline 35 & 167.77 & 27.07 & 426.519 & & & & \\
\hline 36 & 168.19 & 26.94 & 425.42 & & & & \\
\hline 37 & 168.61 & 26.84 & 424.314 & & & & \\
\hline 38 & 169.03 & 26.73 & 423.2 & & & & \\
\hline 39 & 169.21 & 26.67 & 422.72 & & & & \\
\hline 40 & 169.59 & 26.56 & 421.703 & & & & \\
\hline 41 & 169.91 & 26.46 & 420.84 & & & & \\
\hline 42 & 170.19 & 26.38 & 420.082 & & & & \\
\hline 43 & 170.48 & 26.29 & 419.292 & & & & \\
\hline 44 & 170.76 & 26.2 & 418.526 & & & & \\
\hline 45 & 170.92 & 26.16 & 418.086 & & & & \\
\hline 46 & 171.18 & 26.08 & 417.369 & & & & \\
\hline 47 & 171.47 & 26 & 416.565 & & & & \\
\hline
\end{tabular}


Sweimah 300 away from the shoreline

\begin{tabular}{|c|c|c|c|}
\hline $\begin{array}{c}\text { Depth } \\
\text { (m) }\end{array}$ & $\begin{array}{l}\text { E.C. } \\
{[\mathrm{mS}]}\end{array}$ & $\begin{array}{c}\mathrm{T} . \\
{[\mathrm{C}]}\end{array}$ & $\begin{array}{l}\text { TDS } \\
{[\mathrm{g} / \mathrm{l}]}\end{array}$ \\
\hline 1 & 198.4 & 30.1 & 271.937 \\
\hline 2 & 197.71 & 30.18 & 291.218 \\
\hline 3 & 196.76 & 30.23 & 304.009 \\
\hline 4 & 194.91 & 30.3 & 320.853 \\
\hline 5 & 190.43 & 30.36 & 348.333 \\
\hline 6 & 184.45 & 30.41 & 374.615 \\
\hline 7 & 179.84 & 30.51 & 391.143 \\
\hline 8 & 178.3 & 30.7 & 396.196 \\
\hline 9 & 178.02 & 30.33 & 397.093 \\
\hline 10 & 178.12 & 30.23 & 396.773 \\
\hline 11 & 175.95 & 30.05 & 403.547 \\
\hline 12 & 172.75 & 29.92 & 412.964 \\
\hline 13 & 171.75 & 29.75 & 415.784 \\
\hline 14 & 172.09 & 29.56 & 414.831 \\
\hline 15 & 171.97 & 29.44 & 415.168 \\
\hline 16 & 172.23 & 29.13 & 414.437 \\
\hline 17 & 172.64 & 28.9 & 413.277 \\
\hline 18 & 173.26 & 28.68 & 411.504 \\
\hline 19 & 173.9 & 28.44 & 409.651 \\
\hline 20 & 174.54 & 28.23 & 407.773 \\
\hline 21 & 175.32 & 28.01 & 405.451 \\
\hline 22 & 175.76 & 27.9 & 404.124 \\
\hline 23 & 176.65 & 27.62 & 401.399 \\
\hline 24 & 177.28 & 27.44 & 399.436 \\
\hline 25 & 177.77 & 27.26 & 397.89 \\
\hline 26 & 178.23 & 27.09 & 396.421 \\
\hline 27 & 178.51 & 27.01 & 395.518 \\
\hline 28 & 179.07 & 26.85 & 393.695 \\
\hline 29 & 179.64 & 26.69 & 391.811 \\
\hline 30 & 180.15 & 26.55 & 390.101 \\
\hline 31 & 180.56 & 26.43 & 388.709 \\
\hline 32 & 180.77 & 26.36 & 387.99 \\
\hline 33 & 181.17 & 26.24 & 386.609 \\
\hline 34 & 181.55 & 26.12 & 385.281 \\
\hline 35 & 181.96 & 26 & 383.832 \\
\hline 36 & 182.38 & 25.89 & 382.329 \\
\hline 37 & 182.74 & 25.79 & 381.025 \\
\hline 38 & 182.95 & 25.72 & 380.257 \\
\hline 39 & 183.33 & 25.62 & 378.855 \\
\hline 40 & 183.45 & 25.51 & 378.408 \\
\hline 41 & 184.74 & 25.41 & 373.489 \\
\hline 42 & 184.29 & 25.32 & 375.231 \\
\hline
\end{tabular}


Sweimah $400 \mathrm{~m}$ away from the shoreline

\begin{tabular}{|c|c|c|c|c|c|c|c|}
\hline $\begin{array}{c}\text { Depth } \\
\text { (m) }\end{array}$ & $\begin{array}{l}\text { E.C. } \\
{[\mathrm{mS}]}\end{array}$ & $\begin{array}{c}\mathrm{T} . \\
{[\mathrm{C}]}\end{array}$ & $\begin{array}{l}\text { TDS } \\
{[\mathrm{g} / \mathrm{l}]}\end{array}$ & $\begin{array}{l}\text { Depth } \\
(\mathrm{m})\end{array}$ & $\begin{array}{l}\text { E.C. } \\
\text { [mS] }\end{array}$ & $\begin{array}{c}\mathrm{T} . \\
{[\mathrm{C}]}\end{array}$ & $\begin{array}{l}\text { TDS } \\
{[\mathrm{g} / \mathrm{l}]}\end{array}$ \\
\hline 1 & 198.43 & 30.28 & 268.333 & 48 & 177.68 & 25.6 & 398.175 \\
\hline 2 & 198.4 & 30.54 & 271.937 & 49 & 177.81 & 25.51 & 397.762 \\
\hline 3 & 197.2 & 30.77 & 298.726 & 50 & 177.72 & 25.48 & 398.048 \\
\hline 4 & 194.83 & 31.07 & 321.464 & 51 & 178.28 & 25.39 & 396.26 \\
\hline 5 & 193.07 & 31.22 & 333.521 & 52 & 178.36 & 25.31 & 396.003 \\
\hline 6 & 189.55 & 31.33 & 352.706 & 53 & 178.9 & 25.24 & 394.251 \\
\hline 7 & 185.97 & 31.43 & 368.579 & 54 & 179.22 & 25.17 & 393.202 \\
\hline 8 & 184.15 & 31.47 & 375.767 & 55 & 179.44 & 25.11 & 392.475 \\
\hline 9 & 183.93 & 31.48 & 376.604 & 56 & 179.62 & 25.07 & 391.878 \\
\hline 10 & 182.03 & 31.47 & 383.583 & 57 & 179.83 & 25.01 & 391.177 \\
\hline 11 & 178.66 & 31.41 & 395.032 & 58 & 180.03 & 24.96 & 390.506 \\
\hline 12 & 175.66 & 31.35 & 404.427 & 59 & 180.23 & 24.9 & 389.831 \\
\hline 13 & 174.95 & 31.25 & 406.557 & 60 & 180.35 & 24.87 & 389.424 \\
\hline 14 & 174.76 & 31.12 & 407.122 & 61 & 180.53 & 24.81 & 388.812 \\
\hline 15 & 171.96 & 30.96 & 415.196 & 62 & 180.79 & 24.75 & 387.922 \\
\hline 16 & 170.48 & 30.79 & 419.292 & 63 & 180.99 & 24.7 & 387.232 \\
\hline 17 & 169.22 & 30.59 & 422.694 & 64 & 181.15 & 24.66 & 386.678 \\
\hline 18 & 169.5 & 30.37 & 421.944 & 65 & 181.31 & 24.62 & 386.121 \\
\hline 19 & 170.14 & 30.01 & 420.217 & 66 & 181.42 & 24.58 & 385.737 \\
\hline 20 & 170.51 & 29.89 & 419.21 & 67 & 181.57 & 24.54 & 385.211 \\
\hline 21 & 170.8 & 29.64 & 418.416 & 68 & 181.75 & 24.49 & 384.577 \\
\hline 22 & 171.22 & 29.4 & 417.258 & 70 & 181.88 & 24.44 & 384.116 \\
\hline 23 & 171.79 & 29.16 & 415.673 & 72 & 182.11 & 24.4 & 383.298 \\
\hline 24 & 172.39 & 28.93 & 413.985 & 74 & 182.27 & 24.35 & 382.725 \\
\hline 25 & 173.15 & 28.69 & 411.82 & 76 & 182.37 & 24.33 & 382.365 \\
\hline 26 & 173.85 & 28.46 & 409.796 & 78 & 182.47 & 24.29 & 382.004 \\
\hline 27 & 174.2 & 28.35 & 408.774 & 80 & 182.61 & 24.25 & 381.497 \\
\hline 28 & 174.84 & 28.13 & 406.885 & 82 & 182.73 & 24.22 & 381.061 \\
\hline 29 & 175.51 & 27.93 & 404.879 & 84 & 182.85 & 24.19 & 380.623 \\
\hline 30 & 176.12 & 27.74 & 403.028 & 86 & 182.93 & 24.17 & 380.33 \\
\hline 31 & 174.92 & 27.55 & 406.647 & 88 & 182.98 & 24.15 & 380.147 \\
\hline 32 & 176.11 & 27.36 & 403.059 & 90 & 183.13 & 24.12 & 379.595 \\
\hline 33 & 176.63 & 27.26 & 401.461 & 92 & 183.16 & 24.1 & 379.484 \\
\hline 34 & 177.29 & 27.09 & 399.405 & 94 & 183.23 & 24.07 & 379.225 \\
\hline 35 & 177.93 & 26.94 & 397.381 & & & & \\
\hline 36 & 178.33 & 26.8 & 396.099 & & & & \\
\hline 37 & 178.87 & 26.67 & 394.349 & & & & \\
\hline 38 & 176.64 & 26.54 & 401.43 & & & & \\
\hline 39 & 175 & 26.47 & 406.408 & & & & \\
\hline 40 & 175.23 & 26.35 & 405.721 & & & & \\
\hline 41 & 175.67 & 26.23 & 404.396 & & & & \\
\hline 42 & 176.05 & 26.12 & 403.242 & & & & \\
\hline 43 & 176.43 & 26.01 & 402.078 & & & & \\
\hline 44 & 176.63 & 25.95 & 401.461 & & & & \\
\hline 45 & 176.97 & 25.86 & 400.406 & & & & \\
\hline 46 & 177.27 & 25.77 & 399.468 & & & & \\
\hline 47 & 177.48 & 25.68 & 398.807 & & & & \\
\hline
\end{tabular}


Sweimah $500 \mathrm{~m}$ away from the shoreline

\begin{tabular}{|c|c|c|c|c|c|c|c|}
\hline $\begin{array}{c}\text { Depth } \\
(\mathrm{m})\end{array}$ & $\begin{array}{l}\text { E.C. } \\
\text { [mS] }\end{array}$ & $\begin{array}{c}\mathrm{T} . \\
{[\mathrm{C}]}\end{array}$ & $\begin{array}{l}\text { TDS } \\
{[\mathrm{g} / \mathrm{l}]}\end{array}$ & $\begin{array}{l}\text { Depth } \\
\text { (m) }\end{array}$ & $\begin{array}{l}\text { E.C. } \\
\text { [mS] }\end{array}$ & $\begin{array}{c}\mathrm{T} . \\
{[\mathrm{C}]}\end{array}$ & $\begin{array}{l}\text { TDS } \\
{[\mathrm{g} / \mathrm{ll}]}\end{array}$ \\
\hline 1 & 198.4 & 30.16 & 271.937 & 64 & 180.19 & 26.43 & 389.966 \\
\hline 2 & 198.39 & 30.29 & 272.676 & 66 & 180.73 & 26.28 & 388.128 \\
\hline 3 & 198.39 & 30.5 & 272.676 & 68 & 180.97 & 26.22 & 387.302 \\
\hline 4 & 198.38 & 30.68 & 273.333 & 70 & 181.72 & 26.02 & 384.683 \\
\hline 5 & 198.35 & 30.84 & 275 & 72 & 182.09 & 25.92 & 383.369 \\
\hline 6 & 198.3 & 30.99 & 277.208 & 74 & 182.65 & 25.77 & 381.352 \\
\hline 7 & 198.2 & 31.14 & 280.611 & 76 & 183.06 & 25.66 & 379.853 \\
\hline 8 & 198.1 & 31.22 & 283.333 & 78 & 183.26 & 25.61 & 379.114 \\
\hline 9 & 197.89 & 31.37 & 287.945 & 80 & 183.66 & 25.5 & 377.622 \\
\hline 10 & 196.1 & 31.42 & 310.763 & 82 & 184.09 & 25.4 & 375.995 \\
\hline 11 & 195.3 & 31.62 & 317.766 & 84 & 184.5 & 25.28 & 374.422 \\
\hline 12 & 194.78 & 31.72 & 321.843 & 86 & 184.86 & 25.19 & 373.02 \\
\hline 13 & 193.16 & 31.79 & 332.957 & 88 & 185.18 & 25.11 & 371.759 \\
\hline 14 & 191.97 & 31.84 & 340.057 & & & & \\
\hline 15 & 190.88 & 31.91 & 346.004 & & & & \\
\hline 16 & 190.65 & 31.95 & 347.203 & & & & \\
\hline 17 & 189.79 & 31.98 & 351.536 & & & & \\
\hline 18 & 186.3 & 32 & 367.221 & & & & \\
\hline 19 & 179.86 & 32.01 & 391.076 & & & & \\
\hline 20 & 176.51 & 32.01 & 401.831 & & & & \\
\hline 21 & 176.36 & 31.92 & 402.293 & & & & \\
\hline 22 & 176.68 & 31.78 & 401.306 & & & & \\
\hline 23 & 173.6 & 31.64 & 410.522 & & & & \\
\hline 24 & 168.83 & 31.48 & 423.732 & & & & \\
\hline 25 & 166.86 & 31.38 & 428.874 & & & & \\
\hline 26 & 167.29 & 31.15 & 427.765 & & & & \\
\hline 27 & 168.15 & 30.87 & 425.525 & & & & \\
\hline 28 & 169 & 30.57 & 423.28 & & & & \\
\hline 29 & 169.12 & 30.31 & 422.961 & & & & \\
\hline 30 & 168.88 & 30.15 & 423.599 & & & & \\
\hline 32 & 169.54 & 29.86 & 421.837 & & & & \\
\hline 34 & 170.49 & 29.55 & 419.265 & & & & \\
\hline 36 & 171.23 & 29.26 & 417.23 & & & & \\
\hline 38 & 171.93 & 28.99 & 415.281 & & & & \\
\hline 40 & 172.73 & 28.73 & 413.02 & & & & \\
\hline 42 & 173.11 & 28.61 & 411.935 & & & & \\
\hline 44 & 173.84 & 28.37 & 409.825 & & & & \\
\hline 46 & 174.6 & 28.13 & 407.596 & & & & \\
\hline 48 & 175.41 & 27.88 & 405.181 & & & & \\
\hline 50 & 176.09 & 27.67 & 403.12 & & & & \\
\hline 52 & 176.85 & 27.45 & 400.779 & & & & \\
\hline 54 & 177.49 & 27.25 & 398.776 & & & & \\
\hline 56 & 177.83 & 27.15 & 397.699 & & & & \\
\hline 58 & 178.54 & 26.92 & 395.421 & & & & \\
\hline 60 & 179.05 & 26.77 & 393.76 & & & & \\
\hline 62 & 179.69 & 26.58 & 391.644 & & & & \\
\hline
\end{tabular}


Sweimah $800 \mathrm{~m}$ away from the shoreline.

\begin{tabular}{|c|c|c|c|c|c|c|c|}
\hline $\begin{array}{c}\text { Depth } \\
\text { (m) }\end{array}$ & $\begin{array}{l}\text { E.C. } \\
\text { [mS] }\end{array}$ & $\begin{array}{c}\mathrm{T} . \\
{[\mathrm{C}]}\end{array}$ & $\begin{array}{l}\text { TDS } \\
{[\mathrm{g} / \mathrm{l}]}\end{array}$ & $\begin{array}{c}\text { Depth } \\
(\mathrm{m})\end{array}$ & $\begin{array}{l}\text { E.C. } \\
\text { [mS] }\end{array}$ & $\begin{array}{c}\mathrm{T} . \\
{[\mathrm{C}]}\end{array}$ & $\begin{array}{l}\text { TDS } \\
{[\mathrm{g} / \mathrm{l}]}\end{array}$ \\
\hline 1 & 198 & 30.71 & 285.67 & 47 & 185.41 & 25.05 & 370.843 \\
\hline 2 & 197.33 & 31 & 296.989 & 48 & 185.66 & 24.98 & 369.839 \\
\hline 3 & 193.7 & 31.37 & 329.471 & 49 & 185.79 & 24.92 & 369.312 \\
\hline 4 & 188.03 & 31.61 & 359.777 & 50 & 186.05 & 24.85 & 368.251 \\
\hline 5 & 177.5 & 31.71 & 398.744 & 51 & 186.28 & 24.79 & 367.304 \\
\hline 6 & 176.89 & 31.6 & 400.655 & 52 & 186.48 & 24.73 & 366.472 \\
\hline 7 & 177.85 & 31.36 & 397.635 & 53 & 186.67 & 24.67 & 365.676 \\
\hline 8 & 178.71 & 31.09 & 394.87 & 54 & 186.8 & 24.64 & 365.127 \\
\hline 9 & 179.29 & 30.86 & 392.971 & 55 & 187.02 & 24.58 & 364.192 \\
\hline 10 & 180.5 & 30.65 & 388.914 & 56 & 187.22 & 24.53 & 363.333 \\
\hline 11 & 180.65 & 30.45 & 388.402 & 57 & 187.41 & 24.47 & 362.511 \\
\hline 12 & 181.2 & 30.28 & 386.505 & 58 & 187.59 & 24.44 & 361.725 \\
\hline 13 & 181.85 & 30.11 & 384.223 & 59 & 187.83 & 24.38 & 360.667 \\
\hline 14 & 179.92 & 29.98 & 390.875 & 60 & 187.98 & 24.34 & 360 \\
\hline 15 & 173.06 & 29.82 & 412.078 & 61 & 188.17 & 24.3 & 359.148 \\
\hline 16 & 172.35 & 29.56 & 414.098 & 62 & 188.32 & 24.26 & 358.47 \\
\hline 17 & 173.67 & 29.1 & 410.319 & 63 & 188.55 & 24.21 & 357.42 \\
\hline 18 & 173.84 & 28.81 & 409.825 & 64 & 188.64 & 24.19 & 357.006 \\
\hline 19 & 174.36 & 28.43 & 408.304 & 65 & 188.78 & 24.15 & 356.357 \\
\hline 20 & 175.21 & 28.14 & 405.781 & 66 & 188.96 & 24.12 & 355.517 \\
\hline 21 & 176.38 & 27.79 & 402.231 & 67 & 189.15 & 24.07 & 354.622 \\
\hline 22 & 177.52 & 27.46 & 398.681 & 68 & 189.31 & 24.03 & 353.861 \\
\hline 23 & 178.28 & 27.24 & 396.26 & 69 & 189.44 & 24 & 353.237 \\
\hline 24 & 178.93 & 27.04 & 394.153 & 70 & 189.54 & 23.98 & 352.754 \\
\hline 25 & 179.13 & 26.98 & 393.498 & 71 & 189.7 & 23.95 & 351.977 \\
\hline 26 & 179.44 & 26.85 & 392.475 & 72 & 189.86 & 23.9 & 351.191 \\
\hline 27 & 179.71 & 26.73 & 391.578 & 73 & 190.02 & 23.87 & 350.399 \\
\hline 28 & 180.04 & 26.61 & 390.472 & 74 & 190.11 & 23.85 & 349.95 \\
\hline 29 & 180.47 & 26.48 & 389.016 & 75 & 190.29 & 23.82 & 349.045 \\
\hline 30 & 180.84 & 26.37 & 387.75 & 76 & 190.35 & 23.79 & 348.74 \\
\hline 31 & 180.96 & 26.31 & 387.336 & 77 & 190.43 & 23.79 & 348.333 \\
\hline 32 & 181.3 & 26.2 & 386.156 & 78 & 190.55 & 23.76 & 347.719 \\
\hline 33 & 181.69 & 26.1 & 384.789 & 79 & 190.68 & 23.72 & 347.048 \\
\hline 34 & 182.11 & 25.99 & 383.298 & 80 & 190.83 & 23.7 & 346.266 \\
\hline 35 & 182.51 & 25.88 & 381.86 & 81 & 190.87 & 23.69 & 346.057 \\
\hline 36 & 182.84 & 25.79 & 380.66 & 82 & 190.94 & 23.67 & 345.688 \\
\hline 37 & 183.05 & 25.74 & 379.89 & 83 & 190.99 & 23.65 & 345.424 \\
\hline 38 & 183.36 & 25.65 & 378.743 & 84 & 191.06 & 23.63 & 345.053 \\
\hline 39 & 183.65 & 25.57 & 377.66 & 85 & 191.11 & 23.62 & 344.787 \\
\hline 40 & 183.82 & 25.49 & 377.02 & 86 & 191.21 & 23.6 & 344.252 \\
\hline 41 & 183.95 & 25.45 & 376.528 & 87 & 191.24 & 23.6 & 344.09 \\
\hline 42 & 184.2 & 25.37 & 375.575 & 88 & 191.33 & 23.57 & 343.605 \\
\hline 43 & 184.49 & 25.29 & 374.46 & 89 & 191.37 & 23.56 & 343.388 \\
\hline 44 & 184.83 & 25.21 & 373.138 & 90 & 191.38 & 23.55 & 343.333 \\
\hline 45 & 185.1 & 25.14 & 372.076 & 91 & 191.49 & 23.54 & 342.733 \\
\hline 46 & 185.31 & 25.08 & 371.243 & 92 & 191.51 & 23.53 & 342.624 \\
\hline & & & & 93 & 191.55 & 23.52 & 342.404 \\
\hline
\end{tabular}


Zara $100 \mathrm{~m}$ away from the shoreline

\begin{tabular}{|c|c|c|c|c|c|c|c|}
\hline $\begin{array}{c}\text { Depth } \\
{[\mathrm{m}]}\end{array}$ & $\begin{array}{c}\text { E.C. } \\
{[\mathrm{mS} / \mathrm{cm}]}\end{array}$ & $\begin{array}{c}\mathrm{T} . \\
{\left[\mathrm{C}^{\circ}\right]}\end{array}$ & $\begin{array}{l}\text { TDS } \\
\text { [g/l] }\end{array}$ & $\begin{array}{l}\text { Depth } \\
{[\mathrm{m}]}\end{array}$ & $\begin{array}{c}\text { E.C. } \\
{[\mathrm{mS} / \mathrm{cm}]}\end{array}$ & $\begin{array}{c}\mathrm{T} . \\
{\left[\mathrm{C}^{\circ}\right]}\end{array}$ & $\begin{array}{l}\text { TDS } \\
{[\mathrm{g} / \mathrm{ll}]}\end{array}$ \\
\hline 1 & 159.9 & 43.44 & 445.8624007 & 47 & 176.85 & 27.46 & 400.7789745 \\
\hline 2 & 162.01 & 42.61 & 440.8871528 & 48 & 177.53 & 27.37 & 398.6494096 \\
\hline 3 & 164.26 & 41.76 & 435.4202675 & 49 & 178.22 & 27.2 & 396.4528156 \\
\hline 4 & 165.99 & 40.98 & 431.0932798 & 50 & 178.78 & 27.04 & 394.6423588 \\
\hline 5 & 167.34 & 40.27 & 427.6359529 & 51 & 179.2 & 26.89 & 393.2675268 \\
\hline 6 & 168.16 & 39.93 & 425.499213 & 52 & 179.7 & 26.74 & 391.6110988 \\
\hline 7 & 168.9 & 39.59 & 423.545955 & 53 & 180.15 & 26.6 & 390.1013097 \\
\hline 8 & 169.34 & 39.43 & 422.3729429 & 54 & 180.41 & 26.54 & 389.2205097 \\
\hline 9 & 170.22 & 39.13 & 420 & 55 & 180.87 & 26.4 & 387.646463 \\
\hline 10 & 170.88 & 38.82 & 418.1959084 & 56 & 181.35 & 26.27 & 385.9818422 \\
\hline 11 & 169.44 & 38.53 & 422.1051146 & 57 & 181.47 & 26.15 & 385.5620455 \\
\hline 12 & 164.69 & 38.26 & 434.3552007 & 58 & 182.06 & 26.02 & 383.4761031 \\
\hline 13 & 160.56 & 37.98 & 444.3211378 & 59 & 181.91 & 25.9 & 384.0099428 \\
\hline 14 & 153.32 & 37.82 & 460.5595351 & 60 & 180.79 & 25.85 & 387.921678 \\
\hline 15 & 151.66 & 37.47 & 464.0945719 & 61 & 181.07 & 25.75 & 386.9556705 \\
\hline 16 & 152.33 & 37.06 & 462.6754533 & 62 & 181.47 & 25.65 & 385.5620455 \\
\hline 17 & 153.13 & 36.58 & 460.9674072 & 63 & 180.87 & 25.57 & 387.646463 \\
\hline 18 & 154.03 & 36.08 & 459.0277276 & 64 & 180.93 & 25.48 & 387.4396401 \\
\hline 19 & 155.16 & 35.57 & 456.5642999 & 65 & 181.49 & 25.41 & 385.4919352 \\
\hline 20 & 155.55 & 35.31 & 455.7066389 & 66 & 181.7 & 25.37 & 384.7532639 \\
\hline 21 & 156.64 & 34.81 & 453.2886851 & 67 & 182 & 25.3 & 383.6899312 \\
\hline 22 & 157.59 & 34.33 & 451.1554498 & 68 & 182.25 & 25.23 & 382.7963834 \\
\hline 23 & 158.41 & 33.87 & 449.2940955 & 69 & 182.43 & 25.17 & 382.148748 \\
\hline 24 & 159.54 & 33.42 & 446.6975282 & 70 & 182.77 & 25.07 & 380.9154206 \\
\hline 25 & 160.76 & 32.98 & 443.8514415 & 71 & 182.98 & 25.02 & 380.1469635 \\
\hline 26 & 161.35 & 32.77 & 442.4585259 & 72 & 183.27 & 24.96 & 379.0771249 \\
\hline 27 & 162.56 & 32.36 & 439.5667663 & 73 & 183.46 & 24.91 & 378.3706405 \\
\hline 28 & 163.67 & 31.98 & 436.8707925 & 74 & 183.69 & 24.86 & 377.5093981 \\
\hline 29 & 164.77 & 31.61 & 434.1563015 & 75 & 183.84 & 24.82 & 376.9440946 \\
\hline 30 & 165.82 & 31.26 & 431.5235069 & 76 & 184 & 24.7 & 376.3378925 \\
\hline 31 & 166.24 & 31.09 & 430.45854 & 77 & 184.51 & 24.66 & 374.3828575 \\
\hline 32 & 167.19 & 30.77 & 428.0237586 & 78 & 186.32 & 24.61 & 367.1377792 \\
\hline 33 & 168.16 & 30.46 & 425.499213 & 79 & 186.14 & 24.58 & 367.8815097 \\
\hline 34 & 169.04 & 30.16 & 423.1736775 & 80 & 186.13 & 24.56 & 367.9226679 \\
\hline 35 & 169.94 & 29.89 & 420.7589911 & 82 & 186.33 & 24.51 & 367.0962993 \\
\hline 36 & 170.7 & 29.63 & 418.6900567 & 84 & 186.18 & 24.47 & 367.7167093 \\
\hline 37 & 170.92 & 29.5 & 418.0858787 & & & & \\
\hline 38 & 171.64 & 29.26 & 416.0914898 & & & & \\
\hline 39 & 172.33 & 29.01 & 414.154896 & & & & \\
\hline 40 & 173 & 28.79 & 412.2497853 & & & & \\
\hline 41 & 173.76 & 28.55 & 410.0581277 & & & & \\
\hline 42 & 174.49 & 28.33 & 407.9209685 & & & & \\
\hline 43 & 174.72 & 28.23 & 407.2408859 & & & & \\
\hline 44 & 175.99 & 28.02 & 403.4247662 & & & & \\
\hline 45 & 176.5 & 27.82 & 401.8619986 & & & & \\
\hline 46 & 176.5 & 27.64 & 401.8619986 & & & & \\
\hline
\end{tabular}


Zara $300 \mathrm{~m}$ away from the shoreline

\begin{tabular}{|c|c|c|c|c|c|c|c|}
\hline $\begin{array}{c}\text { Depth } \\
{[\mathrm{m}]}\end{array}$ & $\begin{array}{c}\text { E.C. } \\
{[\mathrm{mS} / \mathrm{cm}]}\end{array}$ & $\begin{array}{c}\mathrm{T} . \\
{\left[\mathrm{C}^{\circ}\right]}\end{array}$ & $\begin{array}{l}\text { TDS } \\
{[\mathrm{g} / \mathrm{l}]}\end{array}$ & $\begin{array}{c}\text { Depth } \\
{[\mathrm{m}]}\end{array}$ & $\begin{array}{c}\text { E.C. } \\
{[\mathrm{mS} / \mathrm{cm}]}\end{array}$ & $\begin{array}{c}\text { T. } \\
{\left[\mathrm{C}^{\circ}\right]}\end{array}$ & $\begin{array}{l}\text { TDS } \\
{[\mathrm{g} / \mathrm{l}]}\end{array}$ \\
\hline 1 & 189.44 & 33.3 & 353.2371261 & 47 & 180.47 & 26.71 & 389.0163477 \\
\hline 2 & 189.09 & 33.36 & 354.9056099 & 48 & 180.84 & 26.59 & 387.7497419 \\
\hline 3 & 189.22 & 33.4 & 354.2895962 & 49 & 181.02 & 26.54 & 387.12874 \\
\hline 4 & 189.11 & 33.43 & 354.8111188 & 50 & 181.29 & 26.42 & 386.1911876 \\
\hline 5 & 188.92 & 33.46 & 355.7047359 & 51 & 181.47 & 26.32 & 385.5620455 \\
\hline 6 & 188.45 & 33.47 & 357.8776553 & 52 & 181.69 & 26.22 & 384.7885435 \\
\hline 7 & 187.41 & 33.47 & 362.5108689 & 53 & 182.36 & 26.13 & 382.4010369 \\
\hline 8 & 187.36 & 33.45 & 362.7279897 & 54 & 182.18 & 26.03 & 383.0472683 \\
\hline 9 & 187.11 & 33.36 & 363.8063141 & 55 & 182.3 & 25.98 & 382.6168475 \\
\hline 10 & 185.05 & 33.34 & 372.2733794 & 56 & 183.06 & 25.89 & 379.8528456 \\
\hline 11 & 180.79 & 33.32 & 387.921678 & 57 & 183.31 & 25.81 & 378.9287608 \\
\hline 12 & 174.49 & 33.11 & 407.9209685 & 58 & 183.37 & 25.73 & 378.7058463 \\
\hline 13 & 173.63 & 32.97 & 410.4353853 & 59 & 183.76 & 25.64 & 377.2459494 \\
\hline 14 & 173.38 & 32.71 & 411.158112 & 60 & 183.86 & 25.57 & 376.8685017 \\
\hline 15 & 174 & 32.63 & 409.359032 & 61 & 184.01 & 25.52 & 376.2998936 \\
\hline 16 & 174.8 & 32.34 & 407.0035629 & 62 & 184.4 & 25.45 & 374.8075213 \\
\hline 17 & 175.19 & 32.14 & 405.8408182 & 63 & 184.68 & 25.37 & 373.7232457 \\
\hline 18 & 175.83 & 31.97 & 403.9113792 & 64 & 185.13 & 25.25 & 371.9572698 \\
\hline 19 & 176.56 & 31.45 & 401.6769543 & 65 & 185.42 & 25.18 & 370.803329 \\
\hline 20 & 174.53 & 31.2 & 407.8029286 & 66 & 185.55 & 25.14 & 370.2818736 \\
\hline 21 & 173.14 & 31.21 & 411.8485449 & 67 & 185.76 & 25.08 & 369.4339334 \\
\hline 22 & 172.84 & 31.04 & 412.706996 & 68 & 185.95 & 25.02 & 368.6606752 \\
\hline 23 & 172.61 & 30.85 & 413.3617397 & 69 & 186.33 & 24.91 & 367.0962993 \\
\hline 24 & 172.81 & 30.66 & 412.7925637 & 70 & 186.45 & 24.88 & 366.5971981 \\
\hline 25 & 171.03 & 30.36 & 417.7828839 & 71 & 186.69 & 24.82 & 365.5914417 \\
\hline 26 & 171.55 & 30.15 & 416.3422418 & 72 & 186.9 & 24.77 & 364.7029411 \\
\hline 27 & 172.23 & 29.93 & 414.4371343 & 73 & 187.05 & 24.71 & 364.0633356 \\
\hline 28 & 172.92 & 29.72 & 412.4785699 & 74 & 187.22 & 24.66 & 363.3333333 \\
\hline 29 & 173.42 & 29.5 & 411.0427189 & 75 & 187.38 & 24.62 & 362.6412003 \\
\hline 30 & 173.63 & 29.3 & 410.4353853 & 76 & 187.49 & 24.6 & 362.162449 \\
\hline 31 & 173.11 & 29.21 & 411.9346183 & 77 & 187.66 & 24.55 & 361.4178027 \\
\hline 32 & 173.13 & 29.01 & 411.8772417 & 78 & 187.75 & 24.51 & 361.021199 \\
\hline 33 & 173.47 & 28.81 & 410.8983476 & 79 & 187.89 & 24.46 & 360.4009246 \\
\hline 34 & 174.34 & 28.62 & 408.362742 & 80 & 188.09 & 24.42 & 359.5076298 \\
\hline 35 & 174.9 & 28.43 & 406.7063436 & 81 & 188.24 & 24.38 & 358.8319771 \\
\hline 36 & 175.32 & 28.24 & 405.4510718 & 82 & 188.28 & 24.36 & 358.6509648 \\
\hline 37 & 175.58 & 28.15 & 404.668277 & 83 & 188.43 & 24.32 & 357.9689728 \\
\hline 38 & 176.16 & 27.98 & 402.9058355 & 84 & 188.6 & 24.29 & 357.1898374 \\
\hline 39 & 176.79 & 27.79 & 400.9652561 & 85 & 188.69 & 24.25 & 356.7746266 \\
\hline 40 & 177.28 & 27.63 & 399.4363084 & 86 & 188.82 & 24.22 & 356.1714772 \\
\hline 41 & 177.77 & 27.47 & 397.8895475 & 87 & 188.96 & 24.19 & 355.5173529 \\
\hline 42 & 178.34 & 27.32 & 396.066993 & 88 & 189.17 & 24.16 & 354.5270357 \\
\hline 43 & 178.89 & 27.17 & 394.2837153 & 89 & 189.31 & 24.12 & 353.8605757 \\
\hline 44 & 179.15 & 27.1 & 393.4319791 & & & & \\
\hline 45 & 179.64 & 26.96 & 391.8110278 & & & & \\
\hline 46 & 180.06 & 26.83 & 390.4047413 & & & & \\
\hline
\end{tabular}


Zara $400 \mathrm{~m}$ away from the shoreline

\begin{tabular}{|c|c|c|c|c|c|c|c|}
\hline $\begin{array}{c}\text { Depth } \\
\text { [m] }\end{array}$ & $\begin{array}{c}\text { E.C. } \\
{[\mathrm{mS} / \mathrm{cm}]}\end{array}$ & $\begin{array}{c}\mathrm{T} . \\
{\left[\mathrm{C}^{\circ}\right]}\end{array}$ & $\begin{array}{c}\text { TDS } \\
{[\mathrm{g} / \mathrm{l}]}\end{array}$ & $\begin{array}{c}\text { Depth } \\
\text { [m] }\end{array}$ & $\begin{array}{c}\text { E.C. } \\
{[\mathrm{mS} / \mathrm{cm}]}\end{array}$ & $\begin{array}{c}\mathrm{T} . \\
{\left[\mathrm{C}^{\circ}\right]}\end{array}$ & $\begin{array}{c}\mathrm{TDS} \\
{[\mathrm{g} / \mathrm{l}]}\end{array}$ \\
\hline 1 & 198.4 & 31.08 & 271.9371294 & 49 & 187.51 & 24.52 & 362.0751452 \\
\hline 2 & 197.04 & 31.4 & 300.7417472 & 50 & 187.86 & 24.41 & 360.5341856 \\
\hline 3 & 195.83 & 31.65 & 313.243962 & 51 & 188.24 & 24.31 & 358.8319771 \\
\hline 4 & 195.96 & 31.85 & 312.0661282 & 52 & 188.54 & 24.24 & 357.4655898 \\
\hline 5 & 196.15 & 31.93 & 310.2875078 & 53 & 188.82 & 24.16 & 356.1714772 \\
\hline 6 & 194.9 & 32.01 & 320.929402 & 54 & 189.04 & 24.12 & 355.1413963 \\
\hline 7 & 193.71 & 32.15 & 329.4051007 & 55 & 189.24 & 24.06 & 354.19444 \\
\hline 8 & 193.59 & 32.22 & 330.1970618 & 56 & 189.45 & 24.01 & 353.1889823 \\
\hline 9 & 192.18 & 32.25 & 338.8546928 & 57 & 189.63 & 23.96 & 352.3177677 \\
\hline 10 & 188.69 & 32.29 & 356.7746266 & 58 & 189.73 & 23.93 & 351.8299086 \\
\hline 11 & 185.65 & 32.34 & 369.8789614 & 59 & 189.88 & 23.9 & 351.0928343 \\
\hline 12 & 182.45 & 32.35 & 382.0765642 & 60 & 190.02 & 23.86 & 350.3990446 \\
\hline 13 & 178.15 & 32.33 & 396.67735 & 61 & 190.11 & 23.84 & 349.949985 \\
\hline 14 & 170.53 & 32.29 & 419.1552819 & 62 & 190.23 & 23.82 & 349.347445 \\
\hline 15 & 169.31 & 32.2 & 422.4532015 & 63 & 190.32 & 23.8 & 348.8926426 \\
\hline 16 & 167.82 & 32.04 & 426.3886473 & 64 & 190.63 & 23.78 & 347.3064694 \\
\hline 17 & 166.21 & 31.8 & 430.5348386 & 65 & 190.74 & 23.76 & 346.736081 \\
\hline 18 & 166.52 & 31.53 & 429.7446984 & 66 & 190.85 & 23.73 & 346.1616001 \\
\hline 19 & 166.86 & 31.25 & 428.8736675 & 67 & 190.93 & 23.71 & 345.7411744 \\
\hline 20 & 166.98 & 31.23 & 428.5651259 & 68 & 190.95 & 23.7 & 345.6357183 \\
\hline 21 & 167.58 & 30.78 & 427.0135129 & 69 & 191.03 & 23.68 & 345.2124778 \\
\hline 22 & 168.14 & 30.47 & 425.5516705 & 70 & 191.12 & 23.67 & 344.7335895 \\
\hline 23 & 168.92 & 30.16 & 423.4928266 & 71 & 191.22 & 23.65 & 344.1980223 \\
\hline 24 & 169.8 & 29.85 & 421.1370881 & 72 & 191.4 & 23.62 & 343.2245605 \\
\hline 25 & 170.61 & 29.55 & 418.9365294 & 73 & 191.48 & 23.59 & 342.787915 \\
\hline 26 & 170.98 & 29.4 & 417.9206841 & 74 & 191.64 & 23.56 & 341.9070223 \\
\hline 27 & 171.92 & 29.11 & 415.3086676 & 75 & 191.66 & 23.55 & 341.7961845 \\
\hline 28 & 172.81 & 28.84 & 412.7925637 & 76 & 191.72 & 23.54 & 341.4626856 \\
\hline 30 & 173.63 & 28.58 & 410.4353853 & 77 & 191.8 & 23.52 & 341.0156934 \\
\hline 31 & 174.44 & 28.34 & 408.0683797 & 78 & 191.83 & 23.51 & 340.8473769 \\
\hline 32 & 176.92 & 27.59 & 400.5613185 & 79 & 191.89 & 23.5 & 340.5095931 \\
\hline 33 & 177.52 & 27.42 & 398.6809757 & 80 & 191.93 & 23.49 & 340.2835428 \\
\hline 34 & 178.91 & 27.01 & 394.2183991 & 81 & 191.94 & 23.48 & 340.2269216 \\
\hline 35 & 179.89 & 26.72 & 390.975869 & 82 & 191.95 & 23.48 & 340.1702569 \\
\hline 36 & 180.8 & 26.47 & 387.8873103 & 83 & 191.96 & 23.47 & 340.1135485 \\
\hline 37 & 181.27 & 26.3 & 386.260888 & 84 & 192.06 & 23.45 & 339.544037 \\
\hline 38 & 181.98 & 26.08 & 383.7611205 & 85 & 192.03 & 23.46 & 339.7153567 \\
\hline 39 & 182.63 & 25.89 & 381.4248666 & 86 & 192.04 & 23.46 & 339.6582948 \\
\hline 40 & 183.15 & 25.75 & 379.5210468 & 87 & 192.12 & 23.45 & 339.2001838 \\
\hline 41 & 183.71 & 25.58 & 377.434191 & 88 & 192.17 & 23.42 & 338.9123893 \\
\hline 42 & 184.32 & 25.41 & 375.1153232 & 89 & 192.22 & 23.42 & 338.6234438 \\
\hline 43 & 184.73 & 25.28 & 373.5284673 & 91 & 192.2 & 23.42 & 338.739161 \\
\hline 44 & 185.32 & 25.12 & 371.2026785 & 92 & 192.17 & 23.42 & 338.9123893 \\
\hline 45 & 185.83 & 24.98 & 369.1497276 & 93 & 192.17 & 23.42 & 338.9123893 \\
\hline 46 & 186.21 & 24.87 & 367.5929324 & 94 & 192.19 & 23.42 & 338.79695 \\
\hline 47 & 186.69 & 24.74 & 365.5914417 & 95 & 192.18 & 23.42 & 338.8546928 \\
\hline 48 & 187.21 & 24.6 & 363.3764272 & 96 & 192.22 & 23.42 & 338.6234438 \\
\hline
\end{tabular}


Zara $800 \mathrm{~m}$ away from the shoreline

\begin{tabular}{|c|c|c|c|c|c|c|c|}
\hline $\begin{array}{c}\text { Depth } \\
{[\mathrm{m}]}\end{array}$ & $\begin{array}{c}\text { E.C. } \\
{[\mathrm{mS} / \mathrm{cm}]}\end{array}$ & $\begin{array}{c}\mathrm{T} . \\
{\left[\mathrm{C}^{\circ}\right]}\end{array}$ & $\begin{array}{l}\text { TDS } \\
\text { [g/l] }\end{array}$ & $\begin{array}{l}\text { Depth } \\
{[\mathrm{m}]}\end{array}$ & $\begin{array}{c}\text { E.C. } \\
{[\mathrm{mS} / \mathrm{cm}]}\end{array}$ & $\begin{array}{c}\mathrm{T} . \\
{\left[\mathrm{C}^{\circ}\right]}\end{array}$ & $\begin{array}{l}\text { TDS } \\
{[\mathrm{g} / \mathrm{ll}]}\end{array}$ \\
\hline 1 & 198.4 & 30.72 & 271.9371294 & 48 & 189.93 & 23.88 & 350.8457087 \\
\hline 2 & 198.4 & 31.08 & 271.9371294 & 49 & 190.05 & 23.85 & 350.2496261 \\
\hline 3 & 197.04 & 31.4 & 300.7417472 & 50 & 190.16 & 23.84 & 349.699458 \\
\hline 4 & 195.83 & 31.65 & 313.243962 & 51 & 190.24 & 23.81 & 349.297035 \\
\hline 5 & 195.96 & 31.85 & 312.0661282 & 52 & 190.58 & 23.79 & 347.5644073 \\
\hline 6 & 194.9 & 32.01 & 320.929402 & 53 & 190.69 & 23.77 & 346.9958505 \\
\hline 7 & 193.71 & 32.15 & 329.4051007 & 54 & 190.79 & 23.75 & 346.475466 \\
\hline 8 & 192.18 & 32.25 & 338.8546928 & 55 & 190.88 & 23.72 & 346.0042016 \\
\hline 9 & 185.65 & 32.34 & 369.8789614 & 56 & 190.96 & 23.71 & 345.5829373 \\
\hline 10 & 181.15 & 32.37 & 386.6782402 & 57 & 190.93 & 23.7 & 345.7411744 \\
\hline 11 & 169.31 & 32.2 & 422.4532015 & 58 & 191.07 & 23.68 & 345 \\
\hline 12 & 166.21 & 31.8 & 430.5348386 & 59 & 191.18 & 23.66 & 344.4126919 \\
\hline 13 & 166.86 & 31.25 & 428.8736675 & 60 & 191.3 & 23.63 & 343.76689 \\
\hline 14 & 167.58 & 30.78 & 427.0135129 & 61 & 191.43 & 23.6 & 343.0611109 \\
\hline 15 & 168.92 & 30.16 & 423.4928266 & 62 & 191.56 & 23.58 & 342.3487503 \\
\hline 16 & 170.61 & 29.55 & 418.9365294 & 63 & 191.63 & 23.56 & 341.96238 \\
\hline 17 & 171.92 & 29.11 & 415.3086676 & 64 & 191.67 & 23.55 & 341.7407042 \\
\hline 18 & 173.63 & 28.58 & 410.4353853 & 65 & 191.81 & 23.52 & 340.9596303 \\
\hline 19 & 175.18 & 28.11 & 405.8707535 & 66 & 191.82 & 23.51 & 340.9035248 \\
\hline 20 & 176.29 & 27.79 & 402.5076685 & 67 & 191.9 & 23.5 & 340.4531454 \\
\hline 21 & 177.52 & 27.42 & 398.6809757 & 68 & 191.93 & 23.49 & 340.2835428 \\
\hline 22 & 178.38 & 27.16 & 395.9381295 & 69 & 191.97 & 23.49 & 340.0567962 \\
\hline 23 & 179.42 & 26.85 & 392.5413839 & 70 & 191.98 & 23.48 & 340 \\
\hline 24 & 180.35 & 26.59 & 389.4243322 & 71 & 191.98 & 23.47 & 340 \\
\hline 25 & 181.13 & 26.36 & 386.7476579 & 72 & 192 & 23.47 & 339.8862755 \\
\hline 26 & 181.62 & 26.2 & 385.035206 & 73 & 192.01 & 23.46 & 339.8293469 \\
\hline 27 & 182.37 & 25.98 & 382.3650293 & 74 & 192.04 & 23.46 & 339.6582948 \\
\hline 28 & 182.99 & 25.8 & 380.1102405 & 75 & 192.03 & 23.46 & 339.7153567 \\
\hline 29 & 183.39 & 25.67 & 378.6314429 & 76 & 192.06 & 23.45 & 339.544037 \\
\hline 30 & 184.01 & 25.5 & 376.2998936 & 77 & 192.1 & 23.45 & 339.3149824 \\
\hline 31 & 184.62 & 25.33 & 373.9565129 & 78 & 192.09 & 23.44 & 339.3723137 \\
\hline 32 & 184.96 & 25.2 & 372.6278755 & 79 & 192.12 & 23.44 & 339.2001838 \\
\hline 33 & 185.58 & 25.05 & 370.1611646 & 80 & 192.11 & 23.44 & 339.2576058 \\
\hline 34 & 185.97 & 24.94 & 368.5789383 & 81 & 192.14 & 23.44 & 339.0852033 \\
\hline 35 & 186.44 & 24.81 & 366.638885 & 82 & 192.16 & 23.44 & 338.9700399 \\
\hline 36 & 186.94 & 24.67 & 364.5327884 & 83 & 192.16 & 23.43 & 338.9700399 \\
\hline 37 & 187.32 & 24.57 & 362.9013336 & 84 & 192.15 & 23.43 & 339.0276445 \\
\hline 38 & 187.66 & 24.47 & 361.4178027 & 85 & 192.14 & 23.44 & 339.0852033 \\
\hline 39 & 188.05 & 24.36 & 359.6869751 & 86 & 192.14 & 23.43 & 339.0852033 \\
\hline 40 & 188.34 & 24.29 & 358.3787766 & 87 & 192.16 & 23.43 & 338.9700399 \\
\hline 41 & 188.7 & 24.2 & 356.7283739 & 88 & 192.17 & 23.44 & 338.9123893 \\
\hline 42 & 188.98 & 24.14 & 355.423513 & 89 & 192.15 & 23.43 & 339.0276445 \\
\hline 43 & 189.14 & 24.08 & 354.6691919 & 90 & 192.16 & 23.43 & 338.9700399 \\
\hline 44 & 189.33 & 24.03 & 353.7649509 & 91 & 192.17 & 23.42 & 338.9123893 \\
\hline 45 & 189.55 & 23.99 & 352.7060633 & 92 & 192.17 & 23.42 & 338.9123893 \\
\hline 46 & 189.68 & 23.95 & 352.0741865 & 93 & 192.17 & 23.43 & 338.9123893 \\
\hline 47 & 189.84 & 23.91 & 351.2900152 & 94 & 192.18 & 23.43 & 338.8546928 \\
\hline
\end{tabular}


Wadi Mujeb $400 \mathrm{~m}$ away from the shoreline

\begin{tabular}{|c|c|c|c|c|c|c|c|}
\hline $\begin{array}{c}\text { Depth } \\
{[\mathrm{m}]}\end{array}$ & $\begin{array}{c}\text { E.C. } \\
{[\mathrm{mS} / \mathrm{cm}]}\end{array}$ & $\begin{array}{c}\mathrm{T} . \\
{\left[\mathrm{C}^{\circ}\right]}\end{array}$ & $\begin{array}{l}\text { TDS } \\
{[\mathrm{g} / \mathrm{l}]}\end{array}$ & $\begin{array}{l}\text { Depth } \\
{[\mathrm{m}]}\end{array}$ & $\begin{array}{c}\text { E.C. } \\
{[\mathrm{mS} / \mathrm{cm}]}\end{array}$ & $\begin{array}{c}\mathrm{T} . \\
{\left[\mathrm{C}^{\circ}\right]}\end{array}$ & $\begin{array}{l}\text { TDS } \\
{[\mathrm{g} / \mathrm{l}]}\end{array}$ \\
\hline 1 & 186.4 & 34.6 & 366.81 & 44 & 186.66 & 25.02 & 365.72 \\
\hline 2 & 186.37 & 34.51 & 366.93 & 45 & 187.09 & 24.9 & 363.89 \\
\hline 3 & 186.74 & 34.39 & 365.38 & 46 & 187.21 & 24.87 & 363.38 \\
\hline 4 & 187.02 & 34.29 & 364.19 & 47 & 187.49 & 24.8 & 362.16 \\
\hline 5 & 187.14 & 34.24 & 363.68 & 48 & 187.57 & 24.77 & 361.81 \\
\hline 6 & 187.29 & 34.19 & 363.03 & 49 & 187.87 & 24.68 & 360.49 \\
\hline 7 & 187.35 & 34.14 & 362.77 & 50 & 187.89 & 24.68 & 360.4 \\
\hline 8 & 187.61 & 34.09 & 361.64 & 51 & 188.19 & 24.59 & 359.06 \\
\hline 9 & 187.41 & 34.04 & 362.51 & 52 & 188.42 & 24.52 & 358.01 \\
\hline 10 & 187.36 & 34 & 362.73 & 53 & 188.53 & 24.49 & 357.51 \\
\hline 11 & 182.31 & 33.94 & 382.58 & 54 & 188.65 & 24.46 & 356.96 \\
\hline 12 & 178.98 & 33.72 & 393.99 & 55 & 188.95 & 24.39 & 355.56 \\
\hline 13 & 176.82 & 33.29 & 400.87 & 56 & 189.05 & 24.36 & 355.09 \\
\hline 14 & 175.58 & 33.16 & 404.67 & 57 & 189.31 & 24.3 & 353.86 \\
\hline 15 & 173.57 & 32.71 & 410.61 & 58 & 189.37 & 24.28 & 353.57 \\
\hline 16 & 169.94 & 32.55 & 420.76 & 59 & 189.62 & 24.22 & 352.37 \\
\hline 17 & 166.76 & 32.06 & 429.13 & 60 & 189.71 & 24.19 & 351.93 \\
\hline 18 & 167.38 & 31.8 & 427.53 & 61 & 189.93 & 24.14 & 350.85 \\
\hline 19 & 169.23 & 31.15 & 422.67 & 62 & 190.02 & 24.12 & 350.4 \\
\hline 20 & 169.93 & 30.89 & 420.79 & 63 & 190.28 & 24.06 & 349.1 \\
\hline 21 & 171.25 & 30.29 & 417.18 & 64 & 190.32 & 24.04 & 348.89 \\
\hline 22 & 171.81 & 30.07 & 415.62 & 65 & 190.48 & 24.01 & 348.08 \\
\hline 23 & 173.18 & 29.25 & 411.73 & 66 & 190.59 & 23.98 & 347.51 \\
\hline 24 & 173.41 & 29.16 & 411.07 & 67 & 190.8 & 23.93 & 346.42 \\
\hline 25 & 175.83 & 28.41 & 403.91 & 68 & 190.88 & 23.91 & 346 \\
\hline 26 & 175.99 & 28.33 & 403.42 & 69 & 191.18 & 23.84 & 344.41 \\
\hline 27 & 177.79 & 27.72 & 397.83 & 70 & 191.13 & 23.85 & 344.68 \\
\hline 28 & 178.34 & 27.57 & 396.07 & 71 & 191.45 & 23.79 & 342.95 \\
\hline 29 & 179.44 & 27.25 & 392.48 & 72 & 191.49 & 23.78 & 342.73 \\
\hline 30 & 179.82 & 27.12 & 391.21 & 73 & 191.66 & 23.75 & 341.8 \\
\hline 31 & 180.48 & 26.85 & 388.98 & 74 & 191.74 & 23.73 & 341.35 \\
\hline 32 & 180.78 & 26.75 & 387.96 & 75 & 191.95 & 23.69 & 340.17 \\
\hline 33 & 181.98 & 26.35 & 383.76 & 76 & 192.01 & 23.67 & 339.83 \\
\hline 34 & 182.04 & 26.32 & 383.55 & 77 & 192.26 & 23.62 & 338.39 \\
\hline 35 & 182.94 & 26.05 & 380.29 & 78 & 192.32 & 23.61 & 338.04 \\
\hline 36 & 183.24 & 25.96 & 379.19 & 79 & 192.35 & 23.6 & 337.87 \\
\hline 37 & 184.06 & 25.7 & 376.11 & 80 & 192.4 & 23.59 & 337.57 \\
\hline 38 & 184.61 & 25.61 & 374 & 81 & 192.44 & 23.58 & 337.34 \\
\hline 39 & 184.78 & 25.47 & 373.33 & 82 & 192.51 & 23.57 & 336.92 \\
\hline 40 & 185.15 & 25.41 & 371.88 & 83 & 192.58 & 23.55 & 336.51 \\
\hline 41 & 185.83 & 25.24 & 369.15 & 84 & 192.61 & 23.55 & 336.33 \\
\hline 42 & 185.89 & 25.22 & 368.91 & 85 & 192.74 & 23.52 & 335.55 \\
\hline \multirow[t]{2}{*}{43} & 186.62 & 25.03 & 365.89 & 86 & 192.77 & 23.51 & 335.36 \\
\hline & & & & 87 & 192.76 & 23.51 & 335.43 \\
\hline
\end{tabular}




\section{APPENDIX III}

RADON RESULTS IN ALL THE STATIONS 
Radon -222 measurements

\begin{tabular}{|c|c|c|c|c|}
\hline Area Name & $\begin{array}{l}\mathrm{Rn}-222 \\
(\mathrm{~Bq} / \mathrm{l})\end{array}$ & \begin{tabular}{|l}
$\begin{array}{l}\text { Sample } \\
\text { direction }\end{array}$ \\
\end{tabular} & Day & Sample location \\
\hline Mujeb-2m & \multicolumn{2}{|r|}{0.64 Virtical } & \multicolumn{2}{|c|}{ Jul-05 $S_{\mathrm{rn} 4^{-}} 20 \mathrm{~m}$ from the shoreline } \\
\hline Mujeb-4m & \multicolumn{2}{|r|}{0.99 Virtical } & \multicolumn{2}{|c|}{ Jul-05 $S_{\mathrm{rn} 4^{-}} 20 \mathrm{~m}$ from the shoreline } \\
\hline Mujeb-7m & \multicolumn{2}{|r|}{0.67 Virtical } & \multicolumn{2}{|c|}{ Jul-05 $S_{r n 4^{-}} 20 \mathrm{~m}$ from the shoreline } \\
\hline Mujeb-12m & \multicolumn{2}{|r|}{ 1.78 Virtical } & \multicolumn{2}{|c|}{ Jul-05 $S_{\mathrm{rn} 4}-20 \mathrm{~m}$ from the shoreline } \\
\hline Mujeb-24m & \multicolumn{2}{|r|}{0.82 Virtical } & \multicolumn{2}{|c|}{ Jul-05 $S_{\mathrm{rn} 4^{-}} 20 \mathrm{~m}$ from the shoreline } \\
\hline Zara-2m & \multicolumn{2}{|r|}{ 1.29Virtical } & \multicolumn{2}{|c|}{ Jul-05 $S_{\mathrm{rn}^{-}}-25 \mathrm{~m}$ from the shoreline } \\
\hline Zara-4m & \multicolumn{2}{|r|}{ 1.53Virtical } & \multicolumn{2}{|c|}{ Jul-05 $S_{\mathrm{rn} 3}-25 \mathrm{~m}$ from the shoreline } \\
\hline Zara-7m & \multicolumn{2}{|r|}{ 1.69Virtical } & \multicolumn{2}{|c|}{ Jul-05 $S_{r n 3^{-}} 25 \mathrm{~m}$ from the shoreline } \\
\hline Zara-12 & \multicolumn{2}{|r|}{ 1.78 Virtical } & \multicolumn{2}{|c|}{ Jul-05 $S_{\mathrm{rn} 3^{-}} 25 \mathrm{~m}$ from the shoreline } \\
\hline Zara-24m & \multicolumn{2}{|r|}{1.00 Virtical } & \multicolumn{2}{|c|}{ Jul-05 $S_{\mathrm{rn3}^{-}} 25 \mathrm{~m}$ from the shoreline } \\
\hline NAVI-4m & \multicolumn{2}{|r|}{ 1.39 Perbendicular } & \multicolumn{2}{|c|}{ Jul-05500 m south $S_{\mathrm{rn} 3}-40 \mathrm{~m}$ from $\mathrm{SH}$} \\
\hline NAVI-4m & \multicolumn{2}{|r|}{ 2.10Perbendicular } & \multicolumn{2}{|c|}{ Jul-05 $500 \mathrm{~m}$ south $\mathrm{S}_{\mathrm{rn3}^{-}} 20 \mathrm{~m}$ from $\mathrm{SH}$} \\
\hline NAVI-4m & \multicolumn{2}{|r|}{ 1.90 Perbendicular } & \multicolumn{2}{|c|}{ Jul-05500 m south $\mathrm{S}_{\mathrm{rn} 3}-30 \mathrm{~m}$ from $\mathrm{SH}$} \\
\hline Zara-12m & & 1.07Parallel & Jul-05 & $5 \mathrm{~S}_{\mathrm{rn}^{-}}-50 \mathrm{~m}$ from $\mathrm{SH}$ \\
\hline Zara-12m & & 2.52 Parallel & Jul-05 & $5150 \mathrm{~m}$ north $\mathrm{S}_{\mathrm{rn3}}-15-20 \mathrm{~m}$ from $\mathrm{SH}$ \\
\hline Zara-12m & & 1.93 Parallel & Jul-05 & $5150 \mathrm{~m}$ north $\mathrm{S}_{\mathrm{rn} 3^{-}} 30 \mathrm{~m}$ from SH \\
\hline Zara-12m & & 1.56 Parallel & Jul-05 & $5500 \mathrm{~m}$ north $\mathrm{S}_{\mathrm{rn3} 3^{-}}-15-20 \mathrm{~m}$ from SH \\
\hline Zara-12m & & 1.23 Parallel & Jul-05 & $5500 \mathrm{~m}$ north $\mathrm{S}_{\mathrm{rn3}}-50 \mathrm{~m}$ from SH \\
\hline Navi-2m & & 2.24Perbindicular & Jul-05 & $5500 \mathrm{~m}$ south $\mathrm{S}_{\mathrm{rn} 3^{-}} 20 \mathrm{~m}$ from $\mathrm{SH}$ \\
\hline Navi-12m & & 1.91 Perbindicular & Jul-05 & $5500 \mathrm{~m}$ south $\mathrm{S}_{\mathrm{rn} 3^{-}}-40 \mathrm{~m}$ from $\mathrm{SH}$ \\
\hline south-navi-12m & & 2.70Perbendicular & Jul-05 & 51000 south $\mathrm{S}_{\mathrm{rn3}}-20 \mathrm{~m}$ from $\mathrm{SH}$ \\
\hline south-navi-12m & & 2.20 Perbendicular & Jul-05 & 51000 south $\mathrm{S}_{\mathrm{rn3}^{-}}-50 \mathrm{~m}$ from $\mathrm{SH}$ \\
\hline south-navi-12m & & 1.44Perbendicular & Jul-05 & 51000 south $S_{\mathrm{rn}^{-}}-200$ from $\mathrm{SH}$ \\
\hline south-navi-12m & & 2.79Perbendicular & Jul-05 & $52500 \mathrm{~m}$ south $\mathrm{S}_{\mathrm{rn} 3^{-}} 20 \mathrm{~m}$ fom $\mathrm{SH}$ \\
\hline Z.Ma'in-2m & & 0.87 Virtical & Jul-05 & $5 S_{\mathrm{rn2}^{-}}-25 \mathrm{~m}$ from the shoreline \\
\hline Z.Ma'in- $4 \mathrm{~m}$ & & 2.08 Virtical & Jul-05 & $5 S_{\mathrm{rn2}^{-}}-25 \mathrm{~m}$ from the shoreline \\
\hline Z.Ma'in-7m & & 2.18 Virtical & Jul-05 & $5 S_{\mathrm{rn2}^{-}} 25 \mathrm{~m}$ from the shoreline \\
\hline Z. Ma'in-12m & & 1.87 Virtical & Jul-05 & $5 S_{\mathrm{rn2}^{-}}-25 \mathrm{~m}$ from the shoreline \\
\hline Z. Ma'in-25m & & 1.31 Virtical & Jul-05 & $5 S_{\mathrm{rn2}^{-}}-25 \mathrm{~m}$ from the shoreline \\
\hline Zma'in-4m & & 2.14 PARALLEL & Jul-05 & $5 \mathrm{~S}_{\mathrm{rn2}-10 \mathrm{~m} \text { from the shoreline }}$ \\
\hline Zma'in-4m & & 2.06PARALLEL & Jul-05 & $5 \mathrm{~S}_{\mathrm{rn2}-}-40 \mathrm{~m}$ from the shoreline \\
\hline Zma'in-4m & & 1.96PARALLEL & Jul-05 & $5300 \mathrm{~m}$ north $\mathrm{S}_{\mathrm{rn2}}-10 \mathrm{~m}$ from the $\mathrm{SH}$ \\
\hline Zma'in-4m & & 0.68PARALLEL & Jul-05 & $5300 \mathrm{~m}$ north $\mathrm{S}_{\mathrm{rn2}}-40 \mathrm{~m}$ from the $\mathrm{SH}$ \\
\hline Zma'in-4m & & 2.22 PARALLEL & Jul-05 & $5800 \mathrm{~m}$ north $\mathrm{S}_{\mathrm{rn2}}-10 \mathrm{~m}$ from the $\mathrm{SH}$ \\
\hline North area-2m & & 1.14 vertical & Jul-05 & $5 S_{\mathrm{rn} 1}-15-20 \mathrm{~m}$ from $\mathrm{SH}$ \\
\hline North area- $4 \mathrm{~m}$ & & 1.89 vertical & Jul-05 & $5 S_{\mathrm{rn} 1}-15-20 \mathrm{~m}$ from $\mathrm{SH}$ \\
\hline North area-7m & & 1.58 vertical & Jul-05 & $5 S_{\mathrm{rn} 1}-15-20 \mathrm{~m}$ from $\mathrm{SH}$ \\
\hline North area- $12 \mathrm{~m}$ & & 2.52 vertical & Jul-05 & $5 S_{\mathrm{rn} 1}-15-20 \mathrm{~m}$ from $\mathrm{SH}$ \\
\hline North area-20m & & 1.74 vertical & Jul-05 & $5 S_{\mathrm{rn} 1}-20 \mathrm{~m}$ from $\mathrm{SH}$ \\
\hline North area-12m & & 2.15 Perbendicular & Jul-05 & $54500 \mathrm{~m}$ south $\mathrm{S}_{\mathrm{rn} 1}-60 \mathrm{~m}$ from $\mathrm{SH}$ \\
\hline North area-20m & & 1.30 Perbendicular & Jul-05 & $54500 m$ south $S_{\mathrm{rn} 1}-60 \mathrm{~m}$ from $\mathrm{SH}$ \\
\hline
\end{tabular}




\begin{tabular}{|c|c|c|}
\hline North area-12m & 1.44 Perbendicular & Jul-05 $4500 \mathrm{~m}$ south $\mathrm{S}_{\mathrm{rn} 1}-200 \mathrm{~m}$ from $\mathrm{SH}$ \\
\hline North area- $12 \mathrm{~m}$ & 1.31 Perbendicular & Jul-05 $4500 \mathrm{~m}$ south $\mathrm{S}_{\mathrm{rn} 1}-300 \mathrm{~m}$ from $\mathrm{SH}$ \\
\hline North area- $12 \mathrm{~m}$ & 1.15 Perbendicular & Jul- $054500 m$ south $S_{r n 1}-700 m$ from $S H$ \\
\hline \begin{tabular}{|l} 
conference \\
palace-12m
\end{tabular} & 2.19Perbendicular & Jul-05800m north $\mathrm{S}_{\mathrm{rn} 1 .} \cdot-50 \mathrm{~m}$ from $\mathrm{SH}$ \\
\hline $\begin{array}{l}\text { conference } \\
\text { palace-20m }\end{array}$ & 1.23 Perbendicular & Jul-05800 north $S_{\mathrm{rn} 1}-200 \mathrm{~m}$ from SH \\
\hline $\begin{array}{l}\text { conference } \\
\text { palace-12m }\end{array}$ & 1.95 Perbendicular & Jul-05800m north $S_{r n 1^{-}} 300 m$ from $\mathrm{SH}$ \\
\hline $\begin{array}{l}\text { conference } \\
\text { palace-12m }\end{array}$ & 2.14 Perbendicular & Jul-05 $1000 m$ north $S_{r n 1}-200 m$ from SH \\
\hline
\end{tabular}




\section{APPENDIX IV}

\section{ANOMALIES OF THE ELECTRICAL RADIATION (EMR)}


North East Date Elevation (m)

\begin{tabular}{|c|c|c|c|}
\hline 31.727131 & 35.588908 & 29-dec-05 & -418 \\
\hline 31.728626 & 35.589044 & $29-$ dec-05 & -421 \\
\hline 31.729329 & 35.589092 & 29-dec-05 & -420 \\
\hline 31.729364 & 35.589134 & 29-dec-05 & -417 \\
\hline 31.732338 & 35.590058 & 29-dec-05 & -417 \\
\hline 31.733003 & 35.590334 & 29-dec-05 & -420 \\
\hline 31.733337 & 35.590427 & $29-$ dec-05 & -414 \\
\hline 31.735135 & 35.590440 & 29-dec-05 & -417 \\
\hline 31.736960 & 35.590535 & 29-dec-05 & -418 \\
\hline 31.737092 & 35.590832 & 29-dec-05 & -416 \\
\hline 31.737600 & 35.591111 & 29-dec-05 & -419 \\
\hline 31.740407 & 35.592425 & $29-$ dec-05 & -415 \\
\hline 31.740717 & 35.592546 & 29-dec-05 & -414 \\
\hline 31.743493 & 35.592405 & 29-dec-05 & -409 \\
\hline 31.743914 & 35.592292 & 29-dec-05 & -413 \\
\hline 31.746417 & 35.590838 & 29-dec-05 & -411 \\
\hline 31.746986 & 35.590599 & 29-dec-05 & -412 \\
\hline 31.748608 & 35.589117 & 29-dec-05 & -412 \\
\hline 31.748607 & 35.589117 & 29-dec-05 & -412 \\
\hline 31.750979 & 35.587228 & 29-dec-05 & -410 \\
\hline 31.750789 & 35.585118 & 29-dec-05 & -412 \\
\hline 31.751724 & 35.583490 & $29-$ dec-05 & -417 \\
\hline 31.752436 & 35.583384 & 29-dec-05 & -418 \\
\hline 31.754745 & 35.582497 & 29-dec-05 & -420 \\
\hline 31.755484 & 35.582021 & 29-dec-05 & -415 \\
\hline 31.756997 & 35.581641 & 29-dec-05 & -409 \\
\hline 31.757293 & 35.581570 & 29-dec-05 & -411 \\
\hline 31.757426 & 35.581484 & 29-dec-05 & -412 \\
\hline 31.757945 & 35.580675 & $29-$ dec-05 & -415 \\
\hline 31.758040 & 35.579938 & $29-$ dec-05 & -414 \\
\hline 31.758805 & 35.578721 & 29-dec-05 & -417 \\
\hline 31.759028 & 35.578277 & 29-dec-05 & -418 \\
\hline 31.761104 & 35.576475 & 29-dec-05 & -419 \\
\hline 31.579778 & 35.554578 & $01 / 05 / 2006$ & -418 \\
\hline 31.580321 & 35.554602 & $01 / 05 / 2006$ & -418 \\
\hline 31.580346 & 35.554542 & $01 / 05 / 2006$ & -420 \\
\hline 31.580464 & 35.554339 & $01 / 05 / 2006$ & -420 \\
\hline 31.580468 & 35.554270 & $01 / 05 / 2006$ & -418 \\
\hline 31.580619 & 35.554391 & $01 / 05 / 2006$ & -418 \\
\hline 31.580833 & 35.554541 & $01 / 05 / 2006$ & -419 \\
\hline 31.580876 & 35.554577 & $01 / 05 / 2006$ & -418 \\
\hline 31.580873 & 35.554632 & $01 / 05 / 2006$ & -418 \\
\hline 31.580989 & 35.554686 & $01 / 05 / 2006$ & -418 \\
\hline 31.580972 & 35.554589 & $01 / 05 / 2006$ & -416 \\
\hline 31.581114 & 35.554622 & $01 / 05 / 2006$ & -417 \\
\hline 31.581293 & 35.554567 & $01 / 05 / 2006$ & -415 \\
\hline 31.581328 & 35.554560 & $01 / 05 / 2006$ & -415 \\
\hline 31.581298 & 35.554715 & $01 / 05 / 2006$ & -412 \\
\hline 31.581422 & 35.554584 & $01 / 05 / 2006$ & -413 \\
\hline 31.581450 & 35.554549 & $01 / 05 / 2006$ & -415 \\
\hline 31.581656 & 35.554437 & $01 / 05 / 2006$ & -415 \\
\hline 31.581725 & 35.554441 & $01 / 05 / 2006$ & -415 \\
\hline 31.582203 & 35.554392 & $01 / 05 / 2006$ & -416 \\
\hline 31.582204 & 35.554393 & $01 / 05 / 2006$ & -416 \\
\hline 31.582109 & 35.554256 & $01 / 05 / 2006$ & -414 \\
\hline
\end{tabular}


North East Date Elevation (m)

\begin{tabular}{|c|c|c|c|}
\hline 31.582152 & 35.554220 & $01 / 05 / 2006$ & -415 \\
\hline 31.582248 & 35.554192 & $01 / 05 / 2006$ & -415 \\
\hline 31.582283 & 35.554202 & $01 / 05 / 2006$ & -415 \\
\hline 31.582284 & 35.554209 & $01 / 05 / 2006$ & -414 \\
\hline 31.582518 & 35.554136 & $01 / 05 / 2006$ & -415 \\
\hline 31.582557 & 35.554138 & 01/05/2006 & -416 \\
\hline 31.582580 & 35.554136 & $01 / 05 / 2006$ & -416 \\
\hline 31.582866 & 35.554010 & $01 / 05 / 2006$ & -417 \\
\hline 31.582879 & 35.553995 & $01 / 05 / 2006$ & -417 \\
\hline 31.583362 & 35.554118 & $01 / 05 / 2006$ & -420 \\
\hline 31.583243 & 35.554114 & $01 / 05 / 2006$ & -417 \\
\hline 31.583674 & 35.554244 & 01/05/2006 & -417 \\
\hline 31.584061 & 35.554303 & $01 / 05 / 2006$ & -417 \\
\hline 31.584253 & 35.554228 & $01 / 05 / 2006$ & -417 \\
\hline 31.584539 & 35.554194 & $01 / 05 / 2006$ & -417 \\
\hline 31.584629 & 35.554402 & $01 / 05 / 2006$ & -394 \\
\hline 31.584678 & 35.554373 & $01 / 05 / 2006$ & -410 \\
\hline 31.584813 & 35.554338 & $01 / 05 / 2006$ & -413 \\
\hline 31.584734 & 35.554330 & $01 / 05 / 2006$ & -419 \\
\hline 31.584835 & 35.554219 & $01 / 05 / 2006$ & -415 \\
\hline 31.584810 & 35.554319 & $01 / 05 / 2006$ & -414 \\
\hline 31.584884 & 35.554295 & $01 / 05 / 2006$ & -415 \\
\hline 31.584767 & 35.554335 & $01 / 05 / 2006$ & -414 \\
\hline 31.584820 & 35.554334 & $01 / 05 / 2006$ & -413 \\
\hline 31.585025 & 35.554323 & $01 / 05 / 2006$ & -414 \\
\hline 31.585315 & 35.554464 & $01 / 05 / 2006$ & -412 \\
\hline 31.585591 & 35.554763 & $01 / 05 / 2006$ & -412 \\
\hline 31.585431 & 35.554665 & $01 / 05 / 2006$ & -405 \\
\hline 31.585578 & 35.554815 & 01/05/2006 & -405 \\
\hline 31.585610 & 35.554697 & $01 / 05 / 2006$ & -405 \\
\hline 31.585783 & 35.554768 & $01 / 05 / 2006$ & -406 \\
\hline 31.585906 & 35.554781 & $01 / 05 / 2006$ & -409 \\
\hline 31.586002 & 35.554870 & $01 / 05 / 2006$ & -413 \\
\hline 31.586167 & 35.555015 & $01 / 05 / 2006$ & -414 \\
\hline 31.586228 & 35.555064 & 01/05/2006 & -414 \\
\hline 31.586429 & 35.555200 & $01 / 05 / 2006$ & -415 \\
\hline 31.586833 & 35.555460 & $01 / 05 / 2006$ & -414 \\
\hline 31.586927 & 35.555584 & $01 / 05 / 2006$ & -416 \\
\hline 31.586992 & 35.555630 & $01 / 05 / 2006$ & -419 \\
\hline 31.587248 & 35.555925 & $01 / 05 / 2006$ & -419 \\
\hline 31.587300 & 35.555965 & $01 / 05 / 2006$ & -420 \\
\hline 31.587421 & 35.556049 & $01 / 05 / 2006$ & -420 \\
\hline 31.587524 & 35.556189 & $01 / 05 / 2006$ & -420 \\
\hline 31.587581 & 35.556231 & $01 / 05 / 2006$ & -420 \\
\hline 31.587612 & 35.556278 & $01 / 05 / 2006$ & -420 \\
\hline 31.587702 & 35.556372 & $01 / 05 / 2006$ & -420 \\
\hline 31.587811 & 35.556470 & $01 / 05 / 2006$ & -420 \\
\hline 31.587854 & 35.556520 & $01 / 05 / 2006$ & -420 \\
\hline 31.587867 & 35.556570 & $01 / 05 / 2006$ & -420 \\
\hline 31.587953 & 35.556692 & $01 / 05 / 2006$ & -418 \\
\hline 31.588014 & 35.556766 & $01 / 05 / 2006$ & -418 \\
\hline 31.588130 & 35.556860 & $01 / 05 / 2006$ & -419 \\
\hline 31.588839 & 35.557204 & $01 / 05 / 2006$ & -419 \\
\hline 31.588817 & 35.557129 & $01 / 05 / 2006$ & -420 \\
\hline 31.588790 & 35.557126 & $01 / 05 / 2006$ & -420 \\
\hline 31.588847 & 35.557145 & $01 / 05 / 2006$ & -420 \\
\hline 31.588962 & 35.557184 & $01 / 05 / 2006$ & -420 \\
\hline
\end{tabular}




\begin{tabular}{|c|c|c|c|}
\hline North & East & Date & evation (m) \\
\hline 31.589057 & 35.557161 & $01 / 05 / 2006$ & -420 \\
\hline 31.589311 & 35.557163 & $01 / 05 / 2006$ & -420 \\
\hline 31.589478 & 35.557132 & $01 / 05 / 2006$ & -420 \\
\hline 31.589500 & 35.557131 & $01 / 05 / 2006$ & -420 \\
\hline 31.589706 & 35.557149 & $01 / 05 / 2006$ & -420 \\
\hline 31.589866 & 35.557152 & $01 / 05 / 2006$ & -420 \\
\hline 31.589965 & 35.557132 & $01 / 05 / 2006$ & -420 \\
\hline 31.590231 & 35.557092 & $01 / 05 / 2006$ & -420 \\
\hline 31.590282 & 35.557087 & $01 / 05 / 2006$ & -420 \\
\hline 31.590607 & 35.556920 & $01 / 05 / 2006$ & -420 \\
\hline 31.590693 & 35.556975 & $01 / 05 / 2006$ & -420 \\
\hline 31.590996 & 35.557024 & $01 / 05 / 2006$ & -420 \\
\hline 31.591417 & 35.557233 & $01 / 05 / 2006$ & -408 \\
\hline 31.591667 & 35.557360 & $01 / 05 / 2006$ & -405 \\
\hline 31.591982 & 35.557375 & $01 / 05 / 2006$ & -410 \\
\hline 31.592323 & 35.557387 & $01 / 05 / 2006$ & -409 \\
\hline 31.592416 & 35.557368 & $01 / 05 / 2006$ & -410 \\
\hline 31.592522 & 35.557359 & $01 / 05 / 2006$ & -413 \\
\hline 31.592861 & 35.557336 & $01 / 05 / 2006$ & -416 \\
\hline 31.592969 & 35.557375 & $01 / 05 / 2006$ & -417 \\
\hline 31.593020 & 35.557387 & $01 / 05 / 2006$ & -417 \\
\hline 31.593138 & 35.557392 & $01 / 05 / 2006$ & -417 \\
\hline 31.593209 & 35.557401 & $01 / 05 / 2006$ & -417 \\
\hline 31.593460 & 35.557373 & $01 / 05 / 2006$ & -415 \\
\hline 31.593496 & 35.557367 & $01 / 05 / 2006$ & -415 \\
\hline 31.593661 & 35.557445 & $01 / 05 / 2006$ & -416 \\
\hline 31.593676 & 35.557441 & $01 / 05 / 2006$ & -417 \\
\hline 31.593819 & 35.557547 & $01 / 05 / 2006$ & -416 \\
\hline 31.593883 & 35.557558 & $01 / 05 / 2006$ & -416 \\
\hline 31.594172 & 35.557667 & $01 / 05 / 2006$ & -416 \\
\hline 31.594329 & 35.557684 & $01 / 05 / 2006$ & -417 \\
\hline 31.594528 & 35.557705 & $01 / 05 / 2006$ & -418 \\
\hline 31.594737 & 35.557721 & $01 / 05 / 2006$ & -419 \\
\hline 31.595422 & 35.557736 & $01 / 05 / 2006$ & -417 \\
\hline 31.595448 & 35.557735 & $01 / 05 / 2006$ & -417 \\
\hline 31.595721 & 35.557739 & $01 / 05 / 2006$ & -413 \\
\hline 31.595755 & 35.557728 & $01 / 05 / 2006$ & -416 \\
\hline 31.595953 & 35.557668 & $01 / 05 / 2006$ & -415 \\
\hline 31.596225 & 35.557588 & $01 / 05 / 2006$ & -415 \\
\hline 31.596447 & 35.557562 & $01 / 05 / 2006$ & -420 \\
\hline 31.596603 & 35.557664 & $01 / 05 / 2006$ & -417 \\
\hline 31.596794 & 35.557722 & $01 / 05 / 2006$ & -417 \\
\hline 31.596970 & 35.557809 & $01 / 05 / 2006$ & -416 \\
\hline 31.597226 & 35.557929 & $01 / 05 / 2006$ & -417 \\
\hline 31.597117 & 35.557935 & $01 / 05 / 2006$ & -420 \\
\hline 31.597275 & 35.558001 & $01 / 05 / 2006$ & -420 \\
\hline 31.598063 & 35.558760 & $01 / 05 / 2006$ & -420 \\
\hline 31.598127 & 35.558863 & $01 / 05 / 2006$ & -413 \\
\hline 31.598142 & 35.558870 & $01 / 05 / 2006$ & -417 \\
\hline 31.598792 & 35.559631 & $01 / 05 / 2006$ & -417 \\
\hline 31.598940 & 35.559778 & $01 / 05 / 2006$ & -417 \\
\hline 31.599328 & 35.560042 & $01 / 05 / 2006$ & -417 \\
\hline 31.599356 & 35.560058 & $01 / 05 / 2006$ & -418 \\
\hline 31.599369 & 35.560063 & $01 / 05 / 2006$ & -417 \\
\hline 31.599408 & 35.560088 & $01 / 05 / 2006$ & -417 \\
\hline 31.599600 & 35.560240 & $01 / 05 / 2006$ & -416 \\
\hline & & & \\
\hline
\end{tabular}




\begin{tabular}{|c|c|c|c|}
\hline North & East & Date & Elevation (m) \\
\hline 31.599770 & 35.560479 & 01/05/2006 & -414 \\
\hline 31.599776 & 35.560465 & $01 / 05 / 2006$ & -417 \\
\hline 31.599942 & 35.560618 & 01/05/2006 & -417 \\
\hline 31.599997 & 35.560673 & $01 / 05 / 2006$ & -421 \\
\hline 31.600011 & 35.560661 & $01 / 05 / 2006$ & -416 \\
\hline 31.599960 & 35.560473 & 01/05/2006 & -416 \\
\hline 31.599942 & 35.560423 & 01/05/2006 & -416 \\
\hline 31.600221 & 35.560786 & 01/05/2006 & -416 \\
\hline 31.600266 & 35.560798 & 01/05/2006 & -415 \\
\hline 31.600344 & 35.560808 & $01 / 05 / 2006$ & -415 \\
\hline 31.600560 & 35.560869 & 01/05/2006 & -415 \\
\hline 31.600561 & 35.560914 & 01/05/2006 & -413 \\
\hline 31.600556 & 35.561004 & $01 / 05 / 2006$ & -415 \\
\hline 31.600538 & 35.561064 & 01/05/2006 & -415 \\
\hline 31.600486 & 35.561195 & $01 / 05 / 2006$ & -416 \\
\hline 31.600610 & 35.561173 & 01/05/2006 & -416 \\
\hline 31.600613 & 35.560966 & $01 / 05 / 2006$ & -409 \\
\hline 31.600611 & 35.560974 & 01/05/2006 & -410 \\
\hline 31.600660 & 35.560953 & 01/05/2006 & -409 \\
\hline 31.600757 & 35.560917 & 01/05/2006 & -415 \\
\hline 31.600787 & 35.560882 & 01/05/2006 & -413 \\
\hline 31.600821 & 35.560867 & 01/05/2006 & -414 \\
\hline 31.601188 & 35.561018 & 01/05/2006 & -420 \\
\hline 31.601164 & 35.561044 & 01/05/2006 & -421 \\
\hline 31.601180 & 35.561045 & 01/05/2006 & -420 \\
\hline 31.601417 & 35.561168 & 01/05/2006 & -418 \\
\hline 31.601566 & 35.561262 & 01/05/2006 & -418 \\
\hline 31.601665 & 35.561317 & 01/05/2006 & -419 \\
\hline 31.601835 & 35.561488 & 01/05/2006 & -416 \\
\hline 31.602009 & 35.561545 & 01/05/2006 & -414 \\
\hline 31.602029 & 35.561546 & $01 / 05 / 2006$ & -415 \\
\hline 31.602162 & 35.561599 & 01/05/2006 & -417 \\
\hline 31.602259 & 35.561640 & 01/05/2006 & -416 \\
\hline 31.602285 & 35.561681 & 01/05/2006 & -415 \\
\hline 31.602328 & 35.561739 & 01/05/2006 & -416 \\
\hline 31.602767 & 35.561733 & 01/05/2006 & -406 \\
\hline 31.602834 & 35.561682 & 01/05/2006 & -416 \\
\hline 31.602939 & 35.561667 & 01/05/2006 & -415 \\
\hline 31.603173 & 35.561571 & 01/05/2006 & -412 \\
\hline 31.603441 & 35.561490 & 01/05/2006 & -409 \\
\hline 31.603521 & 35.561417 & 01/05/2006 & -410 \\
\hline 31.603720 & 35.561330 & 01/05/2006 & -413 \\
\hline 31.603835 & 35.561337 & 01/05/2006 & -411 \\
\hline 31.603936 & 35.561352 & $01 / 05 / 2006$ & -413 \\
\hline 31.604033 & 35.561366 & 01/05/2006 & -413 \\
\hline 31.604253 & 35.561321 & 01/05/2006 & -413 \\
\hline 31.604384 & 35.561320 & $01 / 05 / 2006$ & -411 \\
\hline 31.604620 & 35.561379 & 01/05/2006 & -411 \\
\hline 31.604797 & 35.561473 & 01/05/2006 & -411 \\
\hline 31.604873 & 35.561527 & 01/05/2006 & -410 \\
\hline 31.604899 & 35.561557 & 01/05/2006 & -412 \\
\hline 31.605019 & 35.561618 & 01/05/2006 & -413 \\
\hline 31.605284 & 35.561705 & 01/05/2006 & -414 \\
\hline 31.605458 & 35.561752 & 01/05/2006 & -410 \\
\hline 31.605491 & 35.561765 & 01/05/2006 & -413 \\
\hline 31.605567 & 35.561790 & $01 / 05 / 2006$ & -410 \\
\hline 31.605616 & 35.561794 & $01 / 05 / 2006$ & -414 \\
\hline
\end{tabular}


North East Date Elevation (m)

\begin{tabular}{|c|c|c|c|}
\hline 31.605756 & 35.561949 & $01 / 05 / 2006$ & -415 \\
\hline 31.605735 & 35.562040 & $01 / 05 / 2006$ & -400 \\
\hline 31.605799 & 35.561968 & $01 / 05 / 2006$ & -417 \\
\hline 31.605556 & 35.562099 & $01 / 05 / 2006$ & -415 \\
\hline 31.605788 & 35.561907 & $01 / 05 / 2006$ & -415 \\
\hline 31.605541 & 35.561818 & $01 / 05 / 2006$ & -409 \\
\hline 31.605455 & 35.561759 & $01 / 05 / 2006$ & -409 \\
\hline 31.605185 & 35.561722 & $01 / 05 / 2006$ & -409 \\
\hline 31.605270 & 35.561758 & $01 / 05 / 2006$ & -416 \\
\hline 31.460011 & 35.571362 & $01 / 07 / 2006$ & -402 \\
\hline 31.459997 & 35.571324 & $01 / 07 / 2006$ & -414 \\
\hline 31.460003 & 35.571328 & 01/07/2006 & -411 \\
\hline 31.460006 & 35.571361 & $01 / 07 / 2006$ & -413 \\
\hline 31.460033 & 35.571440 & $01 / 07 / 2006$ & -417 \\
\hline 31.460159 & 35.571238 & 01/07/2006 & -405 \\
\hline 31.460278 & 35.571184 & 01/07/2006 & -404 \\
\hline 31.460407 & 35.571090 & 01/07/2006 & -405 \\
\hline 31.460566 & 35.571000 & 01/07/2006 & -410 \\
\hline 31.460791 & 35.570771 & 01/07/2006 & -409 \\
\hline 31.461149 & 35.570362 & 01/07/2006 & -410 \\
\hline 31.461425 & 35.569946 & $01 / 07 / 2006$ & -406 \\
\hline 31.461599 & 35.569457 & 01/07/2006 & -407 \\
\hline 31.461603 & 35.569432 & 01/07/2006 & -408 \\
\hline 31.461673 & 35.568822 & $01 / 07 / 2006$ & -406 \\
\hline 31.461703 & 35.568641 & $01 / 07 / 2006$ & -406 \\
\hline 31.461740 & 35.568358 & 01/07/2006 & -408 \\
\hline 31.461854 & 35.567972 & $01 / 07 / 2006$ & -406 \\
\hline 31.462008 & 35.567326 & $01 / 07 / 2006$ & -405 \\
\hline 31.462130 & 35.567004 & 01/07/2006 & -406 \\
\hline 31.462352 & 35.566473 & $01 / 07 / 2006$ & -407 \\
\hline 31.462432 & 35.566379 & $01 / 07 / 2006$ & -414 \\
\hline 31.462523 & 35.566218 & 01/07/2006 & -414 \\
\hline 31.462611 & 35.565977 & $01 / 07 / 2006$ & -413 \\
\hline 31.462746 & 35.565685 & $01 / 07 / 2006$ & -412 \\
\hline 31.462858 & 35.565507 & 01/07/2006 & -410 \\
\hline 31.462892 & 35.565460 & 01/07/2006 & -410 \\
\hline 31.462998 & 35.565299 & $01 / 07 / 2006$ & -413 \\
\hline 31.463397 & 35.564814 & $01 / 07 / 2006$ & -411 \\
\hline 31.463618 & 35.564624 & 01/07/2006 & -413 \\
\hline 31.463769 & 35.564486 & 01/07/2006 & -412 \\
\hline 31.464073 & 35.564189 & $01 / 07 / 2006$ & -412 \\
\hline 31.464390 & 35.563874 & 01/07/2006 & -413 \\
\hline 31.464650 & 35.563603 & 01/07/2006 & -411 \\
\hline 31.464655 & 35.563590 & $01 / 07 / 2006$ & -411 \\
\hline 31.464821 & 35.563593 & $01 / 07 / 2006$ & -413 \\
\hline 31.465324 & 35.563228 & 01/07/2006 & -409 \\
\hline 31.465691 & 35.562979 & 01/07/2006 & -411 \\
\hline 31.466106 & 35.562742 & $01 / 07 / 2006$ & -402 \\
\hline 31.466232 & 35.562794 & 01/07/2006 & -413 \\
\hline 31.466385 & 35.562818 & 01/07/2006 & -412 \\
\hline 31.467003 & 35.563270 & $01 / 07 / 2006$ & -412 \\
\hline 31.467031 & 35.563288 & 01/07/2006 & -412 \\
\hline 31.467137 & 35.563397 & 01/07/2006 & -415 \\
\hline 31.467098 & 35.563440 & 01/07/2006 & -417 \\
\hline 31.467096 & 35.563504 & 01/07/2006 & -418 \\
\hline
\end{tabular}




\begin{tabular}{|c|c|c|c|}
\hline North & East & Date & vation $(\mathrm{m})$ \\
\hline 31.467221 & 35.563612 & $01 / 07 / 2006$ & -417 \\
\hline 31.467517 & 35.563738 & 01/07/2006 & -417 \\
\hline 31.468053 & 35.563852 & 01/07/2006 & -417 \\
\hline 31.468622 & 35.564010 & $01 / 07 / 2006$ & -418 \\
\hline 31.468770 & 35.564128 & 01/07/2006 & -418 \\
\hline 31.468930 & 35.564330 & $01 / 07 / 2006$ & -418 \\
\hline 31.469100 & 35.564505 & 01/07/2006 & -418 \\
\hline 31.469362 & 35.564714 & 01/07/2006 & -416 \\
\hline 31.469472 & 35.564861 & 01/07/2006 & -416 \\
\hline 31.469502 & 35.564896 & 01/07/2006 & -416 \\
\hline 31.469626 & 35.565078 & $01 / 07 / 2006$ & -417 \\
\hline 31.469719 & 35.565296 & $01 / 07 / 2006$ & -417 \\
\hline 31.469741 & 35.565335 & 01/07/2006 & -417 \\
\hline 31.469776 & 35.565494 & 01/07/2006 & -418 \\
\hline 31.469835 & 35.565656 & 01/07/2006 & -417 \\
\hline 31.469860 & 35.565792 & 01/07/2006 & -415 \\
\hline 31.470045 & 35.566219 & $01 / 07 / 2006$ & -415 \\
\hline 31.470163 & 35.566419 & 01/07/2006 & -415 \\
\hline 31.470186 & 35.566452 & 01/07/2006 & -416 \\
\hline 31.470260 & 35.566602 & 01/07/2006 & -416 \\
\hline 31.470386 & 35.566862 & 01/07/2006 & -416 \\
\hline 31.470557 & 35.567308 & $01 / 07 / 2006$ & -416 \\
\hline 31.470659 & 35.567578 & 01/07/2006 & -415 \\
\hline 31.470673 & 35.567788 & 01/07/2006 & -416 \\
\hline 31.470667 & 35.567976 & 01/07/2006 & -418 \\
\hline 31.470669 & 35.568292 & 01/07/2006 & -418 \\
\hline 31.470679 & 35.568427 & $01 / 07 / 2006$ & -419 \\
\hline 31.470752 & 35.568718 & 01/07/2006 & -419 \\
\hline 31.470785 & 35.568912 & 01/07/2006 & -419 \\
\hline 31.470834 & 35.569241 & 01/07/2006 & -419 \\
\hline 31.470747 & 35.569615 & 01/07/2006 & -421 \\
\hline 31.470734 & 35.569947 & 01/07/2006 & -422 \\
\hline 31.470790 & 35.570305 & 01/07/2006 & -420 \\
\hline 31.470804 & 35.570601 & 01/07/2006 & -419 \\
\hline 31.470829 & 35.570658 & 01/07/2006 & -419 \\
\hline 31.470828 & 35.570786 & 01/07/2006 & -416 \\
\hline 31.470820 & 35.571202 & 01/07/2006 & -414 \\
\hline 31.470784 & 35.571630 & 01/07/2006 & -416 \\
\hline 31.470777 & 35.571856 & 01/07/2006 & -418 \\
\hline 31.470860 & 35.572145 & 01/07/2006 & -418 \\
\hline 31.470971 & 35.572521 & 01/07/2006 & -417 \\
\hline 31.471204 & 35.573030 & 01/07/2006 & -417 \\
\hline 31.471298 & 35.573231 & 01/07/2006 & -416 \\
\hline 31.471425 & 35.573441 & 01/07/2006 & -415 \\
\hline 31.471528 & 35.573624 & 01/07/2006 & -415 \\
\hline 31.471623 & 35.573784 & $01 / 07 / 2006$ & -415 \\
\hline 31.471737 & 35.574013 & 01/07/2006 & -413 \\
\hline 31.471695 & 35.574111 & 01/07/2006 & -402 \\
\hline 31.471702 & 35.574028 & 01/07/2006 & -415 \\
\hline 31.448243 & 35.565469 & $01 / 07 / 2006$ & -420 \\
\hline 31.448111 & 35.565496 & 01/07/2006 & -420 \\
\hline 31.448091 & 35.565506 & 01/07/2006 & -410 \\
\hline 31.448172 & 35.565468 & 01/07/2006 & -420 \\
\hline 31.448384 & 35.565265 & 01/07/2006 & -420 \\
\hline 31.448428 & 35.565203 & 01/07/2006 & -420 \\
\hline 31.448510 & 35.565108 & 01/07/2006 & -420 \\
\hline 31.448637 & 56 & 01 & \\
\hline
\end{tabular}




\begin{tabular}{|c|c|c|c|}
\hline North & East & Date & Elevation(m) \\
\hline 31.448721 & 35.564902 & $01 / 07 / 2006$ & -420 \\
\hline 31.448748 & 35.564885 & $01 / 07 / 2006$ & -420 \\
\hline 31.449018 & 35.564640 & $01 / 07 / 2006$ & -420 \\
\hline 31.449212 & 35.564466 & $01 / 07 / 2006$ & -420 \\
\hline 31.449450 & 35.564313 & $01 / 07 / 2006$ & -420 \\
\hline 31.449745 & 35.564229 & $01 / 07 / 2006$ & -420 \\
\hline 31.450075 & 35.564092 & $01 / 07 / 2006$ & -420 \\
\hline 31.450173 & 35.564002 & $01 / 07 / 2006$ & -420 \\
\hline 31.450353 & 35.563888 & $01 / 07 / 2006$ & -420 \\
\hline 31.450357 & 35.563884 & $01 / 07 / 2006$ & -420 \\
\hline 31.450730 & 35.563689 & $01 / 07 / 2006$ & -420 \\
\hline 31.450742 & 35.563711 & $01 / 07 / 2006$ & -420 \\
\hline 31.450925 & 35.563644 & $01 / 07 / 2006$ & -419 \\
\hline 31.451086 & 35.563659 & $01 / 07 / 2006$ & -418 \\
\hline 31.451353 & 35.563827 & $01 / 07 / 2006$ & -419 \\
\hline 31.451393 & 35.563885 & $01 / 07 / 2006$ & -419 \\
\hline 31.451555 & 35.564196 & $01 / 07 / 2006$ & -419 \\
\hline 31.451561 & 35.564207 & $01 / 07 / 2006$ & -415 \\
\hline 31.451709 & 35.564348 & $01 / 07 / 2006$ & -416 \\
\hline 31.451950 & 35.564686 & $01 / 07 / 2006$ & -416 \\
\hline 31.452037 & 35.564917 & $01 / 07 / 2006$ & -417 \\
\hline 31.452248 & 35.565140 & $01 / 07 / 2006$ & -419 \\
\hline 31.452533 & 35.565362 & $01 / 07 / 2006$ & -420 \\
\hline 31.452734 & 35.565491 & $01 / 07 / 2006$ & -420 \\
\hline 31.452890 & 35.565585 & $01 / 07 / 2006$ & -420 \\
\hline 31.453098 & 35.565656 & $01 / 07 / 2006$ & -420 \\
\hline 31.453263 & 35.565731 & $01 / 07 / 2006$ & -420 \\
\hline 31.453530 & 35.565841 & $01 / 07 / 2006$ & -420 \\
\hline 31.453691 & 35.565856 & $01 / 07 / 2006$ & -420 \\
\hline 31.453733 & 35.565902 & $01 / 07 / 2006$ & -420 \\
\hline 31.454165 & 35.565941 & $01 / 07 / 2006$ & -420 \\
\hline 31.454404 & 35.565746 & $01 / 07 / 2006$ & -420 \\
\hline 31.454427 & 35.565693 & $01 / 07 / 2006$ & -420 \\
\hline 31.454544 & 35.565697 & $01 / 07 / 2006$ & -420 \\
\hline 31.454767 & 35.565957 & $01 / 07 / 2006$ & -420 \\
\hline 31.454945 & 35.566070 & $01 / 07 / 2006$ & -420 \\
\hline 31.454989 & 35.566134 & $01 / 07 / 2006$ & -420 \\
\hline 31.455087 & 35.566294 & $01 / 07 / 2006$ & -420 \\
\hline 31.455179 & 35.566486 & $01 / 07 / 2006$ & -418 \\
\hline 31.455325 & 35.566739 & $01 / 07 / 2006$ & -419 \\
\hline 31.455430 & 35.566963 & $01 / 07 / 2006$ & -419 \\
\hline 31.455504 & 35.567070 & $01 / 07 / 2006$ & -420 \\
\hline 31.455636 & 35.567226 & $01 / 07 / 2006$ & -419 \\
\hline 31.455721 & 35.567307 & $01 / 07 / 2006$ & -420 \\
\hline 31.455743 & 35.567437 & $01 / 07 / 2006$ & -419 \\
\hline 31.455979 & 35.567692 & $01 / 07 / 2006$ & -420 \\
\hline 31.456072 & 35.567767 & $01 / 07 / 2006$ & -420 \\
\hline 31.456151 & 35.567855 & $01 / 07 / 2006$ & -420 \\
\hline 31.456295 & 35.568024 & $01 / 07 / 2006$ & -420 \\
\hline 31.456375 & 35.568177 & $01 / 07 / 2006$ & -420 \\
\hline 31.456512 & 35.568266 & $01 / 07 / 2006$ & -420 \\
\hline 31.456627 & 35.568467 & $01 / 07 / 2006$ & -420 \\
\hline 31.456639 & 35.568549 & $01 / 07 / 2006$ & -420 \\
\hline 31.456700 & 35.568796 & $01 / 07 / 2006$ & -420 \\
\hline 31.456786 & 35.569036 & $01 / 07 / 2006$ & -420 \\
\hline 31.456825 & 35.569203 & $01 / 07 / 2006$ & -420 \\
\hline 31.456834 & 35.569280 & $01 / 07 / 2006$ & -420 \\
\hline
\end{tabular}




\begin{tabular}{llll} 
North & East & Date & Elevation(m) \\
\hline 31.456837 & 35.569360 & $01 / 07 / 2006$ & -420 \\
31.456868 & 35.569432 & $01 / 07 / 2006$ & -420 \\
31.457027 & 35.569652 & $01 / 07 / 2006$ & -420 \\
31.457058 & 35.569695 & $01 / 07 / 2006$ & -420 \\
31.457329 & 35.570068 & $01 / 07 / 2006$ & -420 \\
31.457462 & 35.570245 & $01 / 07 / 2006$ & -420 \\
31.457488 & 35.570263 & $01 / 07 / 2006$ & -420 \\
31.457563 & 35.570368 & $01 / 07 / 2006$ & -420 \\
31.457719 & 35.570658 & $01 / 07 / 2006$ & -420 \\
31.457754 & 35.570715 & $01 / 07 / 2006$ & -417 \\
31.457937 & 35.570871 & $01 / 07 / 2006$ & -415 \\
31.457961 & 35.570936 & $01 / 07 / 2006$ & -418 \\
31.458012 & 35.570979 & $01 / 07 / 2006$ & -417 \\
31.458230 & 35.571077 & $01 / 07 / 2006$ & -417 \\
31.458433 & 35.571136 & $01 / 07 / 2006$ & -417 \\
31.458488 & 35.571166 & $01 / 07 / 2006$ & -416 \\
31.458476 & 35.571200 & $01 / 07 / 2006$ & -420 \\
& & & \\
31.816396 & 35.647351 & $01 / 13 / 2006$ & -418 \\
31.816315 & 35.647422 & $01 / 13 / 2006$ & -418 \\
31.693579 & 35.579533 & $01 / 13 / 2006$ & -416 \\
31.693504 & 35.579647 & $01 / 13 / 2006$ & -416 \\
31.693501 & 35.579712 & $01 / 13 / 2006$ & -420 \\
31.693471 & 35.579783 & $01 / 13 / 2006$ & -420 \\
31.693457 & 35.579804 & $01 / 13 / 2006$ & -420 \\
31.693475 & 35.579893 & $01 / 13 / 2006$ & -420 \\
31.693475 & 35.579910 & $01 / 13 / 2006$ & -420 \\
31.693613 & 35.579946 & $01 / 13 / 2006$ & -420 \\
31.693646 & 35.579954 & $01 / 13 / 2006$ & -420 \\
31.693747 & 35.579981 & $01 / 13 / 2006$ & -416 \\
31.693925 & 35.580017 & $01 / 13 / 2006$ & -417 \\
31.694147 & 35.580056 & $01 / 13 / 2006$ & -418 \\
31.694330 & 35.580145 & $01 / 13 / 2006$ & -418 \\
31.694602 & 35.580243 & $01 / 13 / 2006$ & -418 \\
31.694774 & 35.580307 & $01 / 13 / 2006$ & -417 \\
31.694985 & 35.580381 & $01 / 13 / 2006$ & -418 \\
31.695296 & 35.580472 & $01 / 13 / 2006$ & -417 \\
31.695443 & 35.580484 & $01 / 13 / 2006$ & -417 \\
31.695633 & 35.580452 & $01 / 13 / 2006$ & -418 \\
31.695856 & 35.580489 & $01 / 13 / 2006$ & -418 \\
31.696097 & 35.580553 & $01 / 13 / 2006$ & -417 \\
31.696140 & 35.580571 & $01 / 13 / 2006$ & -417 \\
31.696352 & 35.580651 & $01 / 13 / 2006$ & -416 \\
31.696522 & 35.580677 & $01 / 13 / 2006$ & -414 \\
31.696513 & 35.580663 & $01 / 13 / 2006$ & -416 \\
31.696644 & 35.580653 & $01 / 13 / 2006$ & -416 \\
31.696840 & 35.580692 & $01 / 13 / 2006$ & -414 \\
31.697022 & 35.580698 & $01 / 13 / 2006$ & -416 \\
31.697500 & 35.580781 & $01 / 13 / 2006$ & -418 \\
31.697704 & 35.580885 & $01 / 13 / 2006$ & -418 \\
31.697717 & 35.580896 & $01 / 13 / 2006$ & -416 \\
31.697895 & 35.580956 & $01 / 13 / 2006$ & -418 \\
31.698418 & 35.580992 & $01 / 13 / 2006$ & -419 \\
31.698892 & 35.581024 & $01 / 13 / 2006$ & -421 \\
31.699298 & 35.581100 & $01 / 13 / 2006$ & -420 \\
& & &
\end{tabular}




\begin{tabular}{|c|c|c|c|}
\hline North & East & Date & vation (m) \\
\hline 31.699623 & 35.581330 & $01 / 13 / 2006$ & -419 \\
\hline 31.699838 & 35.581492 & $01 / 13 / 2006$ & -417 \\
\hline 31.700033 & 35.581628 & $01 / 13 / 2006$ & -417 \\
\hline 31.700150 & 35.581724 & $01 / 13 / 2006$ & -416 \\
\hline 31.700224 & 35.581845 & $01 / 13 / 2006$ & -417 \\
\hline 31.700315 & 35.581954 & $01 / 13 / 2006$ & -417 \\
\hline 31.700330 & 35.582006 & $01 / 13 / 2006$ & -417 \\
\hline 31.700260 & 35.582037 & $01 / 13 / 2006$ & -418 \\
\hline 31.700363 & 35.582169 & $01 / 13 / 2006$ & -417 \\
\hline 31.700371 & 35.582174 & $01 / 13 / 2006$ & -416 \\
\hline 31.700094 & 35.582214 & $01 / 13 / 2006$ & -412 \\
\hline 31.700104 & 35.582214 & 01/13/2006 & -412 \\
\hline 31.700432 & 35.582256 & $01 / 13 / 2006$ & -418 \\
\hline 31.700527 & 35.582204 & 01/13/2006 & -419 \\
\hline 31.700534 & 35.582104 & $01 / 13 / 2006$ & -421 \\
\hline 31.700558 & 35.582115 & $01 / 13 / 2006$ & -421 \\
\hline 31.700883 & 35.582370 & $01 / 13 / 2006$ & -417 \\
\hline 31.700973 & 35.582452 & $01 / 13 / 2006$ & -417 \\
\hline 31.701235 & 35.582629 & $01 / 13 / 2006$ & -416 \\
\hline 31.701622 & 35.582960 & 01/13/2006 & -413 \\
\hline 31.701928 & 35.583147 & $01 / 13 / 2006$ & -413 \\
\hline 31.702141 & 35.583288 & 01/13/2006 & -415 \\
\hline 31.702375 & 35.583385 & 01/13/2006 & -414 \\
\hline 31.702437 & 35.583383 & $01 / 13 / 2006$ & -414 \\
\hline 31.702514 & 35.583367 & $01 / 13 / 2006$ & -414 \\
\hline 31.702929 & 35.583407 & 01/13/2006 & -415 \\
\hline 31.703206 & 35.583343 & 01/13/2006 & -417 \\
\hline 31.703493 & 35.583200 & $01 / 13 / 2006$ & -418 \\
\hline 31.703561 & 35.583100 & $01 / 13 / 2006$ & -418 \\
\hline 31.703879 & 35.582897 & 01/13/2006 & -417 \\
\hline 31.703971 & 35.582878 & $01 / 13 / 2006$ & -418 \\
\hline 31.704087 & 35.582935 & 01/13/2006 & -421 \\
\hline 31.704230 & 35.582863 & $01 / 13 / 2006$ & -421 \\
\hline 31.704326 & 35.582875 & $01 / 13 / 2006$ & -420 \\
\hline 31.704390 & 35.582934 & 01/13/2006 & -420 \\
\hline 31.704547 & 35.582954 & 01/13/2006 & -420 \\
\hline 31.704895 & 35.582865 & 01/13/2006 & -420 \\
\hline 31.705144 & 35.582794 & $01 / 13 / 2006$ & -420 \\
\hline 31.705286 & 35.582742 & $01 / 13 / 2006$ & -420 \\
\hline 31.705491 & 35.582680 & 01/13/2006 & -420 \\
\hline 31.705843 & 35.582618 & 01/13/2006 & -420 \\
\hline 31.706150 & 35.582557 & $01 / 13 / 2006$ & -420 \\
\hline 31.706321 & 35.582443 & 01/13/2006 & -420 \\
\hline 31.706582 & 35.582324 & $01 / 13 / 2006$ & -420 \\
\hline 31.706925 & 35.582216 & 01/13/2006 & -420 \\
\hline 31.707207 & 35.582201 & 01/13/2006 & -418 \\
\hline 31.707348 & 35.582197 & $01 / 13 / 2006$ & -420 \\
\hline 31.707520 & 35.582270 & $01 / 13 / 2006$ & -420 \\
\hline 31.707670 & 35.582420 & 01/13/2006 & -420 \\
\hline 31.707723 & 35.582492 & 01/13/2006 & -420 \\
\hline 31.707764 & 35.582533 & $01 / 13 / 2006$ & -420 \\
\hline 31.708117 & 35.582770 & 01/13/2006 & -420 \\
\hline 31.708327 & 35.582818 & 01/13/2006 & -420 \\
\hline 31.708517 & 35.582879 & $01 / 13 / 2006$ & -420 \\
\hline 31.708672 & 35.582901 & $01 / 13 / 2006$ & -419 \\
\hline 31.708855 & 35.582926 & 01/13/2006 & -419 \\
\hline 31.709130 & 35.582936 & 01/13/2006 & -420 \\
\hline
\end{tabular}




\begin{tabular}{|c|c|c|c|}
\hline North & East & Date & evation (m) \\
\hline 31.709266 & 35.582973 & $01 / 13 / 2006$ & -420 \\
\hline 31.709430 & 35.583039 & $01 / 13 / 2006$ & -420 \\
\hline 31.709736 & 35.583181 & $01 / 13 / 2006$ & -420 \\
\hline 31.709798 & 35.583220 & $01 / 13 / 2006$ & -420 \\
\hline 31.709957 & 35.583313 & $01 / 13 / 2006$ & -420 \\
\hline 31.710096 & 35.583384 & $01 / 13 / 2006$ & -420 \\
\hline 31.710184 & 35.583451 & $01 / 13 / 2006$ & -420 \\
\hline 31.710285 & 35.583486 & $01 / 13 / 2006$ & -420 \\
\hline 31.710601 & 35.583658 & $01 / 13 / 2006$ & -420 \\
\hline 31.710639 & 35.583682 & $01 / 13 / 2006$ & -420 \\
\hline 31.711041 & 35.583746 & 01/13/2006 & -420 \\
\hline 31.711048 & 35.583731 & $01 / 13 / 2006$ & -420 \\
\hline 31.711188 & 35.583776 & $01 / 13 / 2006$ & -419 \\
\hline 31.711371 & 35.583907 & 01/13/2006 & -418 \\
\hline 31.711586 & 35.584048 & $01 / 13 / 2006$ & -416 \\
\hline 31.711753 & 35.584134 & $01 / 13 / 2006$ & -418 \\
\hline 31.712005 & 35.584325 & $01 / 13 / 2006$ & -419 \\
\hline 31.712282 & 35.584433 & $01 / 13 / 2006$ & -420 \\
\hline 31.712519 & 35.584644 & $01 / 13 / 2006$ & -420 \\
\hline 31.712804 & 35.584754 & 01/13/2006 & -420 \\
\hline 31.713149 & 35.584666 & $01 / 13 / 2006$ & -419 \\
\hline 31.713568 & 35.584568 & 01/13/2006 & -420 \\
\hline 31.713837 & 35.584537 & $01 / 13 / 2006$ & -420 \\
\hline 31.713861 & 35.584552 & $01 / 13 / 2006$ & -420 \\
\hline 31.714005 & 35.584538 & $01 / 13 / 2006$ & -420 \\
\hline 31.714073 & 35.584533 & $01 / 13 / 2006$ & -420 \\
\hline 31.714172 & 35.584459 & 01/13/2006 & -419 \\
\hline 31.714425 & 35.584282 & 01/13/2006 & -420 \\
\hline 31.714848 & 35.584005 & $01 / 13 / 2006$ & -419 \\
\hline 31.715344 & 35.583883 & 01/13/2006 & -420 \\
\hline 31.715888 & 35.583716 & 01/13/2006 & -420 \\
\hline 31.716273 & 35.583616 & 01/13/2006 & -420 \\
\hline 31.716280 & 35.583611 & $01 / 13 / 2006$ & -420 \\
\hline 31.716308 & 35.583533 & 01/13/2006 & -420 \\
\hline 31.716459 & 35.583395 & 01/13/2006 & -420 \\
\hline 31.716612 & 35.583343 & $01 / 13 / 2006$ & -420 \\
\hline 31.716959 & 35.583282 & 01/13/2006 & -420 \\
\hline 31.717240 & 35.583268 & $01 / 13 / 2006$ & -420 \\
\hline 31.717293 & 35.583235 & $01 / 13 / 2006$ & -420 \\
\hline 31.717536 & 35.583293 & 01/13/2006 & -420 \\
\hline 31.717858 & 35.583315 & $01 / 13 / 2006$ & -420 \\
\hline 31.717982 & 35.583283 & $01 / 13 / 2006$ & -420 \\
\hline 31.718254 & 35.583225 & 01/13/2006 & -420 \\
\hline 31.718560 & 35.583241 & $01 / 13 / 2006$ & -420 \\
\hline 31.718586 & 35.583251 & 01/13/2006 & -420 \\
\hline 31.718701 & 35.583375 & $01 / 13 / 2006$ & -420 \\
\hline 31.718897 & 35.583603 & $01 / 13 / 2006$ & -420 \\
\hline 31.719099 & 35.583785 & 01/13/2006 & -420 \\
\hline 31.719222 & 35.583878 & $01 / 13 / 2006$ & -419 \\
\hline 31.719295 & 35.583925 & 01/13/2006 & -420 \\
\hline 31.719457 & 35.584015 & $01 / 13 / 2006$ & -420 \\
\hline 31.719464 & 35.584059 & $01 / 13 / 2006$ & -420 \\
\hline 31.719619 & 35.584075 & 01/13/2006 & -420 \\
\hline 31.719725 & 35.584170 & $01 / 13 / 2006$ & -420 \\
\hline 31.719819 & 35.584238 & $01 / 13 / 2006$ & -420 \\
\hline 31.719920 & 35.584364 & 01/13/2006 & -420 \\
\hline 31.720122 & 35.584540 & $01 / 13 / 2006$ & -420 \\
\hline
\end{tabular}




\begin{tabular}{llll} 
North & East & Date & Elevation $(\mathrm{m})$ \\
\hline 31.720424 & 35.584696 & $01 / 13 / 2006$ & -420 \\
31.720521 & 35.584750 & $01 / 13 / 2006$ & -420 \\
31.720751 & 35.584871 & $01 / 13 / 2006$ & -420 \\
31.720918 & 35.585056 & $01 / 13 / 2006$ & -420 \\
31.721152 & 35.585244 & $01 / 13 / 2006$ & -420 \\
31.721454 & 35.585227 & $01 / 13 / 2006$ & -420 \\
31.721678 & 35.585271 & $01 / 13 / 2006$ & -420 \\
31.721827 & 35.585252 & $01 / 13 / 2006$ & -420 \\
31.721906 & 35.585311 & $01 / 13 / 2006$ & -419 \\
31.722093 & 35.585481 & $01 / 13 / 2006$ & -420 \\
31.722179 & 35.585546 & $01 / 13 / 2006$ & -418 \\
31.721952 & 35.585505 & $01 / 13 / 2006$ & -420 \\
31.722078 & 35.585549 & $01 / 13 / 2006$ & -420
\end{tabular}




\section{Curriculum Vitae of the Author}

Emad Akawwi was born on February 02, 1966 in Al Fuhais, in Jordan. He was obtained his General Secondary Certificate (Tawjihi)-Scientific Stream in 1984 from Al Fuhais secondary school. In this year he began to attend the Earth and Environmental Department-Al Yarmouk University-Irbid, Jordan and he was awarded a B.Sc. Degree in 1988.

He has working at Natural Resources Authority from 1989 until now. During these years he got a study leave on Oct.1997 and he attend the Faculty of Graduate Studies-Cardiff University-Wales, UK. He was awarded a Master of Science in Geotechnical Engineering in March 2000.

From 2003 to 2006 he was a Ph.D. student at the University of Goettingen, Germany, Department of Applied Geology.

The addresses of the author are:

Postal address: Al Fuhais- P. O. Box 27

Postal code 19152/ Jordan.

E-mail : ejeakawwi@hotmail.com. 